UNIVERSIDADE DE SÃO PAULO

FACULDADE DE FILOSOFIA, LETRAS E CIÊNCIAS HUMANAS DEPARTAMENTO DE GEOGRAFIA PROGRAMA DE PÓS-GRADUAÇÃO EM GEOGRAFIA HUMANA

\author{
EVANDRO ANDAKU \\ Orientador: Francisco Capuano Scarlato
}

\title{
AS MARCAS E PATENTES NA REPRODUÇÃO DO ESPAÇO DESIGUAL: ESTADOS UNIDOS E CHINA
}

\author{
Versão Corrigida
}

SÃO PAULO - SP

2021 
UNIVERSIDADE DE SÃO PAULO

FACULDADE DE FILOSOFIA, LETRAS E CIÊNCIAS HUMANAS

DEPARTAMENTO DE GEOGRAFIA

PROGRAMA DE PÓS-GRADUAÇÃO EM GEOGRAFIA

HUMANA

EVANDRO ANDAKU

Orientador: Francisco Capuano Scarlato

\section{AS MARCAS E PATENTES NA REPRODUÇÃO DO ESPAÇO DESIGUAL: ESTADOS UNIDOS E CHINA}

Versão Corrigida

Tese apresentada ao Departamento de Geografia da Faculdade de Filosofia, Letras e Ciências Humanas da Universidade de São Paulo para obtenção do título de Doutor em Geografia Humana

SÃO PAULO - SP

2021 
Catalogação na Publicação

Serviço de Biblioteca e Documentação

Faculdade de Filosofia, Letras e Ciências Humanas da Universidade de São Paulo

Andaku, Evandro

As marcas e patentes na reprodução do espaço desigual:

Estados Unidos e China/ Evandro Andaku; orientador Francisco

Capuano Scarlato. São Paulo, 2021.

$195 \mathrm{f}$.

Tese (Doutorado_ - Faculdade de Filosofia, Letras e Ciências Humanas da Universidade de São Paulo. Departamento de Geografia. Área de concentração: Geografia Humana.

1. Marcas. 2. Patentes de invenção. 3. Desenvolvimento desigual. 4. Estados Unidos. 5. China. 


\title{
ENTREGA DO EXEMPLAR CORRIGIDO DA TESE
}

Termo de Ciência e Concordância do orientador

\author{
Aluno: Evandro Andaku \\ Data da defesa: 22/03/2021 \\ Professor Orientador: Francisco Capuano Scarlato
}

Nos termos da legislação vigente, declaro ESTAR CIENTE do conteúdo deste EXEMPLAR CORRIGIDO elaborado em atenção às sugestões dos membros da comissão Julgadora na sessão de defesa do trabalho, manifestando-me plenamente favorável ao seu encaminhamento e publicação no Portal Digital de Teses da USP.

São Paulo, 21/05/2021 
Andaku, Evandro. As marcas e patentes na reprodução do espaço desigual. Estados Unidos

e China. Tese (Doutorado em Geografia Humana) - Faculdade de Filosofia, Letras e Ciências Humanas, Universidade de São Paulo, São Paulo, 2021.

Aprovada em: 22 de março de 2021

\section{Banca Examinadora}

Profa. Dra. Gloria da Anunciação Alves

Universidade de São Paulo

Prof. Dr. Andre Roberto Martin

Universidade de São Paulo

Prof. Dr. Elias Marco Khalil Jabbour

Universidade Estadual do Rio de Janeiro

Prof. Dr. Ricardo Abid Castilho

Universidade Estadual de Campinas 
Este trabalho é dedicado a Armen Mamigonian, Francisco Capuano Scarlato, aos professores e pesquisadores que continuam a fazer ciência no Brasil e à memória do Professor Yukio Andaku, meu saudoso pai, que dedicou a sua vida à

Educação. 


\section{Agradecimentos}

Em primeiro lugar ao Professor Francisco Capuano Scarlato, orientador, amigo, conselheiro, pessoa culta e diligente, que emprestou apoio fundamental para a realização desta tese. Ao Professor Armem Mamigonian, orientador no Mestrado, amigo, conselheiro, pesquisador visionário, portador de conhecimento enciclopédico, que me fez voltar à vida acadêmica na Universidade de São Paulo, após 15 anos. Foram para mim verdadeiros mestres, no acolhimento, no aconselhamento e direcionamento das pesquisas.

Ao Professor André Martin, que me acolheu como estagiário no Programa de Aperfeiçoamento do Ensino, atuou na banca de qualificação e com quem passei boas tardes de longas conversas. Aos Professores do Departamento de Geografia, Marta Medeiros e Gloria da Anunciação Alves, professores de disciplinas cursadas e Monica Arroyo pelas orientações durante as pesquisas e durante a banca de qualificação.

Aos demais membros da banca, Elias Jabbour e Ricardo Castilho. Com Elias aprendi muito sobre economia política e China nas muitas aulas e palestras assistidas. Com Ricardo muito aprendi sobre o rigor do método e sobre a obra do Professor Milton Santos.

A todos os pesquisadores e pesquisadoras membros do Laboratório de Geografia Política e Planejamento Territorial e Ambiental da Universidade de São Paulo (Laboplan) e Ana Elisa Pereira, pelo apoio constante. Um agradecimento especial a Pedro Mezgravis, que me deu a sugestão, já no primeiro ano do doutorado sobre o modo como eu deveria estruturar a tese nas três partes definidas: Marcas, Patentes, e a seção dedicada à exploração das potências nas propriedades intelectuais. A Washington Silva, que me orientou e forneceu o material didático na preparação para a prova de conhecimentos específicos durante o processo seletivo do doutorado.

A minha mulher Juliana Reiko Ii Andaku, pelo apoio constante.

A meus familiares, minha mãe Reiko, meus irmãos Miryan, Yves, Regis e Cesar Andaku pelo apoio material e imaterial.

À Capes, pela concessão de bolsa ao projeto que resultou na presente tese. 


\section{RESUMO}

ANDAKU, Evandro. Marcas e Patentes

As marcas e as patentes na reprodução do espaço desigual. Estados Unidos e China. 2021. f. 195 Tese (Doutorado em Geografia Humana) - Departamento de Geografia da Faculdade de Filosofia, Letras e Ciências Humanas da Universidade de São Paulo. São Paulo. 2021.

Nesta tese temos como objetivo inicial demonstrar que os direitos de propriedade intelectual, e mais acentuadamente as marcas e as patentes, se constituem em mecanismos de desenvolvimento desigual que se refletem espacialmente, na medida em que ajudam a criar monopólios de tecnologia e conhecimentos científicos em favor de atores hegemônicos da economia mundial. Trata-se de instrumento de manutenção e aprofundamento da divisão internacional do trabalho. Como segundo objetivo, sustentamos que os Estados Unidos, que tomou a frente da economia mundial a partir do último quarto do Século XIX, seguido posteriormente por Japão e países da Europa Ocidental, com suas empresas, divide hoje a hegemonia econômica e tecnológica com a China, que iniciou seu processo de ascensão 100 anos depois, no último quarto do século XX. Em um contexto de transição, fazemos breve incursão para afirmar que a ascensão e eventual hegemonia chinesa, embora com outra face cultural, apresentará uma geopolítica e uma geoeconomia levemente diferente, uma vez que a China segue o jogo de poder dentro de um mesmo sistema global de unicidade técnica. Utilizamos como método de trabalho a pesquisa analítica dos registros de marcas e patentes junto aos órgãos internacionais, as transações e litígios envolvendo as patentes e as marcas e ainda a ampla leitura de documentos que cuidam dessa ascensão chinesa, mas mais acentuadamente da literatura das últimas décadas, período em que esta ascensão se fez mais visível, sem descartar os clássicos da Geografia e da Economia. Os resultados apresentados confirmam os pressupostos iniciais da pesquisa, com uma conclusão de que a China já exerce um poder significativo a ponto de dizer que já compartilha, no mínimo, da hegemonia americana.

Palavras-chaves: Marcas. Patentes de invenções. Desenvolvimento desigual. Estados Unidos. China. 


\begin{abstract}
ANDAKU, Evandro.

Trademarks and patents on reproduction of uneven space. The United States and China. 2021. 195 p. Tese (Doutorado em Geografia Humana) - Departamento de Geografia da Faculdade de Filosofia, Letras e Ciências Humanas da Universidade de São Paulo. São Paulo. 2021.

On this thesis we have the initial aim to demonstrate that intellectual property rights, and more markedly the trademarks and patents constitute mechanisms of uneven development that is reflected spatially, insofar as they create monopolies of technology and scientific knowledge in favor of hegemonic actors of the world economy. Trademarks and Patents are instruments for the maintenance and deepening of the international division of labour. The second objective, we maintain that the main hegemonic actor, that is the United States, that started its economic power in the last quarter of XIX Century, later followed by Japan and Western Europe Countries with its companies, is being surpassed by China, which started its economic ascension 100 years later. In a transition context, we make a brief incursion to argue that the rise and eventual Chinese hegemony, albeit with another cultural face, will present slightly different geopolitics and geoeconomics, since China plays the same power game within the same global system of technical unity. We use as a method of work the analytical research of trademarks and patents with the international agencies, transactions and litigations involving patents and trademarks and also the ample reading of documents that deal with this Chinese ascent, but more sharply of the literature of the last decades, when this rise becomes more visible, and also classics of Geography and Economy. The presented results confirm the initial assumptions of the research, with a conclusion that China already exerts significant power to the point of saying that it already shares American hegemony.
\end{abstract}

Keywords: Trademarks. Patents. Uneven Development. United States. China. 


\section{RESUMÉ}

Les marques et les brevets sur la reproduction de l'espace inégal. Les États-Unis et la Chine. 2021. 195 f. Thèse (Doctorat en Géographie Humaine) - Département de Géographie de la Faculté de Philosophie, Lettres et Sciences Humaines de l'Université de São Paulo. São Paulo. 2021.

Dans cette thèse, nous avons comme objectif premier de démontrer que les droits de propriété intellectuelle, et plus fortemente des marques et brevets constituons développement inégal des mécanismes qui se reflète dans l'espace, dans la mesure où créer des monopoles technologiques et des connaissances scientifiques en faveur des acteurs hégémoniques de l'économie mondiale. Ils sont des instruments de manutention et aprofundissement de la division international de travail. Comme deuxième objectif, nous maintenons que le principal acteur hégémonique, c'est-à-dire les États-Unis, que a initializé son procéss de dévélopment a partir du dernière quartier du sécle XIX, suivi plus tard par Japan et des pays éuropéene occidental avec ses entreprises, est em train d'être dépassé par la Chine, cent ans aprés. Dans un contexte de transition, nous faisons brève incursion pour faire valoir que la montée et une éventuelle hégémonie chinoise, mais avec autre face culturelle, font une géopolitique et géoéconomique peu différente, puisque la Chine fait la même jeu de puissance dedans un même sistème global d'unité tecnologique. Utilisé comme la méthode de travail de recherche analytique de l'enregistrement des marques et des brevets dans les institutions internationales, les transactions et les litiges portant sur les brevets et les marques ainsi que les documents de lecture larges qui prennent soin que la montée de la Chine et de l'Est en général, mais plus fortement de la littérature des dernières décennies, quand cette hausse devient plus visible et les classiques de la Geographie et de 1’Economie. Les résultats présentés confirme les hypothèses initiales de l'étude, avec une conclusion que la Chine a déjà un pouvoir important au point de dire que déjà partage de l'hégémonie américaine.

Mots-clés: Marques. Brevets d’inventions. Développement inégal. États-Unis. Chine. 


\section{LISTA DE MAPAS}

Mapa 1 - Localização das montadoras automotivas na China .......................................... 115

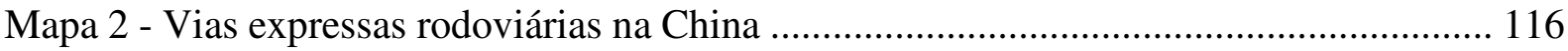




\section{LISTA DE FIGURAS}

Figura 1 - Desempenho industrial dos Estados Unidos, China, Suíça e Brasil

Figura 2 - Desempenho industrial do Reino Unido e Coréia do Sul 57

Figura 3 - Receitas oriundas da cobrança de propriedades intelectuais 106

Figura 4 - Crescimento das propriedades intelectuais - Estados Unidos, China, Japão e Brasil -2002-2016 em gráfico comparativo 110

Figura 5 - Crescimento das propriedades intelectuais - Estados Unidos, China, Japão e Brasil -2002-2016 em tabela 111

Figura 6 - Estradas de ferro na China em 2018 117

Figura 7 - Quadro de disputas comerciais envolvendo a China 118 


\section{LISTA DE TABELAS}

Tabela 1 - Totalidade de marcas registradas nos EUA, China, Japão e Brasil 28

Tabela 2 - Pedidos de registros de marcas por chineses ou empresas chinesas no exterior e de americanos ou empresas americanas no exterior

Tabela 3 - Quadro comparativo de PIB, Poder Militar e Índice de Patentes

Tabela 4 - Pedidos de patentes no Brasil, EUA, China, Suíça e Argentina .78

Tabela 5 - Pedidos de registros de marcas no Brasil, EUA, China, Suíça e Argentina 79

Tabela 6 - Relação percentual de patentes e marcas empresariais em 2019 81

Tabela 7 - Participação de mercado das empresas de telefonia celular 94

Tabela 8 - Patenteamento na China por setores em porcentagem - 2016

Tabela 9 - Participação de EUA e China nas exportações mundiais - em porcentagens

Tabela 10 - Quadro comparativo da economia Estados Unidos - China 2016/2019

Tabela 11 - Níveis de industrialização per capita -1880-1938

Tabela 12 - Potencial industrial total das potências em perspectiva relativa 120

Tabela 13 - Patentes em vigor na China e nos Estados Unidos 124

Tabela 14 - Pedidos de patentes nos Estados Unidos e China 125

Tabela 15 - Pedidos de patentes nos Estados Unidos e China junto ao PCT 125

Tabela 16 - Pedidos de patentes no PCT na China nos anos de 2018 e 2019 134

Tabela 17 - Pedidos de patentes no PCT na China no ano de 2012 134 


\section{LISTA DE FOTOGRAFIAS}

Fotografia 1 - Centro de Práticas Esportiva da USP. Publicidade do Banco Santander

Fotografia 2 - Água Mineral Aquafina da Pepsi .............................................................. 45

Fotografia 3 - Água Mineral Pure Life da Nestlé ............................................................... 45

Fotografia 4 e 5 - Água Mineral Dasani da Coca-Cola em Missouri - EUA ...................... 45

Fotografia 6 e 7 - Água Mineral Aquarius da Coca-Cola .................................................. 47

Fotografia 8 e 9 - Água Mineral Hua Run Chinesa ......................................................... 47

Fotografia 10 e 11 - Água Mineral em Seul - Coréia do Sul .............................................. 49

Fotografia 12 - Água Mineral Crystal da Nestlé em São Paulo - Brasil .............................. 49

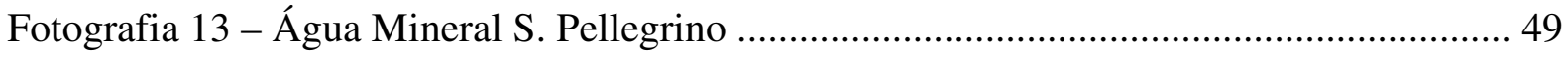

Fotografia 14 - Água Mineral Dasani da Coca-Cola em Assunção - Paraguai ..................... 50

Fotografia 15 - Água Mineral Naturaleza da Ciego/Coca Cola em Havana - Cuba .............. 50

Fotografia 16 - Água Mineral Dasani da Coca-Cola e Evian da Danone em Toronto - Canadá

Fotografia 17 - Água Mineral Highland - Escócia .......................................................... 51

Fotografia 18 - Água Mineral Thonon - França ............................................................. 51

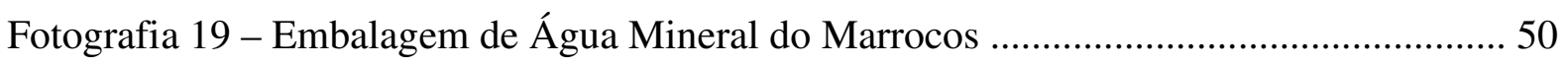




\section{LISTA DE IMAGENS}

Imagem 1 - Marcas de água Nestlé 43

Imagem 2 - Marcas de água Danone 43

Imagem 3 - Marca de água Baikalika - Site Alibaba 48 


\section{LISTA DE ABREVIATURAS E SIGLAS}

EPA - Environmental Protection Agency - Agência de Proteção Ambiental (dos Estados Unidos)

GATS - General Agrement on Trade and Services. Acordo Geral de Tarifa e Comércio.

IPEA - Instituto de Pesquisa Econômica Aplicada

INPI - Instituto Nacional da Propriedade Intelectual

OMC - Organização Mundial do Comércio

OMPI - Organização Mundial da Propriedade Intelectual

ONU - Organização das Nações Unidas

PCT - Patent Cooperation Treaty - Tratado de Cooperação de Patentes

PIB - Produto Interno Bruto

TRIPS - Trade Related Intellectual Property Rights Agreement - Acordo sobre Direitos de Propriedade Intelectual relacionados ao Comércio

UNCTAD - United Nations Conference for Trade and Development - Conferência das Nações Unidas para o Comércio e Desenvolvimento

USPTO - United States Patent and Trademark Office - Escritório de Patentes e Marcas Registradas dos Estados Unidos 


\section{SUMÁRIO}

INTRODUÇÃO

Princípios norteadores de metodologia, teoria e método …........................................... 03

\section{PRIMEIRA PARTE}

AS MARCAS EMPRESARIAIS

Capítulo 1

A marca como instrumento semiótico

Capítulo 2

A marca como instrumento jurídico

Capítulo 3

A marca como instrumento econômico

Capítulo 4

As marcas na reprodução do espaço

Capítulo 5

A geopolítica da marca empresarial 36

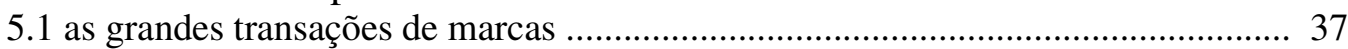

5.2 a geopolítica das marcas de águas minerais ........................................................... 40

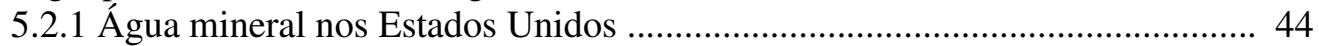

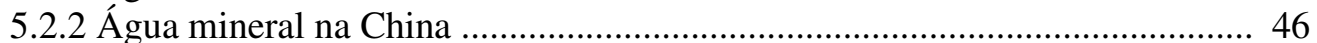

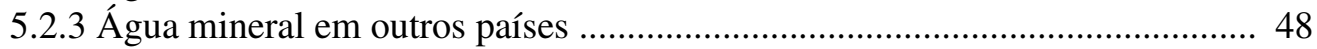

\section{SEGUNDA PARTE}

AS PATENTES DE INVENÇÃO

\section{Capítulo 6}

As patentes como instrumentos de desenvolvimento tecnológico, econômico e militar

Capítulo 7

Geopolítica das patentes e concorrência no centro do sistema capitalista

Capítulo 8

A relação entre as marcas empresariais com a patente e a inovação 
Capítulo 9

Os Investimentos Estrangeiros Diretos 83

Capítulo 10

A geopolítica das patentes dos telefones celulares 90

\section{TERCEIRA PARTE}

A COMPETIÇÃO ENTRE ESTADOS UNIDOS E CHINA PELA LIDERANÇA DAS MARCAS E PATENTES

Capítulo 11

A Ascensão da China 107

Capítulo 12

A competição entre Estados Unidos e China 119

Capítulo 13

O papel do Estado e a relação com as empresas

Capítulo 14

Um Mundo Bipolar 136

Capítulo 15

O Estado da Arte e da Técnica na corrida rumo à hegemonia 143

CONSIDERAÇÕES FINAIS 152

REFERÊNCIAS 155

ANEXOS 168 


\section{INTRODUÇÃO}

Os direitos de marcas registradas e patentes de invenção são conhecidos como direitos industriais, ao lado de desenhos industriais, modelos de utilidades, indicações geográficas, cultivares de plantas e topografias de circuitos integrados, todos eles classificados dentro de uma categoria mais geral denominados de direitos de propriedade intelectual, em que se integram também os direitos autorais, que não são considerados industriais como aqueles primeiros mas visam, como todos eles, a proteção dos conhecimentos e artes expressos pelo gênio da criação humana. A marca empresarial como um sinal ou termo distintivo para a mercadoria que facilita a escolha do consumidor e a patente de invenção como resultado de uma criação engenhosa que vem melhorar, tecnicamente, a vida das pessoas tornando-a mais fácil, são dois dos mais importantes desses direitos que repercutem com grande intensidade na configuração e reprodução do espaço.

Observamos que esses direitos intelectuais, historicamente, se aprofundam e se tornam mais rígidos em momentos de crise da economia mundial, quando a necessidade de auferir rendas faz com que as empresas que obtiveram inovação de produtos e serviços protejam mais suas criações ou passem a cobrar com mais rigor a exploração por terceiros através de licenciamentos dessas inovações alcançadas. Nesse sentido é possível distinguir fases de enrijecimento da legislação mundial sobre o tema quando fazemos a análise comparativa e cronológica dos tratados e convenções internacionais levando em conta a cronologia de crises econômicas, em especial quando adotamos como critério os ciclos econômicos de Kondratieff, segundo o qual há ciclos de 50 anos compreendendo um período de 25 anos de expansão da economia, frutos da inovação tecnológica, seguida de 25 anos de retração, quando as inovações são absorvidas por todo o mercado e fazem abaixar os preços gerais das mercadorias. Observamos, porém, que o recrudescimento desses direitos tem se dado de maneira contínua e constante desde os anos de 1970, se amplificaram através de um Acordo Internacional em 1994 e continua, com a criação de novas modalidades de proteção, em especial no campo das marcas empresariais.

$\mathrm{Na}$ fase atual do capitalismo, como ficará demonstrado com a presente tese, é imperativo reconhecer que esses direitos de propriedade intelectual, aqui focados nos direitos de marcas e patentes, visam a proteção do conhecimento tecnológico (patentes) 
e do poder econômico (marcas) das empresas hegemônicas, criando monopólios dos países do centro do sistema econômico (Estados Unidos, Japão e Europa), o que leva à manutenção e aprofundamento de um espaço regional e mundial crescentemente desigual, aprofundando a divisão internacional do trabalho. Procuramos mostrar com o presente trabalho que a China, com um notável crescimento quantitativo das marcas e patentes, atingiu um desenvolvimento qualitativo da economia em geral com uma grande diversidade na economia e notável inovação na indústria. E acabamos por afirmar, com a tese, de que a China é hoje uma potência econômica mundial, ao lado dos Estados Unidos, ou mesmo a sua frente, em decorrência de sua potência nos direitos de propriedade intelectual. Enfim, procuraremos demonstrar que a aquisição de propriedades intelectuais não é mero resultado da riqueza, mas se trata também de instrumento para atingi-la plenamente.

Para a demonstração de nossos pressupostos constituintes da tese apresentamos a pesquisa em três partes. A primeira destina-se a apresentar os direitos da marca empresarial em seus aspectos semióticos, jurídicos, econômicos e geopolíticos fazendo, na mesma parte, em seguida uma reflexão de sua nefasta consequência na reprodução do espaço, na medida em que é um instrumento importante e símbolo maior das grandes empresas transnacionais na apropriação do espaço público e indutor no aprofundamento das desigualdades e segregações espaciais.

Na segunda parte, fazemos uma incursão pelos direitos de patentes, como a outra face dos direitos intelectuais industriais que sustenta e dá suporte técnico à exploração dos direitos de marca. Para tanto exploraremos a literatura da economia e da administração que demonstram a importância da inovação para as empresas transnacionais dos países centrais na manutenção de sua hegemonia tecnológica e cultural.

Por fim, na terceira parte fazemos a demonstração de como os Estados Unidos da América ainda é ao final da segunda década do século XXI um poder econômico, mas que divide, paulatinamente, ano a ano, esse poder com a China, que assume a dianteira, de maneira consistente, em diversas áreas da tecnologia, fazendo-nos questionar sobre o significado desta ascensão.

Em todas as três partes utilizamos de dados oficiais obtidos de órgãos internacionais para a demonstração dos pressupostos, em pesquisa fortemente baseada na empiria dos direitos intelectuais industriais, especificamente os direitos de marcas e patentes. 
PRINCÍPIOS NORTEADORES DE METODOLOGIA, TEORIA E MÉTODO

Para o nosso postulado de que as marcas e patentes se constituem no instrumento principal, atualmente, da reprodução do espaço desigual que se estende das configurações do espaço global à cidade, pelos atores hegemônicos, utilizamos de análises quantitativas consistentes nos registros encontrados principalmente na Organização Mundial da Propriedade Intelectual, na Organização Mundial do Comércio e no Banco Mundial e algumas informações dos escritórios de marcas e patentes dos países analisados. Contudo, os números servem antes para confirmar a tese, fundamentada, sobretudo, em análises qualitativas dos direitos, e dos estudos já elaboradas em geografia sobre a dominação das grandes empresas sobre os territórios, em especial dos espaços urbanos.

A atualidade das obras de Karl Marx e os teóricos que o adotam como instrumento de análise para uma fundamentação teórica é ainda notória, posto que elaboramos a pesquisa tendo o seu objeto (Direito de Marcas e Patentes), como um de seus principais mecanismo de conquista (ou mais precisamente de reserva e monopólio) de mercado, situado no contexto do desenvolvimento do capitalismo, que continua sendo o modo de produção dominante no mundo. Os direitos intelectuais garantem aos donos dos meios de produção o monopólio das duas vertentes fundamentais: o monopólio do conhecimento no aprimoramento técnico (inclusive das máquinas) pelo direito de patente e o monopólio da comercialização das mercadorias através do eficiente direcionamento do consumo, pelo direito de marca. Para a abordagem da marca que reveste a mercadoria (o objeto técnico), e a patente que a protege, nada mais atual que o conceito de alienação, agora não apenas tanto pela incapacidade monetária do trabalhador de a adquirir, mas mais pela incapacidade de apreensão do produto, diante da fragmentação na produção das mercadorias que se dá atualmente por partes, em que cada parte é produzida em um lugar diferente do mundo, atendendo a um pressuposto de menor custo (nas ciências econômicas se usa do conceito de global value $\operatorname{chain}^{l}$ ). Há de se ressaltar ainda que essa

\footnotetext{
${ }^{1}$ Em nossa tradução livre do inglês "cadeia de valor global”. O Banco Mundial o conceitua como "a série de estágios na produção de um produto ou serviço para a venda aos consumidores. Cada estágio acrescenta um valor, e pelo menos dois estágios se encontram em países diferentes. Disponível em: file:///C:/Users/eanda/Downloads/9781464814570.pdf. Acesso em 14/10/2020.
} 
fragmentação se dá também com o objetivo de dificultar o conhecimento do processo total de produção pelos atores de produção em cada localidade.

Ao tratarmos da importância das marcas na valorização dos produtos, fazemos uso da obra de Adam Smith, clássico que ajuda a compreender a dinâmica capitalista de seus primórdios. Autores da economia política, portanto, não podiam ficar de fora na fundamentação de uma questão que é eminentemente econômica. Quando estamos a falar dos direitos de marcas e patentes estamos a falar de monopólio econômico, que contrasta, juridicamente, ao princípio da livre concorrência do mercado.

Milton Santos, ao elaborar seu conceito de elementos do espaço, como constituintes da totalidade, elenca os elementos "os homens" e as firmas ${ }^{2}$. As marcas empresariais são a expressão mais visível das firmas. E os homens podem ser tomados como firmas, na medida em que a intercambialidade e a redutibilidade aumenta com o desenvolvimento histórico, como resultado da "complexidade crescente" (SANTOS, 2012, p. 16-17). Autor este, assim, importante para a sustentação de muitos de nossos pressupostos.

A esse propósito sobre os homens sob o capitalismo que surge após a $2^{\mathrm{a}}$ Guerra Mundial, Michel Foucault, retomando o conceito de homo oeconomicus elaborou a ideia do homem como empresário de si mesmo, segundo a lógica neoliberal que toma forma a partir dos anos 1970 (FOUCAULT, 2008). A obra de Foucault centrando a análise na disciplina imposta ao homem dentro do conceito que chamou de biopolítica é fundamental para o entendimento do consumismo que tomou conta do mundo a partir desses anos, impulsionado pelo acesso da classe trabalhadora aos bens de consumo no período de pós-guerra que economistas chamam dos “Trinta Gloriosos”. Tal consumismo se faz mediante a exploração de marcas, construídas essencialmente nos países centrais da economia e exportadas à periferia do sistema como um bem em si, embora se revista de imaterialidade em sua formulação jurídica. Seguindo ainda a linha foucaultiana, avançamos para Byung Chul Han (2017) para quem toda essa proliferação de informações do mundo atual e a demanda por desempenho individual nos levou a uma sociedade cansada em que o sistema faz com que cada um se explora a si mesmo na busca de um suposto sucesso pessoal.

A abordagem que fazemos do Direito, por outro lado, leva em conta o novo entendimento em Direito Internacional de que uma nova noção de espaço deve ser

\footnotetext{
${ }^{2}$ Os outros elementos são "as instituições, o chamado meio ecológico e as infra-estruturas".
} 
considerada. Sem que se reconheça o fim do Estado nacional, e de seu território, é imperativo aceitar que os regimes surgidos dos tratados internacionais traz uma inevitabilidade de submissão dos países, dado o contexto de envolvimento (preferível à “integração") global e nesse quadro o direito internacional tem passado por "uma série de questionamentos sobre a sua especificidade como disciplina no campo do direito", diante dos vetores dessa globalização que mencionamos, que "acentuados a partir da década de 1980, que conhecidamente ampliaram as associações regulatórias, diminuíram os espaços e relativizaram as barreiras espaciais (BADIN, DE BRITO E VENTURA, 2016, p. 9).

Fazemos neste trabalho, portanto, uma análise que colhe dados da economia, como os índices mundiais das marcas e das patentes das duas principais potências econômicas, e secundariamente de outros países para análises comparativas e parte para uma consideração dos direitos de marcas e patentes indissoluvelmente imbrincados no domínio e apropriação dos espaços geográficos do cotidiano ou, nas palavras de Milton, no território usado. Uma análise assim que vai da escala mundial para o espaço vivido e usado pelo indivíduo, subjugado à lógica neoliberal do corpo disciplinado.

Sobre as questões metodológicas para entendimento da metrópole, Antonio Carlos Robert Moraes (2006, p. 25) afirma que se impõe a distinção entre o centro e a periferia da economia-mundo capitalista e as determinações e mediações nacionais e regionais na explicação dos espaços metropolitanos, o que torna indispensável uma análise multiescalar. Para o processo de metropolização, ainda segundo Moraes (2006, p. 26), como processo universal, caberia uma teoria geral que o qualificaria como forma geográfica histórica. Por fim, "Assim, tanto a geografia econômica quanto a geografia política contribuem como vetores de explicação das realidades e do movimento das metrópoles, fornecendo focos interessantes para diferentes abordagens de tais espaços contemporâneos" (MORAES, 2006, p. 24).

Portanto, a tese faz uma análise quantitativa na demonstração dos grandes números que se revelam pelos registros de marcas e patentes, pelas transações e litígios mundiais entre as grandes empresas transnacionais, ao mesmo tempo que analisa, de modo qualitativo e dialético, em diferentes momentos o espaço e o território, onde a força dessas empresas se faz presente. Transita assim, este trabalho, pelas esferas das ciências econômicas, política, e jurídica, centrando-se, porém, na geografia econômica, política e a geografia urbana. Filiamo-nos entre aqueles que entendem ser a Geografia única, como Carlos Augusto de Figueiredo Monteiro e fazemos assim uso de suas diversas abordagens como método de melhor compreender a totalidade do mundo presente. 
Nosso método pode ser assim anunciado: As marcas empresariais que dominam o espaço geográfico devem ser compreendidas em suas diversas facetas (simbólica, jurídica e econômica) em um primeiro plano, para se passar ao necessário reconhecimento de que essas marcas se sustentam em virtude de investimentos e são as expressões visíveis de uma batalha pela hegemonia econômica, política e militar. Passamos, então, ao terceiro capítulo, onde se analisa a disputa pela liderança dessa hegemonia, que traz repercussões globais e territoriais. Marcas, Patentes e Poder Político e Econômico, eis o edifício de nossa tese.

Tratamos de definir e situar, portanto, os direitos das marcas e patentes e a partir do universo jurídico (como pertencente, portanto, em princípio, à esfera de superestrutura, mas em dialético diálogo com o mundo real) como esses direitos se modulam e influenciam na configuração dos territórios, através da política das grandes corporações, se fazendo ideologia nas mentes e corações das pessoas em um mundo dominado pelo consumo. A partir dos dados quantitativos submetemos a análises históricas e comparativas a fim de demonstrar a correção de nossos pressupostos. Procuramos fazer com o cuidado que estabelece Sérgio Paulo Roaunet quando disserta sobre ética e antropologia:

"Como toda ciência, a antropologia está sujeita à jurisdição do discurso teórico. Ela recolhe o seu material na observação empírica, mas a validade dos enunciados relativos a tais observações precisa ser posta à prova numa comunidade argumentativa de pares, e só depois de atingido o consenso esses enunciados podem ser considerados válidos" (ROAUNET, 1990, p. 116).

Entendemos cabível substituir a Antropologia de Roaunet (1990) pela Geografia no enunciado transcrito, na medida em que colhemos material na observação empírica e o submetemos à prova da comunidade geográfica.

Ciente de que as marcas e patentes são direitos que explicam uma parte da desigualdade espacial, sem que desconsideremos os fatores históricos e políticos de outras naturezas, e que os fenômenos se explicam melhor pelas "múltiplas determinações" de Marx, defendemos que o estudo desta parte da realidade contribui para o entendimento do todo, porque a propriedade intelectual se torna a cada dia mais onipresente. Milton Santos (2012, p. 95) ao dissertar sobre o estudo das regiões produtivas afirma que o estudo do fenômeno que se quer compreender almeja a realidade social global obtendo dois resultados paralelos: "1 - Um melhor conhecimento da parcialidade que é o fenômeno 
estudado, através do reconhecimento de sua inserção no todo. 2 - Um melhor conhecimento do todo, graças à melhor compreensão do que é uma de suas partes".

Pretendemos, com o presente estudo, demonstrar a importância dos direitos das marcas e das patentes na gênese da indústria e como se inserem de forma fundamental nas esferas da produção, da circulação e do consumo, constituindo-se em parte capital do movimento que molda o espaço geográfico. Apesar de David Harvey (2012) ter abordado o tema de propriedade intelectual como instrumento de despossessão e concentração da renda e Milton Santos ter abordado a marca como instrumento da publicidade que induz ao consumismo de nosso tempo, e da técnica, mas sem se voltar especificamente às patentes, cremos que o presente tema não tem sido debatido com a presente especificidade e aprofundamento de forma crítica pela Geografia, existindo estudos apenas sobre direitos de propriedade industrial como mecanismos de desenvolvimento econômico, sem a criticidade de se atentar às desigualdades que promove ou o modo como se operam.

A diversidade de autores e seu ecletismo, acreditamos, não se constitui em embaraço ao método, porque o enunciado primário é claro: Os direitos decorrentes do registro de marcas empresariais e patentes de invenções é um mecanismo de monopólio, e, convergindo a literatura clássica e atual, podemos afirmar que se tratam dos principais instrumentos jurídico-políticos da conformação desigual do espaço mundial. A leitura e uso de biografias, de matérias jornalística, e mesmo de romances, se justificam porque a ascensão tecnológica para a qual voltamos o nosso olhar está em pleno acontecimento. Avançamos para demonstrar que esse monopólio amplia o poder das grandes empresas do centro dinâmico do capitalismo, aprofundando a crescente desigualdade. E o enunciado conclusivo também é claro: pela averiguação dos dados quantitativos observáveis e dados qualitativos, a China tem uma ascensão assombrosa neste tema, a igualar com os Estados Unidos, retirando desta o caráter de potência hegemônica única. 
"A riqueza das sociedades onde reina o modo de produção capitalista aparece como uma 'enorme coleção de mercadorias', e a mercadoria individual como sua forma elementar. Nossa investigação começa, por isso, com a análise da mercadoria" (p. 113).

4. O caráter fetichista da mercadoria e seu segredo.

Uma mercadoria aparenta ser, à primeira vista, uma coisa óbvia, trivial. Sua análise resulta em que ela é uma coisa muito intrincada, plena de sutilezas metafísicas e melindres teológicos. Quando é valor de uso, nela não há nada de misterioso, quer eu a considere do ponto de vista de que satisfaz necessidades humanas por meio de suas propriedades, quer do ponto de vista de que ela só recebe essas propriedades como produto do trabalho humano. É evidente que o homem, por meio de sua atividade, altera as formas das matérias naturais de um modo que lhe é útil. Por exemplo, a forma de madeira é alterada quando dela se faz uma mesa. No entanto, a mesa continua sendo madeira, uma coisa sensível e banal. Mas tão logo aparece como mercadoria, ela se transforma numa coisa sensível-suprassensível" (p. 146).

(Marx, Karl. O Capital. Livro 1. 2013) 


\section{PRIMEIRA PARTE}

\section{AS MARCAS EMPRESARIAIS}

As marcas empresariais hoje estão presentes em todos os espaços públicos e privados, urbanos ou rurais, abarcando quase todos os territórios mundiais. As marcas das grandes empresas transnacionais, estampando corredores dos metrôs, as latarias dos ônibus e dos sistemas de transportes e circulação, patrocinando e dando nome a estádios de futebol, centros comerciais e demais fixos geográficos, nas camisetas e sacolas das pessoas, influenciando em suas ações de consumo e de comportamento, levam à falsa impressão de uma certa uniformidade ou homogeneização dos espaços mundiais. A impressão é falsa porque, apesar de similaridades de paisagens, a cobrança dos chamados "royalties" ou licenças para uso dessas marcas pelas empresas franqueadas leva à concentração da renda nas mãos dessas empresas transnacionais, em suas sedes, em geral nos países do centro rico do capitalismo, que se tornam cada vez mais hegemônicas. E é ainda falsa porque as marcas criam espaços separados e divididos, criando categorias diferenciadas de consumidores, em que o consumo substitui a cidadania.

Na cidade de São Paulo, para tomarmos um exemplo mais próximo, como nas grandes cidades em todo o mundo, são notórias as circunscrições comerciais distintas para o público de poder aquisitivo mais alto e os comércios populares, onde a proliferação das grandes marcas empresariais também acontece, mas na forma contrafeita. É a tal da pirataria, a reprodução ou imitação ilícita de produtos carregando marcas famosas. Tal a importância que a marca ganhou em todas as esferas de consumo.

As marcas adentraram, assim, em espaços públicos, que deveriam estar resguardadas do poder e da ingerência da atuação privada, como universidades, ruas, parques e espaços de cultura e lazer. Cada vez mais essas instâncias públicas são geridas sob a lógica da gestão privada do poder hegemônico dessas empresas, sendo a marca empresarial o instrumento e o símbolo mais notórios dessa ingerência e dessa submissão do público pelo privado.

Diversas dimensões espaciais e comportamentais repercutem e são repercutidas a partir da adoção da marca empresarial nas esferas da existência humana, o que demanda uma análise da sua força e do seu poder, procurando entender o seu simbolismo. As razões que se encontram subjacentes nas transações das marcas que alcançam os bilhões de dólares americanos. As questões geopolíticas por trás do avanço 
das marcas pelos países e o papel dos estados nacionais na defesa das marcas das empresas que tem origem e sede em suas circunscrições, são alguns dos temas que procuramos tratar.

Para Natália Figueiredo (2015. p. 15) a partir dos anos 1950 do século XX, os produtos sobretudo da indústria automobilística começaram a ter qualidades muito semelhantes e inicia um processo de relativa "estandartização", a partir do qual empresas como Procter and Gamble, General Foods e Unilever passaram a desenvolver o marketing e "Isto exigiu maior conhecimento e entendimento do consumidor específico e da marca que deveria oferecer não só um valor funcional, mas também emocional”, passando a ser uma "estratégia corporativa de diferenciação e fidelização do consumidor", estratégia esta acentuada a partir dos anos 1980 (Figueiredo 2015, p. 15).

A marca passa, portanto, a ser um ativo imaterial das grandes empresas, e acaba exercendo funções econômicas diversas, como, por exemplo, segundo ainda Figueiredo (2014) em barreira a entrada de novos produtos concorrentes quando uma empresa atinge uma notável diferenciação combinada com pesados investimentos em publicidade, constituindo-se em verdadeiros monopólios.

A marca empresarial ganha então uma centralidade, deixando de ser uma questão da esfera do consumo para voltar-se também à esfera da produção, como veremos nas análises que se seguem. 


\section{Capítulo 1}

\section{A marca como instrumento semiótico}

O economista do desenvolvimento Ha Joon Chang $^{3}$ para ressaltar a importância da produção industrial ainda nos dias de hoje afirma que nunca antes estivemos rodeados de tantos bens materiais. Esses bens materiais são objetos e, para a tese que aqui se busca afirmar, são objetos em sua grande maioria dotados de uma marca empresarial e de uma tecnologia que fora protegida quando de sua criação, constituindose essa proteção naquilo que em direito se chama de patente de invenção, modelo de utilidade ou desenho industrial, as três espécies de proteção industrial. Não são assim meramente coisas, como eram antes na fase que Milton Santos (1996) denomina de período natural. Os objetos são assim produtos da engenhosidade humana e que nos rodeiam e carregam assim uma marca e funcionam segundo um conhecimento protegido pela patente.

A marca desses objetos que nos rodeiam e que aqui é foco do estudo é uma marca empresarial. Mas é, sobretudo, um signo, um sinal, carregando um conceito e um sentido. Procuramos nesta tese ir além dos sinais exteriores que são associadas a esses objetos, e buscar compreender suas representações e significados que carregam. A rigor, todos os objetos são carregados de sinais. Para Edmund Husserl (1890):

"Qualquer qualidade, [341] seja ela absoluta ou negativa, pode servir ocasionalmente como sinal marcante do objecto que a possui. É evidente que aqui reside a fonte dos equívocos do nome 'marca': no seu sentido originário significa o mesmo que sinal, sendo depois restringido às qualidades tomadas como sinais, para no fim, em sentido figurado (in übertragenem Sinn), significar o mesmo que qualidade em geral. No entanto, não é em todas as circunstâncias que uma qualidade nos serve de sinal, embora cada uma possa servir ocasionalmente para esse fim. Por vezes, interessam-nos as qualidades do alumínio enquanto tais, na medida em que enriquecem o conhecimento que temos desse metal; noutros casos, porém, podem precisamente as mesmas qualidades, constatadas num corpo ainda desconhecido, serem utilizadas como sinais marcantes de que se trata justamente de alumínio" (HUSSERL, 1890, p. 1).

\footnotetext{
${ }^{3}$ Informação fornecida em palestra na Pontifícia Universidade Católica de São Paulo, em janeiro de 2018. Evento com informação disponível em : http://www.pucsp.br/evento/seminario-reconstruindo-o-discursosobre-desenvolvimento-economico-producao-e-financiamento. Acesso em 29/01/18.
} 
É importante destacar que o signo é uma representação de um objeto. Não é o objeto em si. Esses signos e as marcas que são carregados por esses objetos em um mundo fortemente caracterizado pelo consumo se constituem em um tema que vem ajudar na compreensão da paisagem geográfica em permanente mudança. Jean Baudrillard já nos anos 1970 focou parte de seu estudo na compreensão dessa realidade. Afirma Baudrillard (2008, p. 9) que "A civilização urbana vê sucederem-se, em ritmo acelerado, gerações de produtos, de aparelhos, de gadgets, frente aos quais o homem parece uma espécie particularmente estável”. Entendemos que no mundo contemporâneo não há diferença acentuada entre o urbano e o rural e a tecnologia empregada no campo é um claro sinal desta assertiva. O campo está subordinado ao modo de produção, é parte integrante do espaço social e contém os mesmos objetos da civilização urbana, com suas máquinas de marcas notórias, submetida à lógica também da exploração de propriedades intelectuais, como a biotecnologia, o cultivares de plantas, e as denominações de indicações geográficas, direitos esses cujo uso deve se dar mediante o pagamento de licenças a grandes empresas detentoras dessas propriedades intelectuais.

Para Milton Santos “A cada evolução técnica corresponde uma nova forma de organizar o espaço. Não se pode obter a compreensão do espaço prescindindo-se da posse da significação exata dos instrumentos de trabalho: casas, estradas, fábricas, barragens, etc" (SANTOS, 2002, p. 137). Ainda para Santos (2002, p. 137) "A transformação da tecnologia em técnica é subordinada a dados econômicos, políticos, ideológicos; daí a necessidade da intervenção dos ensinamentos das ciências respectivas", dentre as quais destaca a semiologia como contribuição "para separar o significado assim outorgado ao objeto do seu valor real" (SANTOS, 2002, p. 138).

A força das marcas empresariais é de tal monta que não raras vezes a própria empresa se confunde com uma de suas marcas e passam a ser conhecidas como tais, algumas vezes com repercussão no modo de denominar lugares. A marca "xerox" se tornou sinônimo de fotocopiadora. A marca "bombril" se tornou sinônimo de esponja de aço. Inicialmente, no Brasil, a marca "Danone" havia se tornado sinônimo de iogurte. Em um espectro mais amplo espacialmente, a marca engloba bairros inteiros. Na cidade de São Roque, no Estado de São Paulo, por exemplo, há um bairro e uma estação de trem (atualmente desativada) que se denominam Fazenda Cinzano e Parada Cinzano. Tal denominação decorre da existência ali da fábrica de bebidas do Grupo Campari.

Yi-Fu Tuan (2012, p. 21-22), em seu famoso estudo sobre a percepção, atitudes e valores das pessoas, após ressaltar que "Duas pessoas não veem a mesma 
realidade", afirma que "Todos os seres humanos compartilham percepções comuns, um mundo comum, em virtude de possuírem órgãos similares" e que "Dos cinco sentidos tradicionais, o homem depende mais conscientemente da visão do que dos demais sentidos para progredir no mundo. Ele é predominantemente um animal visual". E quando falamos em marcas empresariais estamos falando eminentemente em marcas figurativas ou nominativas perceptíveis pela pessoa através da visão ${ }^{4}$.

A falar das estruturas e respostas psicológicas comuns dos seres humanos diante do meio ambiente, Tuan (2012, p. 31) remete sua pesquisa ao cérebro humano, afirmando que "os seres humanos ostentam uma capacidade altamente desenvolvida para o comportamento simbólico. Uma linguagem abstrata de sinais e símbolos é privativa da espécie humana”. Avançando no tema, Tuan (2012, p. 45) aborda a importância das cores e afirma que "A sensibilidade humana para as cores manifesta-se em idade muito precoce. Até bebês de três meses parecem capazes de fazer discriminações. As cores, que desempenham um papel importante nas emoções humanas, podem constituir os primeiros símbolos do homem".

Carl G. Jung faz uma distinção entre sinais e símbolos. O autor disserta sobre o símbolo como termo ou imagem que possui conotações especiais além do significado evidente e convencional e que "implica alguma coisa vaga, desconhecida ou oculta para nós” (Jung, 2002, p. 20). Para o autor as abreviações (ONU, UNICEF, UNESCO) os nomes de remédios patenteados, divisas, insígnias e as marcas comerciais conhecidas não são símbolos, "são sinais e servem, apenas, para indicar os objetos a que estão ligados" (2002, p. 20). Este texto do autor é de 1964, quando as marcas comerciais já possuíam uma importância grande na economia, mas não na extensão que ganhou nos anos 1980 conforme relato de Naomi Klein (2002) quando então passam a ser a preocupação central das grandes corporações, que terceirizam a produção dos seus produtos para países do terceiro mundo e centram o foco no processo de construção de marcas. No atual estágio da economia e do consumo mundial, as marcas das empresas apresentam um caráter simbólico que afeta a psicologia das pessoas, que vai além da mera indicação dos objetos.

A questão do simbolismo e das cores, por exemplo, é relevante para a tese que procuramos construir porque explica a razão do direito de marcas ter avançado a tal

\footnotetext{
${ }^{4}$ A empresa de entretenimento MGM, antiga Metro-Goldwyn-Mayer, tenta fazer do rugido do leão que abre suas produções cinematográficas, uma marca sonora. Reconhecida nos Estados Unidos ainda não foi aceita na União Européia. Da mesma forma a Globo não obteve sucesso na tentativa de registrar como marca o som do "plim-plim", característico das chamadas de intervalo de sua programação.
} 
ponto na proteção de marcas das grandes empresas que reconhece hoje que uma combinação simples de cores pode se constituir em uma marca registrável. O verde e o amarelo sobre as letras "BR" se constituem, por exemplo, em uma marca protegida da empresa petrolífera Petrobrás, o que impede concorrentes de usarem das mesmas cores, na mesma disposição gráfica, em seus anúncios publicitários. Ou seja, o verde e o amarelo se constituíram em marca, em propriedade intelectual, privada, de uso exclusivo de uma empresa, quando na verdade, por serem as cores nacionais, deveriam ser de uso comum e público, em especial porque seguidas das letras "BR", abreviatura para o nome do país. Ou seja, um símbolo comum, público, que em tese, em Direito tradicional não poderia ser apropriado com exclusividade por agente da esfera privada.

Exemplo internacional de força de uma marca figurativa que identifica a empresa na memória das pessoas (e é isso também uma das funções da marca empresarial) é o tigre "Tony" do cereal matinal da americana Kellogg's, criada em 1952 pela agência Leo Burnett: "O Tony é a cara do Sucrilhos. Um não existe sem o outro. A ideia de energia, de uma pessoa forte, é o referencial da marca, e o Tony ajudou a construir essa imagem" (PIRICHINSKY, 2019, p. 20).

Esse espetáculo de símbolos e cores faz parte e fomentam o que Guy Debord denominou de "Sociedade do Espetáculo". Publicado pela primeira vez em novembro de 1967, Debord (2003, p. 13) afirma que "Toda a vida das sociedades nas quais reinam as condições modernas de produção se anuncia como uma imensa acumulação de espetáculos. Tudo o que era diretamente vivido se esvai na fumaça da representação". Assevera ainda que "O espetáculo é ao mesmo tempo parte da sociedade, a própria sociedade e seu instrumento de unificação", sendo que essa unificação "não é outra coisa senão a linguagem oficial da separação generalizada".

Sendo os fatos da vida nas sociedades capitalistas, verdadeiros ou falsos, um espetáculo, “O espetáculo não é um conjunto de imagens, mas uma relação social entre pessoas, mediatizadas por imagens" (DEBORD, 2003, p. 14). O que as marcas empresariais figurativas são senão mediação das relações de consumo? Para Debord (2003, p. 15) "Sob todas as suas formas particulares de informação ou propaganda, publicidade ou consumo direto do entretenimento, o espetáculo constitui o modelo presente na vida socialmente dominante" e "Onde o mundo real se converte em simples imagens, estas simples imagens tornam-se seres reais e motivações eficientes típicas de um comportamento hipnótico" (2003, p. 19). 
Hoje, mais que produzir produtos, as empresas têm a preocupação de produzir marcas, tendo em vista os enormes e crescentes orçamentos destinados à publicidade. Para Milton Santos (2002) o ato de produzir é também o ato de produzir espaço e que "a gênese deste se realiza sob o signo da ideologia, desde que a criação mercantil do espaço é em si mesma um jogo especulativo, um ato enganador. $\mathrm{O}$ marketing do espaço impõe o engano como se fosse a verdade". Afirmamos nesta tese que a marca empresarial é o principal instrumento da ideologia do consumo de nosso tempo.

Sem perder a perspectiva do indivíduo como consumidor que é submetido e submerge nesta ideologia do consumo de nosso tempo, entendemos que a análise deve ir além do estudo comportamental individual para abarcar a ideologia que se constitui como superestrutura, para usar um termo marxista, de nosso tempo. Milton Santos enfrentou esta questão em "Por uma Geografia Nova" (2002) nos seguintes termos:

"A geografia do comportamento vai ainda mais longe, porque se fundamenta no princípio mesmo da existência de uma escala espacial própria a cada indivíduo e também de um significado particular para cada homem, de porções do espaço que lhe é dado frequentar, não apenas em sua vida cotidiana mas ainda durante lapsos de tempo mais importantes" (SANTOS, 2002, p. 91).

Logo em seguida a essa passagem o autor afirma que essa tendência de abordar uma significação individual do espaço ainda não tenha sido "capaz de comprovar sua validez (SANTOS, 2002, p. 92). Seguimos a mesma linha para asseverar que o consumo das marcas, e mesmo em sua expressão contrafeita (nas formas do consumo de mercadorias piratas) se dá mediante um condicionamento geral, já que partimos do pressuposto que a liberdade humana (para o consumo?) não é absoluto e sim condicionada.

Na obra "O espaço dividido" (2002, p. 145), Milton Santos afirma que "A marca aparece como um elemento mágico, dando a impressão de continuidade de uma qualidade sem par (W. Lean, 1969, p. 7) 22. Seu efeito é limitar as possibilidades de escolha do varejista e eliminar os eventuais concorrentes (Baleste, 1972, p. 185)".

Henri Lefebvre denominou de "sociedade burocrática de consumo dirigida" para designar a sociedade que se firmava nos finais dos anos 1960, inundada que estava pela abundância do consumo permitida pela técnica e pelo tecnicismo do pós-guerra. Para Lefebvre (1969, p. 73) “a técnica e o tecnicismo surgem como álibis. A tecnocracia tem 
por álibi as aplicações da técnica à vida social; é ela própria um álibi - o dos verdadeiros dirigentes da economia e da política”.

E entendemos o fenômeno aqui estudado como um fenômeno mundial, ou mais propriamente global, daí a razão do foco voltado para as duas grandes potências das propriedades intelectuais. Milton Santos em trabalho que continua "Por uma Geografia Nova", que é "Metamorfoses do Espaço Habitado" (SANTOS, 1988), diz que:

"A universalização do mundo pode ser constatada nos fatos. Universalização da produção, incluindo a produção agrícola, dos processos produtivos e do marketing. Universalização das trocas, universalização do capital e de seu mercado, universalização da mercadoria, dos preços e do dinheiro como mercadoria-padrão, universalização das finanças e das dívidas, universalização do trabalho, isto é, do mercado de trabalho e do trabalho improdutivo, universalização do ambiente e das firmas e das economias, universalização dos gostos, do consumo, da alimentação" (1994, p. 14).

Como se procede à "universalização dos gostos, do consumo, da alimentação" senão através do marketing das marcas das grandes empresas transnacionais?

Ainda na mesma obra, assevera Milton Santos (1988, p. 71) que "O espaço é resultado da ação dos homens sobre o próprio espaço, intermediados pelos objetos naturais e artificiais". No mundo de hoje os objetos artificiais se revestem de uma marca, e como veremos, até mesmo a água, bem natural da humanidade, tem sido apropriada como mercadoria e vendida como marca. São objetos técnicos que compõem a tecnosfera, enquanto a marca, pela publicidade, é hoje indutor do consumismo exagerado. Portanto, ousamos dizer que a marca é o instrumento que conjuga a tecnosfera (porque traduz um objeto) com a psicoesfera (que motiva uma ação de consumo). Para Milton Santos (1999):

As relações técnicas e informacionais não podem ser 'indiferentes' ao meio social ambiente. As relações comunicacionais são, ao contrário, uma resultante desse meio social ambiente. As duas primeiras são mais dependentes da esfera da materialidade, da tecnosfera; as últimas o são mais da psicoesfera, mesmo se, em todos os casos, tecnosfera e psicosfera interagem" (SANTOS, 1999, p. 17).

No início dos anos 1990 em que um grupo de professores de Geografia fizeram um esforço de repensar o território a partir da globalização (SANTOS, DE SOUZA e SILVEIRA, 1996), Lucrécia D’Alessio Ferrara se propunha a pensar o mundo como imagem e a imagem do mundo afirmava que: 


\begin{abstract}
"A globalização do mundo é uma contradição: globaliza-se a partir de uma estratégia que emana de um centro de decisão econômico, o que supõe considerar, como consequência, uma periferia a esse centro; logo, não se globaliza o mundo, mas uma parte privilegiada dele; uma articulação renovada da conhecida estrutura centro/periferia que é manifestação lógica do poder" (FERRARA, 1996, p. 48).
\end{abstract}

Para a autora na globalização do imaginário se descreve o que ocorre em escala ascendente e se "constitui em um sistema de ordem que propõe a simetria da imagem pela qual todos os espaços, lugares, territórios, noções devem se dar a conhecer ou igualar-se" (FERRARA, 1996, p 49).

O que se impõe mais aos lugares e territórios em simetria igualitária a partir do centro do sistema econômico senão as marcas empresariais presentes em todos os espaços de vivência social? E como ressalta a autora, não se globaliza todo o mundo, mas apenas uma parte privilegiada dele. Qual é o percentual de pessoas no mundo, em especial os de fora dos países desenvolvidos que podem consumir os produtos de marca da alta moda europeia ou americana, os vinhos de indicações geográficas dos "terroir" franceses ou os aparelhos tecnológicos de alta potência das marcas americanas e japonesas? Mas essa pretensa homogeneização, "todos os espaços devem se dar a conhecer ou igualar-se" dia a autora (Ferrara, 1996, p. 49), é um imaginário apenas, um "espetáculo" nos dizer de Debord (1972) que não retrata a realidade dos fatos e aprofunda a desigualdade.

Surge assim, na tentativa de se parecer integrante da realidade do mundo, o mundo das marcas falsas, o mundo das cópias e imitações, em que os desprivilegiados se tornam consumidores de modo a não parecerem tão deslocados do mundo. Fabio Tozi (2012, p. 71) procurando compreender este mundo afirma que "os novos conjuntos técnicos agregados aos lugares permitiram novas maneiras de produzir e reproduzir", o que leva ao que falamos, na introdução deste trabalho, do enrijecimento da legislação de propriedade intelectual, e segundo Tozzi $(2012$, p. 71) a "novas formas de controle que de modo progressivo definem-se como leis inicialmente das metrópoles, posteriormente nacionais e finalmente internacionais”. Será preciso, portanto, para o centro do sistema econômico proteger as "criações originais" das piratarias do mundo das falsificações e imitações dos objetos técnicos surgidos e possibilitados pela "flexibilidade tropical" que nos fala Milton Santos. Como procuramos demonstrar ao longo desta tese, o estado da técnica é que permite o avanço tecnológico, sendo as principais inovações decorrentes de 
investimentos estatais, e daí porque então esses direitos se encontram fundamentados em pressupostos falsos 


\title{
Capítulo 2
}

\section{A Marca como instrumento jurídico}

Para o jurista Denis Borges Barbosa (2003, p. 801) a marca é a mais importante das propriedades intelectuais e é utilizada para designar um produto, mercadoria ou serviço. É objeto, ainda, da publicidade, podendo identificar a origem do produto, incitar o consumo e a valorização da atividade empresarial. Barbosa faz uma acurada conceituação da marca (2003):

\begin{abstract}
"Assim, marca é o sinal visualmente representado, que é configurado para o fim específico de distinguir a origem dos produtos e serviços. Símbolo voltado a um fim, sua existência fática depende da presença destes dois requisitos: capacidade de simbolizar, e capacidade de indicar uma origem específica, sem confundir o destinatário do processo de comunicação em que se insere: o consumidor. Sua proteção jurídica depende de um fator a mais: a apropriabilidade, ou seja, a possibilidade de se tornar um símbolo exclusivo, ou legalmente unívoco, em face do objeto simbolizado" (BARBOSA, 2003, p. 801/803).
\end{abstract}

Essa importância à marca dada pelo citado autor nos parece apropriada, na medida em que esse signo se faz presente em toda a vida das pessoas pelo mundo afora. Ela influencia o consumo, cria disputas judiciais entre empresas e está presente no espaço geográfico de maneira sobressalente na paisagem urbana, na publicidade dos meios de comunicação e nos objetos que nos rodeiam. Como afirma Naomi Klein (2002, p. 27) a marca e não a produção se tornou a atividade de lucro de nosso tempo.

Embora já estivesse protegida como direito na Convenção da União de Paris de Proteção da Propriedade Industrial de 1883, sua efetiva aplicação prática se deu de maneira lenta e gradual, ganhando importância após os anos 1940 (Klein 2002, p.30) e difundindo-se como instrumento jurídico largamente usado pelas grandes corporações na proteção de suas marcas nos anos 1970 e principalmente após o Acordo Trips (Acordo sobre os aspectos dos direitos de propriedade intelectual relacionados ao comércio Anexo 1) de 1994, acordo internacional instituído no âmbito da Rodada Uruguai que criou a Organização Mundial do Comércio (OMC).

Procurando as justificativas jurídicas da proteção das marcas, Figueiredo (2014) aponta duas escolas norte-americanas. Para a Escola de Chicago a marca deve ser protegida porque reduz o custo dos consumidores na busca de produtos, facilitando a identificação do produto, constrói e reputação da empresa e as encoraja a investirem em 
qualidade, gerando em consequência eficiência do mercado. Apresenta contraposição a esta justificativa ao apontar estudos no sentido de que investimento em marca nem sempre significa melhora do produto. Em voga nos anos 1980, decisões judiciais norteamericanas seguiram nesse sentido.

Posner e Landes (2003) exemplificam ${ }^{5}$ :

\begin{abstract}
"Suponham - reconhecidamente um exemplo atual de uma era do café gourmet - que você prefira o café descafeinado da General Foods. Se a marca da General Foods não tivesse um nome, então para pedi-lo em um restaurante ou em um supermercado você teria que pedir pelo 'o café descafeinado fabricado pela General Foods'. Isto leva mais tempo para falar, demanda mais memória de você, e demanda do atendente a ler e lembrar mais do que se você simplesmente pedir pelo 'Sanka'. O problema seria ainda mais sério se a General Foods fabricasse mais de uma marca de café descafeinado - como de fato produz. O benefício de se dar um nome de marca é então análogo daquele para designar pessoas pelo seu nome em vez de descrevê-las" (POSNER E LANDE, 2003, p. 167).
\end{abstract}

A outra escola, no estudo de Figueiredo (2014, p. 31), é a Escola de Harvard, para quem a ideia de geração de qualidade dos produtos em virtude da publicidade é falsa, "na medida em que os produtos efetivamente diferenciados são complexos e apresentam uma série de funcionalidades alheias ao conhecimento do consumidor, a este resta confiar em uma pretensa ideia de qualidade veiculada pela publicidade em torno de um produto" e se torna também uma barreira à entrada de novos concorrentes.

A proteção do consumidor, o embasamento no direito de concorrência contra atos de comércio desleal e o próprio direito à propriedade (a marca é uma propriedade, embora intelectual como observamos) fundamentam, enfim, o que se denomina especificamente pelos profissionais do ramo de Direito Marcário.

Uma empresa, ao elaborar uma marca, seja para a própria empresa seja para os seus produtos, elabora uma marca nominativa (palavra, termo, expressão) ou uma marca figurativa (desenho, logo, símbolo) ${ }^{6}$ e deve registrar no escritório competente de

\footnotetext{
${ }^{5}$ Tradução do autor. No original: "Suppose - admitely a rather dated example in this era of gourmet coffee - that you happen to prefer decaffeinated coffee made by General Foods. If General Foods brand had no name, then to order it in a restaurant or grocery store you would have to ask for 'decaffeinated coffee made by General Foods'. This takes longer to say, requires you to remember more, and requires the waiter or clerky to read and remembre more than if you can just ask for 'Sanka'. The problem would be even more serious if General Foods made more than one brand of decaffeinated coffee - as in fact it does. The benefit of the brand name is thus analogous to that of designating individuals by names rather then by description.

${ }^{6}$ Em alguns países se permite o registro de marca sonora e de fragrâncias. Nos Estados Unidos o rugido do leão da empresa cinematográfica MGM (Metro Goldwyn Mayer) é uma marca sonora registrada. No Brasil
} 
propriedade industrial. No caso do Brasil, o conhecido INPI, Instituto Nacional de Propriedade Industrial, com sede no Rio de Janeiro. No caso dos Estados Unidos, se registra no USPTO (United States Patent and Trademark Office) ou, em tradução livre, Escritório de Patentes e Marcas dos Estados Unidos. No caso da China, no Chinese Trademark Office. O registro da marca tem a validade em geral de dez anos podendo ser renovada indefinidamente. Ao receber o pedido de registro o órgão competente analisa se a marca não se confunde com outra marca anterior já registrada e se ela tem um caráter distintivo suficiente para diferenciar o produto. Não se pode registrar como marcas nomes comuns, ou do acervo do uso comum. Não se poderia, por exemplo, registrar uma marca “água" ou nomes próprios como "São Paulo". Deferido ou não o registro, a decisão é passível de recurso, seja na própria esfera administrativa seja na esfera judicial. Pode-se também registrar a marca em países estrangeiros.

O Direito de marca (direito do uso, licenciamento, reprodução) extrapolou os produtos e empresas e está impregnado na vida das pessoas e dos processos produtivos. Como vários outros instrumentos jurídicos, principalmente os voltados para as políticas urbanas, tem tido uma grande importância no delineamento das configurações das paisagens urbanas. Assim, classificado como direito de propriedade intelectual, o direito de marca não deixa também de ser uma norma de conteúdo (legislação) urbano, bastando para essa assertiva se mencionar como exemplo a lei da Cidade Limpa no Município de São Paulo (Lei Municipal 14.223 de 26/09/2006, que dispõe sobre “ordenação dos elementos que compõe a paisagem urbana do Município de São Paulo”, da gestão do prefeito Gilberto Kassab) que ao vetar o uso de outdoors de publicidade e restringir o tamanho dos anúncios publicitários nos estabelecimentos comerciais, acabou por atingir e limitar o próprio direito de uso da marca. Para Raquel Rolnik (1999), em estudo da Cidade de São Paulo, em trecho introdutório em que fala das cidades em geral:

\footnotetext{
"Mais além do que definir formas de apropriação do espaço permitidas ou proibidas, mais do que efetivamente regular a produção da cidade, a legislação urbana age como marco delimitador de fronteiras de poder. A lei organiza, classifica e coleciona os territórios urbanos, conferindo significados e gerando noções de civilidade e cidadania diretamente correspondentes ao modo de vida e à micropolítica familiar dos grupos que estiveram mais envolvidos em sua formulação. Funciona, portanto,
}

o INPI negou o registro do som "plim-plim” para a Rede Globo alegando ausência de marca sonora em nossa legislação, registrando-o como caráter visual. Embora aceite marcas sonoras, o escritório europeu de propriedade industrial negou o pedido da Globo por ser um som comum, banal, sem distintividade. 
como referente cultural fortíssimo na cidade, mesmo quando não é capaz de determinar sua forma final" (ROLNIK, 1999, p. 13).

No plano do direito, observamos desde os anos de 1980 ao lado do aumento da importância da marca na economia das grandes corporações um aumento e um recrudescimento da legislação de propriedade intelectual em todo o mundo. As primeiras legislações internacionais de propriedade intelectual se deram ao final do século XIX logo após a consolidação das revoluções industriais, com a Convenção de Paris de proteção da propriedade industrial de 1883 e com a Convenção de Berna de Direitos autorais de 1886. Quase cem anos depois se observou uma retomada do espírito de proteção dos conhecimentos tecnológicos com uma nova legislação, denominada global, que culminou com o Acordo Trips em 1994.

O Direito das Marcas $^{7}$ acompanhou esse movimento instituindo novas proteções aos titulares de direitos, com o fim de se garantir uma proteção mais eficaz e mais abrangente territorialmente. Dentre essas proteções citamos a proteção do "tradedress”, o princípio da diluição da marca, a da marca de alto renome e do impedimento do “aproveitamento parasitário".

$\mathrm{O}$ “trade-dress” consiste na proteção não apenas da marca em si, mas de sua combinação de cores e suas figuras. O surgimento de marcas e logotipos novos de empresas concorrentes que lembram marcas conhecidas levou a uma extensão da proteção com o objetivo de cercear a concorrência que se entende desleal. Não se pode usar uma combinação de cores ou de figuras que lembre, ainda que vagamente, uma marca concorrente. Protege-se, como diz o nome em inglês, a "roupagem" da marca.

Instituiu-se ainda o conceito de "diluição da marca" em que, embora um concorrente não use o mesmo nome, usa-se um nome parecido ${ }^{8}$. Quando uma empresa ao lançar um produto utiliza, em uma nova marca, cores, formas ou palavras que remetam, de forma indireta, a um produto de mesma categoria já existente no mercado, diz-se que a reprodução, ainda que não semelhante, faria a marca anterior perder a sua originalidade, causando-lhe uma diluição de seu poder comercial. Proíbe-se assim a criação de novas

\footnotetext{
${ }^{7}$ Algumas de suas outras denominações são: Direito Marcário, Direito de Marcas e Patentes e Direito de Propriedade Industrial, que são mais específicas e Direito de Propriedade Intelectual como denominação mais genérica que engloba ainda os direitos autorais.

${ }^{8}$ Tornou-se famoso o caso em São Paulo, por exemplo, em que uma lanchonete da favela de Heliópolis pintou o nome "MecFavela", e foi instada judicialmente a repintar e mudar o nome do estabelecimento. Embora se admita que nenhum consumidor pudesse ser enganado porque obviamente a lanchonete não é da rede americana, se entende, através da teoria da diluição, que a "vulgarização da marca" deixaria a marca original com sua força "diluída".
} 
marcas que possam fazer lembrar indiretamente marcas já existentes no mercado com o objetivo de preservar a força de cada marca.

A proteção da marca se dá por categorias de mercadorias. A Organização Mundial da Propriedade Intelectual, pelo setor de marcas, estabelece 45 classes de produtos, que são reproduzidas pelos órgãos de proteção da propriedade industrial dos respectivos países membros. Por exemplo, na classe um ficam protegidas as marcas de substâncias químicas destinadas à indústria, às ciências, a fotografia, assim como à agricultura, à horticultura, e à silvicultura; resinas artificiais não processadas, matérias plásticas não processadas; adubo, fertilizantes, composições extintoras de fogo e para sua prevenção, etc (vide anexo 1).

Como regra geral, as marcas registradas têm proteção apenas para sua classe de produtos. Assim existe concomitantemente no Brasil, por exemplo, a marca "Veja" do produto de limpeza, na classe 3 destinada à proteção das marcas de produtos de limpeza e higiene doméstica humana e veterinária, bem como os produtos de perfumaria, de toucador e cosméticos, e a Revista "Veja", classificada na classe 11, destinada aos jornais, revistas e periódicos. A coexistência das duas marcas se dá porque se tratam de mercadorias de classes distintas.

Essa regra, porém, tem sido excepcionada, cada vez mais, pela existência de marcas que são classificadas como marcas de alto renome. Tratam-se de marcas que teriam atingido junto ao mercado consumidor uma tal notoriedade que seu uso é monopólio da empresa detentora de maneira absoluta, em todas as categorias de mercadorias, de modo que mesmo para produtos de classe diferentes o uso de nome ou signo semelhante está proibido. São marcas de alto renome no Brasil por exemplo, as marcas "Fusca", "Barbie", "Honda", "Sonho de Valsa", "Coca-Cola", "Shell”, etc. Em face deste reconhecimento concedido pelo INPI, não poderia uma fabrica de instrumento musical registrar uma marca "Sonho de Valsa" para um violino (da classe 15) mesmo que a marca "Sonho de Valsa" se refira a um doce (da classe 33).

Já a teoria do "aproveitamento parasitário" impede que se use uma nova marca para um novo produto semelhante ou parecida a uma outra já estabelecida. Proíbese assim que o empresário se aproveite de um nome famoso para alavancar sua nova marca. Pensemos por exemplo em um motel que usaria a marca Chandon, aproveitandose da marca de espumantes Moet \& Chandon ${ }^{9}$. Embora de classes distintas e embora a

\footnotetext{
${ }^{9}$ Caso real julgado pelo Tribunal Regional Federal da 2a Região, apelação cível 97.02.23073-0, Relator Sérgio Schwaitzer.
} 
"Moet \& Chandon" não seja uma marca de alto renome, trata-se de uma marca "notoriamente conhecida", o que leva à conclusão que a empresa administradora do motel estaria se aproveitando parasitariamente de um nome, cuja fama foi construída com tempo e investimento pelo detentor original.

São, portanto, proteções jurídicas de palavras, figuras e cores que criam monopólios e reservas no uso dessas expressões em prol das grandes empresas que investem grandes somas de recursos em suas marcas, com afetação direta na concorrência e assim nas publicidades e anúncios da paisagem urbana. A repercussão espacial das marcas nos parece, aqui, óbvia. 


\section{Capítulo 3}

\section{A marca como instrumento econômico}

Inicialmente temos que buscar a origem da marca na própria noção de produto, eis que a marca estampa um produto da fabricação humana, a mercadoria. Para Marx (2004), no modo de produção capitalista quanto mais o trabalhador produz, mais ele fica pobre, pois quanto mais produz, mais produto é passado à riqueza do dono do meio de produção e ele, trabalhador, mais se distancia do fruto de seu trabalho, no sentido que ele produz um objeto que é uma exteriorização de seu trabalho mas que passa a ser incorporado pela realidade objetiva do qual ele próprio é despojado. O trabalhador se torna também uma mercadoria. Desse distanciamento do produto do seu trabalho que Marx chama de "estranhamento" (MARX, 2004, p. 82) decorre o seu conceito de alienação.

Para Marx (2013, p.146) a mercadoria tem um caráter fetichista, uma vez que ela não é apenas uma coisa "óbvia, trivial" como aparenta à primeira vista, tendo apenas um valor de uso. A mercadoria tem também um caráter místico, enigmático, misterioso, que consiste para Marx (2013):

"simplesmente no fato de que ela reflete aos homens os caracteres sociais de seu próprio trabalho, como propriedades sociais que são naturais a essas coisas e por isso, reflete também a relação social dos produtores com o trabalho total como uma relação social entre os objetos, existente à margem dos produtores. É por meio desse quiproquó que os produtos do trabalho se tornam mercadorias, coisas sensíveis-suprassensíveis ou sociais" (MARX, 2013, p. 147).

A marca tem como função impulsionar o consumo e, do ponto de vista da ciência econômica há razões para consumir ou não consumir. Para Keynes há fatores objetivos e fatores subjetivos na propensão ao consumo. Para ele o consumo guarda uma clara relação com a renda decorrente do emprego, que é o nível dos salários (1970, p. 94):

O montante que a comunidade gasta em consumo depende evidentemente: 1) em parte do montante da sua renda, 2) em parte, de outras circunstâncias objetivas que o cercam, e 3) em parte, das necessidades subjetivas, inclinações psicológicas e hábitos dos indivíduos que a compõem, bem como dos princípios que governam a distribuição de renda entre eles (que podem variar conforme a produção aumenta) (KEYNES (1970, p. 94). 
E como esses fatores estão relacionados, o autor passa a enumerar os fatores objetivos e os fatores subjetivos (KEYNES, 1970, p. 95). Dentre os objetivos se encontram: (1) variações na unidade de salário, (2) variações na diferença entre renda e renda líquida, (3) variações imprevistas nos valores de capital não considerados no cálculo da renda líquida, (4) variações na taxa de desconto temporal (relação de troca entre bens presentes e bens futuros), (5) variações na política fiscal, e (6) modificações das previsões acerca da relação entre os níveis presentes e futuro da renda. Para nosso estudo mais especificamente, mais importante, porque voltamos para a questão do papel da marca no impulso do consumismo, são os fatores subjetivos. Keynes (1970, p. 109) elenca fatores subjetivos para não gastar, não consumir: (1) constituir uma reserva para atender contingências imprevistas, (2) necessidades futuras, (3) beneficiar-se do juro e da mais valia, (4) desfrutar de um gasto progressivamente crescente, (5) desfrutar de uma sensação de independência, (6) garantir massa de manobra para projetos especulativos ou econômicos, (7) legar fortuna, (8) satisfazer a pura avareza. O autor traduz então como:

Estes oito motivos podem ser chamados de: Precaução, Previsão, Cálculo, Ambição, Independência, Iniciativa, Orgulho e Avareza; também poderíamos formular uma lista de motivos para consumir, tais como: Desejo de gozar, Imprevidência, Generosidade, Irreflexão, Ostentação e Prodigalidade. (KEYNES, 1970, p. 110).

A marca dos produtos tem sua importância, indubitavelmente, no fator elencado como desejo de gozar, e mais acentuadamente em nossos dias, na ostentação. Como assevera Klein (2002), a marca virou símbolo de status social. Partindo de exemplos de campanhas publicitárias nos anos 1970 e início de 1980, Klein (2002, p. 52) afirma que "Até o início dos anos 70, os logotipos em roupas geralmente ficavam escondidos, discretamente colocados na face interna dos colarinhos", sendo as exceções nos uniformes do golfe e do tênis, esportes de ricos. Nos anos 1970, então, a marca passa por uma grande transformação, passando, pelo processo denominado de "branding" a se imiscuir na cultura e se expandindo: "Se as marcas não são produtos, mas conceitos, atitudes, valores e experiências, por que também não podem ser cultura ?” (KLEIN 2002, p. 54). 
O direito de marca, como vemos, originalmente, foi instituído após a revolução industrial, mais propriamente com a produção em larga escala das mercadorias através do processo manufatureiro.

A instituição de uma marca cria uma espécie de monopólio, na medida em que ao incentivar seu consumo através da publicidade, acaba por ganhar uma fatia de mercado próprio em que apenas a dona da marca ou uma empresa que pague uma licença poderá explorar.

Klein (2002) ao buscar as origens da marca no período posterior à segunda guerra mundial, quando o consumismo atingiu as classes médias, portanto um espectro muito maior da população, faz uma distinção entre a marca e a publicidade, ressaltando que os seus processos são diferentes:

"A publicidade de qualquer produto é apenas uma parte do grande plano de branding, ou gestão de marca, assim como o patrocínio e o licenciamento do logotipo. Pense na marca como o sentido essencial da corporação moderna, e na publicidade como um veículo utilizado para levar esse sentido ao mundo" (KLEIN, 2002, p.29).

A marca chega assim aos nossos dias como o mais poderoso instrumento empresarial. A propriedade de marcas registradas aumenta o ativo das empresas e entram nos valores das empresas na hora das fusões e aquisições. O registro de novas marcas nos escritórios de propriedades industriais dos países é, assim, revelador do dinamismo econômico, uma vez que é um de seus instrumentos de medição. Mais marcas significam mais produtos novos lançados nos mercados. Vemos na tabela abaixo (tabela 1) o registro de marcas empresariais junto aos escritórios de propriedade industrial dos respectivos países e colhidos pela Organização Mundial da Propriedade Intelectual (OMPI) de quatro países. Embora não sejam objeto do presente estudo, mostramos os números também de Japão e Brasil, por representarem, respectivamente, um país do desenvolvido e outro em desenvolvimento para análise comparativa de Estados Unidos e China. A adoção do Brasil acaba servindo também para confirmar a existência aqui de uma economia diversificada, com uma quantidade razoável de marcas (oferecimento de produtos e serviços) quando comparada aos demais países, mas sem inovação, quando percebidos os registros de patentes, bem menor na comparação com os demais países, como se verá. 
Tabela 1. Totalidade de pedidos de registros de marcas em cada país por ano ${ }^{10}$.

\begin{tabular}{|c|c|c|c|c|}
\hline Ano/País & EUA & Japão & China & Brasil \\
\hline 2000 & 624.363 & 167.668 & & \\
\hline 2001 & 459.416 & 172.116 & & \\
\hline 2002 & 429.790 & 148.168 & 331.727 & 85.544 \\
\hline 2003 & 461.118 & 165.313 & 417.238 & 88.977 \\
\hline 2004 & 585.749 & 187.007 & 551.005 & 88.236 \\
\hline 2005 & 649.967 & 194.785 & 630.480 & 93.152 \\
\hline 2006 & 691.419 & 193.750 & 714.285 & 88.196 \\
\hline 2007 & 780.690 & 206.594 & 656.705 & 93.409 \\
\hline 2008 & 727.347 & 194.886 & 644.184 & 111.361 \\
\hline 2009 & 640.433 & 182.377 & 798.751 & 103.622 \\
\hline 2010 & 726.333 & 194.417 & 1054.758 & 114.244 \\
\hline 2011 & 801.745 & 198.730 & 1.373 .069 & 132.818 \\
\hline 2012 & 828.897 & 224.437 & 1.613 .209 & 131.118 \\
\hline 2013 & 871.634 & 210.635 & 1.850 .294 & 145.167 \\
\hline 2014 & 902.114 & 220.436 & 2.147 .379 & 139.010 \\
\hline 2015 & 942.962 & 225.212 & 3.100 .283 & 141.943 \\
\hline 2016 & 936.508 & 244.525 & 4.192 .656 & 147.782 \\
\hline 2017 & 1.654 .453 & 768.431 & 6.388 .344 & 178.428 \\
\hline 2018 & 1.759 .406 & 719.264 & 8.118 .135 & 195.715 \\
\hline
\end{tabular}

Fonte: Organização Mundial da propriedade intelectual. Elaboração do autor

A presença de marcas empresariais globais em todos os cantos do planeta induz à falsa percepção de certa homogeneização do espaço e mesmo de capitais. Por certo a presença das marcas e, portanto, das empresas, indica circulação e consumo. Onde há circulação há um certo dinamismo econômico, mas a circulação faz também os lugares se especializarem. Monica Arroyo (2006), fazendo referência a Camille Vallaux e Maximilien Sorre, afirma que a circulação é uma das bases de diferenciação geográfica

\footnotetext{
${ }^{10}$ Esses números são constantemente revistos pela OMPI, uma vez que pedidos deferidos em um ano podem ser excluídos depois por falta de requisitos formais ou vice-versa. Os números aqui descritos são conforme o obtido em pesquisa no site no dia 11 de fevereiro de 2018, às 00:40 h. Os números descritos para os anos de 2017 e 2018 foram obtidos no site da OMPI no dia 06 de outubro de 2020, às 2:07.
} 
uma vez que, se por um lado a circulação tende a uma certa uniformização dos lugares, por outro lado ela atua como agente de diferenciação, pois modifica os lugares, e não os anula. O capitalismo, sendo um modo de produção que tende à expansão, acaba por criar condições para que os lugares se especializem, o que leva a se estabelecer uma crescente divisão territorial do trabalho.

No caso das marcas, essa presença mercantil em uma determinada localidade não significa assim que possa ocorrer ali uma homogeneização e alguma acumulação de capital. Ao contrário, a marca capta os recursos locais e envia, via cobrança de royalties, para suas sedes, geralmente localizados no centro do sistema capitalista.

Sendo o capitalismo um modo de produção que precisa de sua constante expansão, "desigual e combinada", a marca, pelo trabalho da publicidade e da propaganda se torna um elemento chave. Milton Santos (2002, p. 146) quando fala da publicidade e das marcas, não deixando dúvida sobre a eficácia do mecanismo, afirma que "Mas é necessário reconhecer que ela ainda é o pilar de sustentação e de expansão do sistema, notadamente para a diversificação da produção, com o aumento do número de produtos similares oferecidos ao público".

Também em "Por uma outra Globalização", Milton (2001, p. 24), em capítulo denominado "O consumo e o seu despotismo", aponta essa inversão da realidade do consumo no período atual:

\begin{abstract}
"Também o consumo muda de figura ao longo do tempo. Falava-se, antes, de autonomia da produção, para significar que uma empresa, ao assegurar uma produção, buscava também manipular a opinião pela via da publicidade. Nesse caso, o fato gerador do consumo seria a produção. Mas, atualmente, as empresas hegemônicas produzem o consumidor antes mesmo de produzir os produtos. Um dado essencial do entendimento do consumo é que a produção do consumidor, hoje, precede à produção dos bens e serviços. (SANTOS, 2001, p. 24)".
\end{abstract}

Milton Santos, em seguida, afirma que o consumo é primeiro organizado para depois se organizar a produção, pelo império da informação e da publicidade. Um consumo e informação ideologizados, como motores das ações públicas e privadas, que acaba por levar a narcisismos em que o cidadão cede lugar ao consumidor.

Esse motor, em escala global, se enquadra no que Milton chama de "despotismo da informação" e "Como as atividades hegemônicas são, hoje, todas elas, fundadas nessa técnica, o discurso aparece como algo capital na produção da existência 
de todos" (SANTOS, 2001, p. 25). Busca-se, ainda segundo Milton, a "unificação do planeta".

Passadas quase duas décadas da última obra de Milton, as afirmações continuam atuais, tendo-se ainda superadas, pelas grandes empresas hegemônicas, eventuais obstáculos alfandegários, devendo ser destacado que essa unificação, certamente, não é uniforme, mas cada vez mais profundamente desigual territorialmente.

A literatura da administração de empresas nos Estados Unidos é pródiga tanto em mapear as estratégias globais das empresas transnacionais, como em indicar os caminhos de mitigar os efeitos fiscais-tributários dessas operações. Yeming Gong (2013) aponta o que os autores da área vêm destacando como os principais atributos para a atuação global das empresas nesse sentido.

Uma repercussão espacial visível dos processos de transferências de royalties é que muito embora as marcas globais estejam presentes em cidades do mundo todo, elas continuam, e têm se tornado cada vez mais, desiguais em tratando de renda per capita. Mike Davis (2006, p. 24) elaborou tabela comparativa das dez maiores cidades do mundo no ano de 2000, em que metade das maiores cidades em população se localizam em países periféricos (ou semiperiféricos na definição de Arrighi) que eram Cidade do México, São Paulo, Mumbai, Délhi e Jacarta. Já na tabela das cidades com maiores rendas per capita, todas as dez primeiras são cidades do centro dinâmico da economia (Japão, Europa e Estados Unidos). O descompasso se explica por diversas razões, como o capitalismo tardio, aumento da urbanização em condições diferenciadas, vetores globais da economia, localização em economias centrais dependentes, enfim, formações socioespaciais próprias. Nosso pressuposto é que os direitos de propriedade intelectual como um todo, aqui incluídas também a exploração de patentes, direitos autorais e o licenciamento das marcas empresariais, são um dos principais instrumentos na construção e manutenção dessa desigualdade espacial. 


\section{Capítulo 4}

\section{As marcas na reprodução do espaço}

A lógica da marca empresarial de não mais como um mero sinal distintivo, mas um sinal que deva ser incorporado como uma cultura (ou poder?) hegemônico a ser imposto adentrou também os espaços da esfera pública, submetendo todo o espaço à lógica empresarial. Para Jeudy (2005) as práticas de marketing e do processo de branding das marcas foram incorporadas pelas gestões das cidades.

De fato, a relação entre os lugares e as firmas que ali se instalam e que acabam por criar, às vezes, simbioses, é uma relação antiga. Por exemplo, na cidade de Itu, no Estado de São Paulo, existe um bairro denominado "Bairro Cinzano", e em Manaus, Capital do Amazonas, na zona leste da cidade existe uma tal "Comunidade Sharp". Como se instalam esses nomes e qual o sentido dessas denominações? Nos casos assinalados é possível que tenha havido uma apropriação pela população dos nomes das marcas das empresas para designar os lugares.

No entanto, em nossos dias, a presença da marca no território se dá de uma outra forma, menos aleatória e "inocente". Ela hoje se dá de forma planejada e retrata uma lógica empresarial em que o Estado age em benefício das empresas. São as novas políticas empresariais da era da globalização moderna, em que impera a lógica neoliberal.

As empresas, através de suas marcas, estão, por exemplo, na remodelação dos centros urbanos, ou o que na geografia urbana se denomina de "requalificação dos centros urbanos", que assumindo os "custos" da requalificação das áreas centrais, ou em parcerias público-privadas acabam por gerenciá-las, destinando ao uso privado, onde a lógica empresarial predomina. Harvey (2014, p. 146) denomina esse processo como uma nova forma de despossessão, uma acumulação primitiva dos dias de hoje:

"É deprimente pensar que tudo isso foi escrito em 1872. A descrição de Engels aplica-se diretamente ao processo de urbanização contemporâneo em grande parte da Ásia (Deli, Seul, Mumbai), bem como à gentrificação atual do Harlem e Brooklyn, em Nova York. A realização de novas geografias urbanas implica inevitavelmente o deslocamento e a despossessão. É o reflexo feio da absorção de capital por meio da reabilitação urbana" (HARVEY. 2014. p. 146).

Importante ainda destacar o papel da marca empresarial na produção do espaço. Milton Santos $(2001,2008)$ destaca o papel das firmas nos circuitos espaciais da 
produção, e assevera as mudanças havidas no período que denominamos de "globalização".

Após pelo menos três décadas de debates sobre globalização, considerado o início desse debate as primeiras formulações do termo nas escolas de administração norteamericanas nos anos 1980, ainda se mostra pertinente uma tentativa de enquadramento do termo no contexto de uma pesquisa sobre marcas empresariais no âmbito da Geografia. Faulconbridge e Beaverstock (2009) apontam o cuidado que se deve ter na leitura da globalização, tendo em vista os problemas que surgem em cada acepção do termo, tendo o seu significado e seu valor conceitual sido há muito contestado no âmbito da geografia humana.

Apoiados em Dickens, Faulconbridge e Beaverstock (2009, p. 332) sustentam que "o estudo da globalização, para o caso de geógrafos, tem como objetivo básico o de analisar os processos que moldam e remoldam o mapa do globo" ${ }^{11}$. Para os autores ao contrário de sugerir uma homogeneização, a globalização é um processo que deve ser entendido como um processo desigual no espaço e no tempo, trazendo muita diferença e diversidade para a sociedade global.

A conquista de mercados pelas empresas significa conquista de território, uma vez que mercado significa território. Para Milton Santos (1999, p 15) “os territórios nacionais se transformam num espaço nacional da economia internacional e os sistemas de engenharia mais modernos criados em cada país são mais bem utilizados por firmas transnacionais que pela própria sociedade nacional".

O que é mais notório nessa conquista é que as empresas delimitam o território conquistado fincando símbolos, que em nosso entender são as marcas visuais através da publicidade que elas fazem proliferar no espaço geográfico.

Paul Claval entende que no jogo do poder que se faz no espaço, há um simbolismo que é relevante:

\footnotetext{
"El espacio interviene de diversas maneras em la vida social y, por lo tanto, em el juego de poder: 1) es sostén de la vida y de la actividad, e interviene entonces por la extensión; 2) es obstáculo para la vida de relación; 3) sirve de base a la actividad simbólica." (CLAVAL, 1982, p. 19)
}

\footnotetext{
${ }^{11}$ Em tradução nossa. No original: Dicken (2003:1) argues that for geographers studying globalization, the basic aim is to analyse the processes shaping and reshaping the global map.
} 
As marcas empresariais são onipresentes na vida das pessoas e no cotidiano do trabalhador. Das marcas das roupas que veste o trabalhador, aos alimentos e bebidas de seu almoço, passando pelo celular com que se comunica com amigos e familiares, o automóvel com que se desloca pelas cidades, na paisagem urbana que o rodeia, impregnada de anúncios publicitários de toda ordem, a marca se tornou a representação das grandes empresas nos espaços públicos. Reflete, assim, na sua condição de vida e de reprodução.

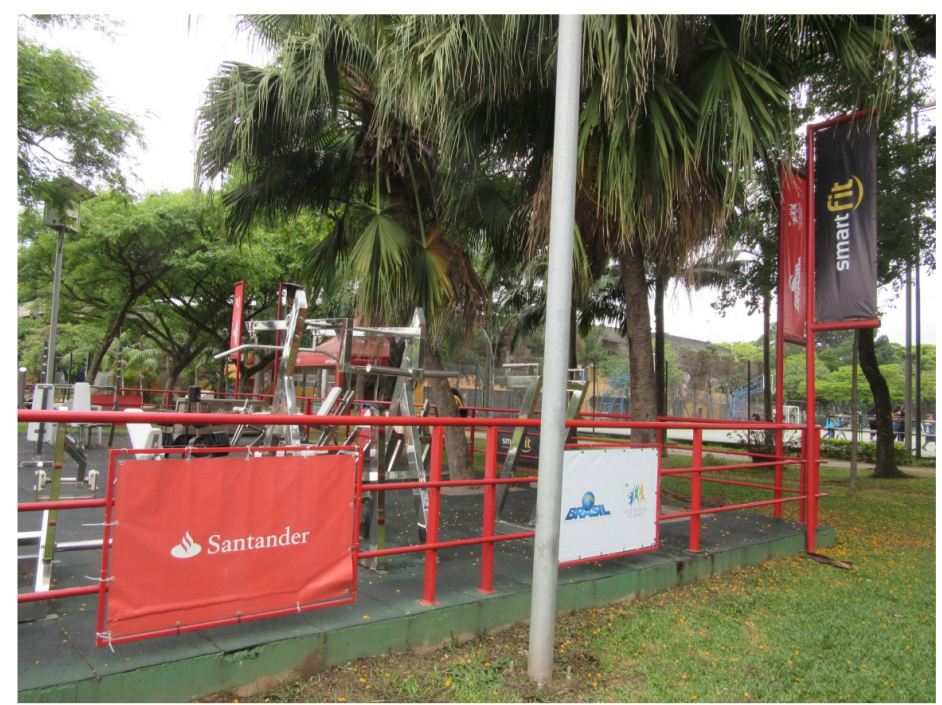

Fotografia 01. Centro de Práticas Esportivas da Universidade de São Paulo - Cepeusp - Foto tirada em 30/11/17 pelo próprio autor. Espaço patrocinado pelo Banco Santander.

Klein (2002, p. 59) denomina de "branding da paisagem urbana" esse fenômeno da apropriação dos espaços públicos pelas marcas e cita um exemplo que a partir de um caso em Los Angeles se expandiu para outros lugares do mundo:

"Se essa expansão insidiosa da publicidade parece mera questão de semântica quando aplicada a táxis e camisetas, suas implicações são muito mais sérias quando vistas no contexto de outra tendência de marketing: o branding de bairros e cidades inteiros. Em março de 1999, o prefeito de Los Angeles, Richard Riordan, revelou um plano para revitalizar as áreas pobres do centro da cidade, muitas ainda marcadas pelos distúrbios de 1992 que se seguiram ao veredicto do caso Rodney King: as corporações adotariam uma parte arruinada da cidade e 'marcariam’ sua recuperação" (KLEIN, 2002, p. 62).

Ainda para Klein (2002), essa expansão das marcas para todas as esferas da vida pública se dá ainda mediante o "branding" da mídia, em que a cultura, quando 
patrocinada, se torna mero instrumento de promoção da marca patrocinadora. Essa expansão se dá ainda na música, em que espetáculos se tornam "publicidade live action" (KLEIN 2002, p. 71), nos esportes, citando o exemplo da Nike e afirma que "Como sugerem todas essas estruturas do futuro, os patrocinadores corporativos e a cultura que eles marcam estão se fundindo para criar uma terceira cultura: um universo fechado em si mesmo de gente de grife, produtos de grife e mídia de grife" (KLEIN, 2002, p. 84).

Michael Hardt e Antonio Negri (2018) afirmam que o que presenciamos no mundo atual é a apropriação do comum pelo privado. Comum é tudo aquilo que na linguagem jurídica chamamos de domínio público. Ou seja, o domínio público, que deveria ser comum a todos, está sendo apropriado pelos agentes privados. O processo que Harvey (2012) chama de despossessão, Hardt e Negri (2018) chamam de "extração", uma exploração em larga escala. Reconhecendo que a extração sempre estivera presente no Capitalismo, na exploração dos recursos naturais, grilagens de terra, e "Como recursos materiais, também os seres humanos podiam ser extraídos e tornado propriedades pessoais móveis, e, por meio do comércio atlântico de escravos, seu valor entrava nos livros-razões dos colonizadores" (HARDT e NEGRI, 2018, p. 224), os autores afirmam que no presente momento histórico a gravidade e extensão desta extração é muito maior. Em primeiro lugar “(...) é a dramática expansão das fronteiras do extrativismo. Nenhum canto da Terra está livre dele" e "Os efeitos destrutivos do extrativismo são elevados exponencialmente pela perspectiva de mudança climática" (HARDT e NEGRI, 2018, p. 226).

Mas sobretudo a extensão do que se apropria é uma outra significativa diferença das expropriações das fases anteriores do Capitalismo: "Contudo, para entender o extrativismo contemporâneo, é preciso reconhecer não só o valor arrancado da terra, mas também, como dissemos, o valor capturado da outra ampla categoria do comum: as muitas formas de vida e de produção sociais” (HARDT e NEGRI, 2018, p. 227)

Thomas Piketty, que faz uma análise do "Capital no Século XXI" (PIKETTY, 2014), ao descrever o que chama de riqueza nacional como a soma da riqueza privada com a riqueza pública, afirma que hoje, ao contrário do passado a riqueza pública é bem menor na maior parte dos países desenvolvidos, e que "a riqueza privada representa quase a totalidade da riqueza nacional em quase todos os países' (PIKETTY, 2014, p. 54). O autor assevera que:

"Incluímos, além disso, o capital 'imaterial', como por exemplo, as patentes e outros direitos de propriedade intelectual, tratados como 
ativos não financeiros (se os indivíduos detêm diretamente as patentes) ou como ativos financeiros, quando as entidades privadas detêm ações de empresas que são proprietárias das patentes - o que, aliás, é o mais comum. De modo geral, as várias formas de capital imaterial são levadas em conta por meio da capitalização das empresas no mercado de ações. Por exemplo, o valor de mercado de uma empresa depende, muitas vezes, de sua reputação e da reputação de suas marcas, de seus sistemas de informação e de suas formas de organização, dos investimentos materiais e imateriais que realizam para adquirir visibilidade e atratividade para o que produzem (bens e/ou serviços), além de depender, também, dos gastos em pesquisa e desenvolvimento etc. Tudo isso se reflete nos preços das ações e dos outros ativos das empresas, e, portanto, no valor da riqueza nacional" (PIKETTY, 2014, p. 54-55).

Das análises que podemos fazer a partir dos dados quantitativos que extraímos dos registros de patentes, observamos um aumento da propriedade intelectual nas empresas e diminuição de patentes no setor público. Muito embora haja ainda muita atividade inventiva nas universidades públicas, o fruto dessa atividade vai, via patentes e marcas, desembocar nas mãos das empresas, fenômeno observável também na China, entre os anos 2012 e 2018 (tabelas 16 e 17). Essa migração de valores do setor público para as empresas, realizado pelo mecanismo dos direitos de propriedade intelectual, se constitui também em objetivo da presente tese. 


\section{Capítulo 5}

\section{A Geopolítica da marca empresarial.}

A defesa da marca no exterior se tornou uma necessidade dos empresários em um mundo global altamente conectado pela publicidade via internet, alcançado territórios de outros países. A marca registrada é uma das únicas (ao lado das indicações geográficas) propriedades intelectuais que não caem em domínio público após determinado período de tempo (patentes duram vinte anos, direitos autorais setenta anos após a morte do autor, etc). Desde que o dono da marca comprove seu uso e promova a renovação do pedido ao final do prazo de registro (em geral de 10 anos), o empresário poderá usá-lo indefinidamente. Embora as marcas passem por remodelação de layout em suas formas figurativas, as marcas resistem no tempo e se tornam valores das empresas, diferenciandoas no mercado. Essa preocupação tem se acentuado muito nos últimos anos com a adesão cada vez maior dos países aos tratados de registros internacionais, como o Tratado de Madri, em que Estados Unidos e China já eram signatários e que, exemplificativamente o Brasil aderiu no ano de 2019.

Os registros de marcas no estrangeiro são um bom demonstrativo da internacionalização das empresas de um determinado país, pois se uma empresa registra uma marca em um país, significa que explora comercialmente o mercado daquele país, ou que vai explorá-lo em um futuro próximo. Tanto porque o registro impõe custos elevados, como pelo fato de se a empresa deixar de usar a marca por cinco anos, a empresa perderá o direito da marca. Portanto, registro de marca em um país estrangeiro significa atuação no mercado daquele país. Nesse sentido, observamos, por exemplo, quando comparados com o quadro da Tabela 1, de registros de marcas nos países, que os Estados Unidos registram uma maior quantidade de marcas no exterior que no próprio país (Tabela 2). Tem, portanto, muitas empresas americanas atuando no exterior.

Tabela 2 - Pedidos de registros de marcas por chineses ou empresas chinesas no exterior e de americanos ou empresas americanas no exterior

\begin{tabular}{l|l|l|l|l}
\hline & $\begin{array}{l}\text { Pedidos de } \\
\text { registros de } \\
\text { americanos no } \\
\text { exterior }\end{array}$ & $\begin{array}{l}\text { Registros } \\
\text { obtidos por } \\
\text { americanos no } \\
\text { exterior }\end{array}$ & $\begin{array}{l}\text { Pedidos de } \\
\text { registros de } \\
\text { Chineses no } \\
\text { exterior }\end{array}$ & $\begin{array}{l}\text { Registros } \\
\text { obtidos por } \\
\text { Chineses no } \\
\text { exterior }\end{array}$ \\
\hline 2009 & 760.090 & $906.380^{*}$ & 96.260 & 82.325 \\
\hline 2010 & 903.596 & 935.442 & 139.532 & 126.963 \\
\hline
\end{tabular}




\begin{tabular}{l|l|l|l|l}
\hline 2011 & 1.016 .289 & 880.807 & 172.015 & 152.585 \\
\hline 2012 & 1.060 .532 & 932.388 & 191.344 & 152.681 \\
\hline 2013 & 1.144 .074 & 1.011 .156 & 207.451 & 196.808 \\
\hline 2014 & 1.163 .455 & 1.004 .595 & 282.017 & 195.911 \\
\hline 2015 & 1.289 .434 & 1.190 .693 & 401.032 & 301.118 \\
\hline 2016 & 1.219 .020 & 1.089 .338 & 665.703 & 501.223 \\
\hline 2017 & 1.226 .229 & 1.179 .186 & 849.259 & 673.555 \\
\hline 2018 & 1.313 .534 & 1.179 .186 & 990.944 & 836.120 \\
\hline
\end{tabular}

Fonte: Organização Mundial da Propriedade Intelectual - OMPI - Elaboração do autor

*Registros obtidos devem ser inferiores aos registros pedidos, mas no caso, por óbvio, foram obtidos registros sob análises pedidos em anos anteriores.

$\mathrm{Na}$ China existem hoje um total de 7 milhões de marcas registradas (concedidas) sendo que $10 \%$ são de propriedade de estrangeiros, o que demonstra uma diversidade de produtos nacionais e predominância da indústria nacional no mercado interno.

\subsection{As grandes transações de marcas}

É de se questionar inicialmente a razão das grandes empresas terem o cuidado de registrarem as marcas de suas empresas e de seus produtos nos países estrangeiros. Para Graeme W. Austin (p. 1) a mente humana não é uma coisa confinada geograficamente, e os recursos e informações que formam a consciência humana não começam e não se encerram nas fronteiras de uma nação. A força de uma marca e sua penetração depende da absorção da mente humana. Dado que a economia internacional moderna é constituída por muitas empresas transnacionais, detentoras de muitas marcas famosas internacionalmente, conclui-se pela importância do registro das marcas, para sua proteção contra a concorrência desleal em um espaço cada vez mais globalizado.

Nesse sentido o enquadramento jurídico da propriedade intelectual é global e atinge direta ou indiretamente todos os países. No âmbito da Organização Mundial do Comércio, vigoram dois princípios que desconsideram a diferença de estágio tecnológico e peculiaridades de cada país membro, levando a uma padronização que, a nosso ver, prejudica os países ainda não desenvolvidos. Os artigos $3^{\circ}$ e $4^{\circ}$ do acordo Trips são um claro exemplo dessa desconsideração. $\mathrm{O}$ artigo $3^{\circ}$ estabelece que que os países membros 
não concedam às pessoas nacionais dos demais países tratamento menos favorável que aos seus próprios. $\mathrm{O}$ artigo $4^{\circ}$ estabelece que o privilégio ou imunidade que um país membro der às pessoas de outro país membro fica automaticamente outorgado a todas as pessoas dos demais países membros. São os chamados, respectivamente, os princípios do "tratamento nacional" e da "nação mais favorecida". Ou seja, proíbem que se conceda benefícios de direitos de propriedade intelectual a países em estágios menos avançados de desenvolvimento tecnológico, por exemplo, ou favoreça os residentes de seu próprio país, tornando impossível medidas de caráter protecionista, por exemplo.

É preciso observar aqui que, ao contrário de outros tratados ou convenções internacionais, a adesão à $\mathrm{OMC}$ se dá somente mediante a aceitação da regra do "single undertaking" e do "enforcement". A primeira regra não permite ao país aderente fazer reserva de alguns princípios ou $\operatorname{artigos}^{12}$. Ou seja, ou acolhe o Tratado inteiro ou não entra na Organização. E ainda se obriga a fazer valer internamente toda a legislação do tratado.

Esse tratamento jurídico global e o esforço dos organismos internacionais em sua efetiva aplicação é o resultado, em grande medida, da pressão dos países desenvolvidos em seu esforço de garantir a hegemonia de suas empresas e dar alguma segurança nas transações das grandes corporações relacionadas às suas marcas. Essas transações surpreendem pelas vultosas somas de valores envolvidas.

A revista Exame da Editora Abril, através de seu site ${ }^{13}$, anunciou em 13 de dezembro de 2016 que, com o fim de se facilitar a efetivação da compra da cervejaria SABMiller junto aos órgãos europeus de regulação concorrencial, uma vez que há limitação na constituição de oligopólios, a AB InBev vendeu cinco marcas de cerveja pertencentes à SABMiller para a companhia japonesa Asahi. São marcas da República Checa, Polônia, Hungria, Eslováquia e Romênia. O valor das cinco marcas foi estipulado em 7,3 bilhões de euros ${ }^{14}$.

A Unilever anunciou a venda de algumas marcas de alimentos, incluindo a de margarina e manteiga (flora e stork) por US\$ 7,4 bilhões de dólares ${ }^{15}$. Não se duvida que a fabricação de margarina ou manteiga seja uma operação bastante simples, em que

\footnotetext{
${ }^{12}$ Fazer reserva em direito internacional é quando um país adere a um tratado, mas diz expressamente que não acolhe um ou outro artigo desse tratado.

${ }^{13}$ Disponível em: http://exame.abril.com.br/negocios/ab-inbev-vende-5-marcas-de-cerveja-para-asahipor-e-73-bilhoes/. Acesso em 04/04/17

${ }^{14}$ Nesta data (04/04/17, câmbio 3,22) equivale à importância de $\mathrm{R} \$ 23.506 .000 .000,00$.

15 Disponível em: http://oglobo.globo.com/economia/unilever-prepara-venda-de-marcas-de-alimentospor-us-744-bilhoes-21083727. Acesso em 04/04/17.
} 
qualquer outro concorrente, em vez de comprar as marcas, simplesmente poderia iniciar a fabricação com uma nova marca diferente. A importância da marca já consolidada, assim, é patente.

Também no Brasil, a lógica é a mesma. O Jornal O Valor Econômico de 31 de março de $2017^{16}$ informa que o Banco Original vendeu sua própria marca para o controlador, a J\&F Investimentos, holding que controla também a empresa de carnes JBS, pela importância de 422 milhões de dólares. Neste caso a intenção teve motivação contábil. Como a manutenção da marca envolve gastos com publicidade para mantê-la ativa e atraente, no caso no varejo bancário, o Banco vendeu a marca para que deixasse de ter essas despesas de marketing, no montante em 2016 de 140 milhões de reais. Ou seja, aqui se objetivou "arrumar" a contabilidade do banco e repassar a despesa ao controlador. Por essa razão que a venda se deu para agente do mesmo grupo econômico.

As batalhas pelas conquistas de mercados através das marcas não se fazem sem o efetivo apoio dos estados nacionais às suas empresas. No âmbito da Organização Mundial do Comércio os estados membros atuam na defesa dos interesses privados de seus nacionais. Os Estados Unidos abriram, em 10 de abril de 2007 um painel, denominação institucional para litígio, contra a China por infrações contra as propriedades intelectuais das empresas americanas, especificamente referentes às marcas empresariais e direitos autorais ${ }^{17}$. O litígio que recebeu o número DDS362 consistia na acusação dos Estados Unidos de que a China infringia 4 pontos da legislação mundial da matéria: 1) Que a China não criminalizava atos de falsificação e pirataria de marcas empresariais e de direitos autorais; 2) que as autoridades chinesas não promoviam a eliminação dos produtos falsificados confiscados; 3) que o escopo de criminalização das infrações de direitos autorais na distribuição e reprodução era de pouco alcance e 4) que a China não protegia direitos autorais e conexos na divulgação de obras e conteúdos distribuídos, gravados ou reproduzidos no território chinês.

Diversos outros países entraram na disputa como terceiros interessados. Argentina, Austrália, Brasil, Canadá, a Comunidade Europeia, Índia, Japão, Coreia do Sul, México, Formosa, Tailândia e Turquia integraram a disputa nessa condição. Após defesa e uma série de debates, em 13 de abril de 2010 o governo chinês apresentou a

\footnotetext{
16 Disponível em: http://www.valor.com.br/financas/4921728/banco-original-vende-marca-aos-propriosdonos. Acesso em 04/04/17.

17 Disponível em: https://www.wto.org/english/tratop_e/dispu_e/cases_e/ds362_e.htm. Acesso em 24/04/2018.
} 
informação de que o $11^{\circ}$ Congresso Nacional do Povo aprovou emenda na lei de direitos autorais para adotar medidas recomendadas pelo painel que diminuam os problemas alegados pelos Estados Unidos.

Para Noam Chomsky (2017), os Estados Nacionais são importantes atores no comando do mundo, mas retoma Adam Smith que denominava os industriais e comerciantes da Inglaterra como os "Mestres da Humanidade". Para Chomsky (2017, p. 297) os "mestres" de nossa era são os conglomerados multinacionais, gigantescas instituições financeiras e impérios de varejo.

Ainda para Chomsky $(2017)^{18}$ :

"Na ordem global contemporânea, as instituições dos mestres detêm um poder enorme, não apenas na arena internacional, mas também em seus próprios Estados de origem, em que se fiam para proteger o seu poder e para fornecer apoio econômico mediante uma grande variedade de meios. Quando consideramos o papel dos mestres da humanidade, nós nos voltamos para tal tipo de prioridade das políticas estatais do momento, caso do Acordo de Associação Transpacífico, um dos tratados que visam tutelar e ampliar os direitos dos investidores e que são equivocadamente rotulados, na propaganda e nos comentários, de "acordos de livre comércio" (CHOMSKY, 2017, p. 298).

\section{2 - A Geopolítica das marcas de águas minerais}

Se entre as possíveis leituras do que seja o objeto de estudo da Geografia se encontra aquela que responde como sendo o estudo da paisagem terrestre, nada mais imperativo que voltar o olhar, em um estudo da Geografia, para a água, seu componente mais valioso e explicativo da vida. A ênfase sobre esse recurso natural é dada por um de nossos maiores clássicos, Jean Brunhes (1962), já em 1910:

\footnotetext{
"Nas zonas da sede, nas regiões pobres em água, é que se compreende a imperiosa subordinação dos homens à água. Aqueles homens que parecem ser os mais independentes das condições locais e que escapam ao aprisionamento geográfico de nossa vida sedentária, os nômades, os grandes pastores, não fogem à tirania das águas: todas as suas trilhas, todos os seus itinerários, todas as suas incursões devem, antes de tudo, levar em conta os pontos de água, o reabastecimento de água permanece sendo o mais constante e o mais grave de todos os problemas quotidianos" (BRUNHES, 1962, p. ).
}

\footnotetext{
${ }^{18}$ O Tratado Transpacífico acabou sendo assinado no início do ano de 2018 sem a adesão dos Estados
} Unidos, após decisão do Presidente Donald Trump de retirar o país do acordo. 
Dentre nós também não faltou quem dissertasse sobre a importância da água. Josué de Castro, em capítulo sobre a área amazônica em sua emblemática obra, quando menciona as populações que vivem nas margens dos rios, ressalta que:

"É verdade que aí vivem quase todos os habitantes da Amazônia, pouca gente se aventurando a afastar-se da beira da água, desde que não há, afora os rios, outro meio de penetração na floresta, e ainda porque é na água dos rios que se concentram as maiores riquezas econômicas para sua subsistência" (CASTRO, 1984, p. 60).

O excesso de água pode ser, inversamente a sua falta, também um problema, como o é, muitas vezes, na Amazônia, cujas inundações, as chamadas "enchentes grandes" atrapalham a vida das pessoas e de suas culturas levando a "um dos mais graves fatores de desequilíbrio social da região. Há quem compare seus flagelos com os da seca dos sertões nordestinos. Flagelados por falta d’água. Flagelados por excesso d’água (Castro, 1984, p. 61).

Josué de Castro observava como uma das consequências do desflorestamento da região nordeste (e também nas regiões de cafezais em São Paulo) um problema grave na formação das reservas subterrâneas de água: “Água que é indispensável ao equilíbrio da vida regional, evitando que a região entre em decadência. Já hoje as terras nordestinas estão a exigir, por toda parte, a irrigação constante, a fim de que a cana continue a produzir em forma compensadora" (Castro, 1984, p. 116).

Desnecessário, assim, a continuação de se asseverar a importância da água para a vida humana. E passamos então a enfrentar a problemática da contínua e persistente tentativa de apropriação privada desse bem comum.

A água mineral engarrafada como bebida para consumo humano nos parece ser o exemplo mais notório da apropriação privada da natureza, da abordagem marxista de que tudo, até mesmo a natureza, sob o capitalismo é mercadoria. A água assim se torna objeto, em se encaixa, no sistema de objetos de que falava Milton Santos (1997):

"O espaço é hoje um sistema de objetos cada vez mais artificiais, povoados por sistemas de ações igualmente imbuídos de artificialidade, e cada vez mais tendentes a fins estranhos, ao lugar e a seus habitantes. Neste nosso mundo se estabelece, por isso mesmo, um novo sistema da natureza, uma natureza que, graças exatamente ao movimento 
ecológico, conhece o ápice de sua desnaturalização" (SANTOS, 1997, P. 90).

O mercado de água mineral engarrafada para o consumo humano é um dos objetos circunscritos nesta pesquisa porque é um dos mercados que mais crescem nos Estados Unidos, na China e em todas as partes prósperas atualmente da Ásia e também porque representa este paradoxo. A água é um bem natural, patrimônio comum da humanidade, que deveria, portanto, ficar fora da apropriação privada. Não é um objeto inventado pela mente humana, portanto deveria ser insuscetível de patenteamento ou de apropriação por marca. Nem mesmo o ato do engarrafamento (que é mero armazenamento) é uma criação humana recente e está longe, assim, de se constituir ato de propriedade intelectual.

O direito de patente decorre do gênio humano, é um direito que tem como fundamento o resultado do esforço de criação inventiva do homem que "soluciona um problema técnico; é o resultado de um ato criativo, surge algo então inexistente" (PIMENTEL, 1999, p. 23). A água não é invento, portanto não é um bem patenteável. Não se tem notícia no mundo de tentativa de patenteamento da água, embora se tenha tentado a do cupuaçu, outro bem natural. Não obstante as águas minerais serem exploradas comercialmente sob o título de marca e não de patente, o resultado acaba sendo semelhante na medida em que as empresas se apropriam da fonte, e, através da exploração da marca criam um monopólio sobre aquela fonte, quando esta deveria ser de uso comum, partilhado com todos.

David Harvey afirma que a despossessão, forma antiga de acumulação violenta, características das eras coloniais, continua sendo praticada hoje, de forma ilegal ou por meios legais, sendo que estas "incluem a privatização do que antes era considerado como recursos de propriedade comum (como a água e a educação), o uso do poder público para apreender bens, as práticas generalizadas de aquisições, as fusões e outros mecanismos similares..." (HARVEY, 2010, p. 48).

Para efeitos da pesquisa aqui desenvolvida, adotamos o conceito de água mineral usualmente adotado pelos institutos reguladores, como sendo a água carbonatada ou não carbonatada de fonte do solo.

Embora as fontes de água sejam diversas, com características de composição mineral diversas, situados nas mais diversas regiões do mundo, o mercado mundial de águas minerais é dominado por poucas empresas, que mantém seus rótulos e marcas 
regionais. São elas a Nestlé (com as marcas San Pellegrino, Nestlé Pure Life, Perrier, Vittel, Poland Spring, Contrex, Arrowhead, Acqua Panna e São Lourenço e mais outrass 46 marcas menos conhecidas ao redor do mundo $^{19}$ ), a Danone (com as marcas Aqua, Evian, Bonafont, Mizone, Villa Del Sur, Zywiec Zdroj, Fonte Vela, Volvic e Badoit) e a Coca-Cola (Bonaqua, Aqua bona, Apollinaris, Dasani, Aquarius Spring, Ades, Alhambra e dezenas de outras) ${ }^{20}$.

Imagem 1 - Marcas de água Nestlé

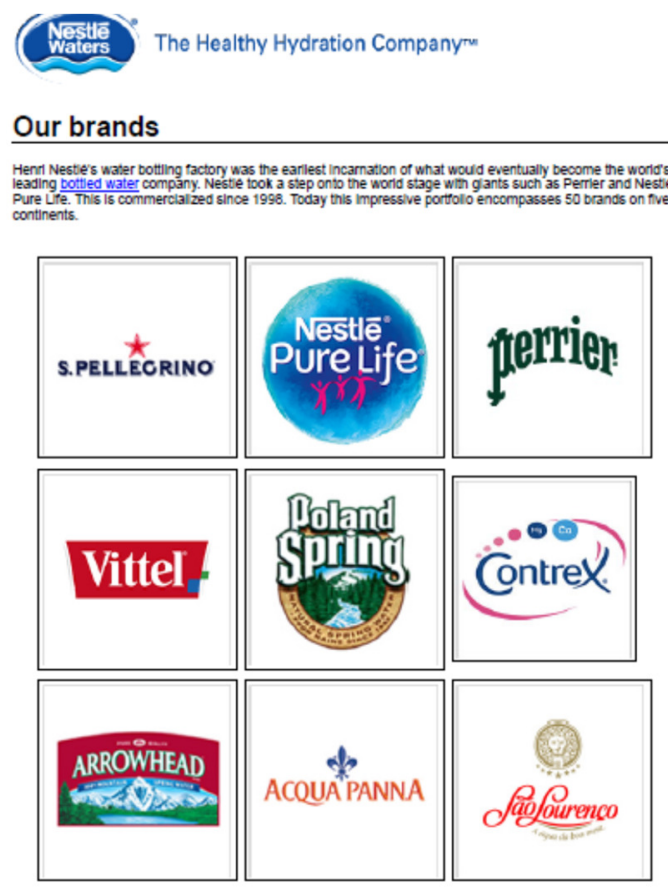

Fonte: Site da marca Nestlée ${ }^{21}$.
Imagem 2 - Marcas de água Danone
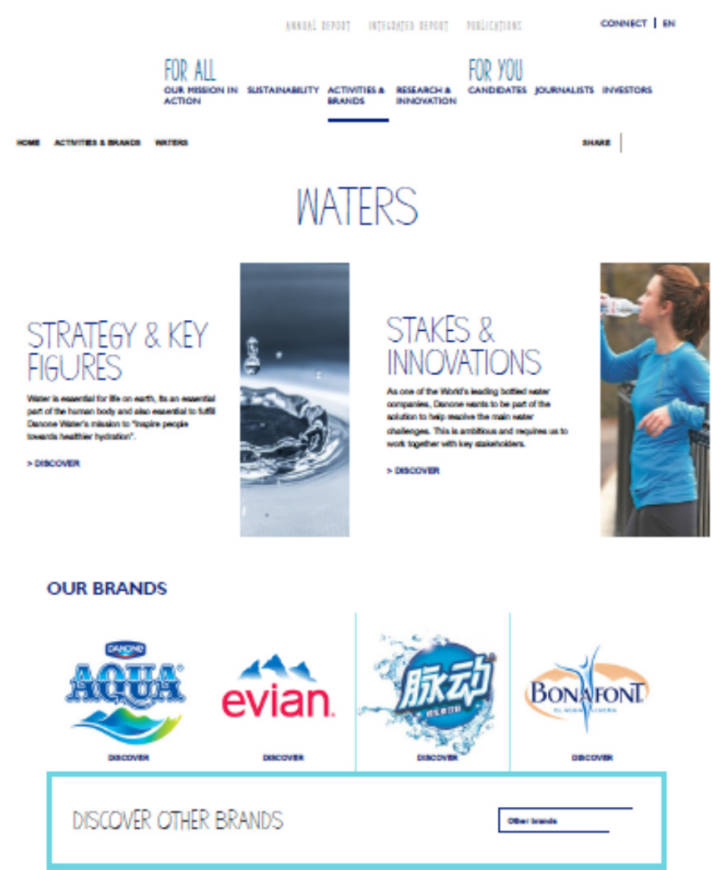

Fonte: Site da marca Danone ${ }^{22}$.

Não haveria problemas, à primeira vista, se a água fosse um bem de inesgotável renovação. Haveria para todos, e dentro de uma lógica capitalista em que tudo é mercadoria, inclusive a natureza, a água mineral engarrafada seria apenas mais um produto comercializável. A questão, porém, vai além. A água é um bem que rareia no mundo. Ainda que se entenda que os movimentos ambientais, às vezes, tenham um exagero em seus alarmes e denúncias, é inegável o avanço da contaminação da água em lençóis freáticos e da sua escassez em diversos pontos do planeta.

\footnotetext{
${ }^{19}$ No Brasil a Nestlé detém ainda as marcas Santa Bárbara e Petrópolis.

${ }^{20}$ No Brasil, a Coca-Cola explora a marca Cristal.

${ }^{21}$ Disponível em: https://www.nestle-waters.com/brands. Acesso em 23/02/2018.

${ }^{22}$ Disponível em: http://www.danone.com/en/for-all/our-4-business-lines/waters/. Acesso em 23/02/2018.
} 
Para Saskia Sassen (2016), a atual situação da água no mundo é grave:

"com a utilização do fraturamento hidráulico, as empresas de mineração estão se tornando algumas das maiores consumidoras de água no mundo desenvolvido, tanto direta quanto indiretamente pelo envenenamento de reservas hídricas. Com menos alarde, as empresas de refrigerantes e de água mineral também aumentam rapidamente seu consumo. Juntos, esses diversos atores esgotaram toda a reserva de água subterrânea disponível em várias partes do mundo. Para compensar a escassez da água, atualmente a Nestlé e outras empresas de engarrafamento constroem enormes tubulações, utilizam supertanques e gigantescas bolsas seladas para transportar o líquido por longas distâncias para fins comerciais" (SASSEN, 2016, p. 225).

\subsection{1 Água mineral nos Estados Unidos.}

Nos Estados Unidos, onde o saneamento básico e a oferta de água potável pela rede pública é uma conquista antiga, o consumo de água engarrafada tem crescido constantemente em uma clara adoção da lógica da apropriação das fontes de água pelas grandes empresas multinacionais. No ano de 2016 os Estados Unidos já tinham se tornando no $4^{\mathrm{a}}$ maior mercado consumidor per capita do mundo, atrás de México, Tailândia e Itália e o $2^{\circ}$ colocado na lista de consumo absoluto, atrás apenas da China. ${ }^{23}$

De acordo com a agência de proteção ambiental (Environmental Protection Agency - EPA), órgão público norte-americano, existem 151 mil sistemas públicos de fornecimento de água potável à população americana ${ }^{24}$, mas também é aberta à exploração pela iniciativa privada. O próprio site da agência estatal informa que a água da torneira é segura e que as águas engarrafadas podem ser úteis em caso de inundação ou terremoto. Enquanto que a água da torneira é regulada pela agência ambiental, a água engarrafada é regulada pela agência alimentar e de drogas (Food and Drug Administration FDA - Administração Alimentar e de Drogas).

Em observação das prateleiras dos supermercados no interior do país (fotos 1 a 4 abaixo) é possível constatar a oferta de águas engarrafadas das principais marcas mundiais, além de outras marcas locais.

\footnotetext{
${ }^{23}$ Fontes: www.worldatlas.com; www.statistas.com.

${ }^{24}$ Disponível em: https://www.epa.gov/dwreginfo/information-about-public-water-systems. Acesso em 03/06/18.
} 
Fotografia 2 - Marca Aquafina da empresa Pepsi Co- Fotografia 3 - Marca PureLife da Nestlé
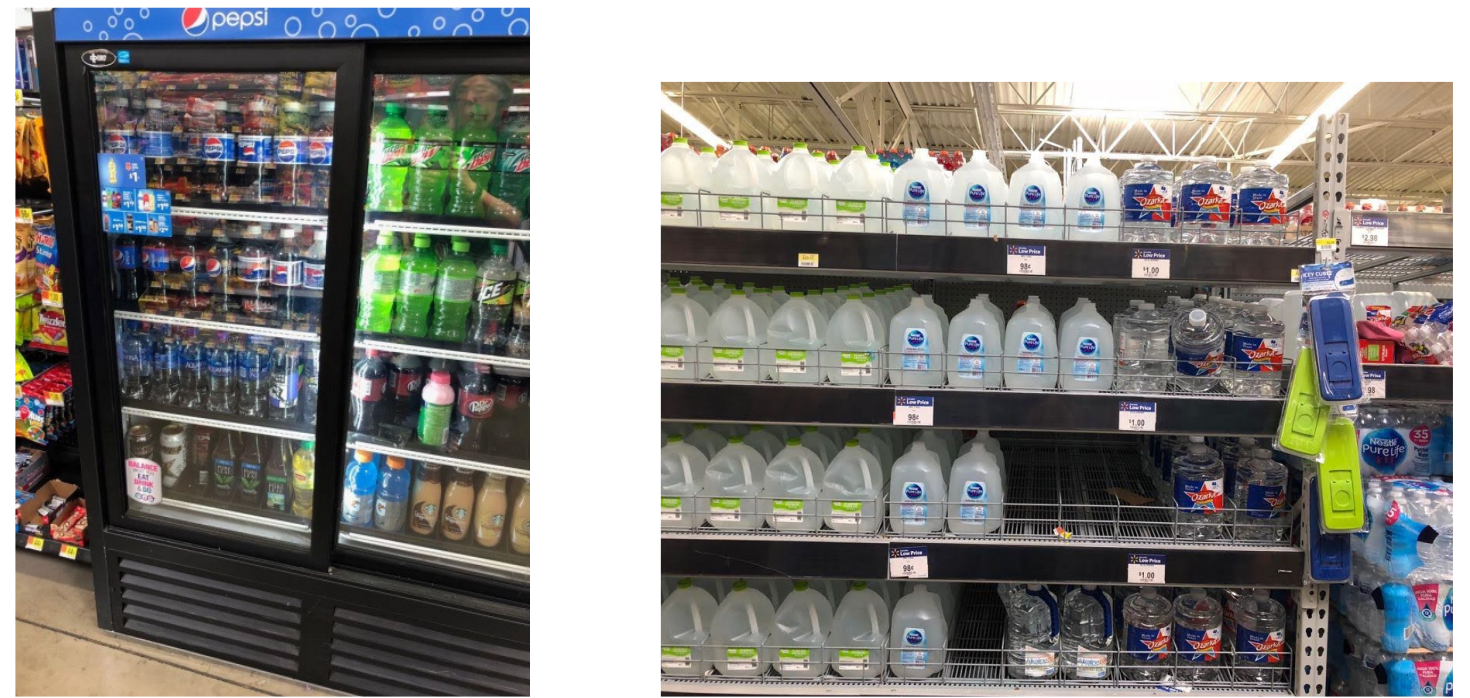

Fonte: Fotos 2/3 tiradas no supermercado Walmart na cidade de Rayton - Estado de Missouri, por Miryan K. Andaku em 25/05/18

Fotografias 4/5 - Marca Dasani da Coca-Cola
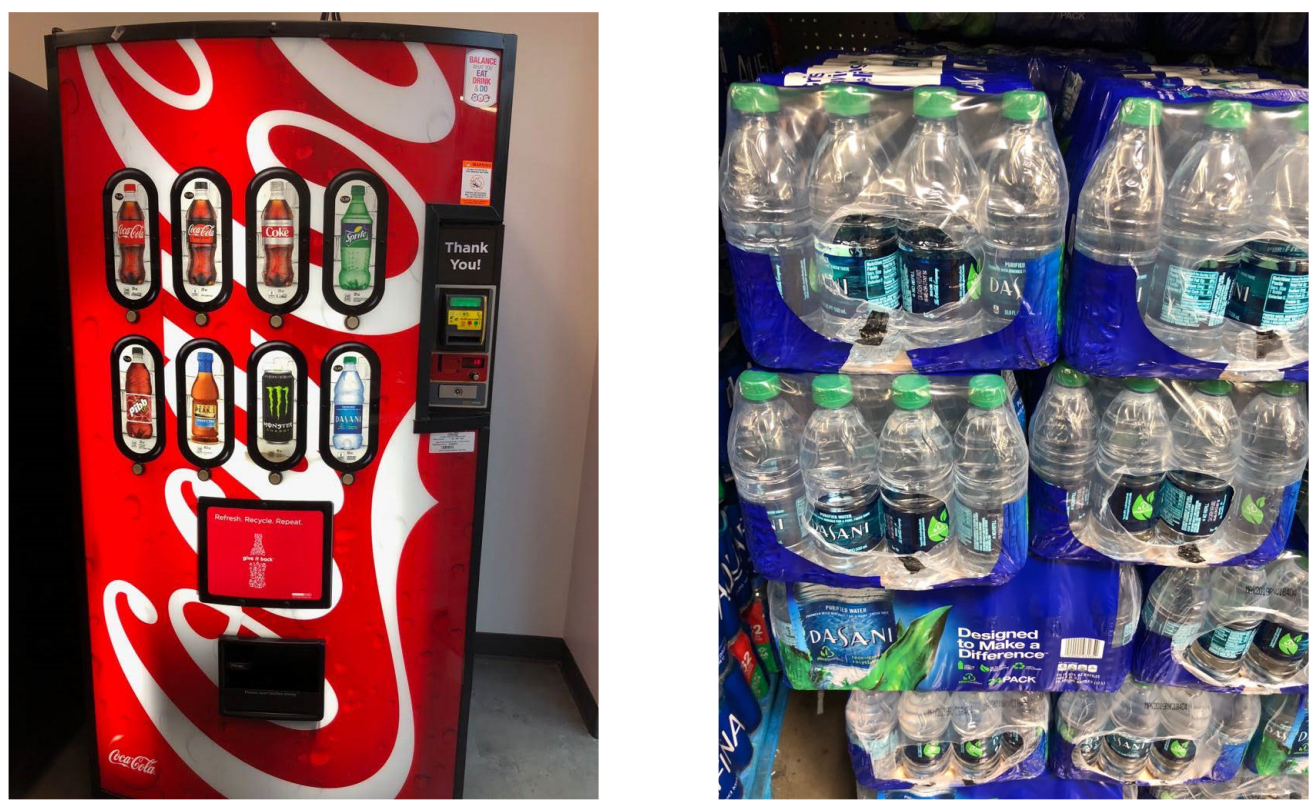

Fonte: Fotos tiradas no supermercado Walmart na cidade de Rayton - Estado de Missouri, por Miryan K. Andaku em 25/05/18 


\subsection{2 Água mineral na China.}

A China é um dos mercados que mais crescem no mundo, inclusive no consumo de água engarrafada para consumo humano, reproduzindo o modo de vida ocidental. O país é o maior consumidor em consumo absoluto de água mineral engarrafada. Embora a China detenha, em seu território 6,5\% da água potável do mundo, ela tem um quinto da população mundial. A indústria da água mineral alega que seu rápido crescimento industrial criou problemas ambientais, incluindo contaminação das águas e explora esse alegado fato para impulsionar a publicidade de seus produtos. De acordo com a consultoria para o mercado chinês Daxue Consulting, no início de 2013, 7.500 carcassas de porcos podres foram encontradas flutuando no Rio Huangpu. Para a consultoria, este panorama leva os chineses a consumirem água mineral engarrada ${ }^{25}$.

Em relatório de consultoria de marcas Kantar Worldpanel, no ano de 2017, as dez primeiras marcas preferidas dos chineses, no tocante aos bens de consumo em geral, eram marcas chinesas, algumas poucas conhecidas no Ocidente ${ }^{26}$. Porém as empresas estrangeiras, as transnacionais americanas e europeias estão presentes no mercado específico das águas minerais.

A empresa francesa "Danone", em parceria com a empresa local Hangzhou Wahaha tinha mais de $30 \%$ das vendas no ano de 2006. As empresas Nestlé, com suas marcas Vittel, Perrier, S. Pellegrino, Nestlé Pure Life e Nestlé Aquarel também é uma das líderes do mercado. A Coca-Cola está presente no mercado chinês de águas engarrafadas com as marcas Ice Dew e Sensation. A Coca-Cola, aliás, tentou a compra da empresa chinesa Huiyan Juice Group, mas a transação foi barrada pelo Ministério do Comércio com base na lei antimonopólio ${ }^{27}$.

\footnotetext{
${ }^{25} \mathrm{http}: / /$ daxueconsulting.com/bottled-water-market-in-china/

26 Disponível em: https://www.dci.com.br/opiniao/direto-da-china/mercado-interno-chines-sustentamarcas-domesticas-de-bens-de-consumo-1.663231/3.291475. Acesso em 23/02/18.

27 Disponível em: https://www.foodbev.com/news/the-chinese-bottled-water-market/. Acesso em $13 / 02 / 2017$.
} 
Fotografias 6/7 - água mineral da marca Aquarius - Coca-Cola, vendida em supermercado da rede Carrefour na cidade de Xangai na China.
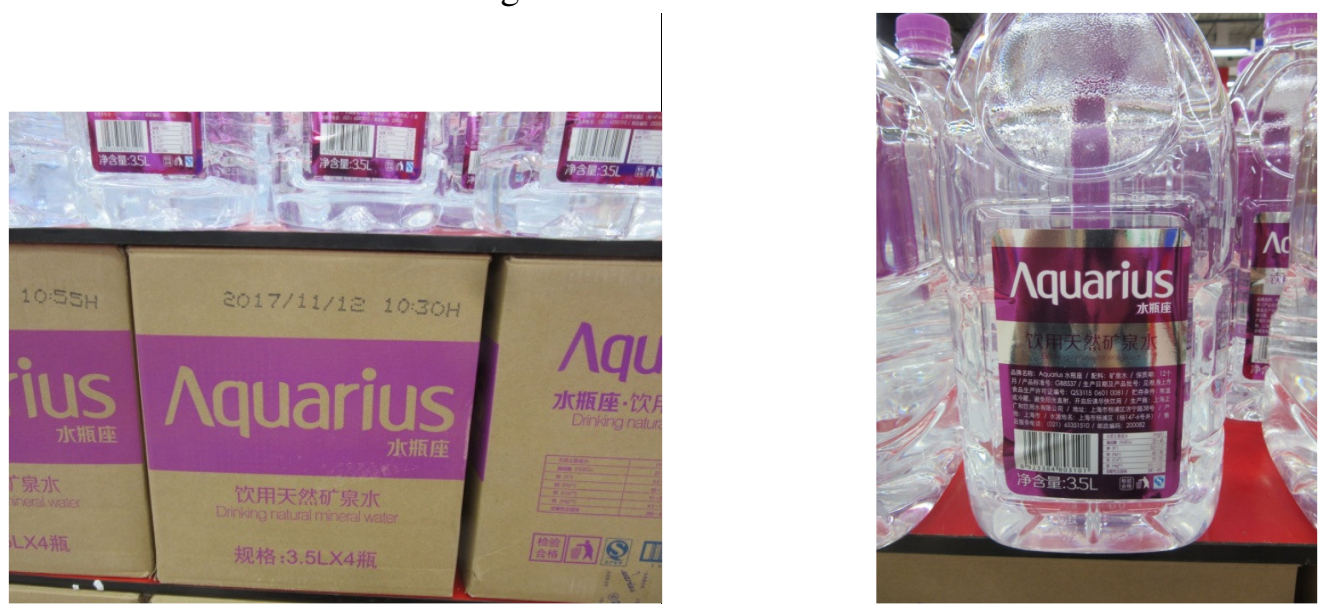

Fonte: Foto tirada em 17/11/17 por Juliana R.I. Andaku

Fotografias 8/9 - Água mineral "C'est bon" de empresa chinesa Hua Run, vendida em supermercado da rede Carrefour na cidade de Xangai
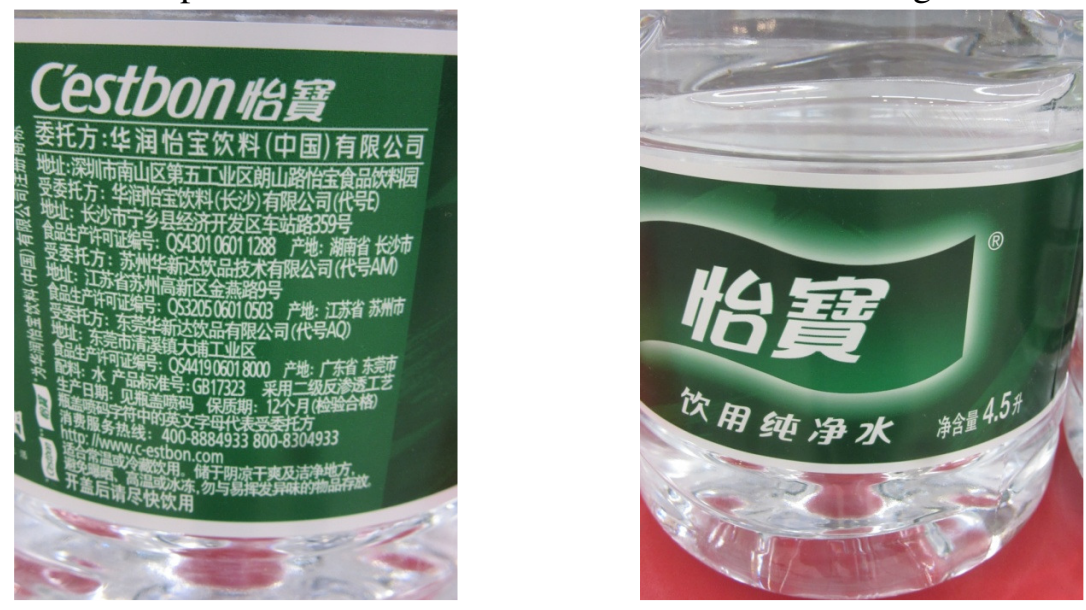

Fonte: Foto tirada em 17/11/17 por Juliana R.I. Andaku.

Em recente divulgação dos cinco homens mais ricos do mundo em 2020, aparece o nome de Zhong Shanshan, fundador da Nongfu Spring, empresa de água mineral, fundada por ele em 1996 e que detém um quinto do mercado de água engarrafada na China ${ }^{28}$. Nota-se, assim, a importância desse produto no mercado chinês e a adoção de hábitos ocidentais entre a população de poder aquisitivo na China.

\footnotetext{
${ }^{28}$ Disponível em: https://economia.uol.com.br/noticias/bbc/2020/12/24/quem-sao-os-cinco-bilionariosque-mais-aumentaram-suas-fortunas-em-2020.htm. Acesso em 25/12/2020.
} 
O mercado de águas minerais na China chegou a tal ponto que se pode comprar garrafas de $500 \mathrm{ml}$ pela internet, como as oferecidas pelo principal portal de vendas na China, a Alibaba, de água minerais do Lago Baikal, vendidas como as águas minerais mais puras do mundo (Imagem 3). A empresa russa Baikalika alega usar de tecnologia blockchain para garantir a qualidade da água e explora o mercado chinês como seu principal mercado desde 2015, e recentemente procurando expandir para outras localidades do Oriente Médio, Ásia e Europa.

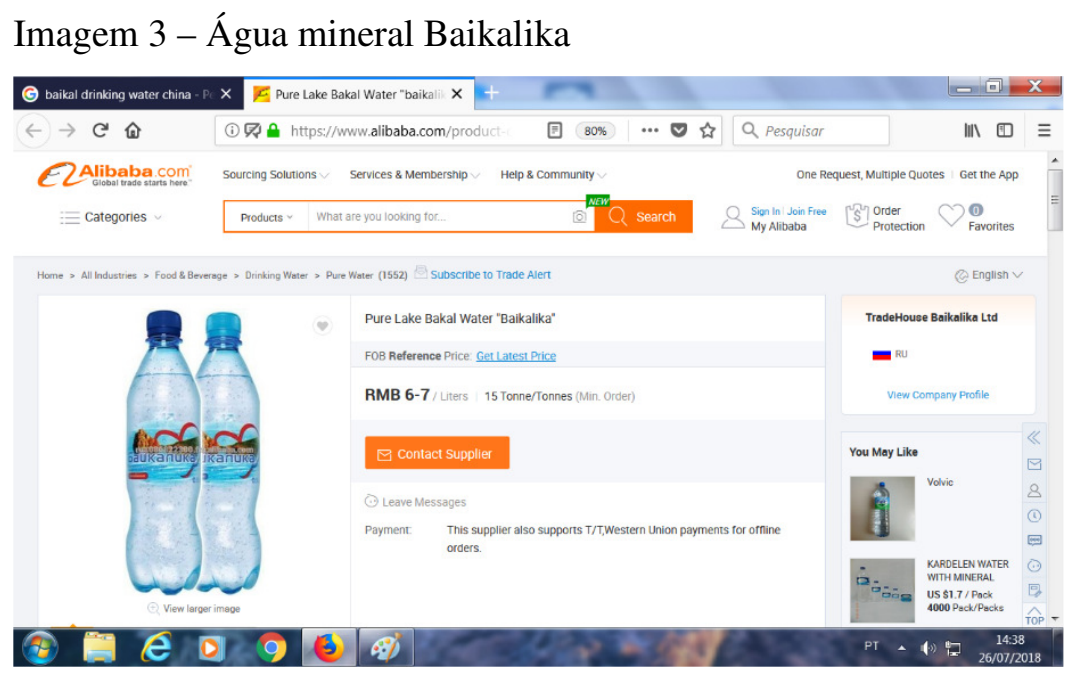

Fonte: Obtida pelo autor no site da empresa chinesa Alibaba

\subsection{3 Água mineral nos outros países}

As águas minerais engarrafadas com marcas das grandes empresas alimentícias mundiais estão presentes em todo o mundo, conforme demonstram os sites de estatísticas de consumo do setor. No caso do Brasil as prateleiras dos supermercados não deixam dúvida. Embora o consumo per capita no Brasil ainda seja baixo, o consumo absoluto coloca o Brasil no $5^{\circ}$ lugar, atrás de China, Estados Unidos, México e Indonésia. A Tailândia, Itália, Alemanha, França e a Índia, vêm em seguida na lista.

A tendência parece ser mundial e as mesmas transnacionais estão presentes no mundo todo, em clara demonstração de oligopólio. 
Fotografias 10/11 Máquina de bebidas em Seul, na Coréia do Sul
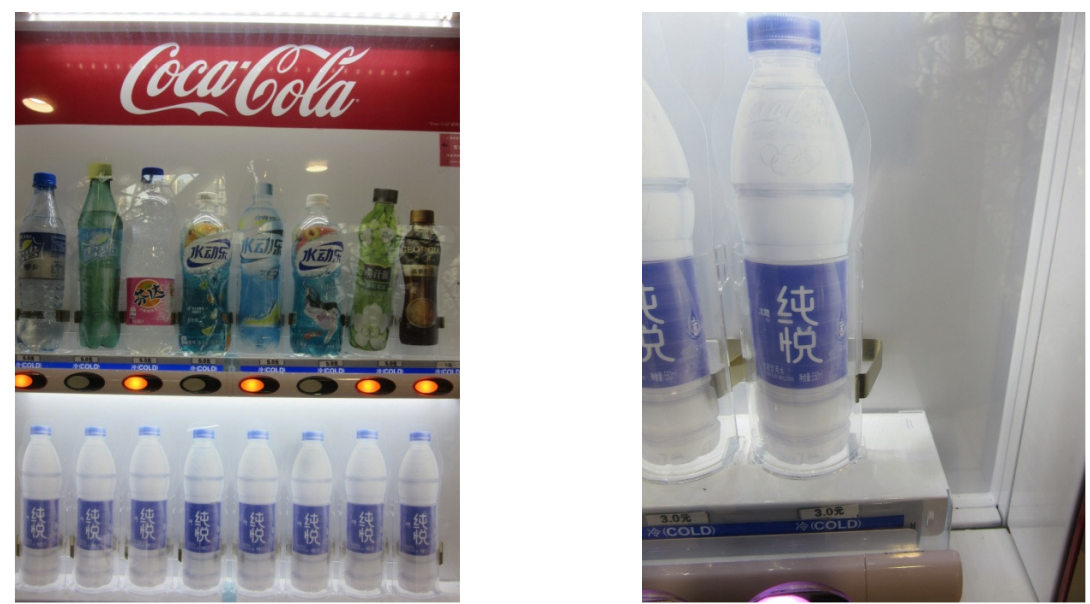

Fonte: Foto tirada em dez/17 por Juliana R. I. Andaku.

Fotografia 12 - Água da marca Crystal da empresa Coca-Cola - Foto13, Garrafas de água mineral de marcas da empresa Nestlé
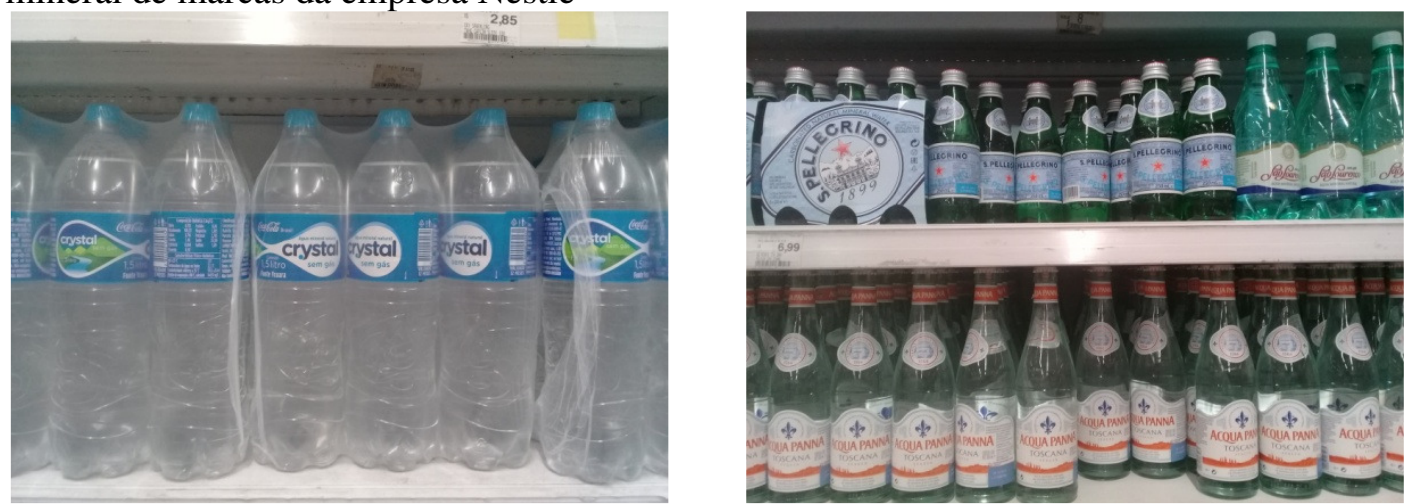

Fonte: Fotos do autor, tiradas em 16/02/16 no supermercado Extra da Av. Ricardo Jafet, São Paulo, SP. 
Fotografia 14 - Garrafa de água comprada em junho de 2016 na Cidade de Asunción, Paraguai da marca Dasani da empresa Coca-Cola/Paraguai Refrescos S/A.

Fotografia 15 - Garrafa de água comprada em Havana, Cuba, em abril de 2015 da marca Naturales da Empresa Ciego Montero CMex, concessão da Coca-Cola Mexicana.
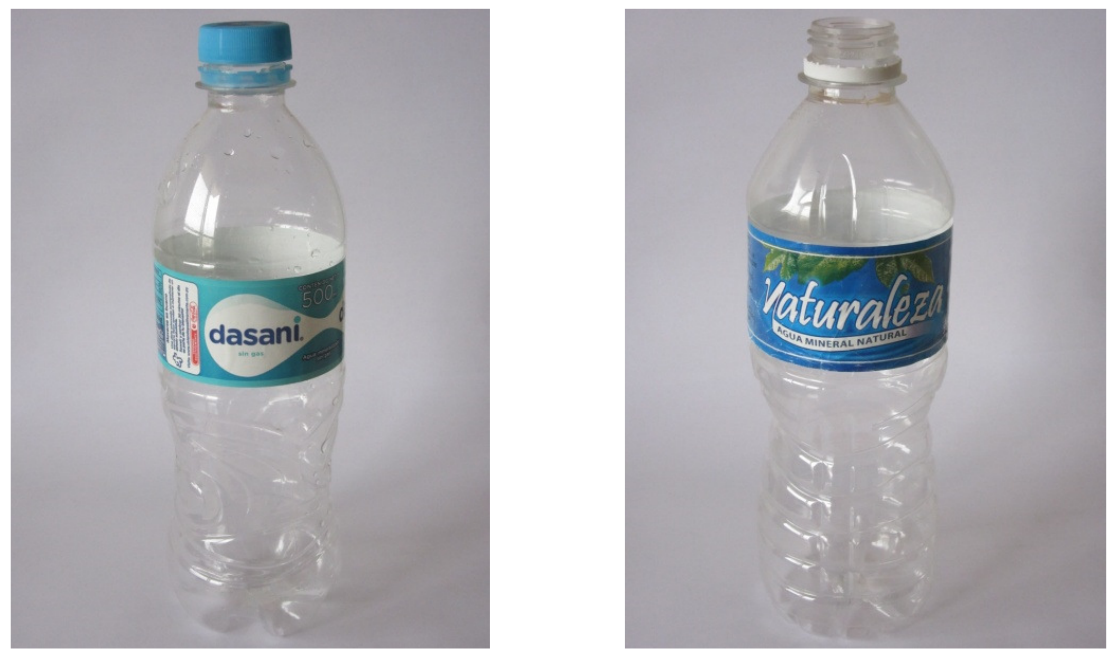

Fonte: fotografias do autor

Foto 16 - Água Mineral Dasani da empresa Coca-Cola e Evian da marca Danone em máquina de bebidas e alimentos do aeroporto de Toronto

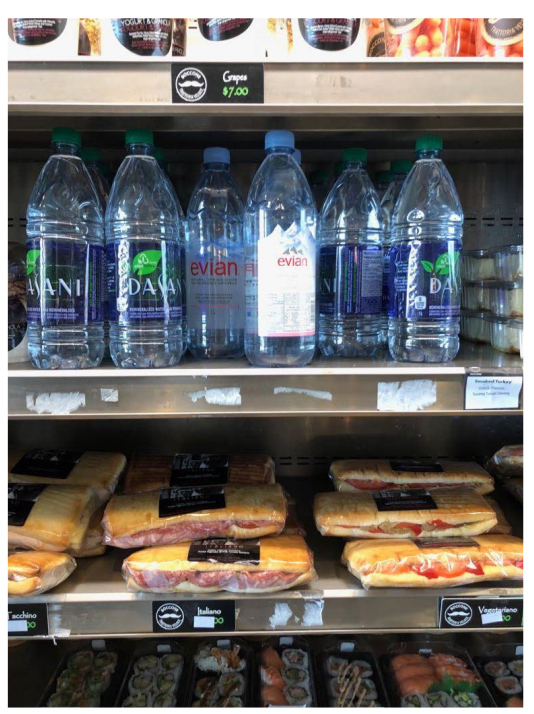

Fonte: Foto de Miryan K. Andaku - 22/05/18

Nota-se na pesquisa empírica, ainda que superficial, a presença maciça das três maiores transnacionais do setor em vários países do mundo, confirmando-se os números que encontramos na pesquisa dos sites de estatísticas mundiais, em concentração do consumo de poucas marcas. A presença da água mineral Dasani, da empresa Coca- 
Cola é marcante. A marca Coca-Cola, segundo a empresa de consultoria Interbrand fora avaliada há mais de dez anos em 79.623 bilhões de dólares ${ }^{29}$.

Uma característica interessante em todas elas é a ideia (e simbologia) da pureza, do alpino (mesmo para marcas de fora da Europa) com predominância das cores azul (água) e verde (matas) com brancos puros, e de nomes que remetem ao cristalino (cristal, naturaliza, aquarius, purê life, etc). E algumas, sem subterfúgios apresentam a própria descrição de suas características, como a marca Thonon da França (fotografia 17) como "água mineral natural dos Alpes” ou a Highland Spring, da Escócia (fotografia 18) como "água de fonte corrente, obtida de terras orgânicas".

Fotografia 17

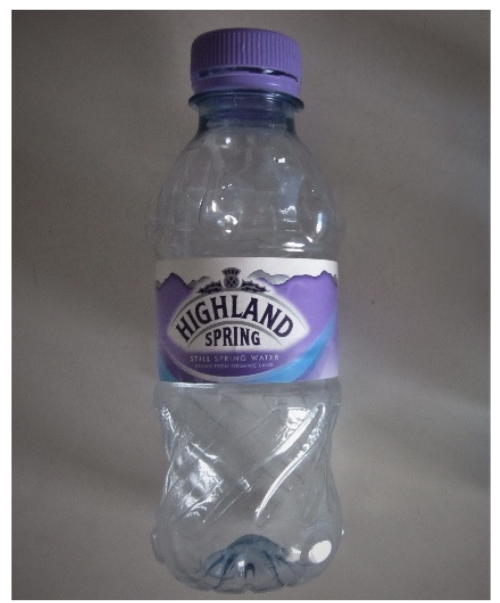

Fotografias do autor
Fotografia 18

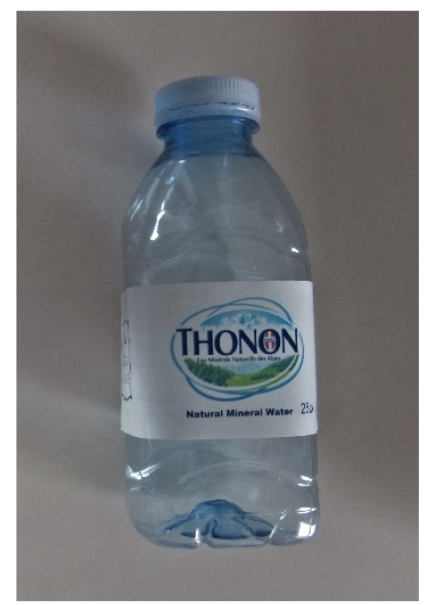

${ }^{29}$ Disponível em http://mundodasmarcas.blogspot.com.br/2006/05/coca-cola-always.html. Acesso em $12 / 06 / 2018$ 
II - Nem a mão nua nem o intelecto, deixados a si mesmos, logram muito. Todos os feitos se cumprem com instrumentos e recursos auxiliares, de que dependem, em igual medida, tanto o intelecto quanto as mãos. Assim como os instrumentos mecânicos regulam e ampliam o movimento das mãos, os da mente aguçam o intelecto e o precavêm.

III - Ciência e poder do homem coincidem, uma vez que, sendo a causa ignorada, frustra-se o efeito. Pois a natureza não se vence, se não quando se lhe obedece. E o que à contemplação apresenta-se como causa é regra na prática.

Francis Bacon Novum Organum ou Verdadeiras Indicações acerca da Interpretação da Natureza.

"Há muito o que dizer sobre a visão estreitamente utilitária da educação. Não temos tempo de aprender tudo antes de começar a ganhar a vida e não resta dúvida de que o conhecimento 'útil' é muito útil. Foi ele que construiu o mundo moderno. Sem ele não teríamos máquinas, automóveis, ferrovias nem aviões. Não teríamos também a propaganda moderna, deve-se acrescentar. O conhecimento moderno trouxe uma imensa melhoria nos níveis de saúde e descobriu-se, também, como exterminar toda a população das grandes cidades com gases venenosos. Tudo o que distingue o nosso mundo atual das épocas anteriores tem sua fonte no conhecimento 'útil'”.

Bertrand Russel em 1935 (2002, p 39-40) 


\section{SEGUNDA PARTE}

\section{AS PATENTES DE INVENÇÃO}

As citações que abrem este Capítulo a propósito da importância do conhecimento "útil" são feitas sem qualquer demérito dos outros conhecimentos e saberes, mesmo porque a citação de Russel é extraída de seu livro "O Elogio ao Ócio", uma compilação de artigos publicado pela primeira vez em 1935, em que defende que o trabalho não é o principal objetivo da vida e que o "ócio" pode ampliar o conhecimento e a capacidade de reflexão. Trazemos a citação apenas para reforçar a importância do conhecimento técnico no mundo moderno, nessa parte que trata de como o conhecimento técnico é protegido pelos direitos de propriedade intelectual. Francis Bacon, por outro lado, é tido como o primeiro filósofo da Ciência Moderna, formulador do método indutivo, o homem que "afirmou que 'conhecimento é poder', uma lição indubitavelmente amadurecida pela experiência. O tipo de conhecimento que Bacon tinha em mente é aquele que chamamos de científico" (RUSSEL, 2002, p. 36), nas palavras de Russel.

Adam Smith (1996, p. 67) já anunciava em seu “A riqueza das nações” que "As nações mais opulentas geralmente superam todos os seus vizinhos tanto na agricultura como nas manufaturas; geralmente, porém, distinguem-se mais pela superioridade na manufatura do que pela superioridade na agricultura".

Após uma ampla industrialização na Europa Ocidental, nos Estados Unidos e no Japão ao longo do século XX, e principalmente nos Estados Unidos, passou a se observar uma mudança ao final do século e início do Século XXI com o deslocamento da produção industrial mais tradicional (metalurgia, roupas, calçados, materiais plásticos) para outros países, subdesenvolvidos e principalmente para aqueles em desenvolvimento (que Arrighi [1997] chama de "eternamente em desenvolvimento" e assim em grupo "semiperiférico" ao centro do sistema capitalista), e levando assim a uma queda do percentual do setor manufatureiro no conjunto do produto interno bruto dos países centrais.

Esse processo de deslocamento da indústria manufatureira tradicional, acrescida de um aprofundamento do processo denominado de "globalização" muitos foram levados a acreditar que os serviços ganharam a relevância a ponto de se tornarem o setor mais importante da economia. Klein (2002), por exemplo, aponta a importância 
do serviço de construção de marcas, como novo destaque central da economia dos países desenvolvidos, usando em especial os exemplos de Estados Unidos e Canadá.

No entanto, nunca consumimos tantos produtos industrializados antes na história da humanidade, conforme afirmou Ha Joon Chang ${ }^{30}$ em Seminário Internacional na Pontifícia Universidade Católica (informação verbal). Para o autor a indústria e sua base manufatureira é o motor de toda a economia com seu sistema de produção e inovação.

Livesey (2017, p. 158), como veremos em seguida, analisa o percentual de empregos na indústria e a produção industrial de 1970 a 2012, em medição bianual, de Estados Unidos, França, Alemanha, Japão, Coréia do Sul e o Reino Unido para concluir que "A manufatura não acabou, ela mudou sua estrutura e sua posição em relação aos elementos de serviços da economia".

Também para Andreoni e Gregory (2013), a produção industrial continua sendo o motor do mundo e é possível constatar esse fato utilizando-se dos fundamentos tradicionais do pensamento econômico e da observação da nova realidade mundial. Deixando as análises de políticas macroeconômicas, que sozinhas não podem explicar a nova dinâmica, os autores afirmam que é preciso observar os subsetores industriais e os níveis de atividades de produção tendo em conta a nova realidade do sistema de produção global em redes. Com essa perspectiva é possível entender porque algumas indústrias são mais importantes que outras e porque a relação decorrente da tecnologia da indústria manufatureira é central na capacitação do país para gerar inovação tecnológica.

Em outras palavras, retomando um enunciado de Ha Joon Chang (2018), "Para inovar é preciso estar produzindo". Observamos que uma grande parte da produção industrial foi transferida para os países pobres ou em desenvolvimento, onde a mão de obra é mais barata, há matéria prima abundante e a preservação do meio ambiente pode ser ignorado em vista da fragilidade das instituições governamentais. Mas os países centrais retomam cada vez mais a produção industrial daqueles setores que são importantes para a inovação tecnológica.

Tomando a Suíça como exemplo, que é comumente vista como país que enriquece com seu amplo leque de serviços como os financeiros, depósitos bancários e de turismo, a produção industrial é ainda de capital importância para o país. Os dados da Organização Mundial do Comércio demonstram que a indústria ainda é responsável pela

30 Informação fornecida por Ha Joon Chang em 09 de janeiro de 2018 no Seminário de Economia Internacional promovido pela Pontifícia Universidade Católica de São Paulo. 
maior parte de seu comércio exportador e o índice de industrialização do país é dos mais altos (Figura 1).

Figura 1: Desempenho industrial de Estados Unidos, China, Suíça e Brasil ${ }^{31}$. $\therefore$ TCdata360 Industrialization Intensity Index, Value

\section{\begin{tabular}{l|l|l|l|l}
$x$ Brazil & $\times$ China & $x$ Switzerland & $x$ United States
\end{tabular}}

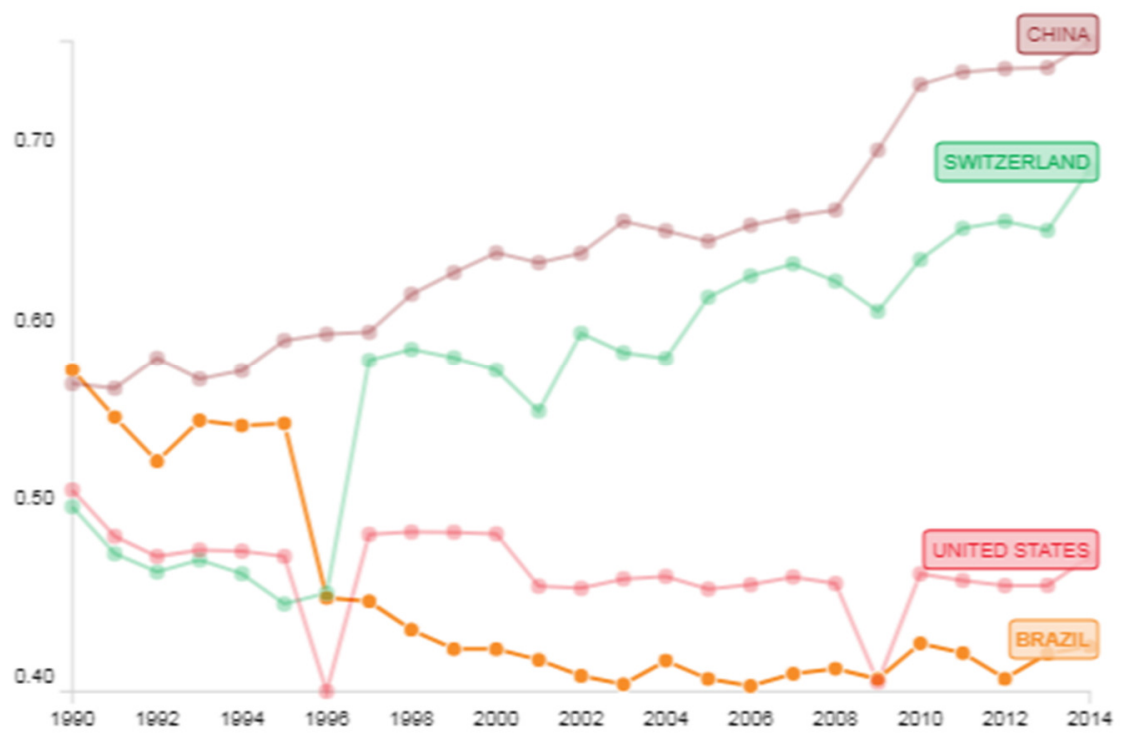

- For Regional and Income Group breakdowns, visit Knowledgebase Article $=378834$. For information on the Suggested Peers algorithm, visit the Tools page.

Data Source: UNIDO-Competitive Industrial Performance Index $\checkmark$

\section{WORLD BANK GROUP}

https://tcdata360.worldbank.org/indicators/mva.ind.i

Fonte: Gráfico elaborado pelo autor a partir do próprio site do Banco Mundial.

Sem dados atuais para o que o Banco Mundial denominava de índice de intensidade da industrialização, atualizamos para o ano de 2019 os percentuais de trabalhadores na indústria, que segue o mesmo padrão e observamos o mesmo quadro,

\footnotetext{
${ }^{31} \mathrm{O}$ índice tem como variáveis a capacidade produtiva, a intensidade de industrialização e o impacto no mercado mundial dos componentes industriais produzidos.
} 
praticamente sem alterações em que a China tem $28,183 \%$ dos trabalhadores empregada na indústria em 2020 (praticamente mesmo patamar desde 2017, quando teve uma queda a partir do ápice atingido em 2012 quando tinha 30,3\% dos trabalhadores na indústria). A Suíça teve sensível queda de 21,608\% em 2012 para 19,97\% para 2020, enquanto os Estados Unidos, tiveram aumento de 19,744\% em 2012 para 19,807 em 2020. Aliás os Estados Unidos tiveram queda de empregos na indústria nos anos 1990, pois tinha $26,023 \%$ dos trabalhadores na indústria em 1991, caiu para 22, 263\% em 2003 e 19,609\% em 2010, e desde então apresentando estabilidade e pequena retomada dos empregos industriais. Desde 1991 o Brasil apresenta queda de empregos no setor industrial, quando tinha $23,291 \%$, caindo para 21,49\% em 2003, com alta para 2008 para 23,237\% e caindo constantemente desde então, apresentando em 2020 um índice de 19,951\% do pessoal trabalhador na indústria ${ }^{32}$.

Livesey (2017) demonstra que apesar dos empregos no setor industrial estarem caindo de maneira geral, a produção de bens tem aumentado. Esse fato da queda da empregabilidade do setor industrial:

"ignora o fato de que a maior parte dos países produzem mais agora do que no início dos anos 1990. A produtividade (a quantidade produzida por hora por trabalhador) tem aumentado, ou seja, com menos trabalhadores as fabricas são capazes de produzir mais e mais. Como a figura 3 ressalta, a Coréia do Sul tem aumentado sua produção de forma constante desde 1990, enquanto países como o Reino Unido, barrando a queda depois da crise financeira, tem mantido os níveis de produção mesmo com a queda dos empregos industriais (LIVESEY, 2017, p. 258, tradução do autor).

\footnotetext{
32 Dados obtidos no site do Banco Mundial. Disponível em: https://data.worldbank.org/indicator/SL.IND.EMPL.ZS?end=2020\&locations=US-CN-CHBR\&start=1991\&view=chart. Acesso em 20/12/2020.
} 
Figura 2 - Desempenho Industrial de Reino Unido e Coréia do Sul.

\section{$\therefore$ TCdata 360}

\section{Industrialization Intensity Index, Value}

\section{$\times$ Korea, Rep. $\times$ United Kingdom}

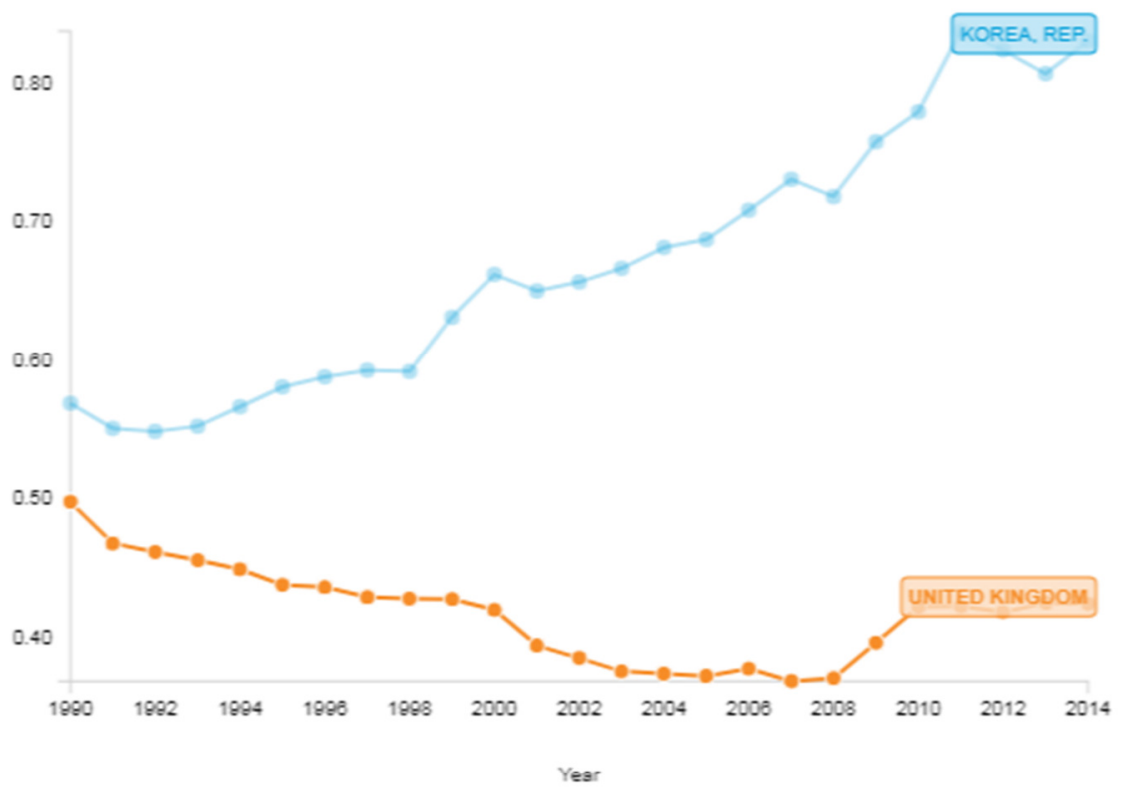

- For Regional and Income Group breakdowns, viait Knowledgebase Article $=378834$. For information on the Suggested Peers algorithm, viait the Tools page.

Data Source: $\quad$ UNIDO-Competitive Industrial Performance Index 6

\section{W1 WORLD BANK GROUP https://tcdata360.worldbank.org/indicators/mva.ind.i}

Fonte: Gráfico elaborado pelo autor a partir do próprio site do Banco Mundial.

Ao fazer a crítica do economicismo como corrente teórica construída a partir da transformação estrutural que transformou o homem e a sociedade em economia de mercado, Karl Polaniy (2012, p. 54) após afirmar que o passo crucial fora a transformação do homem e da terra em mercadorias, assevera que: "No que concerne ao homem, fomos levados a aceitar a ideia de que suas motivações podem ser descritas como 'materiais' ou 'ideais', mas os incentivos sobre os quais se organiza a vida cotidiana brotam necessariamente das motivações materiais". 
A crítica de Polaniy (2012) de que os incentivos da organização da vida cotidiana têm motivações materiais se mostra procedente na medida em que o consumismo atingiu faixas maiores da população mundial incorporando hábitos de consumo em todas as classes sociais, que tem sido a base do crescimento econômico no mundo todo, aprofundados nas últimas décadas, em que predominou o pensamento neoliberal como vimos nas questões a importância das marcas e sua repercussão simbólica dos objetos/mercadorias (BAUDRILLARD, 1993).

Importante assinalar, que a produção industrial atingiu tão elevado grau em nossa sociedade do consumo que ela subordinou a ciência. Se é verdade que a ciência já vinha sendo usada para inovações há muito tempo, pelo menos desde a chamada segunda revolução industrial, no final do século XIX (Braverman, 1987), também nos parece verdade que ela foi colocada em um papel de submissão ainda maior. Como afirma Milton Santos (1998, p. 6): “Ora, tudo isso só foi possível porque o trabalho científico foi praticamente colocado a serviço da produção. A ciência tem, doravante um papel produtivo (J. Thibault, 1967)".

Se para Livesey (2017), Chang (2002; 2018) e Andreoni e Gregory (2013) a produção industrial é de fundamental importância para o desenvolvimento econômico e os países centrais continuam a produzir e a gerar inovação, para o clássico John Kenneth Galbraith a inovação tecnológica é central na dinâmica do capitalismo. Falando do capitalismo industrial que emergiu no final do século XVIII, destaca que "o sistema econômico que surgiu subsequentemente foi, em grande parte, o fruto da tecnologia (1994, p. 1). E após analisar o deslocamento desse sistema (capitalismo industrial) para os estados alemães, a França, a outras partes da Europa, atravessar o Atlântico para os Estados Unidos e chegar à Ásia, afirmando que "tinha o dinamismo situacional que sobrevive até hoje", Galbraith destaca que "O deslocamento das indústrias básicas ou tradicionais dos países mais velhos para os novos por certo não deixa aqueles economicamente carentes; outras atividades econômicas sobrevivem e florescem. Existe a vantagem permanente da alta tecnologia inovadora (1994, p 4)."

Nesse deslocamento do processo industrializador para os Estados Unidos, pertinente é a lembrança da forma de chegada das novas tecnologias, por exemplo, pelo imigrante Samuel Slater, conforme relatada por Leo Huberman (1987) em seu "História da Riqueza dos Estados Unidos”. Após relatar que a Inglaterra passou a fiscalizar os emigrantes para impedir a saída de máquinas, peças e projetos de máquinas, conta a história de Slater: 
"Em 1789 veio para os Estados Unidos, secretamente, Samuel Slater, que havia sido operário nas fábricas inglesas. Levava consigo planos de máquinas novas - na cabeça. Em Pawtucket, Rhode Island, ele montou o primeiro conjunto completo para fiar linha, segundo o plano Arkwright; as máquinas ele as construía e desenhava de memória. $\underline{\mathrm{A}}$ Revolução tinha sido trazida para a América (HUBERMAN, 1987, p. 127. Grifos nossos).

Neste contexto passamos a observar o papel das patentes de invenção no desenvolvimento tecnológico, é que é um dos focos da presente tese, como central no desenvolvimento e ainda como instrumento metodológico na medida em que se tratam de poderosos indicadores da inovação. Quando analisamos os principais patenteadores dos países, sobretudo aqueles em estágio de desenvolvimento, observamos a presença de inúmeras instituições acadêmicas entre elas. No caso do Brasil, por exemplo, a Universidade Estadual de Campinas $\left(1^{\circ}\right)$, a Universidade Federal de Minas Gerais $\left(4^{\mathrm{a}}\right)$ e a Universidade Estadual Paulista Julio de Mesquita Neto ( $8^{\circ}$ ) figuraram, no ano de 2018, como os principais detentores de patentes registrados junto ao Instituto Nacional da Propriedade Industrial, sendo que $28 \%$ dos registros se originaram de Instituições de ensino e Pesquisa e órgãos do Governo ${ }^{33}$.

Interessante notar que também nos Estados Unidos, entre os dez maiores patenteadores, a Universidade da Califórnia tem sido uma presença constante, sempre com um índice de aproximadamente cinco centenas de patentes obtidas a cada ano ${ }^{34}$.

Importante destacar que a indústria hoje não é mais apenas a indústria manufatureira tradicional, embora ela seja também importante, mas uma indústria de uma tecnologia que eleva o impacto nas pessoas e, em consequência, nos territórios, de uma forma revolucionária. Se o automóvel tem levado cem anos de constante aperfeiçoamento, agora se faz o automóvel que dispensa o condutor. Se os computadores passaram por constantes aprimoramentos e de grandes máquinas nos anos 1950 diminuíram para o tamanho para se tornarem objetos pessoais em uma escrivaninha nos anos 1980. Hoje ele está no relógio ou no aparelho telefônico celular.

\footnotetext{
${ }^{33}$ Disponível em: https://www.gov.br/inpi/pt-br/composicao/estatisticas/RelatoriodeAtividades2018.pdf. Acesso em 02/10/20.

34482 patentes em 2017, 501 patentes em 2018 e 470 patentes em 2019. Disponível em: https://www.wipo.int/ipstats/en/statistics/country_profile/profile.jsp?code=US. Acesso em 02/10/10. Interessante para termos comparativos, a Universidade de Campinas apresentou nos mesmos anos, respectivamente 24, 30 e 9 patentes, sendo notória a queda no ano de 2019. Disponível em: https://www.wipo.int/ipstats/en/statistics/country_profile/profile.jsp?code=BR. Acesso em 02/10/10.
} 
O jornalista Tom Wolfe (2001, p. 38-46) procurou retratar o ambiente da nascente indústria eletrônica no Vale do Silício, com destaque para seus personagens principais nos primórdios dos anos de 1950. Relata como um grupo de engenheiros, formados nas melhores universidades do leste americano dentre os quais um ganhador do Prêmio Nobel de Física de 1956, William Shockley, que o ganhou pela invenção do transistor, foram se mudando para a Califórnia e fundando empresas e inovando em suas pesquisas. Em uma época em que já existiam grandes empresas como General Electric, IBM e Hewlett-Packard, Texas Instruments e Motorola, e a própria empresa de Shockley foi ficando para trás, pela saída de um grupo de engenheiros que constituíram uma nova empresa, um dos mais notáveis avanços foi a conjugação de duas invenções que determinaria o desenvolvimento dos aparelhos que nos cercam hoje:

\begin{abstract}
A fundação da empresa não podia ter ocorrido em melhor época. Por volta de 1957 já havia demanda suficiente - por parte de fabricantes que simplesmente queriam transistores em vez de válvulas para utilização em rádios e outros aparelhos - que justificasse o novo empreendimento. Mas foi também em 1957 que a União Soviética lançou o Sputinik I. $\mathrm{Na}$ indústria eletrônica, a corrida espacial que se seguiu teve o efeito de conjugar duas invenções novas - o transistor e o computador - e de amplificar a importância de ambas" (Wolfe, 2001, p. 43).
\end{abstract}

Em seguida o autor afirma que o primeiro computador eletrônico, desenvolvido pelo Exército americano tinha mais de trinta metros de comprimento e três de altura, com 18 mil válvulas eletrônicas. Os transistores substituíram as válvulas. Os transistores precisavam ser ligados por fios, o que era um problema, dada a extensão e quantidade dessa fiação. Dois engenheiros em locais diferentes, Bob Noyce, que havia deixado a empresa de Shockley, na California e Jack Kilby, no Texas, funcionário da Texas Instruments em Dallas, tiveram a ideia de fazer a ligação em uma placa de silício, que por sua condutividade possibilitava dispensar os fios. $\mathrm{O}$ circuito integrado ou o "microchip" estava criado e que estabeleceu todo o desenvolvimento nos aparelhos que usamos hoje, em tamanhos diminutos. "A importância do circuito integrado certamente não passou despercebida a John Carter e à Fairchild Camera em Nova York. Em 1959, eles exerceram sua opção de comprar a Fairchild Semiconductor por três milhões de dólares" (WOLFE, 2001, p. 46).

A importância dos circuitos integrados para o desenvolvimento tecnológico é inegável se olharmos sob o prisma do Direito. O que se denomina de "topografia" dos circuitos integrados é uma das mais protegidas propriedades intelectuais 
internacionalmente pelo citado Acordo Trips. Têm um regime jurídico de proteção que é chamado de sui generis, porque pode ser protegida na forma de direito autoral, patente, modelo de utilidade, desenho industrial, concorrência desleal ou a combinação das mesmas. Como invenções que se constituem em "um passo inventivo além do estado da técnica que facilita o trabalho humano e tem aplicação industrial"35, as topografias de circuitos integrados poderiam ser protegidas pela categoria mais geral de patentes de invenção.

Vemos, portanto, hoje que a indústria desde aquelas manufatureiras até as de alta tecnologia de microchips e biotecnologia se constituem em efetiva base material para atender às crescentes demandas do consumo mundial, devendo ser revistos os argumentos da existência de uma sociedade pós-industrial surgida com a diminuição de trabalhadores empregados na indústria e aumento no setor de serviços.

Há uma ideia sobre uma eventual imaterialidade do mundo atual permitido pelos avanços tecnológicos com conexões virtuais, armazenamento de dados em nuvem, inteligência artificial e processos digitais. Fala-se em um mundo virtual paralelo ao mundo real. Para Carolina Batista Israel (2019) em resposta a essas teorias, do mundo paralelo, em que este redefiniria os contornos do espaço material, representando a força do intangível sobre o tangível, "aflora a perspectiva teórica que aponta para a indissociabilidade entre as dimensões material e imaterial, ressaltando o caráter de dependência dos ambientes virtuais em relação à infraestrutura que os comporta. Aqui, a dimensão intangível do ciberespaço é condição imanente ao universo tangível" (ISRAEL, 2019, p. 18).

Asseverando que a relação se dá de maneira intrínseca e não paralela, Israel (2019) afirma que:
"As condições técnicas que permitiram o desenvolvimento da computação em rede estimularam, de forma igual e correspondente, $o$ desenvolvimento de qualidades virtuais que passaram a integrar a própria natureza do espaço geográfico no período técnico no qual encontramos, uma época na qual 'a ciência e a tecnologia, junto com a informação, estão na própria base da produção, da utilização e do funcionamento do espaço e tendem a constituir o seu substrato'(SANTOS, 2009 [1996], p. 160)." (ISRAEL, 2019, p. 19).

\footnotetext{
${ }^{35}$ Uma definição breve de patente.
} 
Ou seja, para que existam as redes digitais, de modo virtual, há toda uma infraestrutura física, material, constituída de cabeamentos de fibra ótica, fios, torres de transmissão, antenas, computadores em rede, que não apenas dá suporte ao virtual, mas coexiste concomitante e paralelamente, não se podendo falar em mundo virtual como se pairasse acima da realidade física e geográfica do mundo. Toda uma série de fixos geográficos precisam ser constituídos para a existência do virtual. 


\section{Capítulo 6}

\section{As patentes como instrumentos de desenvolvimento tecnológico, econômico e militar}

A importância do conhecimento em geral e do conhecimento tecnológico em especial para o desenvolvimento de uma sociedade nos planos econômicos, políticos, sociais e culturais é notória. Quando se fala em país ou sociedade rica, desenvolvida ou central se está, sobretudo, se referindo a países que atingiram um elevado grau de desenvolvimento tecnológico. Estamos a nos referir, portanto, ao objeto de fundo da presente tese: A afirmativa de que os países detentores da maior quantidade de marcas e patentes se constituem nos países que comandam a economia mundial e configuram o espaço mundial. A importância desse tema para a compreensão da Geografia é, assim, a nosso ver, fundamental para a compreensão do mundo contemporâneo.

É imperativo destacar inicialmente uma definição jurídica da patente. Denis Borges Barbosa (2003) define a patente como:

"um direito conferido pelo Estado, que dá ao seu titular a exclusividade da exploração de uma tecnologia. Como contrapartida pelo acesso do público ao conhecimento dos pontos essenciais do invento, a lei dá ao titular da patente um direito limitado no tempo, no pressuposto de que é socialmente mais produtiva em tais condições a troca da exclusividade de fato (a do segredo da tecnologia) pela exclusividade temporária de direito" (BARBOSA, 2003, p. 335).

O direito de explorar de maneira exclusiva o invento (possibilitada a cessão ou licenciamento a terceiros mediante o pagamento dos chamados "royalties") é conferido, por convenção internacional, pelo prazo de vinte anos. Essa exclusividade significa, obviamente, um monopólio deste invento, um monopólio sobre o passo inventivo que criou uma facilidade industrial.

Deste monopólio se está se falando, em consequência, do seu aspecto econômico. O direito de exclusividade decorre do aperfeiçoamento significativo do fazer manufatureiro. Uma situação de fato que nos remete aos primórdios da Revolução Industrial. Adam Smith apontou a importância deste aprimoramento ao estudar "As Riquezas das Nações" e formulou sua teoria sobre a divisão social do trabalho.

Para Smith (1996, p. 67-68) a divisão do trabalho na manufatura de um produto por partes dividido para diversos trabalhadores, cada um realizando uma operação específica, levou ao aprimoramento das forças produtivas. Ele cita o exemplo do alfinete, em que um trabalhador apenas desenrola o arame, "um outro o endireita, um 
terceiro corta, um quarto faz as pontas, um quinto afia nas pontas...". Uma atividade dividida enfim em "aproximadamente 18 operações distintas", possibilitando uma grande produção. A superioridade na manufatura distinguiria mais a nação opulenta do que a superioridade na agricultura, segundo Adam Smith, pelo grande aumento na quantidade de trabalho, decorrente da divisão, e "devido a três circunstâncias distintas: em primeiro lugar, devido à maior destreza existente em cada trabalhador; em segundo, à poupança daquele tempo que geralmente, seria costume perder ao passar de um tipo de trabalho para outro; finalmente, à invenção de um grande número de máquinas que facilitam e abreviam o trabalho, possibilitando uma única pessoa fazer o trabalho que, de outra forma, teria que ser feito por muitas.

Observamos que a invenção que facilita o trabalho, que dá a solução para o aumento da produtividade, ou seja, a invenção patenteável está no cerne das três circunstâncias apontadas por Adam Smith: aumenta a destreza do trabalhador, poupa tempo e facilita o trabalho.

Neste tema, o economista Joseph Schumpeter foi dos primeiros a reconhecer a importância da inovação para as economias capitalistas modernas. Segundo Menell (2003), “o trabalho de Schumpeter dá ênfase em três princípios: (1) as inovações perturbam continuamente as relações de mercado e de estruturas organizacionais através de um processo de 'destruição criativa; (2) a inovação tecnológica fornece a oportunidade para ganhos monopolísticos temporários, e esta ligação explica o rápido crescimento econômico das economias Ocidentais e (3) grandes empresas monopolísticas são a fonte primária de inovação tecnológica porque estão melhor capacitadas de suportar os altos custos da inovação" (MENELL, 2003, p.135).

Menell (2003, p.135) sustenta que os dois primeiros princípios são comumente aceitos pelos economistas que estudam a inovação, mas que o terceiro princípio não se verificaria, segundo esses economistas, na realidade empírica. Esses estudos apontariam que "as invenções são altamente interdependentes, que a tecnologia avançaria com uma gradual evolução que é intimamente ligada com o curso de suas difusões".

Esta posição é muito parecida com a do advogado americano Tim Wu (2012), para quem não existe um gênio inventivo na humanidade, mas um estado de técnica que permite a várias pessoas fazerem avançar as técnicas simultaneamente. Dando exemplos como a do telefone, sobre o qual descreve o desenvolvimento longo por mais de uma 
pessoa além de Graham Bell, e que teria sido inventado por mais de uma pessoa em um espaço de tempo muito próximo, afirma que:

"Justiça seja feita, o telefone não foi criado por uma pessoa só. Assim, o que chamamos de invenção, embora não seja fácil, simplesmente acontece quando o desenvolvimento tecnológico chega a um ponto no qual o passo seguinte se torna acessível para muitos" (WU, 2012, p. 26).

Menell (2003, p. 136) prossegue no mesmo tema afirmando:

\begin{abstract}
"Saxenian (1994) descreve como o processo de difusão depende não apenas de considerações sobre o seu curso posterior mas também do grau de integração com os fornecedores de componentes, o compartilhamento de informações e know-how com e entre as empresas, estrutura industrial e uma ampla gama de outros fatores anteriores" (MENELL, 2003, p. 136).
\end{abstract}

A propósito, sobre essa relação de integração de fornecedores de componentes dos produtos fabricados, importante lembrar a divisão do trabalho hoje que é internacional. Para os autores da administração de empresas e economia, a tarefa da produção hoje não está apenas dividida entre trabalhadores e fabricantes próximos geograficamente, mas em regiões diversas de países diversos. A cadeia produtiva da globalização recebe o nome da já mencionada global value chain, em que os países acabam por se especializar na produção de determinadas partes. A nosso ver, essa divisão acaba por atender a outro objetivo das grandes empresas transnacionais, que é a de impedir essa difusão das inovações, mantendo os fornecedores afastados, e especializados em um componente específico, fazendo com que uma determinada fábrica terceirizada não tenha a possibilidade de reter o conhecimento do processo de produção integral da mercadoria.

A instituição de monopólio sobre as invenções e inovações tecnológicas, assim, seja na forma de patentes, seja na forma do segredo industrial, é impeditivo para a difusão da inovação em muitos setores da indústria que poderia gerar benefícios sociais mais amplos.

A visão tradicional, no entanto, em especial no campo jurídico, sustenta pelos benefícios do monopólio da propriedade intelectual, ainda que evidências econômicas apontem o contrário. Mas reconhecem esse monopólio como causa eficiente para a detenção do poder. 
Para Luiz Otávio Pimentel (1999, p. 81), “a economia mundial é a estrutura na qual a patente é um elemento importante", e neste processo o Direito, como conjunto de regras torna possível a competição. Neste ambiente de Estados, organismos internacionais e as empresas transnacionais, um importante papel tem a Organização Mundial do Comércio:

"Nesse processo, portanto, cabe à OMC a administração da liberalização do comércio e da justa concorrência no mercado, contexto em que a tecnologia patenteada é uma das vantagens comparativas buscada com unhas e dentes pelos agentes econômicos que atuam globalmente: possuí-la significa deter um monopólio legal, uma fatia do comércio" (PIMENTEL, 1999, P. 82).

Ainda para Pimentel (1999, p. 86) a tecnologia patenteável traz a supremacia militar, segundo a leitura que faz do Professor Fabio Konder Comparato:

\footnotetext{
"COMPARATO, ao analisar o tema da transferência empresarial de tecnologia, afirma que é generalizado, nestes últimos cinquenta anos, o entendimento de que a tecnologia constitui um fator mais importante que o acúmulo de capitais para o aumento da produtividade empresarial. Por isso, o fator determinante do crescimento econômico e da supremacia bélica não é, como pensavam os teóricos do século passado, a acumulação de capital e a extensão territorial, mas a acumulação de saber e de tecnologia. A ciência e a técnica são, hoje, os instrumentos decisivos do imperialismo econômico e militar, e a sua preservação depende, em boa parte, da aplicação de uma severa política de segredo e reserva. E a reserva é feita justamente pelo instituto da patente, privilégio cujo instrumento tem o status de título de propriedade industrial" (PIMENTEL, 1999, p. 86).
}

O domínio da tecnologia que faz o trabalho ser mais produtivo, poupa tempo e facilita o trabalho não confere ao país que atinge o grau mais elevado apenas o domínio econômico, mas também o poder político e militar, o que permite que este poder político e militar ajude a promover ainda mais o poder econômico. Esse ciclo de poder explica, em parte, a razão dos pouquíssimos países que detêm a maior parte da riqueza mundial serem também as maiores detentoras do poder militar. E observamos esses mesmos países serem detentores da maior parte das patentes mundiais. 
Tabela 3 - Quadro comparativo de PIB, Poder Militar e Patentes

\begin{tabular}{|c|c|c|c|}
\hline & $\begin{array}{l}\text { Maiores economias } \\
(2019)-\mathrm{i}\end{array}$ & $\begin{array}{lr}\text { Maiores } & \text { poderes } \\
\text { militares } & (2019)-\mathrm{ii}\end{array}$ & $\begin{array}{l}\text { Maiores detentores } \\
\text { de patentes em } \\
\text { vigor (2017) - iii }\end{array}$ \\
\hline $1^{\circ}$ & Estados Unidos & Estados Unidos & Estados Unidos \\
\hline $2^{\circ}$ & China & Rússia & $\begin{array}{l}\text { China (Japão em } \\
\text { 2016) }\end{array}$ \\
\hline $3^{\circ}$ & $\begin{array}{l}\text { Japão (Alemanha em } \\
\text { 2017) }\end{array}$ & China & $\begin{array}{l}\text { Japão }\left(\text { China }^{36} \text { em }\right. \\
\text { 2016) }\end{array}$ \\
\hline $4^{\circ}$ & $\begin{array}{l}\text { Alemanha (Japão em } \\
\text { 2017) }\end{array}$ & Índia & $\begin{array}{l}\text { Reino Unido } \\
\text { (Coréia do Sul em } \\
\text { 2016) }\end{array}$ \\
\hline $5^{\circ}$ & $\begin{array}{l}\text { Índia (França em } \\
\text { 2017) }\end{array}$ & $\begin{array}{l}\text { Japão (França em } \\
\text { 2017) }\end{array}$ & $\begin{array}{l}\text { Coréia do Sul } \\
\text { (Alemanha em } \\
\text { 2016) }\end{array}$ \\
\hline $6^{\circ}$ & Reino Unido & $\begin{array}{l}\text { Coréia do Sul (Reino } \\
\text { Unido em 2017) }\end{array}$ & $\begin{array}{l}\text { Alemanha (França } \\
\text { em 2016) }\end{array}$ \\
\hline $7^{\circ}$ & $\begin{array}{l}\text { França (Itália em } \\
\text { 2017) }\end{array}$ & $\begin{array}{l}\text { França (Coréia do } \\
\text { Sul em 2017) }\end{array}$ & $\begin{array}{ll}\text { França } & \text { (Reino } \\
\text { Unido em } & 2016) \\
\end{array}$ \\
\hline $8^{\circ}$ & $\begin{array}{lll}\text { Itália (Brasil em } \\
\text { 2017) }\end{array}$ & $\begin{array}{l}\text { Reino Unido (Japão } \\
\text { em 2017) }\end{array}$ & $\begin{array}{l}\text { Itália (Rússia em } \\
\text { 2016) }\end{array}$ \\
\hline $9^{\circ}$ & $\begin{array}{l}\text { Brasil (Canadá em } \\
\text { 2017) }\end{array}$ & $\begin{array}{l}\text { Egito (Turquia em } \\
\text { 2017) }\end{array}$ & $\begin{array}{l}\text { Rússia (Suíça em } \\
\text { 2016) }\end{array}$ \\
\hline $10^{\circ}$ & $\begin{array}{l}\text { Canadá (Espanha em } \\
\text { 2017) }\end{array}$ & $\begin{array}{l}\text { Brasil (Alemanha } \\
\text { em 2017) }\end{array}$ & $\begin{array}{l}\text { Suíça (Canadá em } \\
\text { 2016) }\end{array}$ \\
\hline
\end{tabular}

i - Fonte: Banco Mundial (https://blogs.worldbank.org/publicsphere/world-s-top-100economies-31-countries-69-corporations)

ii - Fonte: Globalfirepower.com. O site utiliza mais de 50 critérios de meios convencionais como poderio militar efetivo, financiamento das formas armadas, capacidade de logística e geografia.

iii - Fonte: Organização Mundial da Propriedade Intelectual (http://www.wipo.int/edocs/pubdocs/en/wipo_pub_941_2017-chapter2.pdf)

Elaboração do autor.

Observamos que os Estados Unidos são a maior economia e o maior poder militar e ainda que ocupe o primeiro lugar nas patentes (em patentes em vigor, porque há 20 anos, prazo de validade da patente, a China quase não tinha registros de patentes) é tida hoje como a segunda potência em patentes. A China, a segunda economia do mundo e terceira potência militar, é a primeira nação em pedidos de patentes e de registros de

\footnotetext{
${ }^{36}$ A China alcançou os Estados Unidos e é o país que mais recebe pedidos de registros de patentes. Nesta lista aparece em $3^{\circ}$ lugar porque a patente tem prazo de validade de 20 anos. Quando se fala, portanto, em patentes em vigor, se contabiliza as patentes deferidas nos últimos 20 anos aproximadamente, ou seja, todas que estão em vigor na data da aferição.
} 
patentes concedidos desde 2012, em um crescimento exponencial constante (Tabela 9), de modo que deverá se tornar, em breve, a maior detentora de patentes em vigor no mundo, conforme as patentes antigas dos Estados Unidos vão caindo em domínio público. A sobressalência destas duas nações é notória.

É possível colocar em dúvida se o poder econômico ajuda a promover a geração de inovação que resulta em patentes, ou se o ambiente de inovações ajuda a promover o poder econômico. Do que se apreende da literatura é que ocorre os dois fenômenos concomitantemente, e que o poder econômico atua politicamente na proteção das inovações pelo direito de marcas e patentes, efetivando-se uma restrição do conhecimento que se torna indisponível aos demais países que perseguem o desenvolvimento.

O fenômeno do poderio militar que resulta do poder do conhecimento tecnológico ou ao menos uma relação entre esses poderes fica claro pela Tabela 2.

Há muito tempo (em 1935) Bertrand Russel já anunciava

\begin{abstract}
"O grau de dependência das transações econômicas em relação à força armada não é geralmente percebido. A riqueza é adquirida, em parte, através da habilidade nos negócios, mas esta habilidade só pode florescer em um ambiente de poderio militar e naval. Foi com o uso da força armada que os holandeses tomaram Nova York dos índios, que os ingleses a tomaram dos holandeses, os americanos dos ingleses. [....] Este processo é de alguma forma disfarçado, mas nos bastidores a ameaça da guerra está sempre à espreita e é esta ameaça latente que garante as negociações (RUSSEL, 2002 p. 64-65).
\end{abstract}

Paul Kennedy (1989, p. 14) em seu estudo sobre a ascensão e queda das grandes potências ao longo da história, por exemplo, ao constatar que se tomado o ano de 1500 seria difícil vislumbrar que a Europa viria a ser a região dominante do mundo por pelo menos nos quinhentos anos seguintes, afirma que é preciso entender os pontos positivos e negativos da Europa e das civilizações que detinham um poder extraordinário naquele período e que se mostravam como prováveis impérios dominantes, como a China e o Islã, e em certo grau também o Japão e a Rússia.

Nessa análise de pontos positivos e negativos que ajudam a explicar a ascensão e a queda das potências, o tema central para Kennedy (1989) é sempre o poderio militar e a tecnologia que acompanha esse poder. No caso da Europa, ressalta inicialmente a inexistência de um poder centralizado no período que dominasse todo o continente, 
apontando inclusive a base territorial do continente, fragmentada recortada por povos, florestas, cadeias montanhosas e rios.

Um outro fator da causa da ascensão europeia teria sido a competição interna dos poderes regionais, competição essa que também ocorria no Japão, o que levou à dispersão do conhecimento da tecnologia de armamentos militares entre esses grupos regionais. A Suíça, por exemplo, dispunha de uma grande tecnologia que vendia para quem pagasse.

Se por um lado essa dispersão tecnológica militar impediu que uma potência única se sobressaísse e subjugasse as demais do continente europeu, por outro lado promoveu uma competição que Kennedy (1989, p. 31) chamou de "uma forma primitiva de corrida armamentista entre as cidades-estados e, em seguida, os reinos maiores”. E

"O aspecto mais positivo dessa crescente rivalidade comercial e colonial foi a espiral ascendente do conhecimento que surgiu paralelamente - na ciência e tecnologia. Sem dúvida, muitos progressos dessa época foram subprodutos da corrida armamentista e da luta pelo comércio além-mar; as vantagens finais, porém, transcenderam suas origens inglórias. Melhor cartografia, melhores tábuas de navegação, novos instrumentos como o telescópio, barômetro, quarto inglês e bússola de marinha e melhores métodos de construção naval ajudaram a tornar a viagem marítima menos imprevisível. Novas colheitas e plantas não só proporcionavam melhor alimentação, como também foram um estímulo para a botânica e a ciência agrícola. O conhecimento da metalurgia, e na verdade de toda a indústria do ferro, fez progressos rápidos, o mesmo acontecendo com as técnicas de mineração profunda. Astronomia, medicina, física e engenharia também se beneficiaram com a intensificação do ritmo econômico e a maior valorização da ciência. O espírito indagador e racionalista observava mais e experimentava mais; as máquinas impressoras, além de produzirem Bíblias e tratados políticos no vernáculo difundiam as novas descobertas. O efeito cumulativo dessa explosão do conhecimento foi fortalecer ainda mais a superioridade tecnológica - e portanto militar, da Europa. (Kennedy, 1989, p. 37).

Em recente relatório da Secretaria de Estado dos Estados Unidos divulgado no mês de novembro de 2020, tratando do enfrentamento do "Desafio Chinês"37, o documento coloca dez pontos iniciais a serem perseguidos pelos Estados Unidos em seu enfrentamento com a China, e como política externa na defesa da liberdade. O segundo

\footnotetext{
${ }^{37}$ No original "The Elements of the China Challenge". Disponível em: https://www.state.gov/wpcontent/uploads/2020/11/20-02832-Elements-of-China-Challenge508.pdf?fbclid=IwAR2Fxv4ScMMSnMevUmi_VEJE3p9y_wazVAHC_Yp7iFXEkbV_Nuq2U104SLM. Acesso em 17/11/2020.
} 
ponto é "Os Estados Unidos devem manter o mais ágil e sofisticado tecnologicamente poder militar, ao mesmo tempo reforçando a cooperação de segurança, baseado em interesses comuns e responsabilidade compartilhada, com aliados e parceiros".

Volta a repisar no sétimo ponto que os Estados Unidos devem treinar os servidores públicos em "diplomacia, assuntos militares, finanças, economia, ciência e tecnologia e outros campos" e pensadores especialistas em China a fim de que "tenham fluência na língua, e adquira conhecimento extenso e da cultura e história”. Na nona recomendação, o Departamento de Estado norte-americano afirma que se deve reformar a educação, e entre outros entendimentos, "preparar os estudantes para fazer frente às demandas complexas da era da informação, economia globalizada para expertise em ciência, tecnologia, engenharia e matemática".

Procurando compreender o comportamento do governo chinês e do partido comunista, o documento afirma que, aproveitando a modernização e o desenvolvimento chinês, o Partido Comunista Chinês busca dominar a economia global com a liderança nas ciências de ponta e uma revolução da alta tecnologia" (2020, p.10). Afirma que a China rouba propriedade intelectual, na maior "transferência ilegítima da história humana, roubando inovação tecnológica, segredos comerciais de empresas, universidades e dos setores de defesa dos Estados Unidos e outras nações".

A importância da tecnologia, portanto, é inegável e se encontra como questão prioritária para qualquer governo que pense em termos de políticas de Estado e a busca por soberania.

Essa importância nos investimentos que são destinados por empresas e estados à pesquisa e desenvolvimento já vem de algum tempo, principalmente na última metade do século XX e mais acentuadamente a partir dos anos 1970. Para François Chesnais (1994, p. 117) as novas relações entre ciência, tecnologia e atividade industrial especialmente neste período, tornou a tecnologia um fator de competitividade decisivo. Os gastos das empresas do setor industrial em pesquisa e desenvolvimento se tornaram essenciais e levam a um alto índice de concentração de rendas nas empresas que assim procedem e que, setorialmente sem mostram das mais altas concentrações do mundo. Através de coalizões mundiais com determinados países, que se constituem em oligopólios, as empresas intercambiam seus conhecimentos para a aceleração do desenvolvimento criando mecanismos de apropriação e proteção desse acervo com a ajuda do Estado. Os projetos VHSIC e Sematech dos Estados Unidos, o projeto VLSI e do computador de quinta geração, e dos projetos europeus Esprit, CE e Jessi são citados 
por Chesnais (1994, p. 119) como exemplos de programas conhecidos nos anos 1980 na área da indústria eletrônica.

No caso das patentes de invenções, é importante observar que é um dos critérios de medição do desenvolvimento econômico, mas não o único, uma vez que nem todos os setores da economia se utilizam da proteção de suas tecnologias pela via da patente. No entanto, entendemos que se trata de um poderoso instrumento de medição pelo alto grau de competitividade nos dias atuais (revelado pelo aumento dos litígios) e pela grande importância que empresas e governos têm dado ao tema da propriedade intelectual e as infrações a esses direitos.

Os conhecimentos tecnológicos essenciais que sustentam o poder econômico são então protegidos pelo Estado através da concessão do direito de patente. Um direito de exclusividade no uso daquela determinada tecnologia. Cria-se assim um monopólio da tecnologia em detrimento do acesso público ao conhecimento. Em nosso entender esse monopólio impede a livre concorrência e gera para muitas das áreas tecnológicas menos eficiência no desenvolvimento geral do mercado, já que muitas inovações permanecem fechadas ao uso e compartilhamento.

Nossa afirmação, portanto, destoa do pensamento geral que fundamenta o direito de patentes como um direito necessário para proteger o investimento na pesquisa e incentivar o progresso tecnológico. Como aponta Calixto Salomão Filho (2015, p. 123) "A ciência progride através de inovações e grandes ideias. Mas enquanto essas não vêm, formam-se durante anos consensos muitas vezes irrefletidos e por vezes com escasso apoio na realidade dos fatos".

Para Salomão Filho (2015) é possível se fazer duas leituras dos direitos de patentes, referindo-se a uma leitura privatista e a outra publicista desse direito, nesta segunda baseando-se no direito concorrencial:

\footnotetext{
"Ocorre que é possível uma compreensão diametralmente oposta do mesmo fenômeno. A compreensão concorrencial do direito industrial torna tudo mais simples. Amplia e torna pública a disciplina exatamente porque tira o foco dos requisitos para a concessão e centra-se na disciplina do abuso do direito. A patente, como qualquer situação de poder no mercado, pode gerar abusos, que devem ser coibidos. $O$ direito industrial passa, então, a incluir nesse aspecto uma disciplina específica do abuso de poder" (SALOMÃO FILHO, 2015, p. 132).
}

Observamos que todos os países hoje considerados desenvolvidos demoraram para adotar legislações de propriedade intelectual. Ha Joon Chang (2002) demonstra que 
o Reino Unido, a Suíça, a Holanda, a Alemanha apenas adotaram legislação protegendo as marcas e patentes quando já tinham atingido um alto grau de industrialização e já tinham indústrias nacionais competindo em condições de igualdade com suas congêneres estrangeiras. A China adotou legislação de patentes para proteção das invenções tecnológicas em 1984, passando a vigorar em 1985 e emendada em 1992, 2000 e 2008, seguindo o mesmo padrão internacional, estabelecendo como requisitos para patenteamento os critérios de novidade, inventividade e aplicação prática ${ }^{38}$.

Essa a conclusão de trabalho anterior (ANDAKU, 2016) que procurou demonstrar que os direitos de propriedade industrial, dentre as quais se incluem as marcas e patentes, ao criar monopólios, não estão a incentivar o desenvolvimento tecnológico como é preconizado pelos teóricos predominantes do Direito ou da Economia. Ao contrário, entendemos que em um ambiente em que não houvesse direito de patentes e a concorrência fosse livre, na maior parte dos ramos industriais, as tecnologias teriam uma dinâmica e um desenvolvimento mais amplo e mais rápido.

Essa lógica prevalecente no mundo jurídico e econômico, encontra o questionamento de uma voz solitária. Para Jean Tirole:

"Com efeito, se, como quer a lógica, a propriedade intelectual é apenas um mal necessário, visando dar incentivos à $\mathrm{P} \& \mathrm{D}$ ou à criação artística, convém que ela permaneça fiel a esse objetivo. Ora, em se tratando de investimento já efetuados, um reforço da propriedade intelectual não tem nenhum efeito incitativo: é tarde demais! O reforço reduz a difusão sem contribuir para a criação" (TIROLE, 2020, p. )

Uma das maiores empresas hoje de tecnologia do mundo, o Google, agiu desta forma aberta no que toca o conhecimento e a inovação, como relatam pessoas que participaram de sua construção. Schmidt e Rosenberg (2015, p. 104) afirmam: "Em geral, as plataformas escalonam mais rápido quando são abertas. Veja a maior plataforma de todas, a internet”. E seguem com diversos exemplos, o da própria rede de computadores (internet), da AT\&T, empresa de telefonia estagnada no início da internet até fazer suas adaptações e abrir sua plataforma, quando a inovação voltou, o computador pessoal da IBM, da Microsoft e Intel.

E então explicitam:

“'Aberto' pode ser um termo bem ao estilo Rashomon - empresas diferentes o definirão de maneiras distintas para que seja compatível com seus próprios objetivos. No entanto, em geral, uma plataforma

\footnotetext{
${ }^{38}$ No Brasil a Lei de Propriedade Industrial (Lei 9.279/96) estabelece os termos da novidade, atividade inventiva e aplicação industrial.
} 
aberta significa compartilhar mais propriedade intelectual, como código de programação ou resultados de uma pesquisa, aderir a padrões abertos em vez de criar os próprios e dar aos consumidores a liberdade de sair dela com facilidade, Isso pode parecer uma heresia para o pensamento tradicional, estilo MBA, que dita que você deve construir uma vantagem competitiva sustentável sobre os concorrentes e depois trancar a fortaleza e defende-la com óleo fervente e flechas incendiárias" (SCHIMDT E ROSENBERG, 2015, p. 105).

É importante destacar, por outro lado, que para alguns casos de plataformas digitais e softwares, uma segunda intenção pode estar por trás desta eventual abertura, perceptível em um primeiro momento como mais "democrática". Lembremos do caso do pacote "Office" da Microsoft, tolerante na reprodução e compartilhamento do software no início, até que quase todos, em praticamente todo o mundo, estivessem acostumados com os editores de texto (word) e de planilha (excel) para então passar a cobrar pelo uso, fiscalizar com mais rigor e aumentar os preços. A abertura, portanto, algumas vezes, visa um segundo momento mais lucrativo para as empresas, devendo ser analisada com cuidado no contexto da competição entre empresas. 


\section{Capítulo 7}

\section{Geopolítica de patentes e concorrência no centro do sistema capitalista}

No âmbito da Organização Mundial do Comércio se observa uma quantidade enorme de disputas envolvendo os Estados Nacionais, em reclamações em virtude de políticas públicas internas, legislações e medidas nacionais que, alegando-se infrações de normas internacionais, se constituiriam em prejuízo aos nacionais dos países reclamantes. São centenas de demandas envolvendo produtos, serviços e com destaque também para alegadas infrações aos direitos de propriedade intelectual, dentre as quais as patentes. Em outubro de $2020^{39}$ observa-se no site da entidade 11 disputas envolvendo patentes (entre vários países sendo partes principais ${ }^{40}$ a Índia, por duas vezes, Canadá duas vezes, Argentina duas vezes, Paquistão, Portugal, União Européia, Brasil e Estados Unidos). Duas disputas envolvendo produtos farmacêuticos (Índia e Brasil com a União Europeia). Dez casos envolvendo Direitos autorais (Japão aparece 2 vezes, a União Europeia aparece duas vezes, e Brasil, Estados Unidos, China, Grécia, Suécia, Dinamarca e Irlanda ). Quatro disputas envolvendo Indicações Geográficas (3 vezes a Austrália e 1 a União Européia). Uma disputa envolvendo a Lei de Tarifas de 1930 em que a União Europeia demanda contra os Estados Unidos. Nove disputas envolvendo marcas empresariais (entre vários países sendo partes principais a Austrália por cinco vezes, os Estados Unidos, A União Européia, a China e a Indonésia). Cinco disputas envolvendo propriedade intelectual em geral (envolvendo diversos países sendo partes principais duas vezes a Arábia Saudita, uma o Bahreim, uma os Emirados Árabes e uma a China). Uma disputa entre a União Europeia e a China envolvendo informações de serviços financeiros e fornecedores.

Estes casos não são, na verdade, os únicos casos envolvendo propriedade intelectual, por se tratar de um quadro com mera classificação das disputas por tema principal. Sob o quadro de disputas sobre produtos ou sobre serviços, por exemplo, existem casos cujo litígio recaem indiretamente sobre aspectos de propriedade intelectual.

\footnotetext{
${ }^{39}$ Muitas dessas disputas já se encontram resolvidas por acordos, mas o procedimento continua a constar no histórico porque podem ser retomadas em virtude de descumprimento dos acordos ou decisões. Disponível em: https://www.wto.org/english/tratop_e/dispu_e/dispu_subjects_index_e.htm . Acesso em 07/10/20.

${ }^{40}$ Um país pode abrir uma disputa contra vários outros países ou vários países podem abrir uma disputa contra um único país ou vários deles por infrações cometidas.
} 
Sob a classificação de disputas envolvendo serviços de telecomunicações por exemplo, encontramos uma reclamação dos Estados Unidos contra o México em que acusavam o país latino-americano de manter medidas de proteção a empresas locais na prestação de serviços de telecomunicações (DS-204 ${ }^{41}$ - resolvido por acordo em junho de 2004). Tratase de uma área com claras repercussões de direitos autorais e patentes, embora o fundamento da reclamação recaísse sobre serviços. Neste procedimento se encontraram ainda como terceiros interessados a Austrália, Brasil, Canadá, Cuba, Comunidade Europeia, Guatemala, Honduras, India, Japão e Nicarágua.

Da mesma forma, na classificação de disputas sob o tema de produtos agrícolas se encontram 32 disputas, sendo que a de número DS 291 (resolvida por acordo em março de 2004), patrocinada pelos Estados Unidos contra comunidades europeias, envolveu reclamação de ilegalidade em barreiras a produtos agrícolas americanos. Nesta demanda estavam ainda envolvidos como terceiros interessados a Argentina, Austrália, Brasil, Canadá, Chile, China, Formosa, Colômbia, El Salvador, Honduras, México, Nova Zelândia, Noruega, Paraguai, Peru, Tailândia e Uruguai. Destacamos aqui que a agricultura hoje é impulsionada por uma técnica conhecida como "Cultivar de Plantas", que se trata de uma propriedade intelectual, semelhante a uma patente, específica para o desenvolvimento de sementes e plantas em técnica próxima à biotecnologia. Cultivar é a denominação brasileira, sendo que a Organização Mundial da Propriedade Intelectual e em países de língua inglesa se denomina "plant variety protection" ou "plant breeder's right" e é definida como "uma forma de direito de propriedade intelectual que concede ao criador de uma nova variedade de planta em relação a certos atos referentes à exploração da variedade protegida que requer autorização prévia do criador. Como no caso das patentes, marcas e desenhos industriais, exame prévio e concessão pela autoridade relevante é um requisito para estabelecer o direito do criador ${ }^{42}$ ".

"Trancar a fortaleza e defende-la com óleo fervente e flechas incendiárias" (SCHIMDT e ROSEMBERG, 2015) é o que as empresas transnacionais e seus governos tem feito desde sempre, ou pelo menos desde o final do século XIX, após as feiras e

\footnotetext{
${ }^{41}$ Dispute Setlement no original, que poderíamos traduzir por processo, procedimento ou demanda.

${ }^{42}$ Em tradução livre do autor. No original: "Plant variety protection, also called a "plant breeder's right," is a form of intellectual property right granted to the breeder of a new plant variety in relation to certain acts concerning the exploitation of the protected variety which require the prior authorization of the breeder. As in the case of patents, trademarks and industrial designs, prior examination and granting by the relevant authority is required to establish the breeder's right." Disponível em: https://www.wipo.int/edocs/mdocs/sme/en/wipo_ip_bis_ge_03/wipo_ip_bis_ge_03_11-main1.pdf. Acesso em 07/10/20.
} 
exposições de ciências se mostrarem eventos propícios à cópia e pirataria tecnológica, resultando nas Convenções Internacionais para a Proteção da Propriedade Industrial de Paris (1883) e da Proteção dos Direitos Autorais (Berna 1886), reforçando-se aproximadamente cem anos depois quando um acompanhamento maior de proteção dos direitos em todo o espaço mundial se tornou possível com o Acordo Trips, fazendo de um regime de proteção internacional um regime global.

E neste quadro que as estatísticas demonstram uma alta concentração do poder geopolítico e econômico (e de patentes) em poucos países do centro do sistema (Estados Unidos, Japão, Coréia do Sul, Europa Ocidental, agora a China e a Rússia), em detrimento de todo o restante ou quase duas centenas de nações do mundo. E ainda assim ocorre uma grande competição entre esses países centrais e suas empresas. Essa competição é expressa quando pensamos nas chamadas "guerras de patentes". Existem dezenas de ações judiciais em tribunais de várias nações do mundo entre essas empresas transnacionais a que vimos nos referindo. Anunciou-se no início de 2018 o fim de uma das ações envolvendo a empresa Apple e a Samsung, no campo dos telefones celulares, em que a última pagaria à primeira a importância de US\$ 539 milhões de dólares, em acusação que envolvia violação de patentes e marcas comerciais ${ }^{43}$.

No campo dos litígios envolvendo não os Estados nacionais mas as empresas, observamos uma crescente demanda nos tribunais em todo o mundo. Nos Estados Unidos ${ }^{44}$ há um grande crescimento a partir de 1996, de aproximadamente 2 mil casos envolvendo patentes subindo para mais de 6 mil casos em 2013, e depois caindo em 2018 para 3.694. Em relação a marcas empresariais, as disputas se mantêm em nível estável. De 3035 em 1996 para 3221 em 2018, sem grandes saltos neste período.

Nos Tribunais Chineses, conseguimos extrair dados apenas dos tribunais superiores, ou seja, casos não resolvidos em primeira instância por acordo, por exemplo, sobretudo em sua Suprema Corte, em que aparecem 30 disputas envolvendo propriedades intelectuais ${ }^{45}$, sendo 10 de marcas empresariais e 3 de patentes (sendo as demais sobre cultivares- espécie de patente para o campo agrícola, desenho industrial, modelo de utilidade - uma espécie de quase patente, direitos autorais e concorrência desleal).

\footnotetext{
43 Disponível em: https://targethd.net/fim-da-guerra-de-patentes-e-samsung-tem-que-pagar-mais-us-539milhoes-para-a-apple/. Acesso em 12/06/2018.

${ }^{44}$ Disponível em: https://www.uscourts.gov/news/2020/02/13/just-facts-intellectual-property-casespatent-copyright-and-trademark. Acesso em 10/12/2020.

${ }^{45}$ Disponível em: https://wipolex.wipo.int/en/judgments/results?countryOrg=CN. Acesso em 10/12/2020.
} 
Em uma busca no site wikipedia ${ }^{46}$ encontramos 149 disputas judiciais envolvendo patentes de telefonia celular entre as empresas Sony Mobile, Apple Inc., Samsung, Microsoft, Nokia, Motorola, Huawei, LG Eletronics, ZTE e HTC. No capítulo próprio sobre telefonia celular (Capítulo 10) analisamos algumas dessas disputas.

As principais disputas judiciais envolvendo patentes vem acontecendo desde 2009, quando o aparelho de telefone celular ganhou os contornos atuais de se tornar um aparelho "inteligente", o tal smartphone. Disputas envolvendo marcas, design e outras propriedades intelectuais (trade dress, concorrência desleal) acontecem desde a década passada. A corrida entre as grandes empresas é acirrada.

Um litígio interessante de ser observado é o que envolveu a Apple e a HTC (High Tech Computer Corp), empresa taiwanesa em 2010, na Corte do Distrito de Delaware. A Apple acusou a HTC de violar vinte patentes relacionadas à interface de arquitetura e hardware do iPhone. A HTC se defendeu acusando a Apple de ter violado quatro patentes da HTC que havia licenciado do Google. O litígio acabou em acordo, em que se estabeleceu pagamento de licenças de parte a parte por dez anos. Em 2010, Taiwan, ou Formosa já vivia uma boa relação com a China e já se constituía em um cluster de desenvolvimento tecnológico também.

Huntington (2010) afirma que a China a partir dos anos 1990 iniciou uma fase de coprosperidade asiática, se estabelecendo como centro, em virtude de boas e efetivas relações comerciais advindas de uma etnia comum com chineses estabelecidos em outros países da região, inclusive em Taiwan, a partir do qual clusters de desenvolvimento tecnológico iam se firmando. A HTC pode ser um bom exemplo dessa afirmação. A HTC se apresenta como uma empresa fundada em 1997, com sede em Nova Taipei e que produz smartphones e tablets ${ }^{47}$.

\footnotetext{
${ }^{46}$ Disponível em: https://en.wikipedia.org/wiki/Smartphone_patent_wars. Último acesso em 23/12/2020.

${ }^{47}$ Disponível em: https://www.htc.com/us/about/. Acesso em 25/12/2020.
} 


\section{Capítulo 8}

\section{A relação entre marcas empresariais com a patente e a inovação.}

A segunda parte deste trabalho se dedica às patentes como indicadores de inovação e desenvolvimento tecnológico. Sustentamos que as patentes se constituem nos principais medidores econômicos e armas das empresas e países para a conquista do poder econômico e político ao lado da exploração das marcas. As marcas, de fato, não se sustentam sem que novos produtos e serviços estejam sempre se aprimorando e avançando no estado da técnica. Do aumento de registros de marcas se deduz basicamente um aumento de diversidade de mercadorias postas no mercado e, ou, o aumento de produtores, mas não necessariamente o aprimoramento dos produtos, já que as novas marcas podem se referir a produtos já existentes sob outra roupagem produzidos pelas mesmas ou novas empresas. Cabe neste interim, assim, voltar às marcas empresariais para questionar se as marcas guardam alguma relação direta com as patentes e vice-versa, ou sobre a inovação e no consequente desenvolvimento.

Para Figueiredo (2014, p. 22) a "associação entre marca e inovação não é direta. Afinal, o único requisito para o registro de uma marca é a novidade do símbolo em si, mas não do produto (como no caso das patentes)". Ainda para a autora a aplicação de investimentos em pesquisa para inovação de produtos se torna necessária para manter a fidelização dos consumidores, que acompanham as inovações e se beneficiam dela.

Não são muitos os estudos que aprofundam o tema de uma relação direta entre marcas e patentes. Malberg e Claes (2018) analisaram indústrias do setor eletromecânico, automotivo e farmacêutico na Suécia para saber se as estatísticas de registros de marcas empresariais podiam ser usados como indicadores de inovação das empresas industriais. Chegaram à conclusão de que para as primeiras duas, os indicadores de registros de marcas empresariais não são confiáveis para tal propósito. Já para a indústria farmacêutica sueca, os resultados foram diferentes. A comparação entre marcas e novos produtos mostraram que uma alta e estável porcentagem de novos produtos foram registrados como marcas novas. O número de novas marcas também se mostrou compatível com o número de novas drogas registradas e aprovadas no período de 1935-1996. De todo modo, é interessante notar que os autores sustentam que um único medidor (patentes) não dá conta de medir a inovação integralmente e que o uso de medidores diferentes combinados se mostra um caminho promissor, principalmente se podem ser medidos por períodos 
prolongados. Mais uma razão aqui de se usar das marcas empresariais como objeto de estudos, ao lado das patentes.

No Brasil encontramos um estudo que procurou saber como as marcas e patentes criam valor para as empresas. Teh, Kayo e Kimura (2008) buscaram saber se as marcas e as patentes são ativos na criação de valor quando consideradas especificamente as empresas brasileiras. Os autores partiram do pressuposto que ambas as espécies de propriedade intelectual agem como inovação, mas observando que a patente resulta de investimentos em pesquisa e desenvolvimento, e a marca como ativo de relacionamento, ambas importantes na criação de valor.

Com uma pesquisa descritiva e qualitativa com base em empresas de capital aberto com ações na Bolsa de Valores de São Paulo, os autores (TEH, KAYO e KIMURA, 2008) relatam que para o caso das empresas estudadas a "patente não contribui para a criação de valor das empresas brasileiras analisadas, o que pode ter uma explicação estrutural. No Brasil, ao contrário de outros países mais desenvolvidos, é muito baixo o nível de investimento em pesquisa e desenvolvimento”. Já a marca representou um aspecto importante na criação de valor: "Em todos os modelos analisados, a variável quantidade de marcas tem relação positiva e significativa com a variável dependente (tanto o valor de mercado sobre o valor contábil quanto o q de Tobin)".

A partir desta análise procuramos estabelecer uma "equação" de uma possível relação direta entre marcas e patentes e elaboramos duas tabelas, uma de pedidos de patentes e outra de pedidos de marcas, dos dois países aqui focados (Estados Unidos e China), mais um país com alto índice de industrialização (Suíça) e dois países em desenvolvimento (Brasil e Argentina). No caso da Argentina o tomamos para esta análise não apenas por se tratar de um país vizinho, mas porque sabemos se tratar de um país com muitas marcas, sobretudo no campo da indústria têxtil, mas de uma industrialização decrescente nas últimas décadas.

Tabela 4 - Pedidos de patentes em cada país por nacionais de cada país, englobando os pedidos de patentes no país e fora do país ${ }^{48}$.

\begin{tabular}{|c|c|c|c|c|c|}
\hline $\begin{array}{l}\text { Pedidos } \\
\text { de } \\
\text { Patentes }\end{array}$ & Brasil & EUA & China & Suíça & Argentina \\
\hline 2009 & 5.423 & & 229.096 & & 952 \\
\hline 2010 & 5.737 & 433.140 & 293.066 & 39.459 & 969 \\
\hline
\end{tabular}

48 * Não incluem os estrangeiros que fazem pedidos de patentes nesses países: 


\begin{tabular}{l|l|l|l|l|l}
\hline 2011 & 6.362 & 440.719 & 415.829 & 38.786 & 1.027 \\
\hline 2012 & 6.603 & 473.462 & 535.313 & 42.018 & 1.079 \\
\hline 2013 & 6.848 & 501.134 & 704.936 & 45.001 & 922 \\
\hline 2014 & 6.712 & 509.510 & 801.135 & 44.410 & 791 \\
\hline 2015 & 6.570 & 530.659 & 968.252 & 45.966 & 889 \\
\hline 2016 & 7.216 & 522.064 & 1.204 .981 & 47.121 & 1.143 \\
\hline 2017 & 7.505 & 525.467 & 1.245 .709 & 44.575 & 766 \\
\hline 2018 & 6.859 & 515.145 & 1.460 .246 & 46.661 & 755 \\
\hline 2019 & 7.409 & 521.145 & 1.327 .847 & 45.988 & 815 \\
\hline
\end{tabular}

Fonte: do autor a partir de dados colhidos no site da organização mundial da propriedade intelectual - www.wipo.com

Tabela 5. Pedidos de registro de marcas empresariais por nacionais de cada país, englobando pedidos no próprio país e no estrangeiro

\begin{tabular}{l|l|l|l|l|l}
\hline & Brasil & EUA & China & Suíça & Argentina \\
\hline 2009 & 111.297 & 1.040 .068 & 838.071 & 358.003 & 75.443 \\
\hline 2010 & 122.662 & 1.198 .782 & 1.113 .120 & 410.825 & 78.989 \\
\hline 2011 & 141.081 & 1.335 .791 & 1.445 .916 & 413.578 & 67.378 \\
\hline 2012 & 140.356 & 1.390 .564 & 1.694 .024 & 433.847 & 54.612 \\
\hline 2013 & 155.897 & 1.483 .556 & 1.940 .908 & 481.537 & 48.680 \\
\hline 2014 & 150.677 & 1.525 .002 & 2.422 .084 & 478.843 & 51.903 \\
\hline 2015 & 152.225 & 1.677 .570 & 3.100 .283 & 449.606 & 61.006 \\
\hline 2016 & 155.153 & 1.607 .522 & 4.192 .656 & 485.857 & 63.749 \\
\hline 2017 & 178.428 & 1.654 .453 & 6.388 .344 & 487.811 & 66.804 \\
\hline 2018 & 196.035 & 1.760 .207 & 8.118 .135 & 499.499 & 64.246 \\
\hline 2019 & 237.410 & 1.837 .368 & 8.577 .967 & 517.509 & 57.945 \\
\hline
\end{tabular}

Fonte: do autor a partir de dados colhidos no site da organização mundial da propriedade intelectual - www.wipo.com

O que logramos concluir é que todos os países exceto a Argentina tiveram aumento nos pedidos de registros de patentes e de marcas. Se fizermos uma relação direta de número de pedidos de marcas dividido pelo número de patentes encontraremos o seguinte:

a) Existem muito mais pedidos de registro de marcas do que de patentes em todos os países analisados.

b) Para o ano de 2019, no caso dos Estados Unidos há uma relação de 28,36\% de pedidos de patentes em relação à quantidade de pedidos de marcas e na China essa relação é de 15,47\%. Em 2018 a relação era de 29\% para Estados Unidos e 17\% para a China. No ano de 2015 essa proporção era de 31\% para os Estados Unidos 
e de $31 \%$ para a China. Em 2013 era de $33 \%$ para os Estados Unidos e 36\% para a China. Em 2010, a China tinha 26\% e os Estados Unidos tinham 36\%.

c) Estados Unidos e China mantiveram relação parecida de percentuais de patentes com marcas empresariais, até o ano de 2017 quando a China aumentou apenas 3,5 a sua quantidade de pedidos de patentes em relação a 2016 e o pedido de registro de marcas empresariais aumentou em torno de 55\%. Publicações da época viram esse salto como resultado de uma política governamental de "Ir para o Global" (Go global) com a proteção maior das marcas chinesas. A Organização Mundial da Propriedade Intelectual viu este salto como resultado de uma política governamental de dinamizar a economia, em um ambiente de incentivo a novos negócios com proteção das marcas ${ }^{49}$.

d) A relação de patentes por marcas é elevada para os dois países. Dos países aqui analisados a Suíça teve para o ano de 2019 uma relação de 8,9\% de patentes em relação a marcas registradas. Em 2010 a relação era de 9,6\%, mantendo-se semelhante nos demais anos.

e) No Brasil a relação de patentes por marcas empresariais foi, em 2019, de 3,12\% e na Argentina de 1,4\%. Em 2010, foi de 4,6\% para o Brasil e de 1,2\% para a Argentina.

Se consideramos que registros de patentes indicam inovação e desenvolvimento tecnológico e que marcas indicam diversidade de produtos no mercado, vamos concluir que Estados Unidos e China tem tido um alto grau de inovação em relação à sua diversidade de mercado, que a Suíça mantém um índice médio, e que Brasil e Argentina têm pouca inovação em relação à diversidade de seu mercado. 237 mil novas marcas ao ano no Brasil e 57 mil marcas na Argentina não são números desprezíveis para um período pós crise mundial (a de 2008).

Esses dados, nos parecem, confirmam a tese de que a hegemonia no campo tecnológico se concentrando no centro dinâmico da economia pode ser extraída pela análise das marcas e patentes, sendo esses direitos de propriedade intelectual instrumentos da manutenção dessa hegemonia. Confirmam a tese também que a China é uma potência consolidada nesse campo.

Tabela 6 - Relação percentual de patentes e marcas empresariais em 2019

\begin{tabular}{l|l|l|l}
\hline País & Pedidos de patentes & Pedidos de marcas & Percentual \\
\hline Coréia do Sul & 248.427 & 375.152 & $66,22 \%$ \\
\hline
\end{tabular}

49 Disponível em: https://www.wipo.int/wipo_magazine/en/2017/04/article_0005.html. Acesso em 28/12/2020. 


\begin{tabular}{l|l|l|l}
\hline Japão & 452.130 & 784.841 & $57,60 \%$ \\
\hline Estados Unidos & 521.145 & 1.837 .368 & $28,36 \%$ \\
\hline China & 1.327 .847 & 8.577 .967 & $15,47 \%$ \\
\hline Índia & 34.015 & 369.064 & $9,92 \%$ \\
\hline Suíça & 45.988 & 517.509 & $8,88 \%$ \\
\hline Alemanha & 178.184 & 2.341 .900 & $7,60 \%$ \\
\hline Indonésia & 3.141 & 51.053 & $6,15 \%$ \\
\hline França & 67.294 & 1.179 .830 & $5,70 \%$ \\
\hline África do Sul & 1.514 & 34.670 & $4,36 \%$ \\
\hline Brasil & 7.409 & 237.410 & $3,12 \%$ \\
\hline México & 2.534 & 142.421 & $1,77 \%$ \\
\hline Colômbia & 638 & 38.628 & $1,65 \%$ \\
\hline Vietnã & 838 & 84.403 & $0,99 \%$ \\
\hline
\end{tabular}

Fonte: Elaboração do autor a partir de dados obtidos no site da OMPI

Interessante notar que os quatro primeiros países da lista estão também entre os primeiros países da lista elaborada na Tabela 3, referente a poder econômico, militar e de patentes. Todos com índices de patentes por marcas empresariais superiores a dez por cento. Existe um segundo grupo com pedidos de patentes superior a 30 mil (Índia) e com mais de 2 milhões de marcas empresariais como Alemanha, cujo índice de relação se situam entre 9,92 e 5,70\%, a França. Países que também aparecem como potências na Tabela 3. Por fim, temos um terceiro grupo com índices inferiores a 5\%, todos eles emergentes. Esses índices, nos parecem guardam estreita relação com nosso postulado e se constituem em efetiva demonstração de que tais índices são medidores confiáveis do desempenho no desenvolvimento tecnológico e econômico. 


\section{Capítulo 9}

\section{Os Investimentos Estrangeiros Diretos}

Os investimentos estrangeiros diretos, que no mundo corporativo são denominados por sua sigla IED, frequentemente usados em sua denominação em língua inglesa como FDI (Foreign Direct Investments) são instrumentos jurídicos, de natureza econômica, em que as grandes corporações aportam recursos (não especulativos) nos outros países.

Para Lemoine (2009, p. 276) “Ao contrário dos investimentos em ações no mercado bolsista, os investimentos diretos supõem, na verdade, que a sociedade estrangeira tem um interesse duradouro na participação do capital a empresa local”, e que "Para atrair os investidores, concedem-se diversas vantagens fiscais, como as reduções do imposto sobre os lucros e a isenção de direitos alfandegários sobre algumas importações'.

Esses investimentos se dão em quadro jurídico internacional que ajuda a promover essas formas de aportes. Para Jouannet (2012, p. 250) ${ }^{50}$ nossa era é caracterizada pelo triunfo do liberalismo econômico na forma específica do livre comércio, e o "comércio livre e não simplesmente a liberdade de comércio se tornou o centro do direito econômico contemporâneo".

O "livre comércio" se fundamenta na crença de que promove o desenvolvimento econômico. Os investimentos estrangeiros diretos são anunciados como forma de operacionalizar e de incrementar esse comércio.

Para o nosso tema, aqui se torna pertinente porque a visão geral sobre os investimentos estrangeiros diretos é que ao adotar um regime de proteção dos direitos de propriedade intelectual, um país estaria mais propício a receber esses investimentos, posto que os investidores teriam segurança quanto à proteção de suas patentes, marcas, desenhos industriais, etc, quando investindo na produção de bens nesses países. Esta, por exemplo, é a visão externada por Kapoor e Tewari (2010) em artigo publicado pelo Ipea. Para estes autores, a China teria passado a receber mais investimentos estrangeiros diretos (em 2008 foi o terceiro país que mais recebeu esses investimentos ${ }^{51}$ ) na medida em que

\footnotetext{
${ }^{50}$ Em tradução nossa. No original da publicação: "free trade and not simple freedom of trade became the core of contemporary economic law".

${ }^{51}$ Os investimentos estrangeiros diretos na China desde então 2008, cresceu de maneira consistente até 2013 quando atingiu 290,23 bilhões de dólares norte-americanos, quando então iniciou uma queda
} 
eliminou restrições a estes tipos de investimentos na área de serviços e melhorou a proteção de direitos de propriedade intelectual.

No entanto há os que vêm esses investimentos, quando direcionados a países em desenvolvimento, como uma roupagem nova do velho colonialismo. Observa-se que o quadro de trocas de mercadorias do comércio internacional hoje não é muito diferente da época dos imperialismos, com determinados países exportando bens manufaturados caros e outra grande maioria exportando produtos primários.

Anne Mirjan Schneuwly (2012) afirma que:

"Historicamente, os investimentos estrangeiros diretos era uma consequência do colonialismo, um corolário necessário para a apropriação natural dos recursos pelas potências coloniais das suas colônias na África, Ásia e América do Sul. Para fornecer matéria prima para a industrialização de suas próprias economias, os colonizadores ocidentais precisavam dotar suas colônias da infraestrutura necessária para facilitar a extração" (SCHNEUWLY, 2012, p. 5).

Nesta época os poderes das potências com estes investimentos eram quase soberanos sobre o espaço onde se erguiam as infraestruturas, constituindo-se praticamente em áreas de "enclave". Em seguida, no pós-colonialismo se segue a formas de contratos conhecidos como "concessões", mas que não deixavam de ser altamente abusivas e exploradoras $(2012$, p. 6). Atualmente se constituem em "parcerias", mas são numerosas as críticas que, ainda que mudadas os enquadramentos jurídicos dos investimentos, os investimentos estrangeiros diretos, além de promoverem ganhos apenas ao setor privado, continuam desequilibrados e rendendo benefícios apenas marginais ao país receptor.

Para muitos autores há uma relação direta entre investimentos estrangeiros diretos e propriedade intelectual, uma vez que no investimento ocorre transferência de tecnologia. Em estudo para a Unctad, Dhar e Joseph (2012) afirmam que a transferência de tecnologia, como uma aquisição de conhecimentos pelas partes contratantes, sendo elas posteriormente capazes de implementar esses conhecimentos no processo produtivo, pode ocorrer com mecanismos com fundamento no mercado e sem fundamento no mercado. Com base no mercado estariam as trocas de bens e serviços, investimentos

atingindo 155,82 bilhões de dólares norte-americanos em 2019. Disponível em: https://www.macrotrends.net/countries/CHN/china/foreign-direct-investment. Acesso em 21/12/2020. Por outro lado os investimentos chineses diretos nos Estados Unidos também verificaram crescimento. 
estrangeiros diretos, licenças, joint-ventures e movimento de trabalhadores especializados através das fronteiras. Já a transferência de tecnologia sem fundamento no mercado seriam as imitações, saída de trabalhadores e informações sobre aplicações de patentes e testes.

Mas Dhar e Joseph (2012) ressaltam que os investimentos estrangeiros diretos são a forma mais significativa de transferência de tecnologia. Para os autores indianos os IED’s são mais geralmente vistos como fonte de tecnologia do que fonte de recursos financeiros, porque estes podem ser obtidos de outras fontes. Asseveram que é importante lembrar que uma empresa, em particular a multinacional, "pode (i) exportar diretamente o produto, (ii) produzir localmente com os investimentos e controlando o processo produtivo, (iii) licenciar ou franquear sua tecnologia para uma empresa local e (iv) fazer uma joint-venture envolvendo produção conjunta e compartilhamento de tecnologia" (DHAR e JOSEPH, 2012, p. 7). Essas alternativas dependem das características das vantagens e desvantagens locais, como infraestrutura, regulação, matéria prima, impostos e a proteção que a propriedade intelectual recebe naquele país.

Dhar e Joseph (2012, p.7) relatam estudos de 1992 que mostram que as exportações são menores para países que têm menores níveis de proteção da propriedade intelectual e que na realização de investimentos estrangeiros diretos para bens mais sofisticados as empresas se certificam que suas vantagens não sejam minadas. A empresa multinacional se beneficia dos conhecimentos produzidos em muitas fábricas de países diferentes, enquanto as empresas locais não têm essa facilidade. A relação entre propriedade intelectual e investimentos estrangeiros diretos deve, portanto, segundo ainda os autores, ser objeto de uma análise cuidadosa. Dhar e Joseph (2012, p. 8) afirmam que a relação também "é influenciada pelo tamanho do mercado", e que os investimentos podem depender da base científica e tecnológica do país hospedeiro. O segmento industrial também acaba influenciando sobre o conteúdo dos contratos de transferência de tecnologia. Os autores ressaltam que no campo farmacêutico e químico, sem a proteção da patente, $65 \%$ e $30 \%$ respectivamente das inovações não teria sido possível segundo estudos de Mansfield ${ }^{52}$.

A Índia é um país, ao lado da China, comumente tomado como exemplo, como país que tem uma política industrial para suas empresas em que os investimentos estrangeiros diretos ocupam uma parte importante. A Índia estabelecia limites de

${ }^{52}$ Os autores fazem referência ao estudo de Mansfield: Mansfield, Edwin (1985). How Rapidly Does Industrial Technology Leak Out ? Journal of Industrial Economics. Vol. 34, p.217-223. 
transferência (pagamentos) de royalties das empresas indianas para uma empresa estrangeira a título de licenças sobre direitos de propriedade intelectual, exceto marcas (limite máximo de 2 milhões ou 5\% das vendas domésticas ou 8\% das exportações da empresa). Em 2009, o governo retirou os limites máximos com o objetivo de atrair os investimentos estrangeiros diretos. O Departamento de Política e Promoção Industrial observou entre 2009 e 2010 uma transferência de royalties de 13\% dos FDI, e entre 2012 e 2013 18\% dos FDI. Entendeu o Departamento que a abertura não resultou em benefícios mensuráveis e estuda o estabelecimento de limites novamente ${ }^{53}$.

Tema curioso aparece quando observamos o Japão tanto em suas políticas industriais como também na sua política educacional voltada para os intercâmbios de estudantes e pesquisadores que patrocina. Quando suas instituições de estado concedem bolsas de pesquisa, estabelecem como compromissos contratuais a proteção da Propriedade Intelectual como item "necessário". Este cuidado teria o objetivo de promoção dos Investimentos Estrangeiros Diretos e para a Transferência de Tecnologia ${ }^{54}$.

A China, como se destaca em capítulo próprio, é o país de maior crescimento hoje no registro de propriedades intelectuais, notadamente das marcas e das patentes. Por isso nossa análise deste capítulo uma vez que os investimentos estrangeiros são apontados como importante fator para esse crescimento. Ao dissertar sobre a prosperidade econômica chinesa a partir dos anos 1990, Shu Sheng (2012) destaca que:

\begin{abstract}
"Em outro setor, mais um surto fantástico de crescimento: os investimentos de capitais estrangeiros. Ao longo das duas últimas décadas do século passado, a China converteu-se no grande mercado do mundo globalizado. Portos livres, zonas econômicas especiais, zonas econômicas abertas, zonas de desenvolvimento econômico, modalidades diferentes, todas visando criar as melhores condições para atrair capitais, incorporar tecnologia, exportar" (SHEN, 2012, p. 180).
\end{abstract}

Nesse ponto a visão de Shu Sheng coincide com a de Samuel Huntington (2010). Huntington afirmava em meados dos anos 1990 que a China estava se tornando um grande centro econômico asiático no que chamou de "esfera de coprosperidade chinesa", baseada em relações pessoais, de etnia e cultura comuns, de homens e empresas baseadas no entorno da China, como Cingapura, Hong-Kong, que ainda se readaptava ao

\footnotetext{
${ }^{53} \mathrm{http}: / / w w w . i a m-m e d i a . c o m / r e p o r t s / D e t a i l . a s p x ? g=f 07 c 348 \mathrm{e}-1462-4 \mathrm{~d} 72-\mathrm{a} 046-5 \mathrm{ecc} 4 \mathrm{a} 21 \mathrm{fde} 5$

54 Disponível em: http://www.jica.go.jp/brazil/portuguese/office/courses/c8h0vm00009v1mhkatt/J1604331_-

_Improved_Intellectual_Property_System_for_Promoting_Direct_Investiment_from_Overseas.pdf).

Acesso em 15.07.16
} 
país, Taiwan e outros países do Sudeste Asiático, como Indonésia e Malásia. Segundo Huntington chineses baseados nesses lugares tinham facilidades de investir na China e o fizeram com muita eficiência:

"Em 1992, 80 por cento dos investimentos estrangeiros diretos na China (11,3 bilhões de dólares) vieram de chineses de ultramar, sobretudo de Hong Kong (68,3 por cento), mas também de Taiwan (9,3 por cento), Cingapura, Macau e outras áreas. Em contraste, o Japão participou em 6,6 por cento e os Estados Unidos em 4,6 por cento do total. Do total dos investimentos estrangeiros acumulados de 50 bilhões de dólares, 67 por cento vieram de fontes chinesas" (HUNTINGTON, 2010, p. 285).

De fato, os investimentos estrangeiros diretos foram autorizados em 1979, e em 1980 foram criadas quatro zonas econômicas especiais na região costeira para receber esses investimentos, para onde foram 85\% desses investimentos. Ao final dos anos 1990, foram levados também para províncias no interior (LEMOINE, 2009, p. 276).

Por outro lado, Elias Jabbour entende que o papel dos investimentos estrangeiros diretos no desenvolvimento da China tem sido sobrevalorizado. Elaborando tabelas dos investimentos estrangeiros realizados na China entre os anos de 2004 a 2008 Jabbour (2010, p. 216) mostra que esses investimentos não foram tão numerosos proporcionalmente ao tamanho da economia chinesa. $\mathrm{O}$ autor destaca que os investimentos estrangeiros estavam ajustados a um projeto nacional em que outros fatores como a taxa de câmbio tiveram um papel maior. Ressalta ainda que boa parte desses investimentos vieram de países que o autor chama de "países satélites" como Hong Kong, Formosa (Taiwan), Cingapura, lembrando que muitos empresários chineses gerenciam seus negócios a partir da base administrativa de Hong Kong.

No mesmo sentido entende Lemoine (2009, p. 277) para quem, apontando ter sido a China, aparentemente, o terceiro país a mais receber esses investimentos entre 1992 e 2005, depois de Estados Unidos e Reino Unido, os investimentos estrangeiros na China são superestimados. A autora afirma que os valores são maiores do que os países parceiros declararam, mas nos números estatísticos se incluem capitais oriundos da própria China, mas que passaram por Hong Kong para serem reinvestidos "beneficiando-se do tratamento privilegiado concedido aos investimentos estrangeiros" (LEMOINE, 2009, p. 277). Esses valores podem representar até um quarto do total e "Com a reserva dessas incertezas, de 1990 até 2003, os investimentos estrangeiros na China vieram, essencialmente, dos países asiáticos $(70 \%)$ e metade desse total apenas de Hong Kong" (LEMOINE, 2009, p. 277). 
Nos últimos 30 anos, em especial a partir dos anos 1990, os Investimentos Estrangeiros Diretos estiveram relacionados com a fragmentação da produção. De acordo com o relatório de $2020^{55}$ do Banco Mundial sobre o Comércio Internacional em época de Cadeia Global de Valor, os Investimentos Estrangeiros Diretos estão correlacionados com a "global value chain", ou cadeia de valor global:

\begin{abstract}
"Muitas dessas cadeias de valor são gerenciadas e controladas por empresas multinacionais que organizam sua produção em diferentes localidades. Em alguns casos, os produtos estão próximos de novos consumidores, então o custo do comércio cai (investimento por mercados). Em outros se trata de aproveitar custos mais baixos de fatores de produção (investimentos por eficiência). Os dois tipos de investimentos têm contribuído para a dispersão internacional da produção, mas a segunda tem sido especialmente importante para o crescimento das cadeias globais de valor, que é evidente pelo crescimento dos fluxos de investimentos estrangeiros diretos e das cadeias globais, em especial a partir dos anos 1990" (Banco Mundial, 2020, p. 33).
\end{abstract}

O mesmo relatório aponta que os "fluxos de investimentos estrangeiros diretos nos países do Sul e do Norte estão positivamente relacionados, sugerindo que a expansão dos investimentos estrangeiros em um mercado não se dá em detrimento de outro" (Banco Mundial, 2020, p. 33).

Piketty (2014, p. 74) afirma que pela teoria econômica clássica a livre circulação dos fluxos de capitais seria um pilar para a convergência dos países na redução progressiva das desigualdades. Porém, apresenta dois problemas para esse entendimento. Afirma que esse mecanismo não garante a convergência de renda por habitante em âmbito mundial. E que,

\begin{abstract}
"do ponto de vista histórico, o mecanismo da mobilidade de capital não parece ter sido o fator que permitiu a convergência entre os países, ou, ao menos, não o fator principal. Nenhuma das nações asiáticas que reduziram o atraso em relação aos países mais desenvolvidos, quer se trate do Japão, da Coréia e de Taiwan no passado ou da China hoje, se beneficiou de investimentos estrangeiros substanciais" (PIKETTY, 2014 , p. 75, grifo nosso).
\end{abstract}

Responsáveis ou não por boa parte do crescimento econômico da China e de seu desenvolvimento tecnológico, talvez devêssemos olhar para os investimentos

\footnotetext{
55 No original: "Trading for Development. In The Age of Global Value Chain. "Disponível em: file:///C:/Users/eanda/Downloads/9781464814570.pdf. Acesso em 14/10/2020.
} 
estrangeiros diretos na China não tanto como causa, mas como consequência do próprio desenvolvimento chinês, uma vez que as políticas de desenvolvimento planejadas desde os anos 1970, com direcionamento e estratégia acabam por se tornar grandes atrativos para o capital produtivo estrangeiro. Um exemplo disso é a presença grande de marcas estrangeiras na China, inclusive em produtos tão simples como a água "mineral". Está a se tratar simplesmente de competir no mercado local, que no caso da China se mostra diversificado (quantidade de marcas, tabela 5). 


\section{Capítulo 10}

\section{A Geopolítica das patentes de telefones celulares}

O aparelho de telefonia celular se tornou o objeto técnico ícone de nosso tempo. O tal do "smartphone", ou telefone inteligente se tornou a nossa agenda, nosso despertador, o catálogo de nossos contatos pessoais, o meio de comunicação mais rápido, para além da comunicação entre duas pessoas, o celular, por diversos aplicativos (Whatsapp, Facetime, Skype, Zoom, Wechat, etc) permite a reunião virtual por vídeo conferência com número grande de participantes, é o aparelho informativo das notícias em tempo real, a bússola com geolocalização.

O aparelho celular, com esta multiplicidade de possibilidades, é ele próprio um equipamento móvel, de tamanho diminuto, que pode ser levado no bolso das pessoas, ao contrário do computador pessoal, que já havia sido um avanço na aceleração do tempo. Antes do advento do telefone celular, Doreen Massey (2000; p. 177) afirmou que "Vivemos em uma época - costuma-se dizer - em que as coisas estão se acelerando e se disseminando". Falando de uma nova fase de internacionalização, em especial do financeiro, Massey (2000) ressalta que o fenômeno havia sido denominado de “compressão de tempo-espaço", lembrando o que Marx havia denominado de "a aniquilação do espaço pelo tempo". Massey (2000, p. 177) assevera que a aceitação da ocorrência desses fenômenos leva ao uso quase obrigatório de expressões como “ 'aceleração', 'aldeia global', 'superação de barreiras espaciais', 'ruptura dos horizontes', e assim por diante”. Massey passa então a buscar o sentido que o local, e lugar podem vir a ter nesse novo mundo, nesse novo tempo. Busca refletir sobre as especificidades e o que é próprio do lugar, ressaltando que esses fenômenos chegam em tempo e modos diferenciados conforme a condição econômica e social dos lugares, sempre em detrimento dos menos favorecidos.

O aparelho de telefonia celular veio reforçar essa aceleração do tempo, e é um equipamento que chegou a um número enorme de pessoas em todas as partes do mundo, inclusive junto às populações mais marginalizadas em curto espaço de tempo. Estima-se que existam, em 2019, 5 bilhões de usuários de aparelhos celulares, ou $67 \%$ da população mundial e 3,6 bilhões com acesso à internet pelo telefone celular, ou seja praticamente a metade da população mundial (VALENTE, 2019). Uma tecnologia que chegou, portanto, a um grande número de pessoas no mundo, em tempo impressionante. 
Em análise comparativa se observou o tempo que novas tecnologias levaram para chegar ao patamar de 50 milhões de usuários. As companhias aéreas levaram 68 anos para atingir essa quantidade de usuários. A indústria automobilística levou 62 anos, o telefone fixo, 50 anos, os aparelhos de televisão levaram 22 anos. O telefone celular levou 12 anos e a internet 7 anos para alcançar os 50 milhões de usuários (GEROMEL, 2019, p. 75). Seu impacto nas relações sociais e na conexão dos lugares é assim inquestionável.

HAN (2018) falando sobre a era digital (que vai encontrar no telefone celular o seu ápice) afirma que se trata de uma grande mudança de paradigma. Citando McLuhan e o despreparo das pessoas com a rápida ascensão da técnica da eletricidade em contraposição à técnica de Gutenberg, diz que:

"Algo semelhante ocorre com a mídia digital. Somos desprogramados por meio dessa nova mídia, sem que possamos compreender inteiramente essa mudança radical de paradigma. Arrastamo-nos atrás da mídia digital, que, aquém da decisão consciente, transforma decisivamente nosso comportamento, nossa percepção, nossa sensação, nosso pensamento, nossa vida em conjunto" (HAN, 2018, p. 10).

Esta tese pode ser editada, revisada e encaminhada ao departamento acadêmico competente por este mesmo telefone celular. Está assim onipresente em nosso cotidiano, nos ajudando e orientando a nossa vida. $\mathrm{O}$ aparelho celular aproxima os lugares, realiza uma integração dos espaços, ainda que de forma diferenciada e acentuado desigualdades, avançando ainda mais em relação ao computador pessoal, que já representou uma magia e um avanço extraordinário. Acreditamos ser hoje o mais importante dos objetos em um sistema, que na conceituação de Milton Santos (1997) é denominado de sistema de objetos, e o que nos leva, neste capítulo a circunscrever a questão das patentes ao telefone celular.

O aparelho de celular inteligente (smartphone) como produto integrante do sistema de objetos, que demanda a aquisição de em torno de 2 mil patentes para ser fabricado, por partes em diversos lugares do planeta, é também um dos principais, senão o principal, instrumento de nossas ações, de orientação e deslocamento, sendo assim instrumento do sistema de ações, constituindo-se, a nosso ver, no principal mediador entre as duas esferas conceituadas por Milton Santos (1997). Santos (1997) afirma que "Os sistemas de objetos não funcionam e não tem realidade filosófica, isto é, não nos permitem conhecimentos, se os vemos separados dos sistemas de ações. Os sistemas de ações também não se dão sem os sistemas de objetos" (SANTOS, 1997, p. 90) 
Parece-nos também que é o objeto que melhor faz a mediação entre dois conceitos igualmente elaborados por Milton (SANTOS, 1997) que é o da tecnoesfera e psicoesfera, que juntos formam o meio técnico-científico, muito embora Milton não tenha, em vida, conhecido o smartphone em sua configuração atual de conexão à internet. Para Milton (SANTOS, 1997, p.14), a tecnoesfera "é o resultado da crescente artificialização do meio ambiente. A esfera natural é crescentemente substituída por uma esfera técnica, na cidade e no campo". Já a psicoesfera "é o resultado das crenças, desejos, vontades e hábitos que inspiram comportamentos filosóficos e práticos, as relações interpessoais e a comunhão com o Universo”. (SANTOS, 1997, p. 14).

Ainda na mesma obra, em seguida, Santos afirma “Ambos são frutos do artifício e desse modo subordinados à lei dos que impõem as mudanças". Possuir hoje um aparelho de telefone celular se mostra imperativo para se viver ajustado ao tempo, ao meio técnico-científico, "muito mais presente como psicoesfera que como tecnoesfera" (SANTOS, 1997, p 14).

E aqui se impõe um desafio à reflexão, de se pensar no aparelho de telefone celular conectado à internet, hoje alcançando milhões de pessoas em todos os lugares, com uma publicidade e uma massa de comunicação cada vez mais homogênea originada de poucos atores influentes. Sendo a tecnoesfera o mundo dos objetos e a psicoesfera o mundo das ações, Santos (1999, p. 17) afirma que a globalização é um processo incompleto e que os lugares "se definem pela sua densidade técnica, pela sua densidade informacional, pela sua densidade comunicacional" diferenciando os lugares. E "as relações técnicas e informacionais não podem ser 'indiferentes' ao meio social ambiente (SANTOS, 1999, p. 17). Temos, pois, uma disjunção entre uma crescente comunicação oriunda de um centro de poder (facebook, instagram, redes sociais em geral e sua publicidade inteligente), e toda a gama de informações obtidas via celular, externa, e a realidade empírica de cada localidade, aparentemente homogênea, mas profundamente desigual.

O "smartphone" nos parece, não apenas o objeto ícone de nosso tempo, mas um objeto de funcionalidades com profundo impacto na esfera da ação dos homens, naquilo que Milton denomina de psicoesfera. A centralidade desse objeto técnico é óbvia. E não por outra razão a competição entre as empresas que exploram essa mercadoria invariavelmente chegam aos tribunais. E o grande passo para que o telefone celular ganhasse essa centralidade se deve exatamente a este fato de ser conectado a toda uma rede (a rede mundial de computadores, www [world wide web] e aplicativos de 
comunicação simultânea, como o whatsapp, telegrama, etc) que é o foco maior de toda a concorrência e competição das grandes empresas na busca da dianteira tecnológica.

Essa conexão é possível pela tecnologia conhecida como "sistema operacional" desenvolvida no Vale do Silício e se resume a praticamente dois sistemas desenvolvidos por duas empresas somente. O primeiro sistema operacional que permite essa conexão é o iOS, desenvolvido pela empresa Apple, um sistema com código fechado. Apenas usuários adquirentes dos produtos Apple podem utilizá-lo, já que protegido como propriedade intelectual. O segundo sistema existente foi o desenvolvido pelo Google, denominado de Android. Os dois sistemas foram desenvolvidos praticamente na mesma época, entre 2005 e 2007. O telefone inteligente da Apple foi lançado em junho de 2007. O Google comprou a empresa Android em agosto de 2005 e passou a desenvolver o sistema de código aberto, que passou a ser usado por empresas como Motorola, Nokia e Samsung (Schmidt e Rosenberg, 2015, p. 224). Neste momento começaram as batalhas entre as duas empresas, que se estendem até hoje. Ao buscar os litígios instalados na Corte Federal do Norte da California encontramos quase uma centena de casos envolvendo a Apple e a Samsung, relativos a acusações de infrações de propriedade intelectual, a maior parte delas envolvendo acusações de copiar patentes ${ }^{56}$.

A quantidade de patentes de invenção que se encontra no telefone celular nos dá uma ideia da quantidade de tecnologias que se encontram neste pequeno aparelho. É um objeto técnico na conceituação clássica de Milton Santos, e é um dos elementos que mais influenciam o nosso agir, que mais traduz nossas vontades (vontades da distinção não apenas pelo aparelho em si, mas também pelas ações que ele possibilita, como as fotos de ostentação levadas às redes sociais digitais, direcionamento de geolocalização na condução de veículos, e pedidos de compras e ajudas emergenciais). É o objeto técnico que nos fundamenta, portanto, em nossas ações diárias da psicosfera.

O desenvolvimento desses aparelhos hoje se encontra em alguns países centrais da economia, Estados Unidos, China (assim já a consideramos) e Coréia do Sul. Parte da produção de partes dos aparelhos ocorre, de forma fragmentada, em alguns outros, como Índia, Vietnã, Emirados Árabes e mesmo o Brasil, mas sobretudo na China. Embora existam diversos fabricantes que juntos vendam bastante, o domínio tem se estabelecido cada vez mais, praticamente, com cinco empresas: a Apple, americana, a Samsung, sul coreana, a Huawei, a Xiaomi e a Oppo estas três últimas chinesas. Em 2017

\footnotetext{
${ }^{56}$ Disponível em: https://www.cand.uscourts.gov/search_gcse/?q=Samsung. Acesso em 04/10/2020.
} 
se observa um quadro de queda da participação das demais empresas (Tabela 4) e variação das cinco empresas.

Tabela 7: Participação de mercado das empresas de telefonia celular

\begin{tabular}{l|l|l|l}
\hline & 2018 & 2019 & $\begin{array}{l}2020-\text { até } 2^{\circ} \\
\text { quadrimestre }\end{array}$ \\
\hline Outras Marcas & 32,0 & 28,9 & 27,8 \\
\hline Huawei & 16,2 & 15,2 & 20,2 \\
\hline Samsung & 18,8 & 18,8 & 19,5 \\
\hline Apple & 18,3 & 19,9 & 13,6 \\
\hline Xiaomi & 7,9 & 8,9 & 10,3 \\
\hline Oppo & 7,9 & 8,3 & 8,7 \\
\hline
\end{tabular}

Fonte: IDC. Disponível em https://www.idc.com/promo/smartphone-marketshare/vendor. Acesso em 06/10/2020

Observa-se que juntas, as marcas chinesas (Huawei, Xiaomi e Oppo) possuem 39,2 \% do mercado de telefones móveis celulares, todas com crescimento no percentual de participação nos últimos três anos. Mais que as concorrentes Apple americana e a Samsung sul coreana juntas, sendo que a sul coreana também apresenta crescimento e o declínio da Apple no último ano foi considerável.

Mariana Mazzucato (2014) destaca o papel do Estado americano no crescimento da Apple, empresa que inovou na área dos celulares, após 30 anos (19772007) se dedicando aos computadores pessoais, retirando inclusive o termo "computers" do nome empresarial. A adoção da tecnologia desenvolvida pelas forças armadas e os subsídios estatais foram fundamentais para o desenvolvimento do celular da Apple.

A Apple tomou a dianteira na corrida do celular inicialmente, mas era uma tecnologia ambicionada por todas as demais empresas de tecnologia, como a Microsoft, conforme confessa Paul Allen, cofundador com Bill Gates, em sua autobiografia:

\footnotetext{
"Muitos jovens gastam a metade ou mais de seu tempo em computação com seus telefones celulares. Conforme os visores dos celulares melhoram e sua banda de conexão se expande, o momento dos celulares só acelera. A Microsoft não estava cega a esta tendência. Ela lançou seu primeiro sistema operacional para celulares em 2000, mas os primeiros aparelhos da companhia falharam quando saíram para o mercado. Então o i-Phone rompeu com um sedutor 'touch screen' e uma interface
} 
amigável, e a Microsoft acabou por perder um ciclo inteiro na tecnologia do consumidor" ${ }^{\circ 7}$ (ALLEN, 2011. p. 186).

Ainda para Allen (2011, p. 186) a Apple e o Google venceram a Microsoft nesta corrida em que "Os robustos iPhones e Droids são os produtos de comunicação de alta velocidade, fabricação de baixo custo e microprocessadores super rápidos".

A Nokia, empresa finlandesa, fundada em 1865, com sede em Espoo, foi líder no mercado de telefones celulares nos anos 1990 (portanto antes do celular inteligente = smartphone). Agora parece estar resignada com a perda da liderança e foca na produção de equipamentos de telecomunicações como torres de telefonia móvel, comutadores telefônicos, roteadores de internet e novos componentes para a tecnologia 5G. Neste mercado está em segundo lugar (com $17 \%$ do mercado) atrás da chinesa Huawei $(28,6 \%)$ e à frente da Ericsson $(13,4 \%)^{58}$.

Desde o início de sua concepção, portanto, o telefone celular é uma tecnologia que desperta competição acirrada entre as empresas de tecnologia. E as chinesas, avançam neste mercado ano a ano.

Mas a corrida é contínua, e mesmo a Apple pode estar a perder a dianteira. $\mathrm{O}$ Jornal Folha de São Paulo de 04/01/19, reproduzindo matéria do Financial Times (tradução de Paulo Migliacci - pg A18), aponta que "Consumidor chinês perde entusiasmo com iPhone". A matéria relata que há dez anos os jovens consumidores chineses, ávidos pelas novidades, formavam longas filas na abertura da primeira loja da Apple em Pequim em 2008. Símbolo de status e de luxo, os jovens estão deixando a lealdade à Apple e se aproximando cada vez mais da Huawei, que avançou bastante tecnologicamente.

A Apple fez o lançamento de seu aparelho celular habilitada para a tecnologia 5G apenas em outubro de 2020, um ano depois da Huawei e da Samsung. O território americano está também com atraso se comparada à China, onde as principais cidades já

\footnotetext{
57 Tradução livre do autor. No original: Many younger people already spend half their computing time and more on their smartphone and slates. As the phone's displays improve and their network bandwidth expands, mobile's momentum will only accelerate. Microsoft wasn't blind to this trend. It released its first mobile operating system back in 2000, but the company's early, stylus-driven devices fell flat in the marketplace. Then the iPhone broke through with a seductive touch screen and friendly interface, and Microsoft wound up missing na entire cycle in consumer technology.

${ }^{58}$ Dados de 2019 da Dell’Oro Group. Versão impressa da Folha de São Paulo. 03/06/2019. Página A24. Disponível em: https://www1.folha.uol.com.br/tec/2019/06/lider-em-celular-nos-anos-1990-nokia-agorabusca-desbancar-huawei-em-5g.shtml. Acesso em 20/12/2020.
} 
contam com coberturas da tecnologia e na Coréia do Sul $90 \%$ da população vive em áreas de cobertura ${ }^{59}$.

O aparelho de telefonia celular móvel que já em si um avanço imenso em relação ao telefone fixo, pois permite a comunicação imediata de praticamente qualquer coordenada geográfica que o usuário esteja, seja recebendo ou emitindo a chamada, e que ainda contém diversas tecnologias que são passíveis de uso imediato pelas ondas e antenas, passa a um estágio de ainda maior avanço ao permitir que através dele seja acessada a rede mundial de computadores, a internet. Por este acesso o usuário tem acesso imediato às bilhões de informações colocadas na rede mundial a todo momento, que se constitui em um banco de dados praticamente inesgotável.

Nesta tecnologia da internet os norte-americanos deram um passo gigantesco em seu início. Tendo sido desenvolvido pelas Forças Armadas dos Estados Unidos em 1969 um sistema então denominado de "Arpanet" para que as informações sigilosas e estratégicas fossem mantidas em rede e não apenas em uma central, que poderia ser objeto de um ataque, se constituiu, já como internet, na tecnologia definidora dos avanços da sociedade da informação no início do Século XXI. Os criadores que a transformaram de uma tecnologia privativa das Formas Armadas para uma tecnologia de uso público e comum trabalharam e criaram códigos abertos para que fosse acessível a todos. E assim é até hoje, em grande medida preservada pelos comitês gestores da internet dos países, que são encarregados pelos protocolos de acesso e dos registros dos domínios na rede (construção de sites com endereçamento definido). Esses comitês são compostos por representantes de governos, universidades, da iniciativa privada e da sociedade civil, com ampla participação.

Mas em que pese a relativa democracia participativa, em que os comitês gestores da internet nos países são compostos por representantes de governo, iniciativa privada, universidades e entidades do terceiro setor, as tecnologias de acesso e dos equipamentos que permitem este acesso ainda são dominadas pelas grandes empresas de tecnologia.

Bill Gates, fundador da Microsoft, empresa pioneira desse novo período técnico, já previa isso. Em memorando escrito aos gestores de sua empresa, em 26 de maio de 1995, que veio à tona por ocasião da ação promovida pela Promotoria americana

\footnotetext{
${ }^{59}$ Disponível em: https://www1.folha.uol.com.br/tec/2020/10/apple-lanca-iphone-12-em-quatro-modeloscom-5g-preco-inicial-e-de-us-699.shtml. Acesso em 14/12/2020. Na versão impressa de 14/10/2020. Página A23 da Folha de São Paulo.
} 
contra a empresa sob a alegação de constituição de monopólio em 2006, Gates (2006, p.1) assevera que os últimos vinte anos (portanto de 1975 a 1995) se viu o aprimoramento exponencial das capacidades computacionais e que nos próximos vinte anos (portanto seria de 1995 a 2015) a melhora no poder computacional seria baseado no aprimoramento exponencial das redes de comunicação. E sobre a internet afirmava que: “A internet está na vanguarda de tudo isso e o desenvolvimento da internet nos próximos anos irá determinar o curso de nossa indústria por muito tempo no futuro".

E, de fato, o desenvolvimento da internet e sua possibilidade de acesso pela telefonia celular se constitui em um dos ápices da revolução tecnológica que estamos a vivenciar e que explica a imensa corrida e a guerra das empresas nos tribunais mundiais.

$\mathrm{O}$ telefone celular inteligente é o instrumento de acesso mais rápido à rede mundial de computadores, a internet (e neste ano de 2020 mais da metade dos usuários da internet o fazem via telefone celular ${ }^{60}$ ), que com a conexão em alta qualidade (a tecnologia conhecida como $5 \mathrm{G}$, também como a internet das coisas, porque todos os equipamentos do cotidiano, como televisão, geladeira, relógio, carros e transporte público estarão conectados) e a inteligência artificial (constituída de algoritmos que nos indicam o caminho mais curto) se constituem no instrumento mais importante do poder político e econômico e na forma superior de extração, a mais valia de que falam Hardt e Negri (2018), conforme nossa explanação no capítulo das marcas:

Outra face da extração toma a forma de dados. As metáforas de 'mineração de dados' e 'extração de dados' sugerem a imagem de campos não estruturados de dados sociais, disponíveis, assim, como o petróleo ou outros minerais da terra [....] Minerar e extrair dados significa capturar valor mediante a busca por padrões em grandes massas de dados e a estruturação de dados visando seu armazenamento e venda. [....] As mídias sociais também descobriram mecanismos para extrair valor das relações sociais e conexões entre os usuários. Por trás do valor dos dados, em outras palavras, está a riqueza das relações, inteligência e produção sociais" (HARDT; NEGRI, 2018, p. 228).

Os dados se acumulam e são extraídos por todos os acessos à internet, como computadores pessoais e tablets, mas é sobretudo no celular que se dá essa captura maior

\footnotetext{
${ }^{60}$ Segundo o Centro de Pesquisa da Publicidade Mundial (World Advertising Research Center WARC) 2 bilhões de pessoas acessam a internet apenas de seus celulares, o que se constitui em 51\% dos usuários mundiais de telefones celulares. Esse percentual deverá atingir 3,7 bilhões de pessoas, ou 72,6\% dos usuários em 2025. Disponível em: https://www.cnbc.com/2019/01/24/smartphones-72percent-of-peoplewill-use-only-mobile-for-internet-by2025.html\#: : :text=WARC\%20estimates\%20that $\% 20$ around $\% 202$,base $\% 20$ of $\% 203.9 \% 20$ mobile\%20user s. Acesso em 06/10/2020.
} 
de dados porque se capta também a locomoção no território e os roteiros tradicionalmente realizados pelas pessoas. 
Em 1958 estabeleceram-se as comunas populares.

Os cinco mus de minha família foram coletivizados. Sobrou apenas o quintal em frente ao meu casebre para cultivo particular. Aquele a quem chamávamos de chefe da aldeia passou a ser, daquele momento em diante, o chefe da comuna.

E quem iria imaginar que algum tempo depois até a wok de casa se tornaria propriedade coletiva, sob o pretexto de ser derretida para fazer aço?

Peguei a wok e pus ali no chão. Dois jovens levantaram a enxada e começaram a quebrá-la. Com apenas quatro ou cinco enxadas, uma boa wok ficou esmagada. Jiazhen observava a cena tão aborrecida que chegou a derramar algumas

lágrimas. Ela perguntou ao chefe: - Como iremos cozinhar agora? - Comam no refeitório. - Abanando a mão, ele continuou: - Por causa do recolhimento das woks, foi organizado um refeitório na aldeia; ninguém mais precisa cozinhar em casa. Agora vocês podem concentrar todas as suas energias na construção do comunismo.

Yu Hua

Viver, (HUA, 2008) 


\title{
TERCEIRA PARTE
}

\section{A COMPETIÇÃO ENTRE ESTADOS UNIDOS E CHINA PELA LIDERANÇA DAS MARCAS E PATENTES}

Defendemos assim que os direitos de propriedade intelectual se constituem em mecanismos de proteção do conhecimento e desde a sua constituição em finais do Século XIX em nível internacional, apenas a Coréia do Sul e a China conseguiram romper o bloqueio e atingir uma economia dinâmica baseada no desenvolvimento tecnológico, seguindo, no tocante à este direito um caminho parecido ao de Inglaterra, Estados Unidos e países da Europa Ocidental que antes de adotar legislação rígida de propriedade intelectual praticaram ampla pirataria para aquisição de tecnologias. O Japão também o fez, reproduzindo e aprimorando tecnologias estrangeiras, mas já tinha uma base industrial significativa o bastante para que, com a ajuda financeira externa do PósSegunda Guerra, conseguisse atingir o centro dinâmico da economia.

O caso do desenvolvimento econômico e tecnológico da China, como veremos, vai além. Não nos resta dúvida que seja pelo tamanho da economia, pela rapidez do processo de desenvolvimento e pela intensidade de sua inovação tecnológica em todos os aspectos relevantes da atual fase técnica-científica-informacional, nos termos de Milton Santos (1997), estamos diante de um quadro apenas comparável com o desenvolvimento que os Estados Unidos vivenciaram a partir do final do Século XIX.

Para Elias Jabbour:

\begin{abstract}
"Intentamos fugir da superfície. A única razão desse gigantesco processo em andamento na China é observá-lo como parte da história da civilização humana; não se trata de um milagre, muito menos de um acaso. Munido com uma visão historicista e observando além do horizonte, é perceptível a ocorrência de um processo histórico onde uma nova economia mundial está surgindo, tendo na China seu núcleo de ocorrência sob o acicate do chamado 'socialismo de mercado'. Processo semelhante marcou o século XX com uma economia desenhada nos marcos do desenvolvimento do capital financeiro, o keynesianismo e a planificação soviética" (JABBOUR, 2020, p. 50).
\end{abstract}

Embora procuremos traçar paralelos entre o desenvolvimento dos Estados Unidos a partir da segunda metade do Século XIX e o desenvolvimento da China cem anos depois, às vezes de maneira explícita e outras implícita, para o caso de patentes dos 
Estados Unidos, impossível o seu uso como método comparativo direto para o período de ascensão americana, porque não havia ainda em meados do Século XIX legislação internacional sobre o tema das propriedade intelectuais e nem órgãos internacionais de registro, sendo impraticável tal método.

É bem verdade, por um lado, que a literatura apresenta números sobre o tema, como Huberman (1987, p. 169) que, ao discorrer sobre o período de industrialização e a febre de inovações, afirma que "O trabalho de todos esses inventores está claramente registrado nos arquivos do Escritório de Patentes. De 1850 a 1860 uma média de 2.370 patentes eram inscritas cada ano; de 1920 a 1930 esse número pulou para cerca de 44.750 por ano". Mas é também preciso, por outro lado, relativizar esses números porque a proteção e a fiscalização eram extremamente difíceis de serem efetivadas no âmbito efervescente da industrialização e da competição. Milligan (2004), por exemplo, afirma que a industrialização americana se deu em seu início via pirataria tecnológica, que é a mesma tese sustentada por Chang (2004).

Neste segundo período apontado por Huberman (1987), já no Século XX, quando a industrialização norte-americana já estava consolidada e o país já ultrapassava a Inglaterra, conforme podemos verificar das tabelas 11 e 12, é possível dizer que o registro de patentes americanas realmente cresceu bastante, uma vez que podemos verificar que no Brasil, empresas americanas foram as que mais registraram patentes entre 1882 e 1910, com 719 pedidos vindos dos Estados Unidos (MARINHO, 2017, p.15). São, contudo, dados esparsos, não sistematizados ano a ano, e em período em que não havia um tratado internacional com efetividade. O Acordo Trips de 1994 se propôs como acordo global, justificado pelas grandes potências como necessário porque os tratados internacionais anteriores não tinham efetividade de cumprimento (instrumentos hábeis de fiscalização) entre os países signatários.

Por esta razão, entre outras, é que tomamos índices de outros países, para comparações contemporâneas.

Sobre a Coréia do Sul, apenas o abordamos lateralmente, para focar na China, que é o fenômeno aqui estudado. Linsu Kim (2005) demonstra que em apenas trinta anos, a partir de 1961 a Coréia do Sul conseguiu passar de uma economia agrária de subsistência a uma economia industrializada e moderna. Em 1961 o Produto Interno Bruto (PIB) do país asiático era menor que do Sudão e em torno de $30 \%$ do PIB do México. Situação esta decorrente de uma série de tragédias entre 1945 e 1953. Embora anteriormente progredisse cientificamente no campo das ciências exatas quando se 
encontrava sob o domínio do Japão no início do século XX, com a saída do Japão após a derrota na $2^{\text {a }}$ Guerra Mundial, este levou embora a tecnologia e os técnicos, deixando um vazio industrial no país. Os sul coreanos, que tinham apenas funções na linha de produção, não sabiam operar máquinas e gerenciar fábricas. Em seguida, a divisão entre a Coréia do Sul e Coréia do Norte fez com que todas as matérias primas para as indústrias ficassem no norte enquanto as fábricas estavam situadas no sul. Finalmente a Guerra da Coréia entre 1950 e 1953 acabou por destruir as instalações e infraestrutura que ainda perduravam (KIM, 2005, p. 22).

Portanto, a partir desse quadro na década de cinquenta do século XX, é que a Coréia do Sul é vista como o mais notório caso de "catching up"61 da história recente. Na década de 1990 a Coréia do Sul já produzia tecnologia de ponta, possuía uma indústria automobilística, era grande exportadora de bens de alto valor agregado, detentora de marcas que começavam a ganhar o mundo, como a Hyundai, Samsung, Daewoo, LG e outras. Em 1995 a renda per capita ultrapassou os dez mil dólares americanos e se tornou a $11^{\mathrm{a}}$ maior economia do mundo em termos de produto interno bruto, passando a integrar o grupo dos países ricos (ANDAKU, 2016, p. 32).

Há quem veja a ajuda americana por questões estratégicas como fundamental no desenvolvimento sul-coreano. Linsu Kim (2005) fala em uma injeção de 6 bilhões de dólares americanos ao longo da década de 1960. Mas o autor afirma também que todo o esforço de construção de uma nova nação foi depositado na construção de uma nação industrializada, com um governo forte apoiando a formação de grandes conglomerados, denominados de chaerbols. E a Coréia do Sul iniciou sua industrialização pela a imitação de produtos estrangeiros, seja pela produção de produtos cujas patentes já tinham caído em domínio público ou por adaptações criativas, dentro da legalidade, portanto, seja pela técnica, proibida, da engenharia reversa:

Na Coréia, como em outros países em processo de catching-up, a imitação através da engenharia reversa de produtos estrangeiros existentes foi o principal suporte do processo de industrialização até meados da década de 1980. Até os países mais desenvolvidos continuam dependendo bastante da cópia de produtos estrangeiros, e $\underline{\mathrm{se}}$ recusam a respeitar as leis de propriedade intelectual até que desenvolvam capacidade de se tornarem auto-suficientes (KIM, 2005, p. 68 , grifo nosso).

\footnotetext{
${ }^{61} \mathrm{Na}$ economia, processo de desenvolvimento rápido para atingir o estado da técnica e o estágio de desenvolvimento dos países desenvolvidos.
} 
Em 1986, por pressão dos Estados Unidos, ainda segundo Linsu Kim, a Coréia do Sul foi obrigada a adotar uma lei de propriedade intelectual, que proibia, por exemplo, a engenharia reversa, mas que não era respeitada, pois na Ásia "as pessoas não aceitam que alguém seja proprietário de uma idea ou pensamento, e que se deva pagar por isso" (KIM, 2005, p. 69).

Segundo o Banco Mundial, a Coréia do Sul é um país de alta renda para os padrões da Organização para a Cooperação do Desenvolvimento Econômico (OCDE), com renda per capita em 2018 de 30 mil dólares norte-americanos (no início dos anos 1950 era de 67 dólares, e em 2012 de 22.670 dólares norte-americanos), uma expectativa de vida de 82,627 anos (para 2018), e um produto interno bruto de 1.642 trilhões de dólares americanos para $2018^{62}$.

E hoje o principal instrumento de coerção para coibir o desrespeito aos direitos de propriedade intelectual é o denominado acordo Trips (Acordo dos Aspectos da Propriedade Intelectual Relacionados ao Comércio, resultante da Rodada Uruguai que também criou a Organização Mundial do Comércio, em 1994, e que ainda suscita imensos debates entre os países, inclusive levando a grandes litígios envolvendo a propriedade intelectual.

Armén Mamigonian (1982) aponta que há concorrência também no centro dinâmico da economia capitalista. Ou seja, os países ricos também competem entre si levando a um desenvolvimento desigual dos países. Mamigonian (1982) analisa o período correspondente ao último quarto do século XX e assevera que "Pouca ênfase, entretanto, tem sido dada ao desenvolvimento econômico e tecnológico desigual que ocorre no centro do sistema, onde os Estados Unidos recuam e o Japão avança”. O autor mostra como o desenvolvimento tecnológico se encontrava, naquele momento, em estágios diferentes entre os Estados Unidos, países da Europa e o Japão, e que este último passava a dominar o mercado do aço e das memórias dos computadores.

Observa-se assim que os países ricos e suas empresas atuam em conjunto quando se faz necessário para enfrentar países que ameaçam essa hegemonia, como se vê pela análise dos tratados internacionais, notadamente o Acordo Trips, que implementou com prazo exíguo (dez anos) o cumprimento do tratado pelos países em desenvolvimento, como se nesse prazo fosse possível a estes atingir o nível tecnológico dos desenvolvidos.

\footnotetext{
${ }^{62}$ Dados obtidos no site do Banco Mundial: http://data.worldbank.org/country/korea-republic\#cp_wdi.
} 
Mamigonian (1982) demonstra que empresas americanas e europeias deixaram de fora as japonesas no momento de constituição dos cartéis. E que quando se trata de tomar a frente do processo de desenvolvimento, cada país toma para si as políticas públicas que julga as mais benéficas.

Para a compreensão do que estamos a viver hoje, imprescindível a compreensão do período do Pós-Segunda Guerra, conhecidos como os "Trinta Gloriosos". Benko e Dunford (1991, p. 1) afirmam que, "No curso dos anos 1950 e 1960, o crescimento econômico conheceu uma aceleração em relação às tendências anteriores que marcaram o desenvolvimento econômico do Século XX"63, e que nos anos 1960 e 1970 se percebe uma diferença setorial nas taxas de crescimento da produção e da produtividade, creditando o fato a mudanças nas tecnologias dos produtos e nas tecnologias de fabricação (BENKO E DUNFORD, 1991, p. 2).

Ainda para os autores, em seguida, a gravidade das recessões dos anos 1970 e 1980 levou os economistas a retomarem às teorias dos ciclos longos do capitalismo, como o já mencionado anteriormente o de Kondratieff. Benko e Dunford (1991, p.4) se voltam para a explicação Schumpeteriana e neo-Schumpeteriana das ondas longas, segundo as quais também (como as de Kondratieff) são marcadas por ciclos de 50 anos dentro dos quais há aceleração e desaceleração do crescimento econômico. Distinguindo três ondas de Kondratieff (revolução industrial - 1787-1842, onda burguesa ou das ferrovias 1843-1897 e a onda neo-mercantilista depois de 1898), os autores apontam que para Schumpeter o surgimento dessas ondas correspondeu a emergência e expansão rápida de novas indústrias em que os industriais transformaram as invenções em inovações. "As inovações permitem rendas de monopólio e suscitam imitações e melhoramentos $^{64 "}$ (BENKO E DUNFORD, 1991, p. 4).

Esta frase citada é importante para a fundamentação da presente tese. As inovações permitem rendas de monopólio exatamente pela instituição do direito de patente que permite ao inovador usar sozinho, em monopólio, (ou licenciar o uso mediante pagamento ou renda [royalties]) sua criação. E porque suscitam imitações e melhoramentos é que as legislações de direitos intelectuais se tornam mais rigorosas nesses períodos. Os primeiros Tratados Internacionais de Propriedade Intelectual se

\footnotetext{
${ }^{63}$ Tradução do autor. No original: "Au cours des années 1950 et 1960, la croissance économique connut une accélération par rapport aux tendances antérieures qui marquérent le développement économique du XXe siècle".

${ }^{64}$ Tradução do autor. No original: "Les innovations permettent des rentes de monopole et suscitent imitations et amélioration".
} 
encontram dentro do segundo momento apontado por Schumpeter, que muitos outros autores apontam como momento da Segunda Revolução Industrial (Convenção de Paris sobre a Propriedade Industrial de 1883 e a Convenção de Berna de Direitos Autorais de 1886).

Em seguida, ainda na visão Schumpeteriana, as inovações se difundem, cai o lucro e a confiança dos industriais, em um processo denominado de destruição criativa.

Pela leitura de índices econômicos e, sobretudo, dos índices das propriedades intelectuais, fica claro que, desde 2002, quando a China se tornou membro da Organização Mundial do Comércio, ela vem substituindo o Japão como segunda força mundial, e no caso de patentes ela alcançou em 2017 os Estados Unidos na primeira colocação no ranking de pedidos de registros de patentes industriais e em 2019 no ranking registro de patentes no tratado PCT, de patentes de validade internacional.

É importante destacar a importância das propriedades intelectuais no comércio internacional. As receitas oriundas da cobrança pelo uso de propriedades intelectuais (licenciamentos de marcas, patentes, direitos autorais, entre outros) tem um crescimento grande a partir de 1985 e se torna acentuado a partir de 2000, ultrapassando os 300 bilhões de dólares norte-americanos em 2015, conforme podemos ver da figura 4. Este também um motivo para se dedicar, nesta tese, às marcas e patentes como direitos fundamentais para a compreensão do jogo de poder econômico do mundo contemporâneo. 
Figura 3 - Receitas oriundas da cobrança de propriedades intelectuais

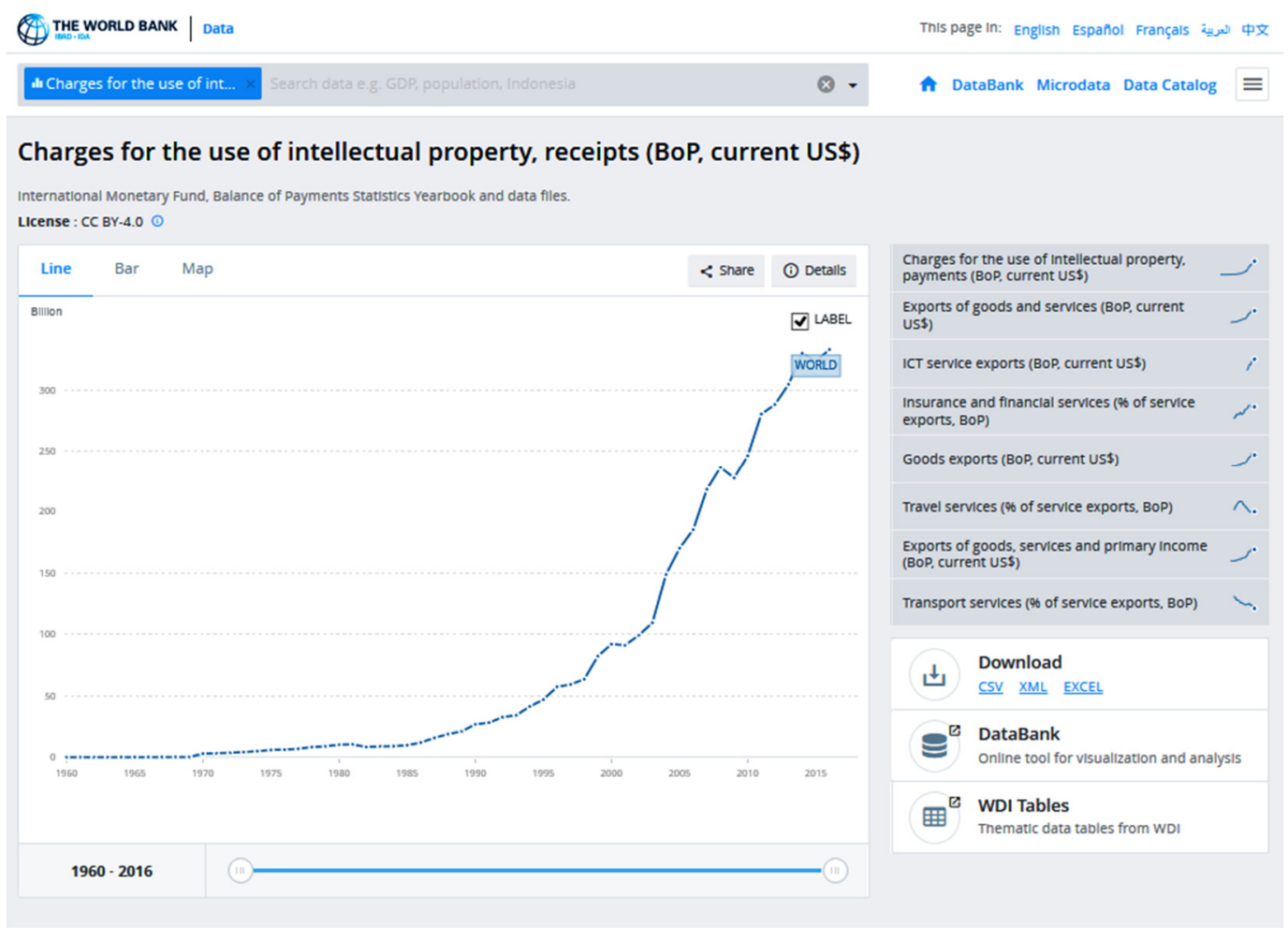

Fonte: Banco Mundial

Estamos a falar na presente tese, portanto, em um tema imaterial, que são os direitos de propriedade intelectual. Mas de forma alguma se pode dispensar a base material. Não há de se falar, por exemplo, em tecnologia de internet $5 \mathrm{G}$, conexão e inteligência artificial sem que lembremos que essa alta conectividade se dá mediante cabos de fibras óticas que passam pelo fundo do oceano e conectam países e continentes. Ricardo Castilho (2010, p. 462) coloca que "Uma das características mais marcantes do atual período encontra-se no exponencial aumento dos fluxos materiais e imateriais, decorrente da gradativa mundialização da produção, da prestação de serviços e do consumo, pelo menos para alguns setores e circuitos econômicos" e que a esfera material é formada em essência pela "expansão e a modernização do sistema de telecomunicações e de transportes". Por este motivo, analisamos também a expansão da infraestrutura chinesa e sua produção automotiva, que por seu potencial de desenvolvimento de outras tecnologias agregadas se constituiu num avanço fundamental no processo de desenvolvimento e inovação de todo o parque industrial da China. 


\section{Capítulo 11}

\section{A ascensão da China}

Quando falamos da ascensão chinesa estamos a falar não apenas de crescimento econômico (que é o aumento do produto interno bruto), mas também de desenvolvimento econômico, que está relacionado à melhoria do bem estar material da população. Embora índices de desenvolvimento social (renda per capita, educação, etc) ainda estejam aquém dos Estados Unidos, Europa e Japão, a China se aproxima do pleno desenvolvimento, devido, em nosso entendimento, principalmente pelo grande desenvolvimento científico e tecnológico.

Antes, porém, de adentrar análises empíricas desse desenvolvimento é preciso situá-las em seu contexto histórico, porque uma ascensão como a que observamos não acontece de uma hora para outra. É, como nos outros casos asiáticos de sucesso nos processos de catching up, resultado de um processo longo e amplamente planejado pelo Estado.

Lembrando que a China já fora outrora o centro de grandes avanços e invenções técnicas, durante a dinastia Song (960-1279), por exemplo, possuía a frota naval e tecnologia náutica mais avançada do mundo (Kissinger 2011 e Paul Kennedy, 1989), mas depois passando por alguns séculos de fechamento em relação ao Ocidente e descompasso com o estado da técnica ocidental, nos parece haver dois momentos cruciais recentes que parecem explicar a presente ascensão. No período de Mao-Tse' Tung, que antes mesmo de assumir o poder já exaltava em discursos as realizações científicas chinesas, houve uma grande preocupação no desenvolvimento da indústria pesada e na aquisição da tecnologia da produção do aço. Kissinger (2011) relata que na Conferência dos Partidos Socialistas em Moscou em 1957, à previsão de Khruschev de que a União Soviética ultrapassaria os Estados Unidos na economia em 15 anos, Mao afirmou que a China superaria a Grã-Bretanha na produção do aço e "Esse comentário não tardou a assumir o status de uma diretiva" (KISSINGER, 2011, p. 123), sendo parte do planejamento de desenvolvimento conhecido como o "Grande Salto". Destacamos esse período como primordial porque alinhamos à tese de Chang (2014) de que para inovar é preciso estar produzindo, de que não existe inovação meramente de laboratório, mas da experiência concreta da indústria. Nesse sentido o fomento e crescimento da indústria pesada foi fundamental. 
Um segundo momento importante nos parece ser durante a gestão de Deng Xiaoping, em uma ascensão ao poder gradual, Deng assume em 1978 lançando reformas de abertura econômica com a criação de zonas especiais, continuando com planejamento de fundamentos de crescimento econômico que se seguiu depois. Segundo Kissinger (2011, p. 209): “Em 26 de setembro de 1975, em comentários intitulados 'A prioridade deve ser dada à pesquisa científica', Deng tocou em diversos temas que seriam sua marca registrada: a necessidade de ênfase em ciência e tecnologia para o desenvolvimento da economia chinesa". Em dezembro de 1992 definiu o país como uma economia socialista de mercado.

Existem outros períodos apontados como importantes no processo de desenvolvimento, como a entrada da China na Organização Mundial do Comércio no início dos anos 2000, a partir dos quais, aliás, é possível analisar sua ascensão nas propriedades intelectuais. Para Jabbour (2019, p. 78) "O caso chinês é mais enigmático e rico, pois as reformas de 1978 marcam o início de um processo em que o desenvolvimento de um modo de produção distinto (socialismo) demandou que um novo tipo de superestrutura literalmente 'fabricasse' um mercado como forma de sua sociedade se revigorar". Ou seja, para o autor, a criação de um ambiente apropriado dirigido pela autoridade estatal também é um processo importante e que "A construção do mercado levou o país a uma completa reorganização de sua estrutura social. O mercado passou a ser instrumento de governo para revigorar sua base material" (JABBOUR, 2019, p. 78).

Para a compreensão desse desenvolvimento, Elias Jabbour (2019) revisita clássicos do desenvolvimento que nos permitem observar que o caso chinês é distinto de outros casos clássicos analisados por esses autores, e a partir dos quais podemos extrair que (Holz [2010] sobre Hirschman, p.190) a "China, no início das reformas econômicas em 1978, possuía uma base industrial equilibrada e o governo já estava fortemente envolvido na economia" e, a partir de Prebisch que em relação a China "Sua condição periférica é de natureza diversa em comparação à da América Latina” (JABBOUR, 2019, p. 192).

A ascensão da China como potência tecnológica é clara, principalmente quando adotamos os critérios dos pedidos de registro de patentes que é nosso foco neste trabalho. A patente não é o único critério de avaliação do desenvolvimento tecnológico de uma dada sociedade. É preciso destacar que muitas invenções da indústria não são 


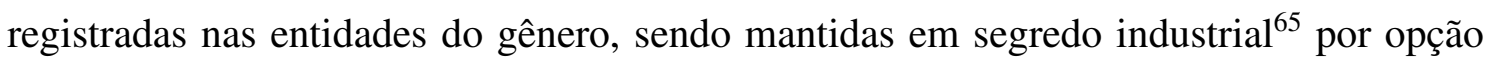
estratégica de empresas de certos ramos de atividade. Existem ainda muitas empresas que sequer têm a preocupação de patentear suas inovações, ou suas inovações não preenchem os requisitos mínimos de originalidade inventiva para serem registráveis, embora possam representar avanços efetivos para o setor industrial. No entanto, os registros de patentes se constituem em poderosos medidores do estado da técnica em uma determinada sociedade ou país. Tales Andreassi et al. (2000) por exemplo, fizeram um estudo levantando os prós e os contras de se utilizar as patentes como critério de medição do desenvolvimento. Chegaram à conclusão de que existem algumas limitações dos indicadores de patentes porque as fontes do progresso tecnológico e da inovação são variadas e complexas. Entendem também que nenhum indicador isolado tem a capacidade de análise do todo. Por outro lado, chegaram à conclusão que as estatísticas de patentes por serem coletadas há mais de um século, e porque comportam uma alta comparabilidade internacional e uma alta comparabilidade com gastos em pesquisa e desenvolvimento, possibilitam uma desagregação setorial detalhada, constituindo-se assim em um forte elemento de análise.

Assim, utilizamo-nos dos registros de patentes na Organização Mundial da Propriedade Intelectual para avaliação dos países segundo seus registros de invenções e inovações tecnológicas. Tomamos na Figura 3 os números de Estados Unidos e China relativos a propriedades intelectuais, aqui especificamente as patentes, não inclusas portanto as marcas, desenhos industriais ou direitos autorais, para demonstração da competição principal atualmente, com o Japão, que outrora fora o segundo país nos registros de patentes e com o Brasil, que apresenta pouquíssima inovação, embora com atividade econômica complexa (como observamos na leitura da tabela 1 sobre marcas).

\footnotetext{
${ }^{65} \mathrm{O}$ registro da patente garante ao seu proprietário o uso exclusivo por vinte anos, mas após esse período o invento cai em domínio público, podendo então ser livremente usada pelos demais concorrentes.
} 
Figura 4 - Crescimento das propriedades intelectuais - Estados Unidos, China, Japão e Brasil - 2002 - 2016 em gráfico comparativo.

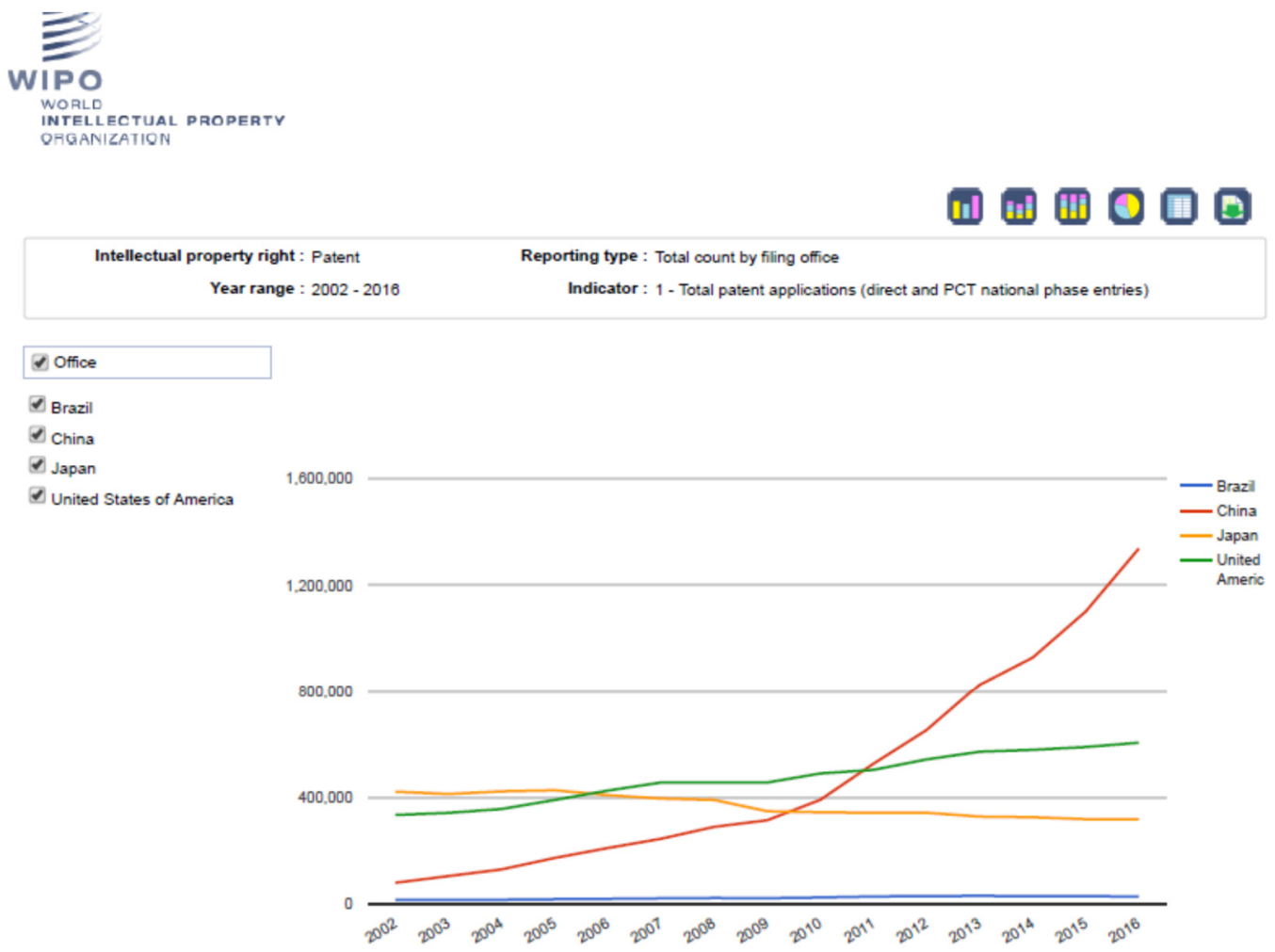

Fonte: Elaboração do autor a partir de mecanismo de interação site-internauta da Organização Mundial da Propriedade Intelectual. 
Figura 5 - Crescimento em tabela das propriedades intelectuais - Estados Unidos, China, Japão e Brasil - 2002-2016

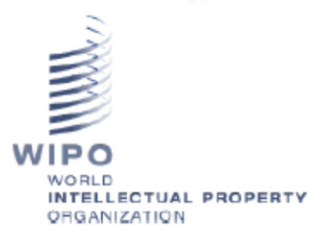

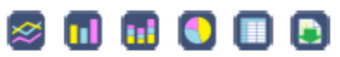

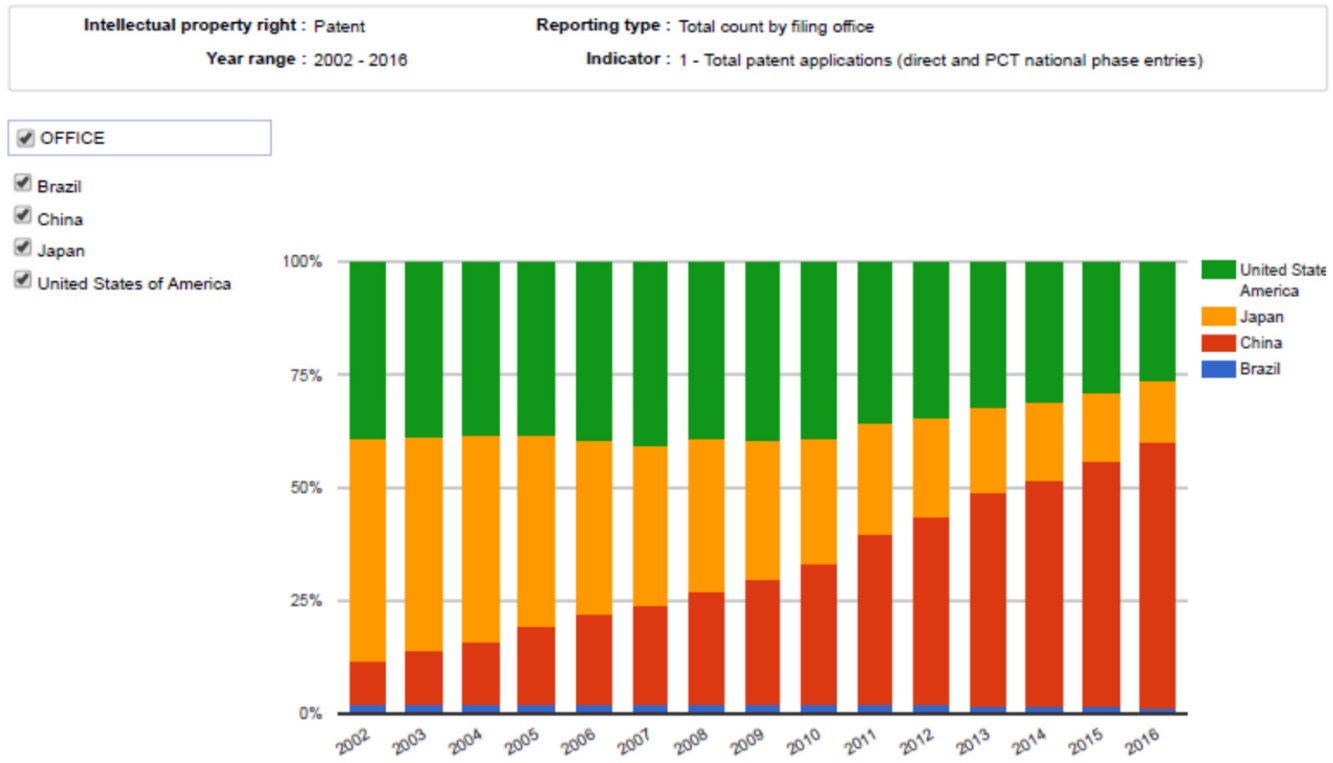

Fonte: Elaboração do autor a partir de mecanismo de interação site-internauta da Organização Mundial da Propriedade Intelectual.

Não é apenas a quantidade de patentes registradas na China pelas empresas chinesas que demonstram a sofisticação de sua economia. O espectro de campos tecnológicos de patentes é vasto e engloba vários setores de ponta.

Tabela 8 - Patenteamento na China por setores em porcentagem - 2016:

\begin{tabular}{l|l}
\hline Área Tecnológica & Participação \\
\hline Maquinário elétrico - aparato - energia & 6.70 \\
\hline Tecnologia computacional & 6.45 \\
\hline Comunicação Digital & 6.12 \\
\hline Mediações & 5.95 \\
\hline Farmacêuticos & 5.04 \\
\hline Equipamentos de máquinas & 4.29 \\
\hline Material básico - químicos & 4.24 \\
\hline Materiais - metalurgia & 4.18 \\
\hline Alimentos - química & 4.15 \\
\hline Outras máquinas especiais & 4.04 \\
\hline Outros & 48.84 \\
\hline
\end{tabular}


Fonte: Elaboração do autor a partir de dados do site da Organização Mundial da Propriedade Intelectual

O crescimento do número de pedidos e de registros concedidos de patentes demonstra inovação, inequivocadamente, mesmo para aqueles que demonstram um certo ceticismo com esse crescimento e buscam encontrar problemas no crescimento chinês.

Não parece proceder as alegações de que o escritório de patentes chinês seria mais flexível que seus similares em outros lugares quanto ao rigor na análise de mérito e aprovação de patentes ${ }^{66}$, como se vê em análises de jornalistas americanos, por exemplo. Para Wei, Xie e Zhang (2017), o percentual entre os pedidos feitos e os registros deferidos no órgão chinês está no patamar de $30 \%$ a $40 \%$, que é uma média mundial e acima de outros países dos Brics (Brasil e Índia na casa dos 20\%), mas abaixo daqueles concedidos nos Estados Unidos e Coréia do Sul (40 e 50\%).

Os mesmos estudos de Wei, Xie e Zhang (2017) mostram que os pedidos de patentes por estrangeiros na China caíram de 20\% em 2005 para 7\% em 2014, o que mostra um crescimento endógeno, já que os registros gerais cresceram no mesmo período. No mesmo sentido os escritórios estrangeiros têm verificado aumento no número de pedidos e de concessões de patentes a empresas chinesas. De 1995 a 2014 os escritórios de patentes dos países desenvolvidos concederam 30\% a mais por ano de patentes a empresas chinesas. No caso dos Estados Unidos, o número de patentes concedidos pela USPTO (Escritório de Patentes e Marcas Registradas dos Estados Unidos) aumentou de 62 em 1995 para 7.236 em 2014. Ainda aquém das empresas japonesas (53.849 em 2014) e das empresas alemãs (16.550 em 2014), mas enquanto essas tiveram aumento de entre $3 \%$ a $7 \%$ no período, o crescimento das empresas chinesas variou de 21 a 38\%, acima também das empresas da Coréia do Sul, que subiram de 1.161 patentes em 1995 para 16.469 em 2014, com aumento variando de 14 a $16 \%$ no período.

Portanto, o aumento de patentes de empresas chinesas seja na própria China, seja nos demais países é inquestionável. Os dados confirmam também nossos levantamentos e análises de que ao lado de Estados Unidos e China, Japão, Coréia do Sul e Alemanha são os países que detêm a maior quantidade de patentes de invenção e que

\footnotetext{
${ }^{66} \mathrm{Na}$ análise de mérito, o órgão concedente deve analisar se a invenção atende aos requisitos de novidade, atividade inventiva (passo além do estado da técnica) e aplicação industrial. Em momentos de grande acúmulo de pedidos, não é raro os órgãos deixarem de apreciar algum desses requisitos, como o Brasil, em que o INPI diante de um acúmulo que tem levado de 11 a 13 anos para analisar, tem relaxado na apreciação de algum desses requisitos, o que na prática, acaba levando a questão para o Judiciário.
} 
apresentam nessas duas décadas iniciais do Século XXI os maiores índices de inovação e desenvolvimento tecnológico.

Vale dizer que o aumento da inovação e dos registros de patentes não pode se dar sem uma robusta e diversificada economia, pois como demonstrou Chang (2014), é preciso estar produzindo para poder gerar inovação. A inovação não vem do nada, do laboratório apenas, mas também do próprio processo de produção.

Neste sentido a ascensão da China se faz sentir em todos os setores e em seu poder econômico e, em consequência, político, e é inconteste conforme as diversas estatísticas já apresentadas ao longo desta tese, com base nas propriedades intelectuais, mas sobretudo corroborado pelo seu notável desempenho na participação do comércio internacional. Observamos essa ascensão pela participação chinesa nas exportações mundiais, demonstrada na tabela 4, elaborada com dados obtidos a partir da página de internet da Organização Mundial do Comércio referente às exportações de mercadorias medidas nos anos de 1948, 1953, 1963, 1973, 1983, 1993, 2003 e 2016.

Tabela 9 - Participação nas exportações mundiais - em porcentagens

\begin{tabular}{l|l|l|l|l|l|l|l|l|l}
\hline & 1948 & 1953 & 1963 & 1973 & 1983 & 1993 & 2003 & 2016 & 2019 \\
\hline EUA & 21,6 & 14,6 & 14,3 & 12,2 & 11,2 & 12,6 & 9,8 & 9,4 & 8,7 \\
\hline China & 0,9 & 1,2 & 1,3 & 1,0 & 1,2 & 2,5 & 5,9 & 13,6 & 13,2 \\
\hline
\end{tabular}

Fonte: Elaboração do autor com dados obtidos no site Organização Mundial do Comércio.

Tabela 10 - Quadro comparativo da economia Estados Unidos - China

\begin{tabular}{l|l|l}
\hline & Estados Unidos & China \\
\hline $\begin{array}{l}\text { PIB 2016 em milhões } \\
\text { de US\$ }\end{array}$ & 18.569 .100 & 11.218 .281 \\
\hline PIB 2017 & 19.485 tri & 12.31 tri \\
\hline PIB 2018 & 20.529 tri & 13.895 tri \\
\hline PIB 2019 & 21.374 tri & 7.995 \\
\hline $\begin{array}{l}\text { PIB 2014-2016 PER } \\
\text { CAPITA }\end{array}$ & 56.064 & 1.8 \\
\hline $\begin{array}{l}\text { Balança comercial } \\
\text { Comércio per capita } \\
\text { 2014-2016 }\end{array}$ & -2.6 & 1.601 \\
\hline $\begin{array}{l}\text { Comércio (\% do PIB) } \\
\text { 2014-2016 }\end{array}$ & 13.9 & 20.0 \\
\hline
\end{tabular}




\begin{tabular}{|c|c|c|}
\hline $\begin{array}{l}\text { Rank no comercio } \\
\text { internacional de } \\
\text { mercadorias } 2016\end{array}$ & 2 & 1 \\
\hline $\begin{array}{l}\text { Rank no comercio } \\
\text { internacional de } \\
\text { serviços } 2016 \\
\text { (transportes, viagens, } \\
\text { etc) }\end{array}$ & 1 & 5 \\
\hline $\begin{array}{l}\% \text { das exportações de } \\
\text { mercadorias }\end{array}$ & $\begin{array}{l}10,7 \text { de produtos } \\
\text { agrícolas, } 9,4 \text { de } \\
\text { combustíveis e minerais, } \\
74,8 \text { de manufaturados e } \\
5,1 \text { outros }\end{array}$ & $\begin{array}{l}3,2 \text { de produtos agrícolas, } \\
2,4 \text { de combustíveis e } \\
\text { minérios, } 94,3 \text { de } \\
\text { manufaturados, e } 0,1 \text { outros }\end{array}$ \\
\hline $\begin{array}{l}\% \text { das importações de } \\
\text { mercadorias }\end{array}$ & $\begin{array}{l}6,8 \text { de produtos agrícolas, } \\
10,7 \text { de combustíveis e } \\
\text { minerais, } 78,4 \text { de } \\
\text { manufaturados e } 4,2 \\
\text { outros. }\end{array}$ & $\begin{array}{l}9.5 \text { de produtos agrícolas, } \\
21,3 \text { de combustíveis e } \\
\text { minerais, } 64,4 \text { de } \\
\text { manufaturados e } 4,8 \text { outros }\end{array}$ \\
\hline $\begin{array}{l}\% \text { das exportações de } \\
\text { comércio e serviços }\end{array}$ & $\begin{array}{l}11,6 \text { de transportes, } 28,2 \\
\text { de viagens, } 3,6 \text { de } \\
\text { serviços relacionados a } \\
\text { bens de consumo, } 56,6 \text { de } \\
\text { outros serviços } \\
\text { comerciais (dentro desses } \\
2 \text { últimos itens a } \\
\text { exportação de } \\
\text { propriedades industriais } \\
\text { (marcas, patentes, } \\
\text { desenho industrial, } \\
\text { indicações geográficas) } \\
\text { responde por } 29,5 \%\end{array}$ & $\begin{array}{l}12,1 \text { de construção, } 55,1 \\
\text { outros serviços comerciais, } \\
24,2 \text { de tecnologia da } \\
\text { informação e comunicação e } \\
8,7 \text { outros. Não há } \\
\text { especificação de } \\
\text { propriedade industrial }\end{array}$ \\
\hline
\end{tabular}

Fonte: Elaboração do autor a partir de dados constantes no site de Organização Mundial do Comércio.

Observamos que nos que diz respeito aos investimentos em pesquisa e desenvolvimento a China também acompanha os esforços dos Estados Unidos, ao contrário de países como o Brasil, ainda bastante carente de investimentos nessa área. A China investiu em 2015, 2,1\% de seu produto interno bruto em pesquisa e desenvolvimento, enquanto a média dos países membros da OCDE é de 2,4\%. Os Estados Unidos investiram 2,7 \% ${ }^{67}$ e o Brasil investiu em 2014 1,2\%.

A ascensão das empresas chinesas no mundo é incontroversa em dois campos importantes da indústria por trazerem juntos avanços em outras áreas correlatas tecnologicamente. $\mathrm{O}$ da indústria automobilística e a dos aparelhos de telefones celulares

\footnotetext{
${ }^{67}$ Disponível em: http://www.oecd-ilibrary.org/. Acesso em 28/02/2018.
} 
são setores que trazem junto o desenvolvimento dos setores de fornecimento de peças, acarretando uma inovação em cadeia. Se os telefones celulares trazem em média mais de mil patentes em sua fabricação, a de um carro atinge duas centenas.

No campo dos veículos automotores, a expansão da indústria se dá de forma visível no território com a consequente expansão também das rodovias e infraestrutura necessária ao seu desenvolvimento (a rigor, no caso dos aparelhos celulares com uso da internet também se verifica a expansão dos cabos de transmissão de fibras óticas). A partir da instalação da estatal FAW (First Automobile Works) em 1953, quando os carros que circulavam no país eram importados, a China inicia sua indústria automobilística que conhecerá mais tarde um vertiginoso crescimento, em especial com a abertura na década de 1980, através de incentivos a parcerias como as joint-ventures com empresas estrangeiras, em processo de aquisição de tecnologia do exterior. Hoje essas empresas parceiras ainda existem, mas as empresas totalmente chinesas já estão entre as dez maiores produtoras da China tanto para o mercado interno como para o mercado para exportação. A China é hoje o maior produtor e o maior exportador de veículos no mundo, com predomínio inconteste no segmento dos carros populares, e avançando também no segmento dos carros de luxo e de caminhões pesados.

Mapa 1 - Localização das montadoras chinesas

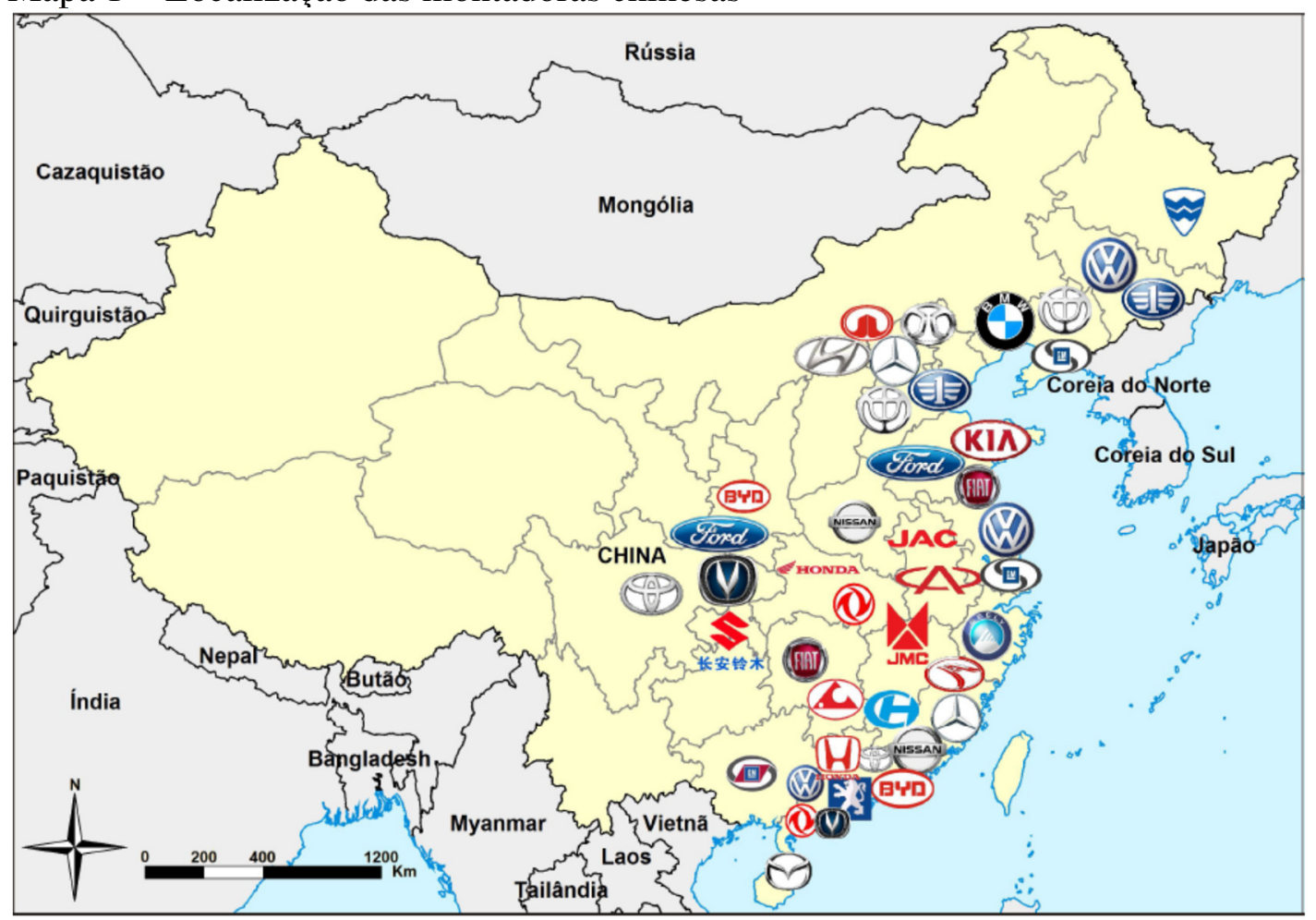

Mapa confeccionado por Priscila Helena Lee a partir de ilustração do relatório de análise de mercado citado como fonte. Fonte: Relatório de Análise de Mercado: A Indústria automotiva da 
China. 2010. Elaborado pela consultoria APCO Worldwide para o Governo Israelense disponível em: http://www.export.gov.il/uploadfiles/03_2012/chinasautomotiveindustry.pdf

Destacamos a localização das montadoras automobilísticas para confronto do mapa de rodovias e estradas de ferro, uma vez que alguns autores entendem que a integração espacial é fator decisivo para o crescimento econômico. No estudo que busca comparar o desenvolvimento histórico da China e da Europa, Rosenthal e Wong (2011, p. 208), focando o período de 1650 a 1800 para mostrar a importância das raízes históricas precedentes da revolução industrial, afirmam que "Como mostra o mapa 7.1, a China sob Qing era um grande espaço político integrado como tinha sido sob Hun e muito como é hoje a República Popular". Hoje, conforme mostram os mapas 1 e 2 e a figura 5, a produção automobilística se assenta em um espaço amplamente integrado por rodovias e ferrovias.

Mapa 2 - Vias expressas rodoviárias na China

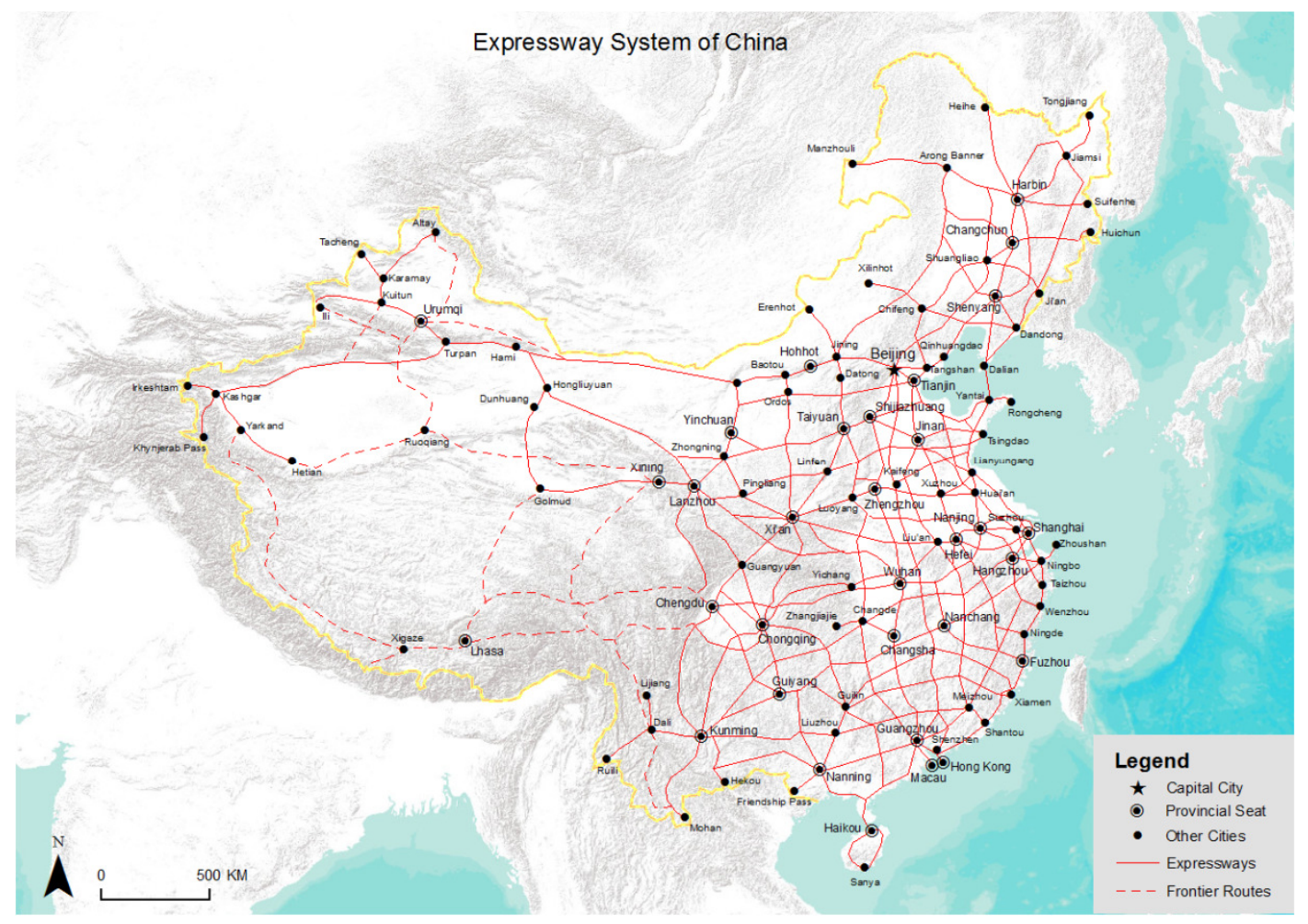

Fonte: Wikipedia. Disponível em: https://en.wikipedia.org/wiki/Expressways_of_China. Acesso em 19/06/18 
Figura 6 - Estradas de ferro na China em 2018

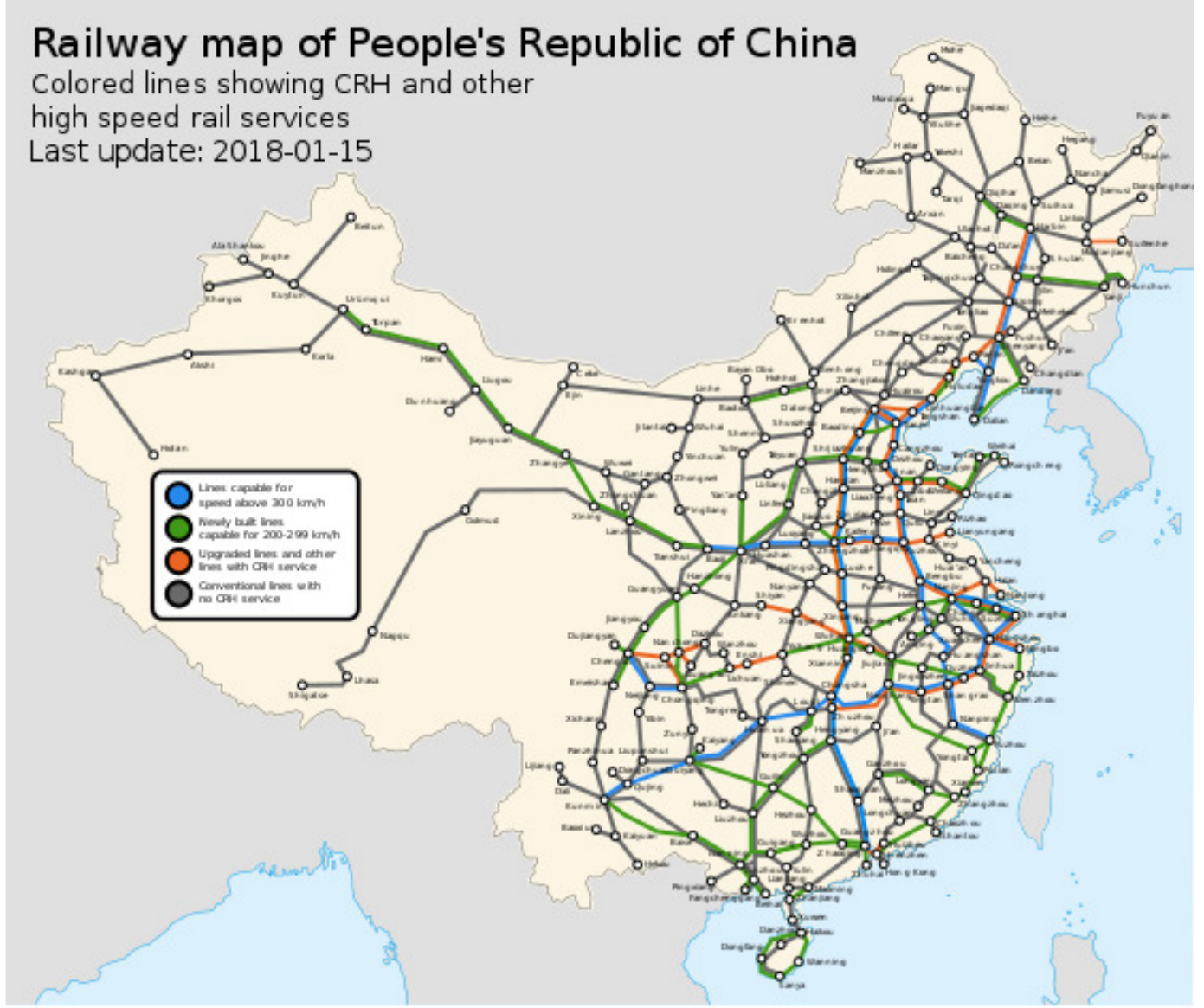

Fonte: Wikipédia. Disponível em: https://en.wikipedia.org/wiki/Rail_transport_in_China. Acesso em 19/06/18

A demonstração da expansão da infraestrutura no território, destacando-se a denominada "Nova Rota da Seda", se faz não apenas para lembrar a atualidade da geopolítica de Mackinder, mas sobretudo para que não esqueçamos que o advento da internet, suas redes com fluxos virtuais e o desenvolvimento da tecnologia 5G, não se fazem paralelas ou apartadas da realidade territorial e física, eis que aquelas dependem dos cabos submarinos, antenas e toda a infraestrutura de suporte ao virtual.

No mesmo ritmo que segue essa predominância nos diversos setores da produção industrial seguem igualmente os litígios e disputas comerciais, ocorrendo em anos mais recentes os embates envolvendo questões ligadas à propriedade intelectual, o que demonstra o incômodo que a China causa aos países detentores tradicionais do conhecimento tecnológico (Figura 7). 
Figura 7 - Quadro de disputas comerciais envolvendo a China

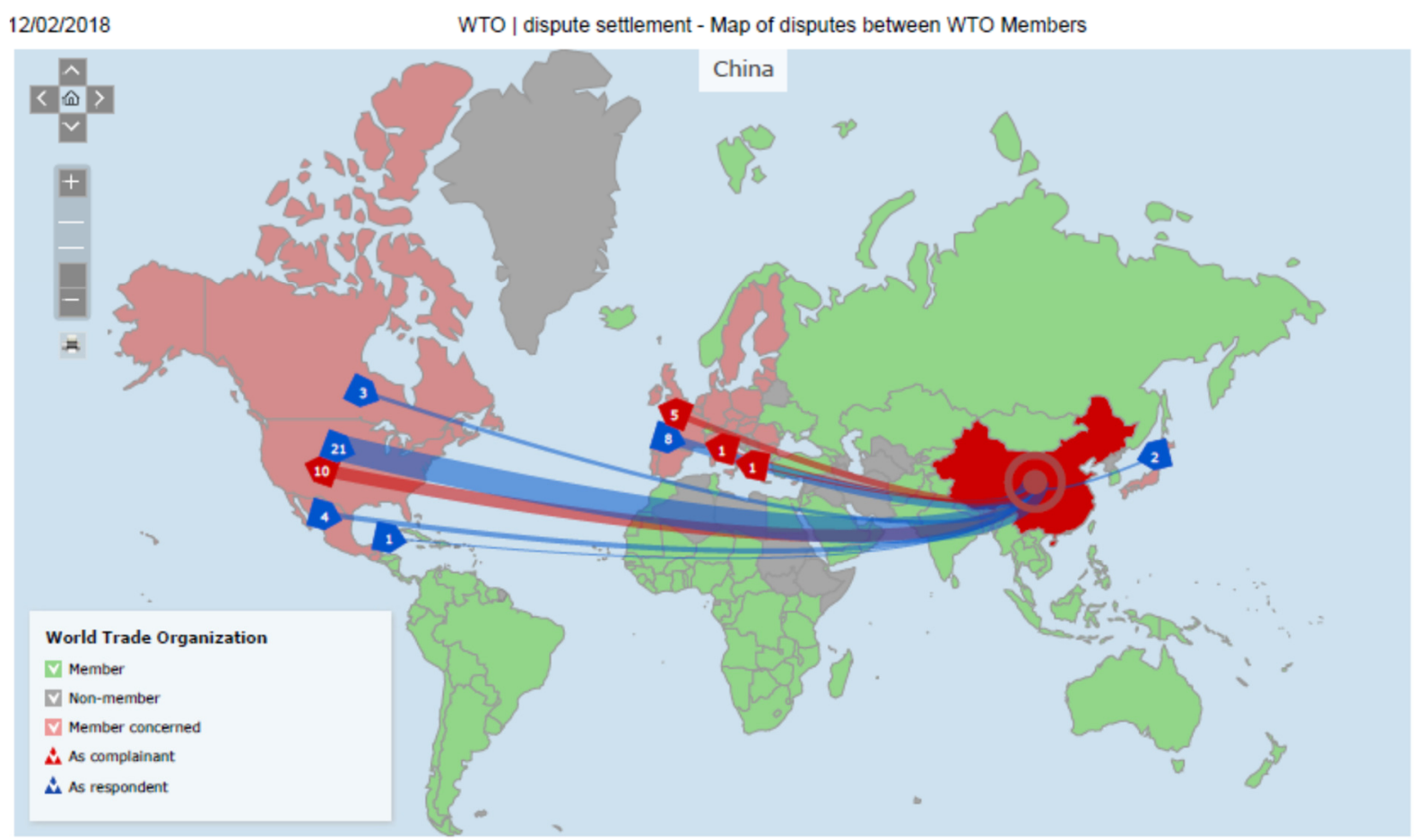

Fonte: Site de Internet da Organização Mundial do Comércio

Observamos que em 2018 as disputas envolvendo a China no âmbito da Organização Mundial do Comércio ocorrem com os países do hemisfério norte e não apenas tendo a China no polo passivo das controvérsias, mas como também no polo ativo, em que busca colocar no banco dos réus países da Europa, os Estados Unidos e o Japão. 


\section{Capítulo 12}

\section{A competição entre Estados Unidos e China}

A fim de se vislumbrar os caminhos da competição entre os dois países que se firmam como potências em propriedades industriais, e em consequência, a nosso ver como potências militares, políticas e econômicas, em um mundo cada vez mais bipolar, retomamos brevemente o histórico de Estados Unidos e China dentro do contexto mundial no momento em que foram estabelecidos os marcos regulatórios iniciais das marcas e patentes.

No período da Convenção Internacional da Propriedade Industrial de Paris em 1883 e da Convenção dos Direitos de Autor em 1886 vivia-se o ápice do domínio europeu. Os Estados Unidos, embora passando por grande revolução industrial, e a China, ainda suscetível ao poder japonês, não eram autores dominantes na cena política internacional. Para Kennedy (1989, p.191) "No inverno de 1884-1885, as grandes potências do mundo, junto com alguns estados menores, reuniram-se em Berlin numa tentativa de chegar a um acordo sobre comércio, navegação e limites na África Ocidental e no Congo" e que tal Conferência, sob muitos aspectos "pode ser considerada, simbolicamente, como o zênite do período de predomínio da Velha Europa nos assuntos globais”. Pela Ásia o autor faz referência ao Japão que não participou, embora passasse por rápida modernização, e os Estados Unidos, embora participante pelas questões de comércio e navegação, "sob a maioria dos outros aspectos os Estados Unidos continuavam fora do cenário internacional".

Os Estados Unidos, porém, já despontavam como uma potência industrial no final do século XIX, e que foi confirmado nas décadas seguintes. É interessante e pertinente analisar o período em que os Estados Unidos se tornam a nação mais industrializada do mundo, não apenas para comparar mas estabelecer semelhanças de processos que verificamos praticamente cem anos mais tarde com a China.

Vejamos sua evolução industrial em comparação aos três maiores produtores industriais da Europa: 
Tabela 11 - Níveis de industrialização per capita. 1880-1938 (relativo à G.B. em $1900=100)$.

\begin{tabular}{l|l|l|l|l|l}
\hline & 1880 & 1900 & 1913 & 1928 & 1938 \\
\hline \multirow{2}{*}{ E.U.A. } & 38 & 69 & 126 & 182 & 167 \\
\hline Grã-Bretanha & 87 & {$[100]$} & 115 & 122 & 157 \\
\hline Alemanha & 25 & 52 & 85 & 128 & 144 \\
\hline França & 28 & 39 & 59 & 82 & 73 \\
\hline
\end{tabular}

Fonte: KENNEDY, Paul. Ascensão e Queda das Grandes Potências (1989, p. 197)

Tabela 12 - Potencial industrial total das potências em perspectiva relativa, 18801938 (Reino Unido em $1900=100$ )

\begin{tabular}{|l|l|l|l|l|l|}
\hline & 1880 & 1900 & 1913 & 1928 & 1938 \\
\hline E.U.A. & 46,9 & 127,8 & 298,1 & 533 & 528 \\
\hline $\begin{array}{l}\text { Grã-Bretanha } \\
\text { Alemanha }\end{array}$ & 73,7 & {$[100]$} & 127,2 & 135 & 181 \\
\hline França & 27,4 & 71,2 & 137,7 & 158 & 214 \\
\hline
\end{tabular}

Fonte: KENNEDY, Paul. Ascensão e Queda das Grandes Potências (1989, p. 197)

Kennedy elabora as tabelas comparativas a partir de produção de ferro e aço, consumo de energia, baseado no carvão, e potencialidades industriais, ou seja, os dados econômicos, para "Compreender as transformações a longo prazo que afetaram o equilíbrio de poder internacional entre a década de 1880 e a Segunda Guerra Mundial” (KENNEDY, 1989, p. 195).

Percebe-se pelos estudos comparativos o declínio da Grã-Bretanha nesse período e a ascensão da Alemanha e dos Estados Unidos, no fenômeno que muitos analistas denominam de segunda revolução industrial. Aí, portanto a ascensão americana.

No início deste século, os Estados Unidos ainda eram o poder dominante no mundo. Para Raul Ornelas (2002, p. 126) que estudou os mercados das grandes empresas transnacionais, no período de 1985 a 2000, a maior parte delas tinha origem em solo norteamericano. Ornelas (2002, p. 127) afirma que seu trabalho argumenta duas ideias centrais:

"Em primeiro lugar, a renovação da liderança econômica mundial dos Estados Unidos. Através do estudo do comportamento das empresas transnacionais mais importantes, constatamos que as firmas estadunidenses alcançaram: a) a recuperação de quotas de mercado nas atividades mas dinâmicas e rentáveis: informática, eletrônica, 
telecomunicações, indústria petroleira e balança comercial; b) o controle majoritário dos lucros empresariais. Em segundo lugar, propomos que a posição líder das empresas estadunidenses afirma a hipótese de que a mal chamada 'guerra contra o terrorismo' constitui um posicionamento estratégico (conter, enfraquecer, levar vantagem) contra a China, principal potência econômica e militar que pode desafiar a hegemonia dos Estados Unidos, e não uma 'resposta' à recessão ou ao declive estadunidense, como sugerem as interpretações mais comuns sobre a ofensiva estadunidense na Ásia Central" (ORNELAS, 2002, p. 127).

Trabalhando com as estatísticas de distribuição das empresas desses setores (informática, eletrônica, petroleira, bancos) e os lucros, Ornelas (2002) demonstra que as empresas norte-americanas tinham até o ano de 2000 a dianteira no mundo dos negócios.

Já a China, como vimos, teve períodos demarcáveis de importância na consolidação de sua indústria, mas, de modo genérico aqui podemos pontuar o início de sua ascensão moderna também nos finais dos anos 1960 e 1970 em que a potência americana enfrentava problemas pela competição de Alemanha e Japão. Kennedy (1989, p. 393) menciona a previsão de Richard Nixon, em julho de 1971 de que a partir daquele momento haveria cinco centros de poder econômico além dos Estados Unidos e União Soviética, que seriam a Europa Ocidental, o Japão e a China.

Kennedy (1989) parece ter acertado em suas previsões. Para tomarmos como exemplo a indústria automobilística, a ascensão chinesa é notória. A automobilística foi, nesses anos, a ponta de avanço da indústria em geral pelo fato da cultura da velocidade que se alastrava pelo mundo e por ser uma indústria fundamental, no caso de nosso foco, pela quantidade de patentes que envolvem a montagem de um veículo automotor,

A ascensão chinesa leva a controvérsias comerciais que vão parar nos tribunais de justiça, como vemos em capítulo próprio, e não raras vezes em retaliações e medidas protetivas. Em uma busca simples no site do jornal norte-americano New York Times tendo como parâmetro as palavras "China" e "WTO" encontramos dezenas de notícias de litígios e acusações entre as duas nações. A maioria das acusações, tanto de um lado como de outro, diz respeito a subsídios irregulares do estado a produtores nacionais e à manipulação de regras de comércio internacional.

Até 2007, o governo americano procurava usar a diplomacia para tratar das desavenças comerciais com a China. Com um déficit na balança comercial de 232 bilhões de dólares naquele ano, o governo Bush tomou a iniciativa de instaurar um litígio perante 
a Organização Mundial do Comércio tendo como objeto da controvérsia as barreiras comerciais e a pirataria de propriedade intelectual praticadas pela China.

O presidente Trump, mais recentemente, anunciou o propósito de levantar barreiras contra a China, novamente na área de propriedade intelectual. Ainda em fase de investigações (em março de 2018) a suspeita é de que as empresas chinesas exigem "compartilhamento de segredos industriais ou comerciais americanos em troca de investimentos ou acesso ao mercado asiático" (CARAZZAI, 2018, p. A24).

No mesmo mês de março de 2018, o presidente americano vetou a compra por uma empresa de Cingapura de ações que dariam o controle da empresa Qualcomm, fabricante de semicondutores à empresa asiática. Para o consultor Paul S. Triolo, da Consultoria Eurasia Group “Com esta ação. a administração Trump está sinalizando que atuará para proteger a economia e a segurança nacional, que é crescentemente vista como sendo uma mesma coisa quando diz respeito à ascensão da China como uma potência tecnológica" (SWANSON, KANG e RAPPEPORT, 2018) ${ }^{68}$.

A preocupação dos governantes americanos em torno da ascensão chinesa dos últimos dez ou quinze anos, no entanto, tem raízes mais antigas. Após a segunda guerra mundial os Estados Unidos detinham a metade da riqueza mundial e, segundo Noam Chomsky (2017, p.95) "dispunham de níveis incomparáveis de segurança e alcance global". Para o autor, a independência da China em 1949 levou formuladores da política externa americana, como George Kennan a denominá-la de "perda da China". Para Chomsky, o termo “perda” pressupõe que os Estados Unidos, antes, “ 'possuíam' a China por direito bem como eram donos da maior parte do restante do mundo, algo que pensavam os estrategistas do pós-guerra" (CHOMSKY, 2017, p. 96). Chomsky situa na independência da China o próprio início da decadência americana.

Chomsky, por outro lado, embora afirme que os Estados Unidos vêm perdendo poder no mundo desde o pós-guerra e que seu declínio é uma realidade, não vê a China como um novo poder hegemônico. Para Chomsky (2017, p. 93) os Estados Unidos continuam a ser "o maior poder dominante" e o mundo se torna multipolar. A China ou a Índia não teriam a possibilidade de ultrapassarem os Estados Unidos porque continuariam sendo "países muito pobres e com enormes problemas internos".

Mas, em relação à China, continuando a apontar problemas como a demografia (que abriu uma janela de pessoas economicamente ativas, mas que vai logo

\footnotetext{
${ }^{68}$ Tradução nossa.
} 
se fechar), faz uma ressalva, pelo menos minimamente contraditória com a assertiva geral de que não se tornaria uma potência:

\begin{abstract}
"A China é o maior centro industrial do mundo e, em grande medida, atua como linha de montagem para potências industriais avançadas em sua periferia e multinacionais ocidentais. É provável que isso mude com o decorrer do tempo. A indústria propicia habitualmente as bases para a inovação, e quase sempre também para a invenção, como agora vem ocorrendo, às vezes, na China. Um exemplo que impressionou os especialistas ocidentais foi o fato de a China assumir a dianteira no crescente mercado de painéis solares, não apenas com base na mão de obra barata, mas no planejamento coordenado e, cada vez mais, na inovação" (CHOMSKY, 2017, p. 93).
\end{abstract}

Samuel Huntington (2010) também, nos anos 1990, previu um declínio do poder americano e ameaças ao ocidente vindo especialmente do radicalismo islâmico e da ascensão da economia chinesa. Em "O choque das civilizações", Huntington ponderava, contudo, que esses processos de mudança de poder são lentos, lembrando que a ascensão do ocidente também fora um processo lento.

Afirmando existir duas imagens do poder ocidental, em oposição ao do declínio, existe, para o autor, a imagem da persistência do poder do Ocidente em virtude de ainda (HUNTINGTON, 2010, p. 126): a) dominar o sistema bancário internacional; b) controlar as moedas fortes; c) serem os principais consumidores; d) fornecer a maioria dos bens acabados do mundo; e) dominar os mercados internacionais de capitais, f) exercer liderança moral; g) capazes de maciça intervenção militar; h) controlarem as rotas marítimas; i) realizarem a maior parte da pesquisa e desenvolvimento de tecnologia de ponta; j) controlarem o ensino técnico de ponta; k) dominarem o acesso ao espaço; 1) dominarem a indústria aeroespacial; $m$ ) dominarem as comunicações internacionais e $n$ ) dominarem a indústria de armamentos de alta tecnologia.

A ascensão da China no comércio internacional e sua importância para a economia mundial não é mensurável apenas pelo tamanho de seu produto interno bruto (12,31 trilhões em 2017 - 14,343 trilhões em 2019) ou pelo crescimento econômico (6,9 \% em 2017 e 6,109 em 2019, apesar da crise que assola o mundo) como noticiam os meios de comunicação. Como vimos há um índice ainda mais importante por medir a qualidade desse crescimento, que é o índice de crescimento e detenção de propriedades intelectuais. No caso das patentes o crescimento chinês é vigoroso. 
Como evidência desse avanço, servimo-nos agora de um quadro comparativo das patentes em vigor hoje nos dois países. Como o direito de patente perdura pelo prazo de 20 anos, após o que cai em domínio público, o dado de patentes em vigor é importante porque aponta as patentes aprovadas acumuladas, portanto, nos últimos 20 anos.

Tabela 13 - Patentes em vigor na China e nos Estados Unidos

\begin{tabular}{l|l|l}
\hline Ano & $\begin{array}{l}\text { Patentes em } \\
\text { vigor nos } \\
\text { Estados Unidos }\end{array}$ & $\begin{array}{l}\text { Patentes em } \\
\text { vigor na China }\end{array}$ \\
\hline 2007 & 1.818 .531 & 271.917 \\
\hline 2008 & 1.872 .872 & 337.215 \\
\hline 200 & 1.930 .631 & 438.036 \\
\hline 2010 & 2.017 .318 & 564.760 \\
\hline 2011 & 2.113 .628 & 696.939 \\
\hline 2012 & 2.239 .231 & 875.385 \\
\hline 2013 & 2.387 .502 & 1.033 .908 \\
\hline 2014 & 2.527 .750 & 1.196 .497 \\
\hline 2015 & 2.644 .697 & 1.472 .374 \\
\hline 2016 & 2.763 .055 & 2.085 .367 \\
\hline 2017 & 2.984 .825 & 2.670 .384 \\
\hline 2018 & 3.063 .494 & 3.131 .427 \\
\hline 2019 & & \\
\hline
\end{tabular}

Fonte: Elaborada pelo autor a partir de dados obtidos no site da OMPI.

Percebe-se que enquanto os Estados Unidos nos últimos 10 anos tiveram um crescimento de $62 \%$ na quantidade de patentes em vigor, a China teve crescimento de mais de 500\%. Esses números mostram que os Estados Unidos continuam inovando, mas a China apresenta ação inventiva patenteável ainda maior, e se mantido esse crescimento nos próximos anos a China deve ultrapassar os Estados Unidos no número de patentes em vigor.

É de se destacar que para efeitos dos órgãos de propriedade intelectual, a China já ultrapassou os Estados Unidos em patentes em 2019, em virtude da maior quantidade de patentes no escritório internacional do tratado PCT (tabela 13). Esta a 
notícia veiculada no site da Organização Mundial da Propriedade Intelectual de 07 abril de 2020 com a manchete de que a China se tornava a primeira requerente de patentes internacionais, observando no artigo que os Estados Unidos mantinha a primeira posição desde 1978, quando o tratado entrou em operação ${ }^{69}$.

Tabela 14 - Pedidos de patentes nos respectivos órgãos nacionais (inclui nacionais e estrangeiros)

\begin{tabular}{|l|l|l|}
\hline & EUA & China \\
\hline 2009 & 397.997 & 241.435 \\
\hline 2010 & 433.297 & 308.327 \\
\hline 2011 & 440.737 & 436.168 \\
\hline 2012 & 473.475 & 561.404 \\
\hline 2013 & 501.144 & 734.093 \\
\hline 2014 & 509.516 & 837.814 \\
\hline 2015 & 530.658 & 1.010 .524 \\
\hline 2016 & 522.065 & 1.257 .425 \\
\hline 2017 & 525.467 & 1.306 .080 \\
\hline 2018 & 515.180 & 1.460 .244 \\
\hline 2019 & 521.145 & 1.327 .847 \\
\hline
\end{tabular}

Fonte: Organização Mundial da Propriedade Intelectual

Tabela 15 - Pedidos de patentes no PCT (Tratado Internacional de Cooperação de Patentes - Genebra)

\begin{tabular}{|l|l|l|}
\hline & EUA & China \\
\hline 2010 & 45.089 & 12.300 \\
\hline 2011 & 49.206 & 16.396 \\
\hline 2012 & 51.857 & 18.616 \\
\hline 2013 & 57.451 & 21.506 \\
\hline 2014 & 61.488 & 25.542 \\
\hline 2015 & 57.132 & 29.837 \\
\hline 2016 & 56.593 & 43.092 \\
\hline
\end{tabular}

${ }^{69}$ China Becomes Top Filer of International Patents in 2019 Amid Robust Growth for Wipo's IP Services, Treaties and Finances. Disponível em: https://www.wipo.int/pressroom/en/articles/2020/article_0005.html. Acesso em 22/12/2020. 


\begin{tabular}{|l|l|l|}
\hline 2017 & 56.687 & 48.906 \\
\hline 2018 & 56.252 & 53.349 \\
\hline 2019 & 57.840 & 58.990 \\
\hline
\end{tabular}

Fonte: Organização Mundial da Propriedade Intelectual

Observa-se claramente dos índices de patentes que a China avança em percentuais muito superiores aos norte-americanos. A quantidade muito superior de pedidos de registro de patentes pelos chineses a cada ano resulta em uma aproximação da quantidade de patentes em vigor, ou seja, aquelas acumuladas ao longo dos anos. Como uma patente dura vinte anos e depois cai em domínio público, em poucos anos a China alcançará os Estados Unidos mesmo que diminua os pedidos de registros. No tratado internacional para validade mundial, no PCT, essa superação da China no ano de 2019 em que os Estados Unidos se mantiveram estáveis nos últimos cinco anos e a China dobrou seus pedidos de patentes internacionais, demonstra uma presença maior da China nos mercados internacionais com produtos sofisticados.

Em que pese a proteção de propriedade intelectual se prestar à proteção do conhecimento e que se presta a dificultar o desenvolvimento da concorrência, a China conseguiu fazer o seu catch up tecnológico em um espaço de tempo bastante curto. $\mathrm{O}$ tempo levado pelos Estados Unidos para assumir a dianteira industrial do mundo (de 1880 a $1930=50$ anos) conforme tabela 9 e 10, a China atingiu em 40 anos (1978 a 2019) se considerarmos a patente como o coração da indústria inovativa.

Embora centremos as análises de marcas e patentes a partir do final da primeira década do século, porque são os dados disponibilizados pela OMPI, e talvez seja o caso de se questionar a razão de não disporem de dados anteriores, ainda que fossem parciais para alguns países, há estudos de patentes em períodos anteriores, como a de Johannes Liegsalz e Stefan Wagner (2012) realizado com os dados do Escritório Estatal de Propriedade Intelectual da China, no período de 1990 a 2002. Na época do estudo (2011, publicado em 2012) o escritório havia se torando no $3^{\circ}$ do mundo em pedidos de registro, atrás do americano e do japonês. Com o objetivo de analisar o tempo de duração de análise para concessão de pedidos de patentes, encontrou a média de 4,71 anos, com variações nas 30 áreas tecnológicas analisadas.

Liegsalz e Wagner (2012) atribuem o crescimento de pedidos de patentes ao crescimento da economia da China e a adesão aos tratados internacionais como o Acordo Trips e o PCT e chegaram à conclusão de que para chineses e outros asiáticos o tempo 
para análise e concessão da patente era mais rápido, e em especial em campos tecnológicos que são importantes para a China. Não conseguiram afirmar a razão, levantando a hipótese até da facilidade da língua e do conhecimento do ambiente burocrático do escritório chinês, ressaltando que, pela legislação internacional o escritório local não pode dar tratamento diferente entre nacionais e estrangeiros. Mas o que importa deste estudo é que após analisar milhares de pedidos de patentes e concessões no período de dez anos, os autores não questionam a validade e correção dos procedimentos do escritório chinês, em muitos aspectos parecidos com o dos outros países.

Este estudo, que cita outros estudos parecidos, portanto, desmente notícias de mídia norte-americanas que alegam que o escritório chinês seria mais "flexível" na concessão de patentes e daí a razão do crescimento das patentes chinesas. Raciocínio este que não se sustenta, dado que empresas estrangeiras também patenteiam na China, empresas chinesas também patenteiam no exterior, e empresas chinesas superaram os Estados Unidos em 2019 no tratado PCT, que tem critérios internacionais.

Não há como se questionar, assim, a dianteira chinesa hoje no campo das patentes e sua ascensão dentro do campo e do estado da técnica inicialmente estabelecido pelo Ocidente com as suas duas revoluções industriais.

Para David Harvey os direitos de propriedade intelectual é uma das formas modernas de despossessão e uma fonte de renda crucial, e fazendo referência às propriedades afirma que:

"A política de despossessão que equivale a uma vasta aquisição global de propriedades, em grande parte do continente africano, na América Latina, na Ásia central e no que resta das regiões vazias do Sudeste Asiático, tem sido indiscutivelmente liderada pelos chineses, recémchegados a esse campo tradicional de competição entre potências e corporações" (HARVEY, 2012, p. 221).

A China, assim, avança dentro deste sistema. Um sistema que é único. Não há forma alternativa de desenvolvimento que não seja pelo desenvolvimento tecnológico dentro dos contextos dados pelo estado da técnica. E neste ponto se sobressai a importância das marcas e das patentes.

Milton Santos (1996) pondera que, antes, cada ponto da terra desenvolvia e constituía um conjunto local, pelas técnicas, de um sistema político local. Mas que hoje não se dá mais dessa forma. Para Santos (1996):

"O movimento de unificação, que corresponde à própria natureza do capitalismo, se acelera, para hoje alcançar o seu ápice, com a 
predominância, em toda parte, de um único sistema técnico, base material da globalização. Com a emergência do período técnicocientífico, no imediato pós-guerra, o respectivo sistema técnico se torna comum a todas as civilizações, todas as culturas, todos os sistemas políticos, todos os continentes e lugares" (SANTOS, 1996, p. 125).

Trata-se do que Milton Santos (1996, p. 123) denominou de a unicidade técnica, que, ao lado da "unicidade do tempo (com a convergência dos momentos) e de uma unicidade do motor da vida econômica e social" promovem um processo da produção de uma inteligência planetária, constituindo a base da globalização e "das transformações contemporâneas do espaço geográfico".

Neste campo a China também, acusada de incentivar o uso da cópia, chamada pejorativamente de pirataria, trilhou os mesmos caminhos das potências europeias e dos Estados Unidos mais recentemente dos modelos japonês e sul-coreano e promoveu o desenvolvimento a partir de similares estrangeiros, promovendo sua indústria dentro dos mesmos parâmetros técnicos.

Observa-se, aliás, que desde a revolução industrial, todos os países que atingiram o alto grau da industrialização o fizeram através da pirataria tecnológica, para somente depois formularem políticas de proteção da propriedade intelectual. Nesse sentido a Inglaterra, que não era o país mais desenvolvido do mundo, roubou máquinas da Itália e técnicas de Flandres e Países Baixos, pouco antes de fazer a revolução, os Estados Unidos importaram ilicitamente máquinas de tear e técnicos da Inglaterra para fazer sua revolução, o mesmo acontecendo com os demais países da Europa ocidental e o Japão, e a Coréia do Sul, mais recentemente, que praticou engenharia reversa para estabelecer sua indústria (ANDAKU, 2016; e CHANG, 2004).

Seguindo desta forma o mesmo caminho das outras nações industrializadas e dada a unicidade técnica cada vez mais presente como base material do atual período, reforçada pela cadeia produtiva global, a China e suas empresas avançam dentro do mesmo sistema a que se viu atrasada há poucas décadas. Para superação do atraso adotam os sistemas de padronizações industriais e comerciais, como o sistema ISO, normas técnicas ${ }^{70}$, e muitos outros sistemas que promovem a uniformização e padronização de

\footnotetext{
${ }^{70}$ No Brasil a Inmetro e a ABNT, por exemplo.
} 
métodos organizativos e produtivos. Hoje existem mais de 150 mil sistemas de padronização na China, sete vezes mais que na União Europeia ${ }^{71}$.

No caso do sistema International Organization for Standartzation (ISO), o site da entidade informa que ela "foi fundada com a ideia de responder a uma questão fundamental: Qual a melhor forma de fazer isso?"72 E afirma que a certificação no sistema traz benefícios quantificáveis economicamente, como agilização dos processos, inovação e ganho de escala e criação e entrada em novos mercados.

De acordo com os dados da organização as empresas na China obtiveram a certificação ISO 9001, entre 1993 a 2016, de 340.210 sistemas de gerenciamento. Já as empresas nos Estados Unidos, no mesmo período, obtiveram 28.581 certificações.

Em relação ao ISO 20000 a China obteve 1.666 certificações, enquanto os Estados Unidos 175. Contudo, é preciso ressaltar que a busca por certificações parece ser uma preocupação mais europeia e asiática do que norte-americana. Os países europeus como Alemanha (104 ISOs 20000, 56.445 ISOs 9001), Reino Unido (217 ISOs 20000; 34.311 ISOs 9001 ) e Itália (119 ISOs 20000; 137.835 ISOs 9001) e Japão (285 ISOs 20000; 44.456 ISOs 9001), possuem em geral mais certificações que os Estados Unidos.

Essas certificações são fundamentais para a participação no que é denominado de global value chain, ou seja, na cadeia de valor global. Trata-se da cadeia produtiva global, na qual as empresas participam com a produção de apenas partes da mercadoria, na parte que é mais competitiva no resultado do produto final, seja pelo fato da localidade ter a matéria prima mais barata, seja porque ali já se obteve uma qualificação da mão de obra. Assim, com essas certificações a China e suas empresas se mostram qualificadas a produzirem para as empresas do Ocidente.

A competição entre Estados Unidos e China por uma hegemonia ou por uma hegemonia partilhada por essas duas nações reflete fundamentalmente para o restante do mundo, com graves repercussões espaciais. Como seria o mundo com a hegemonia americana única. Como será com a hegemonia chinesa se ela se realizar?

Milton Santos (2002, p. 119), lembrando J. Thibault que diz que a ciência tornou-se uma força produtiva direta e reconhecendo a constituição da pesquisa como pilar das grandes firmas afirma que: "Como vimos, é por intermédio dos progressos

\footnotetext{
71 Disponível em http://parisinnovationreview.com/articles-en/chinas-standardization-strategies. Acesso em 18/06/18.

72 No original “what's the best way of doing this?”. Disponível em: https://www.iso.org/benefits-ofstandards.html. Acesso em 19/06/18.
} 
técnicos assim obtidos que os monopólios e as corporações afirmam seu poderio sobre as outras firmas e sobre os países menos desenvolvidos". E que nos países subdesenvolvidos: "a contemporaneidade entre dependência tecnológica no mais alto grau e início de industrialização acarreta a instalação de firmas que já aparecem numa situação de concentração", o que significa uma monopolização (SANTOS, 2002, p. 134). 


\section{Capítulo 13 \\ O papel do Estado e a relação com as empresas}

O economista sul coreano Ha Joon Chang (2004), professor na Universidade de Cambridge, conhecido como um dos principais autores da denominada economia do desenvolvimento, destaca ao longo de toda sua obra a importância do Estado na promoção do desenvolvimento industrial e econômico dos países. Em "Chutando a Escada" (CHANG, 2004) afirma que os países hoje desenvolvidos demoraram para adotar políticas de patentes, esperando que suas indústrias nacionais, copiando e reproduzindo tecnologias estrangeiras, obtivessem um elevado grau de disseminação interna do estado da técnica, para só então passar a proteger suas patentes de invenção e demais propriedades intelectuais como a marca. Para Chang (2004)

"O Estado tanto subsidiava a indústria quanto recorria a diversos programas de investimento público, sobretudo em infraestrutura, mas também na manufatura. Financiava a aquisição de tecnologia estrangeira, às vezes por meios legais, como o financiamento de viagens de estudo e treinamento, outras por meios ilegais, entre os quais figuravam o apoio à espionagem industrial, o contrabando de maquinário e o não reconhecimento de patentes estrangeiras" (CHANG, 2004, p. 35/37).

A análise do período de industrialização norte-americana, cem anos antes, e a arrancada de sua vigorosa indústria é imperativa, na medida em que mostra o fundamental papel do Estado. Para Murphy (2014, p. 59) "A industrialização norteamericana não aconteceu sob um rigoroso laisse-faire. Os primeiros industriais norteamericanos pressionaram por tarifas protecionistas, e ignoraram descaradamente as patentes britânicas sobre as máquinas de que precisavam para construir novas fábricas". Para o autor, o que diferenciou a Alemanha e os Estados Unidos neste período da segunda metade do Século XIX foi a adoção de políticas que hoje chamamos de "política de desenvolvimento" ou "política industrial". "Em ambos os países, as necessárias 'obras públicas' de Adam Smith passaram a incluir maciços programas de faróis, estradas, canais e ferrovias" (MURPHY, 2014, p. 60) que constituíram o desenvolvimento da infraestrutura de transportes e comunicação para integrar o país.

O caso do Japão não é diferente. Notável foi o empenho japonês para o desenvolvimento da empresa automobilística Toyota é abordado no livro "Bad 
Samaritans" no qual Chang (2007, p. 2) afirma que o governo japonês expulsou a General Motors e a Ford em 1939 e financiou, através do Banco do Japão, a estruturação e desenvolvimento da Toyota. Para o autor, caso o governo japonês tivesse aderido ao pensamento do livre mercado, tão promovido a partir dos anos 1960, ou tivesse optado pela hipótese de abertura aos investimentos estrangeiros (FDI $=$ Foreign Direct Investments) a Toyota não existiria hoje (CHANG, 2007, p. 3, 77). Chang (2007, p. 198) aponta que levaram mais de trinta anos de subsídios e proteção para que a empresa japonesa se tornasse competitiva no mercado automobilístico internacional.

O papel do Estado, portanto, segundo Chang $(2004,2007)$ foi fundamental no desenvolvimento da indústria nacional nos países hoje considerados desenvolvidos como os Estados Unidos, os países da Europa Ocidental e o Japão.

Esse inegável papel do Estado levaram os países que se encontravam em atraso a buscarem políticas públicas visando o desenvolvimento.

Mesmo autores considerados mais à direita do espectro político, portanto de vieses mais liberais do ponto de vista da economia, não negam a importância do Estado. Antonio Delfim Netto (2018), por exemplo, em artigo publicado no Jornal Folha de São Paulo, destacando que estamos passando por uma "quarta revolução industrial" em que se incorpora à indústria as novas tecnologias da informação e da inteligência artificial, afirma que "Nos países preocupados com o problema (Alemanha, China, Coreia do Sul, Inglaterra, França e EUA) aprendeu-se que tal ruptura da 'filosofia produtiva' dificilmente poderá ser feita sem o suporte de uma política industrial bem construída pelo Estado”.

Leslie Sklair (2000), entende que o mundo hoje é comandado por uma classe capitalista transnacional que tem no discurso da globalização o direcionamento de seus interesses. Para Sklair (2000) essa classe se serve de parcerias com órgãos do estado, através de políticos e burocratas para implementação de um ambiente globalizador nos países, implementando o que chama de "práticas transnacionais". Embora afirmando que sua concepção de globalização rejeita o entendimento de que o comando da economia mundial se encontre centrado em mãos do estado (realismo) ou no globalismo (o fim do estado), afirma que existe um sistema global baseado nessas práticas transnacionais que cruzam as fronteiras, mas que não se origina das agências estatais ou de seus atores. Para ela, essas práticas “opera em três esferas, a econômica, a política e a cultural ideológica. O total é o sistema global" (SKLAIR, 2000, p. 1). 
Ainda que entenda que o poder esteja fora do estado, não nega que a classe capitalista transnacional opere dentro do político (através do que chama de políticos e burocratas globalizadores), o que equivale dizer, neste contexto, dentro ou a partir do estado. Ela cita o exemplo da Austrália e do Brasil, onde agências como Inmetro e o Instituto Nacional de Padronizações (ABNT ?) atuariam na conformidade dos interesses dessa classe globalizante.

Mariana Mazzucato (2014) demonstra como as todas as grandes inovações da indústria, especialmente as das áreas estratégicas, sempre tiveram o estado nacional financiando as pesquisas e fomentando a fase inicial das empresas, uma vez que nenhuma empresa da iniciativa privada possui o capital necessário e nem assume o risco de investir em áreas novas que ainda não estejam comercialmente estabelecidas. No caso dos Estados Unidos, Mazzucato (2014) aponta a existência de quatro agências voltadas para esse fomento, a Darpa (Agência de Projetos de Pesquisa Avançada de Defesa, de 1980); a Sbir (Programa de Pesquisa para a inovação em pequenas empresas, 1982), o Orphan Drug Act, (Lei de Financiamento de Drogas para Doenças Raras, 1983) e a National Nanotechnology Initiative (Iniciativa Nacional para a Nanotecnologia, 2001). A Sbir foi, por exemplo, a agência que deu apoio e financiamento à Apple para o desenvolvimento do i-phone, afirmando Mazzucato que: "De fato, não há uma única tecnologia significativa por trás do i-phone que não tenha sido financiada pelo Estado" (2014, p. 36).

Exemplo claro de que, no tema aqui pesquisado, estado nacional e empresas privadas com sede em seus territórios possuem políticas comuns e ações conjuntas em que o primeiro colabora com o fortalecimento e desempenho das segundas pode ser observado pelo modo de trabalho das agências de propriedade intelectual dos respectivos países. O website do escritório norte-americano de marcas e patentes (órgão estatal) informa que possui um escritório em Alexandria, no estado da Virginia, e sucursais em Beijing, Guangzhou e Shangai, na China, com equipes de advogados e técnicos para auxiliar as empresas americanas em operação ou que queiram operar na $\mathrm{China}^{73}$.

Na China, o papel do Estado no desenvolvimento econômico e social é notório. Se hoje os maiores patenteadores na China são empresas privadas (tabela 16), há apenas 8 anos dentre seus dez maiores patenteadores, três eram institutos de ensino (tabela 17).

\footnotetext{
${ }^{73}$ Disponível em: https://www.uspto.gov/patents-getting-started/international-protection/intellectualproperty-rights-overseastoolkits/ip. Acesso em: 20/09/2018.
} 
Tabela 16 - Principais requerentes de patentes na China no sistema PCT (Tratado de Cooperação de Patentes - Genebra) e o número de pedidos de registros de patentes nos anos de 2018 e 2019

\begin{tabular}{l|l|l}
\hline Requerente & 2018 & 2019 \\
\hline Huawei Technologies Co. Ltd. & 5.405 & 4.411 \\
\hline Guang Dong Oppo Mobile Telecomunications Corp. Ltd. & 1.042 & 1.927 \\
\hline Boe Technology Group Co. Ltd. & 1.813 & 1.864 \\
\hline Ping Na Technology (Shenzhen) Co. Ltd. & 336 & 1.691 \\
\hline ZTE Corporation & 2.080 & 1.085 \\
\hline SZ DJI Technology Co. Ltd. & 722 & 874 \\
\hline Alibaba Group Holding Limited & 335 & 846 \\
\hline Shenzhen China Star Optoelectronics semicondutor & 567 & 603 \\
Display & 179 & 506 \\
\hline Vivo Mobile Communication Co. Ltd. & & \\
\hline Wuhan China Star Optoelectronics Semiconductor & & \\
Display Technology Co. Ltd. & & \\
\hline
\end{tabular}

Fonte: Organização Mundial da Propriedade Intelectual

Tabela 17 - Principais requerentes de patente na China no sistema PCT (Ano de publicação $=2012)^{74}$

\begin{tabular}{l|l|l}
\hline Applicant / Requerente & Publication & Ranking \\
\hline ZTE Corporation & 3.906 & 1 \\
\hline Huawei Technologies Co. Ltda & 1.801 & 4 \\
\hline Shenzhen China Star Optoelectronics Technology Co.,Ltd. & 204 & 78 \\
\hline Huawei Device Co., Ltd & 200 & 80 \\
\hline China Academy of Telecommunications Technologies & 171 & 101 \\
\hline Institute of Microelectronics of Chinese Academy of & 161 & 108 \\
\hline Sciences & & \\
\hline Tencent Technology (Shenzhen) Company Limited & 122 & 146 \\
\hline Hunan Sany Intelligent Control Equipment Co.,Ltd & 94 & 202 \\
\hline Peking University & 92 & \\
\hline Da Tang Mobile Communications Equipment Co., Ltd & 82 & 208 \\
\hline
\end{tabular}

Fonte: Organização Mundial da Propriedade Intelectual

\footnotetext{
${ }^{74}$ Esses dados não mais se encontram disponíveis no site da Organização Mundial da Propriedade Intelectual e tomamos de nossa dissertação de mestrado apresentado no ano de 2015.
} 
E não são apenas os institutos de pesquisas públicos e universidades que recebem o apoio governamental, em políticas de estado. A cidade de Hangzhou, que se transforma rapidamente no centro tecnológico do país, é um exemplo privilegiado do importante papel do estado no desenvolvimento.

Para Geromel (2019, p. 72) "governos apoiam empresas de tecnologias gigantes e já estabelecidas - lembre que os governos locais dos Estados Unidos facilitaram para fábrica da Tesla e os armazéns/escritório da Amazon; e no Brasil, temos a Zona Franca de Manaus".

Prossegue Geromel: "Em Hangzhou, um dos focos principais é startups" (2019, p. 72”. E “A cidade construiu a Dream Town, região de 3 mil quilômetros e local utópico para empreendedores" e "a cidade de Hangzhou inaugurou a AI Town (cidade da inteligência artificial", no coração da Future Technology City (cidade de tecnologia do futuro), próxima ao Dream Town e à renomada Universidade Zhejiang.

E, finalmente:

"O governo de Zhejiang, Província da qual Hangzhou é a Capital, promete investir mais de 500 milhões de RMB (cerca de 250 bilhões de reais) em 100 centros de inovação como a AI Town e Dream Town, para transformar a região em líder na inovação e atrair os melhores empreendedores de startups da China e do mundo. Algumas das outras faraônica já construídas e em funcionamento: E-Fashion Town (cidade da e-moda), Autonomus Vehicle Town (cidades dos veículos autônomos), Mobile Gaming Town (cidade dos jogos para dispositivos móveis), IoT Town (cidade da internet das coisas)" (GEROMEL, 2019, p. 73).

Ou seja, como se demonstrou no exemplo de desenvolvimento dos Estados Unidos, dos demais países europeus que protagonizaram as primeiras revoluções industriais, o Japão e a Coréia do Sul ou dos países ainda em desenvolvimento que conheceram surtos de desenvolvimento, também a China passa pelo processo de catching up pela ação do estado diretamente e pelas empresas privadas com capital estatal e fortemente amparados por políticas públicas. O Estado se mostra fundamental em qualquer processo de industrialização e desenvolvimento econômico social, inexistindo na história qualquer processo de desenvolvimento que pudesse ter origem espontânea ou basicamente sustentada unicamente pelo "mercado". 


\section{Capítulo 14}

\section{Um Mundo Bipolar}

A ascensão chinesa, acompanhada da intensificação do comércio internacional e consequente abertura para as tecnologias e para as marcas ocidentais é um processo que tem seu incremento observado nos anos 1980, conforme relatou Wladimir Pomar após várias viagens à China no período, portanto sob o regime de Deng Xiaoping:

Os estilos ocidentais de publicidade, de vestir e de comerciar são aceitos e admirados. Supermercados modernos aparecem nas grandes cidades. Estradas e ruas estão cobertas de outdoors de bens de consumo, em lugar dos antigos e tradicionais slogans da propaganda marxista, que a imprensa ocidental considera maçantes e ineficazes.

A mesma fotografia, mostrando um camponês passando com sua bicicleta sob um painel da Coca-Cola, é repetida à exaustão, como se a China toda fosse essa mesma e nova imagem. (POMAR, 1987, p. 14).

Para Marcos Troyjo (2016) vivemos hoje uma cena em que há vários vetores “desglobalizantes" "75. Em oposição ao cenário do início dos anos 1990 quando o Japão liderava a ascensão econômica da Ásia, a China agora é que está na liderança.

Giovanni Arrighi (2007) também entendia que estávamos presenciando uma ascensão chinesa, e para o autor italiano, haveremos de ter uma configuração mundial com uma roupagem um pouco diferente. Para Arrighi (2007, p. 23-24) "As consequências da ascensão da China são grandiosas" e "mais provável do que nunca, nos dois séculos e meio desde a publicação de A riqueza das nações, a concretização da ideia de Smith de uma sociedade mundial de mercado baseada em uma maior igualdade entre as civilizações".

Alguns autores viram na eleição de Donald Trump nos Estados Unidos em 2016 e no Brexit, a saída da Grã-Bretanha na União Européia por referendum em 2016 como sinais de freio ou mesmo reversão no processo de globalização. Yuval Noah Harari (2018) assevera que os eleitores que votaram neste sentido ainda acreditam no

\footnotetext{
${ }^{75}$ Além da ascensão da China, os outros três vetores, em oposição à globalização dos anos 1990, apontados pelo autor são (a) os conflitos e tensões multiplataformas em oposição ao fim da história com a consolidação da democracia e do livre mercado; (b) os Estados Unidos assolados por uma onda isolacionista em oposição à condição de hiperpotência e (d) o estancamento das dinâmicas de integração regional e ressurgimento do Estado-nação como protagonista em oposição à orientação em torno de blocos econômicos.
} 
"pacote liberal", mas entendem que ele deve ir apenas até a fronteira. Já a China estaria, na visão do autor, mais afinada com o liberalismo em escala mundial, em contraposição ao que aconteceria em partes do Ocidente. Para Harari:

\begin{abstract}
"A China, superpotência em ascensão, apresenta uma imagem quase invertida. É cautelosa na liberalização de sua política doméstica, mas adotou uma abordagem muito mais liberal em relação ao resto do mundo. Quando se trata de livre mercado e cooperação internacional, Xi Jiping parece ser o verdadeiro sucessor de Obama. Tendo posto o marxismo-leninismo em segundo plano, a China parece estar bem feliz com a ordem liberal internacional" (HARARI, 2018, p. 31).
\end{abstract}

Em que pese ser comum explicações baseadas em um suposto liberalismo, mesmo quando relacionados à China, como também faz Arrighi (2007, p. 23-24), outras explicações se colocam, como a de Wallerstein (2001), para quem a economia mundial tem uma integração oriunda já nos primórdios do capitalismo e seu funcionamento não pode ser analisado separadamente. Para o autor há um processo a partir de um sistema mundo europeu, entendido como sistema porque a economia ultrapassava as unidades políticas e europeu porque ainda não tinha atingido a totalidade dos lugares, que avança e passa a integrar as outras regiões do mundo, sob uma lógica de divisão mundial do trabalho.

Na ótica de um sistema mundo, a ascensão da China se daria dentro de um quadro que, do ponto de vista econômico, não haveria de trazer grandes mudanças, tratando-se de mais um poder que ascende nesse sistema, como os Estados Unidos, e em algum sentido, como o Japão e a Coréia do Sul mais recentemente. A sua adesão à Organização Mundial do Comércio em 2001 faz presumir sua subjunção às regras desse sistema mundial. À Organização Mundial da Propriedade Intelectual a China já havia aderido em 3 de março de 1980.

Madeleine Albright (ALBRIGHT, 2003, p. 548), então Secretária de Estado dos Estados Unidos, equivalente ao ministro de relações internacionais, relata em sua biografia que visitou a China por cinco vezes, com várias pautas, e que "O sucesso mais tangível da estratégia da administração de engajamento da China foi o acordo de 1999, negociado pelo tenaz representante do Comércio dos Estados Unidos, Charlene 
Barshefsky, de pavimentar a entrada da China na Organização Mundial do Comércio" "76, lembrando que isso fazia com que a China passasse a se regular por normas internacionais.

Kissinger, que afirma ter visitado a China mais de cinquenta vezes, também reconhece $\log o$ na introdução de seu livro que "Nem sempre concordei com a perspectiva chinesa, assim como nem todo leitor vai concordar. Mas é necessário compreendê-la, uma vez que a China vai desempenhar esse papel tão importante no mundo que está emergindo no século XXI” (KISSINGER, 2011, p. 7).

Estamos a suscitar que um dos mecanismos para as hegemonias econômicas hoje no mundo se aprofunda com o uso das propriedades intelectuais das quais a marca empresarial e a patente de invenção são seus mais importantes instrumentos. Conforme nossa digressão sobre o aspecto semiológico da marca e da forma como ela se efetiva na mente e nas emoções das pessoas através da linguagem e da comunicação visual, não se pode deixar de fazer alguma incursão sobre o sentido de uma eventual nova hegemonia de marcas de um país não ocidental. As marcas, eminentemente visuais, trazem outros signos e outros significados, oriundos da cultura chinesa, e o questionamento se faz se essa nova hegemonia traz alguma mudança no modo de ver e ler o mundo.

Deve-se inicialmente questionar se a ascensão do Japão ou da Coréia do Sul representou alguma mudança com suas marcas conhecidas como Sony, Toyota, Hyundai, ou Samsung. Insta destacar que o Japão abriu seu mercado e promoveu um processo de ocidentalização a partir de 1870, no que ficou conhecido como “Restauração Meiji”. No mais, tanto Japão como a Coréia do Sul não chegaram a ameaçar a hegemonia americana tendo em vista outros fatores como tamanho de território, população, forças armadas, etc, embora haja tido preocupação por parte dos Estados Unidos em relação ao avanço tecnológico do Japão (HARVEY, 2010, p. 35). Observamos aqui que nem o Japão e nem a Coréia do Sul possuem um território continental como a China, aspecto hoje que recebe especial atenção daqueles que procuram compreender a ascensão chinesa (ROSENTHAL; WONG, 2011).

Ao abordar este tema não podemos fazer sob uma ótica dicotômica do mundo, entre Ocidente e Oriente, de quem procura firmar a sua identidade a partir da tipificação,

\footnotetext{
${ }^{76} \mathrm{Em}$ tradução do autor. No original: The most tangible success of the administration's engagement strategy was the 1999 agreeement, negotiate by our tenacious U.S. Trade Representative Charlene Barshesky, clearing the way for China's entry into the World Trade Organization (WTO).
} 
ou mais propriamente através de um processo de olhar o outro como alienígena ou exótico, o que o diminuiria, como denuncia Edward Said em "Orientalismo". Embora mais voltada para a análise dos discursos presentes na literatura europeia voltada para o Oriente mais próximo, a ilações de Said (2007) são extensivas a toda a área que a Europa inicialmente, e os Estados Unidos em seguida, determinou como "à leste". Na introdução da obra Edward Said afirma que:

"Comecei com a suposição de que o Oriente não é um fato inerte da natureza. Ele não está meramente ali, assim como o próprio Ocidente tampouco está apenas ali. Devemos levar a sério a grande observação de Vico de que os homens fazem a sua história, de que só podem conhecer o que eles mesmos fizeram, e estendê-la à geografia: como entidades geográficas e culturais - para não falar de entidades históricas -, tais lugares, regiões, setores geográficos, como o "Oriente" e o "Ocidente" são criados pelo homem (SAID, 2007, p. 31).

Ao relatar como a força de uma tradição tão enraizada na mente de pesquisadores tem o "Oriente", Said afirma que:

"O resultado para o Orientalismo tem sido uma espécie de consenso: certas coisas, certos tipos de afirmação, certos tipos de obra parecem corretos ao orientalista. Ele constrói a sua obra e pesquisa com base nessas coisas, e elas, por sua vez, exercem forte pressão sobre os novos escritores e eruditos. Assim, o Orientalismo pode ser considerado um modo de escrita, visão e estudo regularizados (ou orientalizados), dominados por imperativos, perspectivas e vieses ideológicos ostensivamente adequados para o Oriente. O Oriente é ensinado, pesquisado, administrado e comentado segundo maneiras determinadas" (SAID, 2007, p. 275).

No Brasil, o debate sobre a China e sua ascensão econômica se pauta principalmente em uma literatura ocidental, marcada ainda pelos preconceitos de um certo "orientalismo" que parte de valores ocidentais como democracia e liberalismo econômico, e negligenciam a importância de fatores como planejamento estatal ou, como tem denominado Elias Jabbour, uma "Nova Economia do Projetamento" (JABBOUR, 2020), bem como modos de organização como os comitês de bairro, que foram fundamentais, por exemplo, no combate recente à pandemia, e que se constituem em instrumentos eficazes de desenvolvimento. 
Baudrillard (1991, p. 8) no ano de 1981 sustentou que vivemos em um mundo em que o real não mais existe. A simulação é o próprio real, ou o hiper-real, em uma abstração total da realidade. "O território já não precede o mapa, nem lhe sobrevive. É agora o mapa que precede o território - precessão dos simulacros - é ele que engendra o território cujos fragmentos apodrecem lentamente sobre a extensão do mapa". Para os operadores da Geografia, este pensamento não deve se sustentar. Partimos, obviamente, do real, do território, mas trata-se de uma abordagem que pode nos interessar como uma abordagem que explica parte do jogo de narrativas que se criam em face de um notável fenômeno que é a ascensão da China.

Neste jogo das "aparências simuladas" o que muda no mundo dominado pelas imagens a ascensão da China como potência econômica em todo o mundo? A depender de possíveis leituras da obra de Baudrillard, observamos que a partir de um acontecimento no ano de 1975 há indícios de que a China compreende a importância dos signos e das representações semióticas do mundo moderno, de uma eventual necessidade de ajuste e participação nesse mundo de simulacros através da oposição simulada (calculada, medida), a fim de possibilitar a coexistência econômica e política. Esse acontecimento foi a adoção a prazo do alfabeto romano e a supressão gradual e parcial de sua escrita ideográfica.

"Este último significa a indiferenciação 〈orbital» de um sistema de
signos abstrato e modelizado, na órbita do qual se vão reabsorver todas
as formas, outrora singulares, do estilo e da escrita. Satelização da
língua: é a maneira de os chineses entrarem no sistema de coexistência
pacífica, o qual se inscreve no seu céu justamente ao mesmo tempo pela
junção dos dois satélites. Voo orbital dos dois grandes, neutralização e
homogeneização de todos os outros no solo" (BAUDRILLARD, 1991,
p. 51).

Importante destacar nesta ascensão chinesa e a constituição de um mundo bipolar a intensa e constante internacionalização da economia chinesa. A presença chinesa na África e na América Latina são notórias. E até mesmo nos Estados Unidos, onde a China investiu 46,5 bilhões em $2017^{77}$. Empresas estatais chinesas adquirem cada vez mais participações ou até mesmo $100 \%$ das ações de empresas privadas americanas

77 Jornal Clarín em português. Disponível em: https://www.clarin.com/clarin-emportugues/destaque/china-maior-investidor-unidos_0_S1uhrODP1.html. Acesso em 03/07/2018. 
inclusive empresas estratégicas como de alta tecnologia, aeroespaciais e principalmente de energia ${ }^{78}$.

O fato da presença das empresas chinesas nos Estados Unidos e na Europa cria uma grande preocupação nas empresas desses lugares centrais da economia mundial.

$\mathrm{Na}$ primeira parte do trabalho fizemos uma abordagem do aspecto semiótico da marca empresarial como signo distintivo figurativo ou literal. No caso da literalidade observa-se que nem sempre a tradução de uma marca será possível para o idioma chinês, nas hipóteses em que inexiste uma palavra, um carácter na língua local (ideograma). A União Europeia, em guia para o investidor europeu na China, recomenda que nessa hipótese a empresa europeia adote uma marca com correspondência (nome) local, ou os consumidores irão inventar um. A adoção da marca local poderá ser uma tradução literal da marca original, uma versão fonética da marca, ou uma combinação de versão literal e fonética. O guia observa que não apenas o sentido, mas o som e o tom são importantes e podem afetar a reputação da marca ${ }^{79}$. A recomendação assim é que se registre duas marcas, a original e a criada para o mercado local ${ }^{80}$.

A China é um país continental, com população superior a um bilhão e trezentos mil habitantes. Nos inúmeros estudos que buscam compreender a ascensão chinesa, principalmente naqueles realizados na Europa, o espaço geográfico tem sido cada vez mais reconhecido como fator a ser melhor entendido. Destacando a relevância do Brasil, Índia, China e Rússia na economia mundial, Rosenthal e Wong (2011) reconhecem "a importância da escala geográfica para o crescimento econômico".

No sentido inverso, a China não está menos atenta à questão das marcas e de seus simbolismos. Interessante destacar que algumas empresas chinesas, dado o histórico preconceito do "Made in China", escondem, ou pelo menos são discretas na divulgação da nacionalidade junto a suas marcas. A Lenovo e a Haier são dois notórios exemplos. A Lenovo (Lenovo Group Ltd ou Lenovo PC International) é uma empresa chinesa de tecnologia, fundada em 1984 por Liu Chuanzhi em Pequim, mas com uma de suas sedes hoje em Hong Kong, e a outra estabelecida na Carolina do Norte nos Estados Unidos.

\footnotetext{
78 Site da CNN. Disponível em : https://money.cnn.com/interactive/economy/chinese-acquisitions-uscompanies/. Acesso em 03/07/2018.

${ }^{79}$ http://www.china-iprhelpdesk.eu/sites/china-hd/files/public/Mainland_china.pdf

${ }^{80}$ Obsserva-se, porém, que a marca com o ideograma chinês não é registrável no Protocolo (Tratado) de Madri.
} 
Operando em mais de 180 países, é uma das 500 maiores empresas do mundo, avaliada em 50 bilhões de dólares americanos, com mais de 63 mil empregados ${ }^{81}$.

Já a Haier (Haier Group Corporation) é uma multinacional de utilidades domésticas e produtos eletrônicos, com sede em Qingdao, na Província de Shandong. Apresenta-se com seis marcas de grande alcance, Haier, Casarte, Leader, GE Appliances, Fisher\&Paykel, Aqua e Candy. A Companhia tem uma longa história iniciada como fabricante de refrigeradores em 1920 em Qingdao, incorporada ao Estado em 1949. Em 1984 foi refundada como Qingdao Refrigerator Co, passando depois por uma etapa de joint ventures com a alemã Liebherr. A partir dos anos 1990 iniciou seu processo de expansão internacional abrindo operações na Indonésia e Filipinas. Hoje também listada entre as 500 maiores empresas do mundo, de capital estatal e privado, eminentemente chinês e um percentual do Banco da China e de fundos de investimentos $(1,47 \%)^{82}$.

Difícil ignorar assim que a China é uma potência real que já há algum tempo apresenta índices econômicos que a colocam ao lado dos norte-americanos, já ultrapassou o Japão, a Coréia do Sul e Alemanha, e deixam para trás outras potências europeias e dos Brics. Olhar a China e entender seu papel no mundo de hoje e do futuro é um enorme desafio, em que não se poderá cair em vieses antigos, sob pena de mal compreendê-la.

Ao apregoar no início dos anos 1990 que se vislumbrava um choque de civilizações entre o Ocidente e o Oriente (e colocava que havia ainda também aos valores ocidentais a ameaça do Islã), Huntington afirmava que se a China mantivesse seus índices de crescimento até então verificados nos últimos anos, se mantive a unidade de toda a nação.

\footnotetext{
${ }^{81}$ Informações disponíveis em: https://investor.lenovo.com/en/global/home.php. Acesso em 05/12/2020.

${ }^{82}$ Informações disponíveis em: http://smart-home.haier.com/en/gpxx/. Acesso em 05/12/2020.
} 


\section{Capítulo 15}

\section{O Estado da Arte e da Técnica na corrida rumo à hegemonia}

A hoje moderna cidade de Hangzhou é a capital da Província de Zhejiang, considerada pelos chineses um dos locais de nascimento da civilização chinesa, o "Paraíso na Terra" e uma das sete capitais antigas do país, situada a leste, próximo ao Rio Qiantang e o Grande Canal, a uma hora de trem de Xangai, se utilizado o trem de alta velocidade. Vários tipos de chá são produzidos na província e em particular nos arredores da capital. O chá verde "Longjing", ranqueado como o $1^{\circ}$ chá dentre os 10 melhores da China, é cultivado na região há 1.200 anos. A região, como toda a costa litorânea do leste, é uma região hoje rica e desenvolvida. Em Zhejiang, o setor secundário, a indústria propriamente dita, respondia por $62,6 \%$ da economia e o setor primário por $2,5 \%^{83} \mathrm{em} 2017$, segundo dados do governo chinês. Na agricultura, se destacam também os grãos como um de suas principais produções, em que se alcança o índice de 80,7 de mecanização.

Ao visitante estrangeiro chama a atenção, tradicionalmente, a milenar cultura do chá. Em artigo que trata da inovação e competição na China, o Advogado e especialista em Tecnologia Ronaldo Lemos relata que:

[...] fica claro como a digitalização mudou até práticas milenares. A filha de uma das famílias produtoras locais acabou se mudando para a Austrália, desencantada com as perspectivas do cultivo do chá. No entanto, em razão do processo de digitalização do país, com celulares e conexão barata em toda parte, enxergou uma oportunidade. E se fosse possível criar uma plataforma digital para vender o chá cultivado localmente para outras localidades? Foi exatamente o que ela fez. Mudou-se de volta e transformou o cultivo da família (...). Em quatro anos, a região saltou de um faturamento de US\$500 mil anuais para US\$ 20 milhões. Mesmo quem mora em Pequim, a 1.400 quilômetros de Hangzhou pode comprar o chá da região e recebê-lo em 24 horas" (LEMOS. 2019, p. A22).

Segundo dados do próprio governo a economia da informação lidera a transformação econômica e o incremento dos processos na Província, efetivando valores agregados de 321,6 bilhões de yuan, aumento de $21,8 \%$ e contribuindo com mais de $50 \%$ para o crescimento do produto interno bruto. O comércio eletrônico, a internet móvel e os setores de conteúdo digital tiveram crescimento em 2017, respectivamente, de $36,6 \%$,

\footnotetext{
${ }^{83}$ Disponível em: http://eng.hangzhou.gov.cn/art/2018/1/10/art_1450889_105.html. Acesso em $15 / 12 / 2020$.
} 
$35,0 \%$ e $28,5 \%$. Ao setor privado é atribuída essa grande vitalidade, que contribui com $60,2 \%$ do produto interno bruto e 44 das empresas locais estão entre as 500 maiores companhias da China ${ }^{84}$.

Trata-se da otimização da produção com o mais avançado das tecnologias a produtos protegidos por propriedade intelectual. A proteção jurídica das indicações geográficas é uma proteção do "modo de cultivar" acrescentado das características geográficas da área de produção, do terroir, cujas denominações não podem ser copiadas em outros lugares. O chá, como o arroz chinês e o gengibre, são importantes indicações geográficas protegidas internacionalmente. Lembramos ainda que sobre os produtos agrícolas recaem outra proteção de propriedade intelectual que é a já mencionada “cultivares de plantas", uma proteção de espécie patentária sobre os aprimoramento de sementes e plantas desenvolvidas pelo homem.

Mas o que chama a atenção hoje dos estrangeiros é que a cidade se transforma rapidamente no centro tecnológico do país. É a cidade sede da gigante da internet Alibaba, e cidade em terceiro lugar na China, e sexta no mundo em quantidade do que o setor empresarial chama de "unicórnio" (atrás de Pequim e Xangai). Unicórnios são as empresas iniciantes de tecnologia (startups) que atingiram o valor de mercado superior a 1 bilhão de dólares norte-americanos. Pequim tinha, em 2020, 93 unicórnios, seguida de São Francisco (68), Nova York (33), Shenzhen e Hangzhou com 20 cada $^{85}$.

Ainda em Hangzhou, sede de uma das mais prestigiosas universidades do país (Universidade de Zhejiang) o governo deu início à AI Town, cidade da inteligência artificial), onde se fazem investimentos pesados no financiamento de projetos e empresas de tecnologia. Apenas o governo provincial de Zhejiang deve investir cerca de 250 bilhões de reais em centros de inovação (GEROMEL, 2019, p. 73).

É interessante notar que esse desenvolvimento chinês no estado da técnica e da arte se deu notadamente a partir dos anos 1970, quando no Ocidente se encerrou o período de ouro da economia a que chamam de os "Trinta Gloriosos" do Pós-Segunda Guerra. No campo das propriedades intelectuais esse desenvolvimento se acentua a partir dos anos 2000, quando a China se torna membro da Organização Mundial do Comércio (2002/2003). Como ao se tornar membro uma proteção mínima de direitos da propriedade

\footnotetext{
84 Disponível em: http://eng.hangzhou.gov.cn/art/2018/1/10/art_1450889_105.html. Acesso em $15 / 12 / 2020$.

${ }^{85}$ Disponível em:

https://www.bworldonline.com/us-china-lead-number-of-unicorns-in-global-unicorn-index-2020/. Acesso em 26/12/2020.
} 
intelectual se faz impositivo, não é despropositado afirmar que por volta desses anos a China já possuía um parque industrial que se desenvolvia a partir de suas próprias tecnologias ou, explicitamente, já tinha alcançado um estágio de catching up relativamente bem avançado.

Dani Rodrick (1997, p. 2) afirmava nos finais dos anos 1990 que a globalização estava indo longe demais, atingindo instituições tradicionais de países como o Japão, que deixava para trás a tradição do emprego da vida toda, como a Alemanha com o corte de direitos previdenciários, com greves na Coréia do Sul e competição desenfreada na América Latina. Afirmava que o processo de globalização expunha fraturas entre aqueles que tinham qualificações para o mercado global e aqueles que não estavam aptos para mercados desregulados. O autor argumentava então que o maior desafio da economia mundial seria compatibilizar a globalização com a estabilidade política e social interna dos países.

Vinte anos depois o mesmo autor afirma agora ocorrer um renascimento da política industrial como ação imperativa dos países (RODRIK, 2020), nos países em desenvolvimento em virtude de uma reação aos ditames do Consenso de Washington, na zona do euro em virtude dos fracos crescimentos econômicos, nos Estados Unidos e nos países da Europa Ocidental, pela perda dos empregos industriais e a emergência da China como grande competidora. "O interesse na política industrial tem sido estimulada pelas mudanças disruptivas da tecnologia - da automatização para digitalização, indústria 4.0, e a Internet das Coisas" (RODRIK, 2020, p. 2).

Em recente entrevista, após o susto causado pela pandemia do coronavírus, em agosto de 2020, respondendo a questionamento sobre diminuição da globalização em virtude da crise do Covid19, Rodrik afirma que os indicadores mostram uma forte queda, que não se sabe o tempo que levará para se recuperar. Mas que desde a crise financeira de 2008, tendências de queda no comércio e nas cadeias globais já estavam se estabelecendo. Tendências estas que afastam do processo que ele denomina de "hiperglobalização". Para ele, ao contrário da livre circulação de bens, serviços, capital e finanças, nunca houve regime internacional de liberalização progressiva de circulação de pessoas, e que a restrição deve aumentar em virtude das questões de saúde. Para Rodrik, o tipo de globalização havida desde os anos 1990 foi de um tipo que restringia cada vez mais as capacidades dos governos nas economias domésticas e que agora será necessário "alcançar um equilíbrio entre os ditames de uma economia mundial aberta e as 
preferências de diferentes nações para conduzir seus modelos econômicos e sociais" (RODRIK, 2020).

Ao colher dados da China, é claramente perceptível que não ter seguido regras liberais do Consenso foi não apenas positivo, mas imperativo para o desenvolvimento chinês, que optou por um caminho planejado, organizado, sustentado, a que Jabbour (2020) denomina de Nova Economia do Projetamento.

Sobre a globalização, aliás, relembrando que nos anos finais do Século XIX, com o padrão ouro, um tipo de globalização também ocorreu, com intensa trocas comerciais entre os países, possibilitadas pelas construções de ferrovias, aquela foi um tipo de globalização diferente em que não havia restrições de migrações, de modo que a movimentação de pessoas e de capital era mais próxima do que a atual em que se movimenta o capital mas não a mão de obra, também porque não havia tanta competição entre produtos similares, sendo mais uma troca de produtos primários com produtos manufaturados e, o mais importante, os governos não estavam ainda demandados por sistemas de proteção social e seguridade em larga escala (RODRIK, 1997, p. 9).

Vemos hoje também que os países da Europa vão perdendo espaço nos campos das marcas e patentes. Eles resistem ainda em setores tradicionais, como o setor de vestimentas e moda, com grande destaque para Alemanha, França e Itália (ANDAKU, 2016), mas são setores com inovação tecnológica restrita no âmbito do avanço científico global. E mesmo neste campo vão perdendo espaço para os Estados Unidos e os países da Ásia. Entre os países do Brics, as marcas e patentes apresentam crescimento tímido, ou mesmo estagnado, como é o caso do Brasil, exceto o extraordinário avanço da China. A corrida rumo à hegemonia, tendo as propriedades intelectuais como fundamento desta hegemonia está mesmo restrita à competição entre Estados Unidos e China.

Não é possível desconsiderar a Rússia, que é ainda a segunda potência militar do planeta, mas no critério de propriedades intelectuais ela está bem distante de China e Estados Unidos. Estável ao longo da última década, apresentou em 2019 leve queda no número de pedidos de patentes em relação a 2010 (29.711 em 2019 e 32.838 pedidos em 2010). Manteve-se estável no número de patentes concedidas a seus nacionais (20.373 em 2019 e 21.783 em 2010), mas aumentou seu estoque de patentes em vigor (263.688 em 2019 contra 181.904 em 2010 = aumento de $41 \%$ em uma década). Porém, em 
números gerais de patentes (pedidos de registro, concessões de patentes e patentes em vigor) apresentam em torno de $10 \%$ daqueles verificados com China e Estados Unidos) ${ }^{86}$.

A Índia ${ }^{87}$, outro país emergente e membro do Bric, apresenta números ainda mais modestos em todas as categorias de propriedades intelectuais (76.556 patentes em vigor em 2019, contra 47.224 em 2010) o que a torna um país muito parecido com o Brasil.

Um índice de inovação ${ }^{88}$ que não se confunde com os índices que apresentamos objetivamente de marcas e patentes é um denominado "índice de inovação" da mesma Organização Mundial da Propriedade Intelectual, mas que se constitui de critérios que não acreditamos objetivos, tais como "desempenho de instituições" e “estabilidade política”. Neste índice os Estados Unidos ficaram ranqueados em $3^{\circ}$ lugar em 2020 (Suíça e Suécia em $1^{\circ}$ e $2^{\circ}$ ). A China ficou em $11^{\circ}$ lugar (14º lugar em 2019), mas em $1^{\circ}$ lugar entre as economias de produto interno bruto médio (Malásia e Bulgária em $2^{\circ}$ e $3^{\circ}$ ). Relativizamos este índice, porém, porque adota como critérios como acesso a financiamentos, notas sobre sustentabilidade ecológica, notas sobre ambiente político e institucional, o que traz matéria e assuntos controversos que não adentramos no presente trabalho, uma vez que partem de avaliações políticas subjetivas, não raras vezes enviesadas pelos padrões de democracia representativa ocidental. Para o que mede objetivamente a inovação como pesquisa, conhecimento, outputs tecnológicos, a China aparece sempre entre as maiores notas. Partimos desses critérios objetivos pressupondo o poderio econômico, geopolítico e militar a partir do desenvolvimento de um caminho que Milton Santos chama de unicidade técnica em um mundo técnico cientifico e informacional.

Ao demostrar que a China já está à frente dos Estados Unidos no critério de patentes de invenção, à frente do conhecimento técnico, portanto, e com uma economia altamente diversificada, observada pela assombrosa quantidade de marcas empresariais registradas, verificamos o compartilhamento do poder geopolítico mundial em que os Estados Unidos não são mais a única potência hegemônica.

\footnotetext{
${ }^{86}$ Disponível em: https://www.wipo.int/ipstats/en/statistics/country_profile/profile.jsp?code=RU. Acesso em 20/12/2020.

${ }^{87}$ Disponível em: https://www.wipo.int/ipstats/en/statistics/country_profile/profile.jsp?code=IN. Acesso em 20/12/2020.

${ }^{88}$ Disponível em: https://www.wipo.int/edocs/pubdocs/en/wipo_pub_gii_2020.pdf. Acesso em $23 / 12 / 2020$.
} 
Estamos caminhamos para um mundo de hiperconectividade em que temos cada vez mais automação industrial, conexão em tempo real das pessoas em qualquer parte do mundo para qualquer outra parte, cidades inteligentes, vale dizer com semáforos coordenados a melhorar o trânsito de veículos, emergência de sistemas hidráulicos para chuvas, conexão de passageiros e desvios de rotas segundo uma inteligência artificial noticiando em tempo real o transporte público de passageiros, etc, e ela decorre em grande medida do avanço da tecnologia denominada de $5 \mathrm{G}$, também conhecida como Internet das Coisas (IoT - Internet of things).

A empresa dominante nesta tecnologia é a chinesa Huawei, que sofre oposição do governo americano que pressiona outros países a não adotarem a tecnologia da empresa chinesa. No Brasil, o alinhamento do governo Bolsonaro ao governo norteamericano de Donald Trump traz incertezas sobre a implementação da tecnologia chinesa. Recentemente as operadoras de telefonia celular divulgaram comunicado defendendo a empresa chinesa, com o argumento de que eventual restrição atingirá não apenas o desenvolvimento como também a infraestrutura já instalada no país, inclusive das tecnologias $3 \mathrm{G}$ e $4 \mathrm{G}^{89}$.

Para o brasileiro Rodrigo Zaidan, professor de economia na New York University Shangai, os Estados Unidos ainda se manterão na liderança do mundo nas próximas décadas porque são a maior força bélica, concentram os principais centros de pesquisa, são a sede de Facebook, Amazon, Apple, Netflix e Google, que valem muito mais agora após a pandemia, mas principalmente porque nos Estados Unidos os investimentos em pesquisa e desenvolvimento estão situados em $2,8 \%$ do produto interno bruto, enquanto que na China não está ainda em $2 \%$ e porque ainda faltaria à China um salto de qualidade ${ }^{90}$.

Interessante notar que, escrito em agosto de 2020, três meses depois o já mencionado relatório do Departamento de Estado Norte-Americano apontava o projeto "Made in China 2025", iniciativa que desenvolve as empresas campeãs chinesas em 10 áreas decisivas. São elas: “(1) IA, computação quântica e tecnologia da informação de próxima geração; (2) robótica e automação; (3) espacial e aeroespacial; (4) indústria naval

\footnotetext{
${ }^{89}$ Disponível em: https://www1.folha.uol.com.br/mercado/2020/11/teles-saem-em-defesa-de-participacaoda-huawei-no-5g-e-pedem-para-ser-ouvidas-pelo-governo.shtml. Acesso em 14/12/2020. Na versão impressa de 28/11/2020. Página A25 de 28/11/2020.

90 Na versão impressa da Folha de São Paulo de 08/08/2020, página A20. Disponível em: https://www1.folha.uol.com.br/colunas/rodrigo-zeidan/2020/08/eua-ou-china-qual-o-imperio-dofuturo.shtml. Acesso em 21/12/2020.
} 
de alta tecnologia e engenharia oceânica; (5) trem de alta velocidade; (6) eficiência energética; (7) novos materiais; (8) biotecnologia, equipamentos médicos, e farmacêutica avançada; (9) geração de energia e energia de próxima geração e (10) maquinário agrícola" (2020, p.11).

A China tinha em 2018 59,6\% de sua população conectada à internet, tendo mais do que dobrado em dez anos, pois eram apenas 22,6\% em 2008. Ainda abaixo dos Estados Unidos (90\%) e de outros países do Brics (Rússia 76\%, Brasil, 67,5\% e África do Sul 56,2\%, mas acima da Índia 34,5\%), mas tendo se conectado à rede mundial apenas em 1994, como o $77^{a}$ país a fazê-lo, seu crescimento e qualidade na conexão tem sido espantoso $^{91}$. Em números absolutos, porém, é o país com a maior quantidade de pessoas conectadas, com mais de 883 milhões de pessoas conectadas em 2019, a maior parte em conexão de alta velocidade enquanto nos Estados Unidos, em 2019, eram 281 milhões $^{92}$.

A China, além de ter arsenal nuclear, possui pesquisas avançadas na área aeroespacial $^{93}$ e no campo ainda das patentes ultrapassou os Estados Unidos em patentes de inteligência $\operatorname{artificial}^{94}$.

Tatiana Prazeres (2020), bacharel em Direito e Relações Internacionais, Doutora em Direitos Internacionais, a mais jovem Secretária de Comércio Exterior do Brasil, Conselheira Sênior na Organização Mundial do Comércio e professora de Negócios Internacionais e Economia na Universidade de Pequim, ao analisar neste final de 2020 a última década chinesa estabelece quatro aspectos a serem considerados:

"1. A China termina a década muito mais autoconfiante. O ponto de inflexão foi a crise de 2008-09. A partir dali, seus líderes firmaram entendimento de que não precisavam tomar lições do Ocidente a respeito da condução da economia. E dobraram a aposta no modelo 'com características chinesas'(...);

2. A China se tornou mais assertiva no plano externo. Definitivamente ficou para trás o mantra de Deng Xiaoping, segundo o qual o país deveria manter um perfil baixo, esconder suas forças e ganhar tempo.

\footnotetext{
${ }^{91}$ Disponível em: https://chinapower.csis.org/web-connectedness/. Acesso em 25/12/2020.

92 Disponível em: https://www.statista.com/statistics/278417/number-of-internet-users-inchina/\#: : text=The\%20country's\%20internet\%20penetration\%20rate,five\%20Chinese\%20are\%20still\%2 0offline.\&text=Affordable $\% 20$ smartphones $\% 20$ play\%20an\%20important,the $\% 20$ internet $\% 20$ through $\% 2$ 0mobile\%20phones..

${ }_{93}$ Disponível em: Geopolitica_e_o_dominio_aeroespacial_da.pdf. Acesso em 22/12/2020.

94 Disponível em: https://www.tecmundo.com.br/mercado/207475-china-ultrapassa-eua-patentesinteligencia-artificial.htm?fbclid=IwAR2Qo7qcg_ypPIXyH05K-

$\underline{\text { SsxYaHLJaihuntzNdlK0KyPcpLCou_kaLhg53a59ao }}$
} 
O país claramente almeja espaço compatível com o seu peso econômico no mundo. Anunciada em 2013, a Iniciativa do Cinturão e Rota é simbólica das ambições internacionais. A liderança na criação do Banco Asiático de Investimento em Infraestrutura, em 2015, também;

3. No plano interno, aumentou o poder de do Estado sobre a sociedade. O Partido Comunista - e Xi Jiping- se fortaleceram. A década viu uma reforma constitucional para abolir o limite de dois mandatos para o presidente, beneficiando $\mathrm{Xi}$. As políticas para Xinjiang, as novas restrições a Hong Kong e o uso de tecnologia para controle das pessoas e da informação são vistos como emblemáticos de uma China menos liberal.

4. Em toda a década, a China apostou no desenvolvimento tecnológico - para Marcos Caramuru, um dos maiores especialistas em China no Brasil, esse é o principal traço distintivo do período. A China se digitalizou rapidamente, com implicações profundas sobre a economia e a sociedade. A política "Made in China", anunciada em 2015, é um marco das ambições tecnológicas do país. Inteligência Artificial ganhou uma política própria e status de prioridade. (...) sonda pousando na lua, anúncio de computador quântico e o lançamento do BeiDou - o GPS chinês, mais preciso que o GPS (...)" (PRAZERES, 2020, p A10).

Estados Unidos e União Europeia se questionam como será o mundo com a inegável ascensão chinesa e o papel da Organização Mundial do Comércio. Em 2018, o Financial Times reportava, em artigo de Dani Rodrik, sobre a preocupação deles com o comércio mundial com o "poder enorme e crescente da China, que aparentemente joga a globalização com regras diferentes" $" 95$. Os Estados Unidos de Donald Trump optaram pelo enfrentamento. A União Europeia, que embora tivesse a mesma preocupação, foi mais leve e, de fato, chegaram a um acordo sobre investimentos em 30 de dezembro de 2021, conforme informa a página de internet da Comunidade Europeia ${ }^{96}$.

No artigo, Dani Rodrik afirma que Estados Unidos e China partem de pressupostos errados. Que a questão não são as políticas públicas chinesas ou o modo como ela age no regime de comercio mundial. Que o problema é que a Organização Mundial do Comércio foi criada, como outras instituições, com o pressuposto de que as práticas econômicas dos países viriam para uma convergência. Os países não vêm para uma convergência e, portanto, as regras da Organização precisam ser mudadas. Rodrik afirma que não há dúvidas de que a China infringe regras de direitos de propriedade

\footnotetext{
${ }^{95}$ No original "... a large, increasingly powerful country such as China that apparently playsglobalisation by diferente rules". Disponível em https://www.ft.com/content/c2beedfe-964d-11e8-95f8-8640db9060a7. Acesso em 01/01/2021.

${ }^{96}$ Disponível em: https://ec.europa.eu/commission/presscorner/detail/en/IP_20_2541. Acesso em $01 / 01 / 2021$.
} 
intelectual, mas se olharem para sua própria história, Estados Unidos e países europeus verão que utilizaram o mesmo expediente, e encerra o artigo afirmando que a "se a Organização Mundial do Comércio se tornou disfuncional, é porque as regras do comércio internacional já foram longe demais. Um regime de comercio mundial justo deve reconhecer o valor da diversidade nos modelos econômicos. Ele deveria buscar um modo de convivência entre esses modelos, em vez de apertar as regras" ${ }^{\prime 97}$.

${ }^{97}$ Em tradução nossa. No original: “ If the WTO has become dysfuncional, it is because our trade rules have over-reached. A fair world trade regime would recognise the value of diversity in economic models. It should seek a modus vivendi among these models, rather than tighter rules". 


\section{CONSIDERAÇÕES FINAIS}

Partimos da proposição de que as marcas empresariais e as patentes de invenção são potentes medidores da atividade econômica, sendo as primeiras relevantes para a consideração de uma diversidade de oferta de produtos no mercado e as patentes de invenção como um dos índices seguros e razoáveis de inovação tecnológica e de desenvolvimento econômico social, político e militar. Constituem-se de mecanismo de monopólio, concentração de renda e de aprofundamento da desigualdade, que repercute no espaço e em sua reprodução.

A parte do mundo desenvolvida que Huntington (2010) denomina de civilização ocidental, compreendendo a Europa Ocidental mais os Estados Unidos, Canadá, Austrália e Nova Zelândia, continua seu processo de industrialização, em que pese terem exportado parte das produções manufatureiras para os países em desenvolvimento a partir dos anos 1980. Tendo retomado o processo manufatureiro nos últimos 10 ou 15 anos e, em consequência, produzindo inovações, auxiliados pelos investimentos em pesquisa e desenvolvimento, continuam sendo potências industriais, militares e, portanto, econômicas. Mas são sobretudo os Estados Unidos que continuam à frente do bloco ocidental se consideradas as propriedades intelectuais.

A economia mundial volta seu centro dinâmico então para o Pacífico, com inegável avanço de China, Japão e Coréia do Sul. Estes dois últimos com relevantes produções e desempenhos em marcas e patentes, mas com uma notável dianteira da China, que se avoluma em estoque de patentes e amplia o mercado de suas marcas.

Não é despropositado dizer então que a China se destaca nesta segunda década do século XXI como uma nação líder no campo da industrialização e da inovação tecnológica, acompanhada por uma diversificação na oferta de produtos, caracterizada pela quantidade de marcas registradas, inclusive internacionalmente, se colocando ao lado dos Estados Unidos como potência econômica, política e, seguramente caminha como potência militar, ocupando já há algum tempo o $3^{\circ}$ lugar neste item, atrás da Rússia.

Com este desempenho no campo industrial e na inovação tecnológica e das propriedades intelectuais, procuramos observar que a China repete, cem anos depois, a ascensão norte americana, utilizando-se de mecanismos semelhantes, em especial nas políticas a este setor fundamental que é o das propriedades intelectuais, o que poderá lhe dar um protagonismo ao lado dos americanos retirando dos Estados Unidos a condição de potência hegemônica única percebida com a queda do muro de Berlim. 
O que a presente tese procurou demonstrar é que essas potências, Estados Unidos e China, e em menor grau a Europa Ocidental, Japão e Coréia do Sul, formam um centro dinâmico que continuam a ditar as regras em termos de desenvolvimento tecnológico e econômico, não restando aos demais países, quase duas centenas deles, senão caminharem atrás porque não há alternativas diante da unicidade técnica (SANTOS, 1996) homogeneizada para quase toda a extensão do globo terrestre. O enrijecimento dos direitos de propriedade intelectual em geral e o alargamento de proteção conferida às marcas registradas se constituem em instrumento da proteção desse centro dinâmico.

O advento da revolução nas tecnologias eletrônicas e digitais, pela conexão de internet e inteligência artificial faz com que a distância entre os primeiros e os últimos aumentem ainda mais, tendo em vista que a proteção do conhecimento se dá pela proteção da propriedade intelectual, mecanismo jurídico sofisticado que refreia as burlas ao conhecimento como sempre se fez via imitações e engenharias reversas. Exemplos de desenvolvimento como Japão e Coréia do Sul não nos parecem possíveis em caso de submissão aos ditames da propriedade intelectual e a China só obteve êxito em sua ascensão devido ao tamanho de sua economia, poderio enquanto potência militar e por uma política capaz de contornar as restrições impostas pelos tratados internacionais de proteção da propriedade intelectual. Esta a barreira maior a ser vencida pelos países na busca da superação do atraso na fase técnica atual, mecanismo ainda mais eficiente na concentração da renda e da produção da desigualdade pelos royalties.

Lembremos que os países europeus e os Estados Unidos também se desenvolveram a partir do processo das cópias e das imitações, mas em um período em que as legislações de propriedade intelectual não tinham regimes globais.

No mundo atual em que a tecnologia da internet, baseada na conexão 5G, na capacidade infindável de armazenamento de dados em nuvens e na inteligência artificial é dada por poucas empresas desses países centrais, temos que a espacialização dos territórios é configurada a partir desses atores hegemônicos.

Observamos que os processos de desenvolvimento se dão em um planejamento longo, como a invenção do circuito integrado nos Estados Unidos e que é a base da atual revolução tecnológica. Impressiona que 60 anos depois de elaborado o circuito integrado, quando o desenvolvimento ainda ocorre, a China conseguiu se adaptar e fazer um processo de catching up tão rápido, apresentando uma clara dianteira na tecnologia da informação. 
No capítulo destinado aos investimentos estrangeiros diretos observamos que o papel desses investimentos deve ser relativizado, no caso da China, o que demonstra que o crescimento econômico e, o que aqui focamos, o desenvolvimento tecnológico e industrial, é mais resultado do planejamento do Estado, muito mais endógeno, do que simples resultado de investimentos de empresas estrangeiras.

Constituindo em avanço de todo o estado da técnica, avanço da humanidade portanto, as novas inteligências são apropriadas, no Ocidente, pelo setor privado através do direito de patentes, que apropria também dos bens comuns, como a água, levando a ulteriores termos a mercantilização de todo e qualquer bem. No capitalismo, afinal, tudo é mercadoria.

A China desponta como potência neste campo, com uma presença estatal fundamental em seu projeto de potência, alcançando índices econômicos antes do que se previa há 10 ou 15 anos. A pandemia do Covid19 já é um exemplo de como a China é um poder e como o mundo depende cada vez mais dela em muitos setores, tendo se constituído em exemplo de como a resposta a crises, no caso sanitária, só pode ser eficaz se realizada a partir dos agentes estatais e que estejam à frente dos processos de riqueza intelectual fortemente entrelaçada à base material. 


\section{REFERÊNCIAS}

\section{REFERÊNCIAS BIBLIOGRÁFICAS}

AIGINGER, K; RODRIK, Dani. Rebirth of Industrial Policy and an Agenda for the Twenty-First Century. Journal of Industry, Competition and Trade. 2020. Disponível em: $\quad$ https://drodrik.scholar.harvard.edu/publications/rebirth-industrial-policy-andagenda-21st-century. Acesso em 03/09/20.

ALBRIGHT, Madeleine. Madam Secretary. A memoir. With Bill Woodward. Miramax Book. New York. 2003.

ALLEN, Paul. Idea Man: a memoir by the Cofounder of Microsoft. New York. Portfolio Penguin. 2011.

AMSDEN, Alice H. Asia's Next Giant. South Korea and Late Industrialization. New York, Oxford, Oxford University Press. 1992.

ANDAKU, Evandro. Direitos da propriedade intelectual e desenvolvimento desigual. Dissertação de mestrado defendida no Departamento de Geografia da Faculdade de Filosofia, Letras e Ciências Humanas da Universidade de São Paulo. 2016.

ANDREONI, Antonio; GREGORY, Mike. Why and how does Manufacturing still matter: Old Rationalities, New Realitities. In: Revue d'économie industrielle. $N^{\circ} 144$, $4^{\circ}$ trimestre. 2013.

ARRIGHI, Giovanni. A ilusão do desenvolvimento. Tradução Sandra Guardini Teixeira

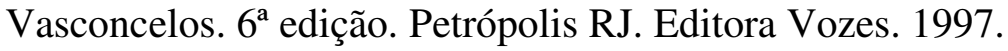

Giovanni. Adam Smith em Pequim. Origens e Fundamentos do Século XXI. Tradução Beatriz Medina. 1ª edição. São Paulo. Boitempo Editorial. 2008.

ARROYO, Maria Monica. Dinâmica Territorial, Circulação e Cidades Médias. In: Eliseu Savério Sposito; Maria Encarnação Beltrão Sposito e Oscar Sobarzo. (Org). Cidades Médias: produção do espaço urbano e regional. $1^{a}$ ed. São Paulo; Expressão Popular, 2006.

AUSTIN, Graeme W. Introduction: the inevitability of "territoriality chalenges" in trademark law. In: Trademark protection and territoriality challenges in a global economy. Irene Calboli e Edward Lee. Edward Elgar Publishing. Cheltenham, UK. Northampton, USA. 2014. 
BADIN, Michelle Ratton Sanchez; BRITO, Adriane Sanctis de; VENTURA, Deisy de Freitas Lima. Direito global e suas alternativas metodológicas: primeiros passos. São Paulo. FGV. 2016.

BARBOSA, Denis Borges. Uma Introdução à Propriedade Intelectual. $2^{\mathrm{a}}$ edição revista e atualizada. Rio de Janeiro. Editora Lumen Juris, 2003.

BAUDRILLARD, Jean. O Sistema dos objetos. São Paulo. Perspectiva. 1993. Jean. Simulacros e Simulação. Lisboa. Editora Relógio d’Agua. Tradução Maria João da Costa Pereira.1991. (Original Éditions Galilée, 1981, Simulacres et simulation).

BENKO, Georges e DUNFORD, Michael. Changement Structurel et Organisation Spatiale du Système Productif. Note de recherche $\mathbf{n}^{\circ}$ 30. 1991. Centre de Recherche sur L’Industrie et L'Amenagement. Institut de Geographie. Université de Paris I.

BRUNHES, Jean. Geografia Humana. Tradução de Ruth Magnanini. Rio de Janeiro. Editora Fundo de Cultura. 1962.

CASTILHO, Ricardo; Samuel Frederico. Espaço Geográfico, Produção e Movimento: Uma Reflexão sobre o conceito de Circuito Espacial Produtivo. In "Sociedade \& Natureza". Uberlândia, 22. Dez. 2010.

CASTRO, Josué. Geografia da Fome: o dilema brasileiro: pão ou aço. Rio de Janeiro. Edições Antares. 1984.

CHANG, Ha Joon; Rowthorn, Robert. The role of the state in economic change. Clarendon Press. Oxford. Oxford University Press. 2001.

Ha Joon. Chutando a escada: a estratégia do desenvolvimento em perspectiva histórica. Tradução Luiz Antonio Oliveira de Araújo. São Paulo. Editora Unesp. 2004.

, Ha Joon. Bad Samaritans: The Myth of Free Trade and the Secret History of Capitalism. Editora Bloomsbury Publishing. 2007

CHESNAIS, François. La mondialisation du Capital. Alternatives économiques. Paris. Syros, 1994.

CHOLLEY, Andre. Observações sobre alguns pontos de vista geográficos. Boletim Geográfico, n. 179. 1964. Conselho Nacional de Geografia. Instituto Brasileiro de Geografia e $\quad$ Estatística. $\quad$ Disponível em http://biblioteca.ibge.gov.br/d_detalhes.php?id=719. Acesso em 17/07/2014.

CHOMSKY, Noam. Quem manda no mundo? Tradução Renato Marques. $1^{\text {a }}$ edição. São Paulo. Editora Planeta. 2017. 
CHOSSUDOVSKY, Michel. A Globalização da Pobreza. Impactos das reformas do FMI e do Banco Mundial. Tradução Marylene Pinto Michel. São Paulo, $1^{a}$ edição, $2^{a}$ impressão. Editora Moderna, 1998.

CLAVAL, Paul. Espacio y poder. Tradución Hugo Martinez Moctezuma. México. Fondo de Cultura Econômica. 1982.

DHAR, Biswajit; JOSEPH, Reji. The Rise of the South and New Paths of Development in the 21 st Century. Foreign Direct Investment, Intellectual Property Rights and Technology Transfer. The North-South and the South-South Dimension. This study was prepared for UNCTAD as a backgroud paper for the ECID Report 2012.

DAVIS, Mike. Planeta Favela. Tradução Beatriz Medina. São Paulo. Boitempo. 2006.

DEBORD, Guy. A Sociedade do Espetáculo. E-book. Tradução de www.terravista.pt/IlhadoMel/1540. eBooksBrasil.com.

FAULCONBRIDGE, James R; BEAVERSTOCK, Jonathan V. Globalization: Interconnected Worlds. Lancaster EPrints. Lancaster University. Depositado em 17.11.2009. Disponível em http://eprints.lancs.ac.uk/28221/. Acesso em 27.07.16.

FARIA. José Eduardo. O Direito na Economia Globalizada. $1^{a}$ edição. São Paulo. Malheiros Editores Ltda. 2004.

FERNANDEZ, Juán Antonio; Shengjun Liu. Guia do Empreendedor Estrangeiro na China: Casos de Sucesso. Traduzido por Sonia Augusto. Osasco-SP. Novo Século Editora. 2010.

FERRARA, Lucrécia D’Alessio. Do mundo como imagem à imagem do Mundo. In: Território. Globalização e Fragmentação. Organizadores Milton Santos, Maria Adélia A. De Souza e Maria Laura Silveira. São Paulo. Editora Hucitec. Anpur. 1996.

FIGUEIREDO, Natália de Lima. Poder da Marca. Interações entre direito antitruste e direito industrial. Dissertação de Mestrado apresentado no programa de pós-graduação em Direito da Faculdade de Direito da Universidade de São Paulo. 2014. Disponível em: https://www.teses.usp.br/teses/disponiveis/2/2132/tde-11042016-

134151/publico/Natalia_Figueiredo_dissertacao_mestrado.pdf. Último acesso em 20/12/2020.

FORRESTER, Viviane. Uma estranha ditadura. Tradução Vladimir Safatle. São Paulo. Editora Unesp, 2001.

FOUCAULT, Michel. Segurança, Território, População. Curso dado no Collège de France (1977-1978). Tradução Eduardo Brandão. São Paulo. Martins Fontes. 2008.

GALBRAITH, John Kenneth. Uma viagem pelo tempo econômico. Um relato em primeira mão. Tradução de Nivaldo Montingelli Jr. São Paulo. Editora Pioneira, 1994. 
GEROMEL, Ricardo. O Poder da China: o que você deve saber sobre o país que mais cresce em bilionários e unicórnios. São Paulo. Editora Gente. 2019.

GONG, Yeming. Global Operations Strategy: Fundamentals and Practice. New York. Springer. 2013.

HAN, Byung-Chul. Sociedade do Cansaço. Tradução de Enio Paulo Giachini. Petrópolis. Editora Vozes. 2017.

Editora Vozes. Petrópolis. 2018.

, No enxame - Perspectivas do Digital. Tradução de Lucas Machado.

HARARI, Yuval Noah. 21 lições para o século 21. São Paulo. Companhia das Letras, 2018.

HARDT, Michael; NEGRI, Antonio. Assembly. A organização multitudinária do comum. Tradução Lucas Carpinelli e Jefferson Viel. Editora Filosófica Politéia. São Paulo. 2018.

HARVEY, David. O Novo Imperialismo. 6a edição. Edições Loyola. São Paulo. 2012. Original de 2003.

HARVEY, David. The Enigma of Capital: and the crisis of Capitalism. Oxford. Oxford University Press. 2010.

HEATH, Christopher. In: RODRIGUES JR, Edson Beas; POLIDO Fabrício (organizadores). Propriedade intelectual: novos paradigmas, conflitos e desafios. Rio de Janeiro: Elsevier, 2007.

HUA, Yu. Viver. Tradução de Márcia Schmaltz. São Paulo. Companhia das Letras, 2008.

HUBERMAN, Leo. História da Riqueza dos E.U.A. (Nós, o Povo). São Paulo. Editora Brasiliense S/A. 1987.

HUNTINGTON, Samuel P. O Choque de civilizações e a recomposição da ordem mundial. Tradução de M.H.C. Cortes. Rio de Janeiro. Objetiva. 2010.

HUSSERL, Edmund. Da Lógica dos Sinais (Semiótica). Tradução de António Fidalgo. Disponível em http://bocc.ubi.pt/pag/fidalgo-husserl-semiotik.html. Acesso em 17/01/2018.

ISRAEL, Carolina Batista. Redes digitais, espaço de poder: sobre conflitos na reconfiguração da Internet e as estratégias de apropriação civil. Tese de doutorado defendida no programa de pós-graduação no Departamento de Geografia da Faculdade de Filosofia, Letras e Ciências Humanas da Universidade de São Paulo. 2019.

JABBOUR, Elias Marco Khalil. Projeto Nacional, Desenvolvimento e Socialismo de Mercado na China de Hoje. Tese de doutorado apresentado ao Departamento de Geografia da Universidade de São Paulo. 2010. 
Elias Marco Khalil. China - Socialismo e Desenvolvimento. Sete Décadas

Depois. São Paulo. Anita Garibaldi. Fundação Maurício Grabois. 2020.

JEUDY, Henri Pierre. Espelho das Cidades. Rio de Janeiro. Editora Casa das Palavras. 2005.

JOUANNET, Emmanuelle. The Liberal-Welfarist Law of Nations: A History of International Law. Cambridge. Cambridge University Press, 2012.

KAPOOR, Radhika; Tewari, Ritika. Investimentos Estrangeiros Diretos nas Economias BRIC: Mudando o cenário de investimento. In: Revista Tempo do Mundo. RTM. Volume 2. Número 2. Agosto de 2010.

KENNEDY, Paul. Ascensão e queda das grandes potências: transformação econômica e conflito militar de 1500 a 2000. Tradução de Wantensir Dutra. Rio de Janeiro. Editora Campus. 1989.

KEYNES, John Maynard. Teoria Geral do Emprego, do Juro e do Dinheiro. Editora Fundo de Cultura. Rio de Janeiro e Lisboa. 1970.

KISSINGER, Henry. Sobre a China. Tradução de Cássio de Arantes Leite. Rio de Janeiro. Editora Objetiva. 2011. Versão eletrônica disponível em: https://mundushistoriamoderna.files.wordpress.com/2018/04/5-sobre-a-china-henrykissinger.pdf.

KLEIN, Naomi. Sem Logo. A Tirania das marcas em um planeta vendido. Tradução de Ryta Vinagre. $2^{a}$ edição. Rio de Janeiro, São Paulo. Editora Record. 2002.

KRUGMAN, Paul. Increase return and economic geography. Journal of Political Economy. 1991. Vol 99, n. 3. The University of Chicago.

LANDES, David S. Riqueza e a Pobreza das Nações. Por que algumas são tão ricas e outras tão pobres. $6^{a}$ edição. Tradução Álvaro Cabral. Rio de Janeiro. Editora Campus, 1998.

LEFEBVRE, Henri. A vida cotidiana no mundo moderno. Lisboa. Editora Ulisséia. 1969.

LEMOINE, Françoise. Investimento Direto Estrangeiro. In: China Contemporânea. Tradução de Walter Sagadoy. Direção de Thierry Sanjuan.São Paulo. Edições 70. 2009.

LEMOS, Ronaldo. Inovação e competição na China. Folha de São Paulo. Caderno Mercado. P. A22. 27/05/2020.

LIEGSALZ, Johannes; WAGNER, Stefan. Patent examination at the State Intellectual Property Office in China. Research Policy 42. P. 552-563. 2013. Disponível em: 
https://www.sciencedirect.com/journal/research-policy/vol/42/issue/2. Acesso em 30/12/2020.

LIVESEY, Finbarr. From Global do Local. The making of things and the end of globalization. New York. Pantheon Books. 2017.

MALMBERG, Claes. Trademarks Statistics as innovation indicator: A micro study. In: Circle workingpaper. Lund University. 2005/2017 Disponível em: http://wp.circle.lu.se/upload/CIRCLE/workingpapers/200517_Malmberg.pdf. Acesso em 20/05/20.

MAMIGONIAN, Armen. Tecnologia e Desenvolvimento Desigual no Centro do Sistema Capitalista. Revista de Ciências Humanas. Florianópolis. Editora da UFSC, vol. 1, nº 2 , 1982.

MARINHO, Amanda Gonçalves. A invenção como parte do processo de industrialização: patentes inglesas no Brasil (1882-1910). Trabalho apresentado no XII Congresso Brasileiro de História Econômica e $13^{\mathrm{a}}$ Conferência Internacional de História de Empresas. Niterói. 2017. Disponível em: http://www.abphe.org.br/uploads/ABPHE\%202017/7\%20A\%20inven\%C3\%A7\%C3\% A3o\%20como\%20parte\%20do\%20processo\%20de\%20industrializa\%C3\%A7\%C3\%A 3o\%20patentes\%20inglesas\%20no\%20Brasil\%20(1882-1910).pdf. Acesso em 03/01/2020.

MARX, Karl. Manuscritos econômicos filosóficos. Tradução Jesus Ranieri. São Paulo. Editora Boitempo Editorial. 2004.

, Karl. O Capital. Crítica da Economia Política. Livro I. Tradução Rubens Enderle. Editora Boitempo Editorial. 2013.

MASSEY, Doreen. Um sentido global do lugar. In: O Espaço da Diferença. Organizador Antonio A. Arantes. Campinas. Editora Papirus. 2000.

MAZZUCATO, Mariana. O Estado Empreendedor. Desmascarando o mito do setor público vs. setor privado. Tradução Elvira Serapicos. $1^{a}$ edição. São Paulo. Portfolio Penguin. 2014.

MENELL, Peter S. Intellectual Property: General Theories. Levine's Working Paper Archive. 2003. Encyclopedia of Law \& Economics - 1600 Intellectual Property General Theories I FindLaw. Acesso em 21/12/2020.

MILLIGAN, Roberto Guerra. Trade Secrets: Intellectual Piracy and the origins of American Industrial Power, Doron S. Bem-Atar, New Haven, Yale University Press, 2004. 281 pp. In: Problemas del Desarrollo. Revista Latino Americana de Economia. 
Instituto de Investigaciones Económicas. Vol. 36, numero 140. Universidad Nacional Autónoma de México. México/DF. Janeiro-Março de 2005.

MORAES, Antonio Carlos Robert. Notas metodológicas sobre metropolização e a metrópole paulistana. In: Geografia das metrópoles. Ana Fani Alessandri Carlos e Ariovaldo Umbelino de Oliveira organizadores. São Paulo. Editora Contexto. 2006.

MURPHY, Craig N. Organização internacional e mudança industrial: governança global desde 1850. Tradução Fabio Storino. São Paulo. Editora Unesp. 2014.

NETTO, Antonio Delfim. Indústria 4.0. In Jornal Folha de São Paulo. 31 de janeiro de 2018. Pagina A2.

NIXON, Richard. The Real War. Sidgwick and Jackson. Londres. 1980.

O’BRIEN, Richard. Global Financial Integration: The end of Geography. New York. Council of Foreign Relations Press, 1992.

Richard; Keith, Alasdair. The Geography of Finance: after the storm. Cambridge Journal of Regions, Economy and Society. 2009. Disponível em http://www.outsights.co.uk/library/25/EndofGeographyrevisited. Acesso em 18/03/2014.

OCTAVIANI, Alessandro. Estudos, Pareceres e Votos de Direito Econômico. Editora Singular. São Paulo. 2014.

PIKETTY, Thomas. O Capital no Século XXI. Tradução Monica Baumgarten de Bolle. Rio de Janeiro. Editora Intrinseca. 2014

PIMENTEL, Luiz Otávio. Direito Industrial: as funções do direito de patentes. Porto Alegre. RS. Editora Síntese. 1999.

PIRICHINSKY, Damian. In: Vontade de apertar, Nathalia Durval. Folha Top of Mind 2019.

POMAR, Wladimir. O Enigma Chinês. Capitalismo ou Socialismo. São Paulo. Editora Alfa-Omega. 1987.

POLANYI, Karl. The Great Transformation. The Political and Economic Origins of Our Time. 2a. Edição da Beacon. Boston. Beacon Press, 2001.

Karl. A subsistência do homem e ensaios correlatos. Tradução Vera Ribeiro. Rio de Janeiro. Editora Contraponto. 2012.

POSNER, Richard A. e LANDES, William M. The Economic Structure of Intellectual Property Law. Cambridge Massachusetts and London England: The Belknap Press of Harvard University Press, 2003. 
POSNER. Richard A. Intellectual Property: The Law and Economics Approach. In Journal of Economic Perspectives - Volume 19, Number 2 - Spring 2005 - pages 5773.

em: http://people.ischool.berkeley.edu/ hal/Courses/StratTech09/Lectures/IP/Papers/posner 05.pdf. Acesso em 05/03/2014.

RANGEL, Ignácio. A história da dualidade brasileira. Revista de Economia Política, Vol.1, no 4, outubro-dezembro/1981.

REISS, Seth M. Commentary on The Paris Convention for the Protection of Industrial Property. 2008/2010. Disponível em: http://www.lex-ip.com/Paris.pdf. Acesso em $16 / 02 / 2014$.

ROAUNET, Sérgio Paulo. Ética e Antropologia. In: Revista Estudos Avançados do Instituto de Estudos Avançados da Universidade de São Paulo. Setembro/Dezembro de 1990. Volume 4, número 10.

RODRIK, Dani. Has Globalization Gone Too Far? Institute for International Economics. Washington, DC. 1997.

ROLNIK, Raquel. A Cidade e a Lei: legislação, política urbana e territórios na cidade de São Paulo. 2a edição. São Paulo. Studio Nobel. Fapesp. 1999.

ROSENTHAL, Jean-Laurent; WONG, R. Bin. Before and Beyond Divergence. The Politics of Economic Change in China and Europe. Cambridge, Massachusetts. London, England. 2011.

RUSSEL, Bertrand. O Elogio ao Ócio. Tradução de Pedro Jorgensen Júnior. Rio de Janeiro. Editora Sextante. 2002.

SAlOMÃO FILHO, Calixto. Teoria crítico-estruturalista do Direito Comercial. $1^{\mathrm{a}}$ edição. São Paulo. Marcial Pons Editora do Brasil Ltda. 2015.

SANTOS, José Nicolau dos. Revista da Faculdade de Direito da Universidade Federal do Paraná. Volume 4, n. 01956.

SANTOS, Milton. Relações Espaço-temporais no mundo subdesenvolvido. In: Seleção de Textos 1 - Dezembro de 1976. Disponível em: http://www.miltonsantos.com.br/site/wp-content/uploads/2011/12/Relacoesespa\%C3\%A7o-temporais-no-mundosubdesenvolvido_MiltonSantos1976SITE.pdf. Acesso em 14/03/2014.

Milton. A revolução tecnológica e o Território: Realidades e perspectivas. In: Terra Livre. n 9. São Paulo: AGB, julho - dezembro de 1991. P. 7-17.

, Milton. Metamorfoses do Espaço Habitado. Fundamentos teórico e metodológico da Geografia. São Paulo. $3^{\text {a }}$ edição. Hucitec. 1994. 
Milton. A Natureza do Espaço. Técnica e Tempo. Razão e Emoção. São

Paulo. Editora Hucitec. 1996.

, Milton. Técnica, Espaço, Tempo. Globalização e meio técnico-científico

informacional. $3^{a}$ edição. São Paulo. Editora Hucitec. 1997.

, Milton. Modo de produção técnico-científico e diferenciação espacial. Revista Território. Ano IV, nº 6, jan/jun 1999.

Milton. Por uma outra globalização. Do pensamento único à consciência universal. 6a edição. Rio de Janeiro. São Paulo. Editora Record, 2001.

Milton. Por uma Geografia Nova. Da Crítica da Geografia a uma Geografia Crítica. 6a edição. São Paulo. Editora da Universidade de São Paulo, 2004.

Milton. O espaço dividido. Os dois circuitos da economia urbana dos países subdesenvolvidos. Tradução Myrna T. Rego Viana. $2^{a}$ edição. São Paulo. Editora da Universidade de São Paulo. 2008.

Milton. Espaço e Método. $5^{\text {a }}$ edição. São Paulo. Editora da Universidade de São Paulo. 2012.

SANTOS, Milton; DE SOUZA, Maria Adélia A; SILVEIRA, Maria Laura. Território. Globalização e Fragmentação. São Paulo. Editora Hucitec. 1996.

SASSEN, Saskia. Expulsões: brutalidade e complexidade na economia global. Tradução Angélica Freitas. 1 ${ }^{a}$ edição. Rio de Janeiro/São Paulo. Editora Paz e Terra. 2016.

SCHMMIDT, Eric; ROSENBERG, Jonathan. Como o Google funciona. Tradução André Gordirro. Rio de Janeiro. Editora Intrínseca. 2015.

SCHNEUWLY, Anne Mirjam. International Investment Law and its Instruments: Managing Risks to Investors and Host States (August 1, 2012). Disponível em: https://papers.ssrn.com/sol3/papers.cfm?abstract_id=2200347. Acesso em 12/06/18.

SCHUMPETER, Joseph A. História da Análise Econômica. Volume 3. Tradução de Alfredo Moutinho do Reis, José Luis Silveira Miranda e Renato Rocha. $1^{\text {a }}$ edição. Rio de Janeiro, São Paulo e Lisboa. Editora Fundo de Cultura S/A, 1964.

SCUDELER, Marcelo Augusto. A propriedade industrial e a necessidade de proteção da criação humana. Disponível em: http://www.publicadireito.com.br/conpedi/manaus/arquivos/anais/recife/politica_marcel o_scudeler.pdf. Acesso em 06/05/18.

SHENG, Shu. A história da China Popular no século XX. $1^{\text {a }}$ edição. Rio de Janeiro. Editora FGV. 2012. 
SOUZA, Jonas Dias de. A relação entre a Geografia e o Direito: notas bibliográficas. Revista do Departamento de Geografia - USP, Volume 25 (2013), p. 285-307.

SMITH, Adam. A Riqueza das Nações. Investigação sobre sua Natureza e suas causas. Tradução de Luiz João Baraúna. Volume I. São Paulo. Editora Nova Cultural Ltda. 1996.

STEFANELI, Eduardo José. Engenharia Reversa. Discussão sobre validade e legalidade desta prática. Disponível em: http://www.stefanelli.eng.br/webpage/aengenharia-reversa.html. Acesso em 15/03/2014.

STIGLITZ, Joseph Eugene. É hora de questionar as patentes. Disponível em: http://outraspalavras.net/posts/stiglitz-e-hora-de-questionar-as-patentes/. Acesso em 05/02/2014.

TIROLE, Jean. Economia do Bem Comum. Tradução André Telles. São Paulo. Editora Zahar. 2020.

TSETUNG, Mao. Problemas estratégicos da Guerra Revolucionária na China. Obras Escolhidas. Pequim. Edições do Povo, 1952. Edições em Lingua Estrangeiras, 1975.

TOZI, Fabio. Rigidez normativa e flexibilidade tropical. Investigando os objetos técnicos no período da globalização. Tese apresentada ao Departamento de Geografia da Faculdade de Filosofia, Letras e Ciências Humanas da Universidade de São Paulo para a obtenção do título de Doutor em Geografia. São Paulo, 2012.

TROYJO, Marcos. O redesenho do mundo. Em crise, globalização já não é mais aquela. Folha de São Paulo, 31/07/16. Caderno Ilustríssima pg. 4. Disponível em: http://www1.folha.uol.com.br/ilustrissima/2016/07/1796521-mundo-passa-por-umredesenho-desglobalizatorio-defende-diplomata.shtml. Acesso em 02/08/16.

TUAN, Yi-Fu. Topofilia: um estudo da percepção, atitudes e valores do meio ambiente. Tradução Livia de Oliveira. Editora da Universidade Estadual de Londrina. Londrina. 2012.

WALLERSTEIN, Immanuel. Capitalismo Histórico e Civilização Capitalista. Tradução Renato Aguiar. Rio de Janeiro: Contraponto, 2001.

WEBER, Max. História Geral da Economia. Tradução Calógeras A. Pajuaba. São Paulo. Editora Mestre Jou. 1968.

WOLF, Tom. Ficar ou não ficar. Tradução de Paulo Reis. Rio de Janeiro. Editora Rocco. 2001.

WU, Tim. Impérios da Comunicação: do telefone à internet, da ATT\&T ao google. Tradução Cláudio Carina. Rio de Janeiro. Editora Zahar, 2012. 


\section{ARTIGOS DE JORNAIS E REVISTAS}

CARAZZAI, Estelita Hass. Trump quer barreiras contra a China na área de propriedade intelectual. Folha de São Paulo, São Paulo, 17 mar 2018. Caderno Mercado, p. A24.

DURVAL, Nathalia. Vontade de apertar. Folha Top of Mind 2019. Folha de São Paulo.

RODRIK, Dani. Entrevista de Dani Rodrik. Disponível em: https://saudeempublico.blogfolha.uol.com.br/2020/08/23/globalizacao-almejada-ate-achegada-do-virus-e-inatingivel/. Acesso em 03/09/2020.

RODRIK, Dani. Disponível em: https://www.ft.com/content/c2beedfe-964d-11e8-95f88640db9060a7. Acesso em 01/01/2021.

SKALAIR, Leslie. The Transnacional Capitalist Class and the Discourse of Globalization. In: Cambridge Review of International Affairs. 2000 Disponível em: https://www.globalpolicy.org/globalization/defining-globalization/27656-the-

transnational-capitalist-class-and-the-discourse-of-globalization.html. Acesso em $18 / 06 / 2018$.

SWANSON, Ana; KANG,Cecilia; RAPPERPORT, Alan. Trump's Killing of Chip Deal Pushes Protectionism as It Invokes Secutiry. New York Times, 13 mar 2018. Disponível em: $\quad$ HTTP://www.nytimes.com/2007/04/2010/business/world/business/10trade.html. Acesso em 22/03/2018.

VALENTE, Jonas. Agência Brasil. 2019. Disponível em: https://agenciabrasil.ebc.com.br/geral/noticia/2019-09/mais-de-5-bilhoes-de-pessoasusam-aparelho-celular-revela-pesquisa. Acesso em 29/03/2020.

WEI, Shang-Jin; XIE, Zhuan; Zhang Xiaobo. From "Made in China" to "Innovated in China": Necessity, Prospect, and Challenges. The Journal of Economic Perspectives, Winter 2017, Vol. 31, No 1 (Winter 2017), p. 49-70. American Economic Association. Disponível em http://www.jstor.com/stable/44133950. Acesso em 10/12/2020.

WEISMAN, Steven R. U.S. Toughens Its Position on China Trade. New York Times, 10 abr 2007. Disponível em: HTTP://www.nytimes.com/2007/04/10/business/worldbusiness/10trade.html. Acesso em $22 / 03 / 18$. 


\section{REVISTAS}

Exame. Editora Abril. Disponível em: http://exame.abril.com.br/negocios/ab-inbevvende-5-marcas-de-cerveja-para-asahi-por-e-73-bilhoes/. Acesso em 04/04/17.

O Globo. Disponível em: http://oglobo.globo.com/economia/unilever-prepara-venda-demarcas-de-alimentos-por-us-744-bilhoes-21083727. Acesso em 04/04/17

\section{SITES E BLOGS CONSULTADOS}

Banco Mundial. Disponível em: https://www.worldbank.org/. Acesso em 14/10/2020.

Banco Mundial. Relatório "Comércio para o Desenvolvimento. Na Era da Cadeia Global de Valor", 2020. No original: Trading for Development. In The Age of Global Value Chain. "Disponível em: file:///C:/Users/eanda/Downloads/9781464814570.pdf. Acesso em $14 / 10 / 2020$.

Clarin. Disponível em https://www.clarin.com/clarin-em-portugues/destaque/chinamaior-investidor-unidos_0_S1uhrODPl.html. Acesso em 03/07/2018.

CNBS. Disponível em: https://www.cnbc.com/2019/01/24/smartphones-72percent-ofpeople-will-use-only-mobile-for-internet-by-

2025.html\#: :text=WARC\%20estimates\%20that $\% 20$ around $\% 202$, base $\% 20$ of $\% 203.9 \%$ 20mobile\%20users. Acesso em 06/10/20.

Daxue Consulting. Disponível em: http://daxueconsulting.com/bottled-water-marketin-chinal. Acesso em: 23/02/2018.

Diário do Comércio e Indústria - DCI. Disponível em: https://www.dci.com.br/opiniao/direto-da-china/mercado-interno-chines-sustentamarcas-domesticas-de-bens-de-consumo-1.663231/3.291475. Acesso em 23/02/2018.

Environmental Protection Agency - EPA. Disponível em: https://www.epa.gov/dwreginfo/information-about-public-water-systems. Acesso em 03/06/18.

European Comission. Disponível em: https://ec.europa.eu/commission/presscorner/detail/en/IP_20_2541. Último acesso em 01/01/2021.

Foodbev. Disponível em: https://www.foodbev.com/news/the-chinese-bottled-watermarket/. Acesso em 13/02/2017. 
Governo da Província de Hangzhou. Disponível em: http://eng.hangzhou.gov.cn/col/col1450889/index.html. Acesso em 15/12/2020.

IAM - Intelectual Property Business Media Platform. https://www.iammedia.com/copyright/why-india-worried-about-royalty-payments-foreign-companies. Último acesso em 23/12/2020.

Interbrand. Disponível em http://interbrand.com/. Acesso em 28/06/18.

Money. Disponível em: https://money.cnn.com/interactive/economy/chineseacquisitions-us-companies/. Acesso em 03/07/2018.

Mundo das Marcas. Disponível em: http://mundodasmarcas.blogspot.com.br/2006/05/coca-cola-always.html. Acesso em $\underline{12 / 06 / 2018 .}$.

Organização Mundial do Comércio. Disponível em: https://www.wto.org/. Último acesso em: 28/12/2020.

Organização Mundial da Propriedade Intelectual. Disponível em: https://www.wipo.int/portal/en/index.html. Último acesso em: 28/12/2020.

Paris Innovation Review. Disponível em: http://parisinnovationreview.com/articlesen/chinas-standardization-strategies. Acesso em 18/06/18.

Statistas. Disponível em: https://www.statistas.com.. Último acesso em 03/07/18

Targethd. Disponível em: https://targethd.net/fim-da-guerra-de-patentes-e-samsungtem-que-pagar-mais-us-539-milhoes-para-a-apple/. Acesso em 18/06/18

World Atlas. Disponível em: https://www.worldatlas.com. Último acesso em 03/07/18

\section{DOCUMENTOS}

Memorando de Bill Gates à equipe executiva da Microsoft que consta dos autos do processo Unites States v. Microsoft 253 F.3d 34 (D.C.Cir. 2001). Disponível em: https://www.justice.gov/sites/default/files/atr/legacy/2006/03/03/20.pdf. Acesso em 02/07/2020.

The Elements of the China Challenge". Equipe de planejamento de políticas. Escritório do Secretario de Estado. Disponível em: https://www.state.gov/wpcontent/uploads/2020/11/20-02832-Elements-of-China-Challenge508.pdf?fbclid=IwAR2Fxv4ScMMSnMevUmi_VEJE3p9y_wazVAHC_Yp7iFXEkbV Nuq2U104SLM. Acesso em 17/11/2020. 


\begin{abstract}
ANEXOS
Anexo I

ACORDO SOBRE ASPECTOS DOS DIREITOS DE PROPRIEDADE INTELECTUAL RELACIONADOS AO COMÉRCIO (ACORDO TRIPS OU ACORDO ADPIC) (1994)

PARTE I - DISPOSIÇÕES GERAIS E PRINCÍPIOS BÁSICOS

PARTE II - PADRÕES RELATIVOS À EXISTÊNCIA, ABRANGÊNCIA E EXERCÍCIO DE DIREITOS DE PROPRIEDADE INTELECTUAL 1. Direito do Autor e Direitos Conexos; 2. Marcas; 3. Indicações Geográficas; 4. Desenhos Industriais; 5. Patentes; 6. Topografias de Circuitos Integrados; 7. Proteção de Informação Confidencial; e 8. Controle de Práticas de Concorrência Desleal em Contratos de Licenças. 7

PARTE III - APLICAÇÃO DE NORMAS DE PROTEÇÃO DOS DIREITOS DE PROPRIEDADE INTELECTUAL 1. Obrigações Gerais; 2. Procedimentos e Remédios Civis e Administrativos; 3. Medidas Cautelares; 4. Exigência Especiais Relativas a Medidas de Fronteira; e 5. Procedimentos Penais.

PARTE IV - OBTENÇÃO E MANUTENÇÃO DE DIREITOS DE PROPRIEDADE INTELECTUAL E PROCEDIMENTOS INTER-PARTES CONEXOS

PARTE V - PREVENÇÃO E SOLUÇÃO DE CONTROVÉRSIAS

PARTE VI ARRANJOS TRANSITÓRIOS

PARTE VII - ARRANJOS INSTITUCIONAIS;

DISPOSIÇÕES FINAIS
\end{abstract}

Os Membros, desejando reduzir distorções e obstáculos ao comércio internacional e levando em consideração a necessidade de promover uma proteção eficaz e adequada dos direitos de propriedade intelectual e assegurar que as medidas e procedimentos destinados a fazê-los respeitar não se tornem, por sua vez, obstáculos ao comércio legítimo; Reconhecendo, para tanto, a necessidade de novas regras e disciplinas relativas: (a) à aplicabilidade dos princípios básicos do GATT 1994 e dos acordos e convenções internacionais relevantes em matéria de propriedade intelectual; (b) ao estabelecimento de padrões e princípios adequados relativos à existência, abrangência e exercício de direitos de propriedade intelectual relacionados ao comércio; (c) ao estabelecimento de meios eficazes e apropriados para a aplicação de normas de proteção de direitos de propriedade intelectual relacionados ao comércio, levando em consideração as diferenças existentes entre os sistemas jurídicos nacionais; (d) ao estabelecimento de procedimentos eficazes e expeditos para a prevenção e solução multilaterais de controvérsias entre Governos; e (e) às disposições transitórias voltadas à plena participação nos resultados das negociações; Reconhecendo a necessidade de um arcabouço de princípios, regras e disciplinas multilaterais sobre o comércio internacional de bens contrafeitos; Reconhecendo que os direitos de propriedade intelectual são direitos privados; Reconhecendo os objetivos básicos de política pública dos sistemas nacionais para a proteção da propriedade intelectual, inclusive os objetivos de desenvolvimento e tecnologia; Reconhecendo igualmente as necessidades especiais dos países de menor desenvolvimento relativo Membros no que se refere à implementação interna de leis e regulamentos com a máxima flexibilidade, de forma a habilitá-los a criar uma base tecnológica sólida e viável; Ressaltando a importância de reduzir tensões mediante a 
obtenção de compromissos firmes para a solução de controvérsias sobre questões de propriedade intelectual relacionadas ao comércio, por meio de procedimentos multilaterais; Desejando estabelecer relações de cooperação mútua entre a OMC e a Organização Mundial da Propriedade Intelectual (denominada neste Acordo como OMPI), bem como com outras organizações internacionais relevantes; Acordam, pelo presente, o que se segue:

\section{PARTE I - DISPOSIÇÕES GERAIS E PRINCÍPIOS BÁSICOS}

Artigo 1 - Natureza e Abrangência das Obrigações

1. Os Membros colocarão em vigor o disposto neste Acordo. Os Membros poderão, mas não estarão obrigados a prover, em sua legislação, proteção mais ampla que a exigida neste Acordo, desde que tal proteção não contrarie as disposições deste Acordo. Os Membros determinarão livremente a forma apropriada de implementar as disposições deste Acordo no âmbito de seus respectivos sistema e prática jurídicos.

2. Para os fins deste Acordo, o termo "propriedade intelectual" refere-se a todas as categorias de propriedade intelectual que são objeto das Seções 1 a 7 da Parte II.

3. Os Membros concederão aos nacionais de outros Membros (1) o tratamento previsto neste Acordo. No que concerne ao direito de propriedade intelectual pertinente, serão considerados nacionais de outros Membros as pessoas físicas ou jurídicas que atendam aos critérios para usufruir da proteção prevista estabelecidos na Convenção de Paris (1967), na Convenção de Berna (1971), na Convenção de Roma e no Tratado sobre Propriedade Intelectual em Matéria de Circuitos Integrados, quando todos Membros do Acordo Constitutivo da OMC forem Membros dessas Convenções (2). Todo Membro que faça uso das possibilidades estipuladas no parágrafo 3 do Artigo 5 ou no parágrafo 2 do Artigo 6 da Convenção de Roma fará uma notificação, segundo previsto naquelas disposições, ao Conselho para os Aspectos dos Direitos de Propriedade Intelectual Relacionados ao Comércio (o "Conselho para TRIPS").

$1 \mathrm{O}$ termo "nacionais" é utilizado neste Acordo para designar, no caso de um território aduaneiro separado Membro da OMC, pessoas físicas ou jurídicas, que tenham domicílio ou um estabelecimento industrial ou comercial real e efetivo naquele território aduaneiro 2 Neste Acordo, o termo "Convenção de Paris" refere-se à Convenção de Paris para a Proteção da Propriedade Industrial; "Convenção de Paris (1967)" refere-se a Ata de Estocolmo dessa Convenção de 14 de julho de 1967. O termo "Convenção de Berna" refere-se à Convenção de Berna relativa à Proteção das Obras Literárias e Artísticas; "Convenção de Berna (1971)" refere-se à Ata de Paris dessa Convenção de 24 de julho de 1971. O termo "Convenção de Roma" refere-se à Convenção Internacional para a Proteção dos Artistas-Intérpretes, Produtores de Fonogramas e Organizações de Radiodifusão, adotada em Roma em 26 de outubro de 1961. O termo "Tratado sobre a Propriedade Intelectual em Matéria de Circuitos Integrados" (Tratado PICI) refere-se ao Tratado sobre a Propriedade

Artigo 2 - Convenções sobre Propriedade Intelectual. 1 Com relação às Partes II, III e IV deste Acordo, os Membros cumprirão o disposto nos Artigos 1 a 12, e 19, da Convenção de Paris (1967). 2 Nada nas Partes I a IV deste Acordo derrogará as obrigações existentes que os Membros possam ter entre si, em virtude da Convenção de Paris, da Convenção de Berna, da Convenção de Roma e do Tratado sobre a Propriedade Intelectual em Matéria de Circuitos Integrados.

Artigo 3 - Tratamento Nacional 1. Cada Membro concederá aos nacionais dos demais Membros tratamento não menos favorável que o outorgado a seus próprios nacionais com relação à proteção3 da propriedade intelectual, salvo as exceções já previstas, respectivamente, na Convenção de Paris (1967), na Convenção de Berna (1971), na 
Convenção de Roma e no Tratado sobre Propriedade Intelectual em Matéria de Circuitos Integrados. No que concerne a artistas-intérpretes, produtores de fonogramas e organizações de radiodifusão, essa obrigação se aplica apenas aos direitos previstos neste Acordo. Todo Membro que faça uso das possibilidades previstas no Artigo 6 da Convenção de Berna e no parágrafo 1 (b) do Artigo 16 da Convenção de Roma fará uma notificação, de acordo com aquelas disposições, ao Conselho para TRIPS. 2. Os Membros poderão fazer uso das exceções permitidas no parágrafo 1 em relação a procedimentos judiciais e administrativos, inclusive a designação de um endereço de serviço ou a nomeação de um agente em sua área de jurisdição, somente quando tais exceções sejam necessárias Intelectual em Matéria de Circuitos Integrados, adotado em Washington em 26 de maio de 1989. O termo "Acordo Constitutivo da OMC" refere-se ao Acordo que cria a OMC. 3 Para os efeitos dos Artigos 3 e 4 deste Acordo, a "proteção" compreenderá aspectos que afetem a existência, obtenção, abrangência, manutenção e aplicação de normas de proteção dos direitos de propriedade intelectual, bem como os aspectos relativos ao exercício dos direitos de propriedade intelectual de que trata especificamente este Acordo para assegurar o cumprimento de leis e regulamentos que não sejam incompatíveis com as disposições deste Acordo e quando tais práticas não sejam aplicadas de maneira que poderiam constituir restrição disfarçada ao comércio.

Artigo 4 - Tratamento de Nação Mais Favorecida. Com relação à proteção da propriedade intelectual, toda vantagem, favorecimento, privilégio ou imunidade que um Membro conceda aos nacionais de qualquer outro país será outorgada imediata e incondicionalmente aos nacionais de todos os demais Membros. Está isenta desta obrigação toda vantagem, favorecimento, privilégio ou imunidade concedida por um Membro que: (a) resulte de acordos internacionais sobre assistência judicial ou sobre aplicação em geral da lei e não limitados em particular à proteção da propriedade intelectual; (b) tenha sido outorgada em conformidade com as disposições da Convenção de Berna (1971) ou da Convenção de Roma que autorizam a concessão tratamento em função do tratamento concedido em outro país e não do tratamento nacional; (c) seja relativa aos direitos de artistasintérpretes, produtores de fonogramas e organizações de radiodifusão não previstos neste Acordo; (d) resultem de Acordos internacionais relativos à proteção da propriedade intelectual que tenham entrado em vigor antes da entrada em vigor do Acordo Constitutivo da OMC, desde que esses acordos sejam notificados ao Conselho para TRIPS e não constituam discriminação arbitrária ou injustificável contra os nacionais dos demais Membros.

Artigo 5 - Acordos Multilaterais sobre Obtenção ou Manutenção da Proteção As obrigações contidas nos Artigos 3 e 4 não se aplicam aos procedimentos previstos em acordos multilaterais concluídos sob os auspícios da OMPI relativos à obtenção e manutenção dos direitos de propriedade intelectual.

Artigo 6 - Exaustão. Para os propósitos de solução de controvérsias no marco deste Acordo, e sem prejuízo do disposto nos Artigos 3 e 4, nada neste Acordo será utilizado para tratar da questão da exaustão dos direitos de propriedade intelectual.

Artigo 7 - Objetivos. A proteção e a aplicação de normas de proteção dos direitos de propriedade intelectual devem contribuir para a promoção da inovação tecnológica e para a transferência e difusão de tecnologia, em benefício mútuo de produtores e usuários de conhecimento tecnológico e de uma forma conducente ao bem-estar social econômico e a um equilíbrio entre direitos e obrigações.

Artigo 8 - Princípios. 1 Os Membros, ao formular ou emendar suas leis e regulamentos, podem adotar medidas necessárias para proteger a saúde e nutrição públicas e para promover o interesse público em setores de importância vital para seu desenvolvimento sócioeconômico e tecnológico, desde que estas medidas sejam compatíveis com o 
disposto neste Acordo. 2. Desde que compatíveis com o disposto neste Acordo, poderão ser necessárias medidas apropriadas para evitar o abuso dos direitos de propriedade intelectual por seus titulares ou para evitar o recurso a práticas que limitem de maneira injustificável o comércio ou que afetem adversamente a transferência internacional de tecnologia.

\section{PARTE II NORMAS RELATIVAS À EXISTÊNCIA, ABRANGÊNCIA E EXERCÍCIO DOS DIREITOS DE PROPRIEDADE INTELECTUAL SEÇÃO 1: DIREITO DO AUTOR E DIREITOS CONEXOS}

Artigo 9 - Relação com a Convenção de Berna. 1. Os Membros cumprirão o disposto nos Artigos 1 a 21 e no Apêndice da Convenção de Berna (1971). Não obstante, os Membros não terão direitos nem obrigações, neste Acordo, com relação aos direitos conferidos pelo Artigo 6bis da citada Convenção, ou com relação aos direitos dela derivados. 2. A proteção do direito do autor abrangerá expressões e não idéias, procedimentos, métodos de operação ou conceitos matemáticos como tais.

Artigo 10 - Programas de Computador e Compilações de Dados 1. Programas de computador, em código fonte ou objeto, serão protegidos como obras literárias pela Convenção de Berna (1971). 2. As compilações de dados ou de outro material, legíveis por máquina ou em outra forma, que em função da seleção ou da disposição de seu conteúdo constituam criações intelectuais, deverão ser protegidas como tal. Essa proteção, que não se estenderá aos dados ou ao material em si, se dará sem prejuízo de qualquer direito autoral subsistente nesses dados ou material.

Artigo 11 - Direitos de Aluguel. Um Membro conferirá aos autores e a seus sucessores legais, pelo menos no que diz respeito a programas de computador e obras cinematográficas, o direito de autorizar ou proibir o aluguel público comercial dos originais ou das cópias de suas obras protegidas pelo direito do autor. Um Membro estará isento desta obrigação no que respeita a obras cinematográficas, a menos que esse aluguel tenha dado lugar a uma ampla copiagem dessas obras, que comprometa significativamente o direito exclusivo de reprodução conferido por um Membro aos autores e seus sucessores legais. Com relação aos programas de computador, esta obrigação não se aplica quando o programa em si não constitui o objeto essencial do aluguel.

Artigo 12 - Duração da Proteção. Quando a duração da proteção de uma obra, que não fotográfica ou de arte aplicada, for calculada em base diferente à da vida de uma pessoa física, esta duração não será inferior a 50 anos, contados a partir do fim do ano civil da publicação autorizada da obra ou, na ausência dessa publicação autorizada nos 50 anos subseqüentes à realização da obra, a 50 anos, contados a partir do fim do ano civil de sua realização.

Artigo 13 - Limitações e Exceções. Os Membros restringirão as limitações ou exceções aos direitos exclusivos a determinados casos especiais, que não conflitem com a exploração normal da obra e não prejudiquem injustificavelmente os interesses legítimos do titular do direito.

Artigo 14 - Proteção de Artistas-Intérpretes, Produtores de Fonogramas (Gravações Sonoras) e Organizações de Radiodifusão 1. No que respeita à fixação de suas apresentações em fonogramas, os artistas-intérpretes terão a possibilidade de evitar a fixação de sua apresentação não fixada e a reprodução desta fixação, quando efetuadas sem sua autorização. Os artistas intérpretes terão também a possibilidade de impedir a difusão por meio de transmissão sem fio e a comunicação ao público de suas apresentações ao vivo, quando efetuadas sem sua autorização. 2. Os produtores de fonogramas gozarão do direito de autorizar ou proibir a reprodução direta ou indireta de 
seus fonogramas. 3. As organizações de radiodifusão terão o direito de proibir a fixação, a reprodução de fixações e a retransmissão por meios de difusão sem fio, bem como a comunicação ao público de suas transmissões televisivas, quando efetuadas sem sua autorização. Quando não garantam esses direitos às organizações de radiodifusão, os Membros concederão aos titulares do direito de autor, nas matérias objeto das transmissões, a possibilidade de impedir os atos antes mencionados, sujeitos às disposições da Convenção de Berna (1971). 4. As disposições do Artigo 11 relativas a programas de computador serão aplicadas mutatis mutandis aos produtores de fonogramas e a todos os demais titulares de direitos sobre fonogramas, segundo o determinado pela legislação do Membro. Se, em 15 de abril de 1994, um Membro tiver em vigor um sistema eqüitativo de remuneração dos titulares de direitos no que respeita ao aluguel de fonogramas, poderá manter esse sistema desde que o aluguel comercial de fonogramas não esteja causando prejuízo material aos direitos exclusivos de reprodução dos titulares de direitos. 5. A duração da proteção concedida por este Acordo aos artistasintérpretes e produtores de fonogramas se estenderá pelo menos até o final de um prazo de 50 anos, contados a partir do final do ano civil no qual a fixação tenha sido feita ou a apresentação tenha sido realizada. A duração da proteção concedida de acordo com o parágrafo 3 será de pelo menos 20 anos, contados a partir do fim do ano civil em que a transmissão tenha ocorrido. 6. Todo Membro poderá, em relação aos direitos conferidos pelos parágrafos 1, 2 e 3, estabelecer condições, limitações, exceções e reservas na medida permitida pela Convenção de Roma. Não obstante, as disposições do Artigo 18 da Convenção de Berna (1971) também serão aplicadas, mutatis mutandis, aos direitos sobre os fonogramas de artistas-intérpretes e produtores de fonogramas.

SEÇÃO 2: MARCAS

Artigo 15 - Objeto da Proteção. 1. Qualquer sinal, ou combinação de sinais, capaz de distinguir bens e serviços de um empreendimento daqueles de outro empreendimento, poderá constituir uma marca. Estes sinais, em particular palavras, inclusive nomes próprios, letras, numerais, elementos figurativos e combinação de cores, bem como qualquer combinação desses sinais, serão registráveis como marcas. Quando os sinais não forem intrinsecamente capazes de distinguir os bens e serviços pertinentes, os Membros poderão condicionar a possibilidade do registro ao caráter distintivo que tenham adquirido pelo seu uso. Os Membros poderão exigir, como condição para o registro, que os sinais sejam visualmente perceptíveis. 2. O disposto no parágrafo 1 não será entendido como impedimento a que um Membro denegue o registro de uma marca por outros motivos, desde que estes não infrinjam as disposições da Convenção de Paris (1967). 3. Os Membros poderão condicionar a possibilidade do registro ao uso da marca. Não obstante, o uso efetivo de uma marca não constituirá condição para a apresentação de pedido de registro. Uma solicitação de registro não será indeferida apenas com base no fato de que seu uso pretendido não tenha ocorrido antes de expirado um prazo de três anos, contados a partir da data da solicitação. 4. A natureza dos bens ou serviços para os quais se aplique uma marca não constituíra, em nenhum caso, obstáculo a seu registro. 5. Os Membros publicarão cada marca antes ou prontamente após o seu registro e concederão oportunidade razoável para o recebimento de pedidos de cancelamento do registro. Ademais, os Membros poderão oferecer oportunidade para que o registro de uma marca seja contestado.

Artigo 16 Direitos Conferidos 1. O titular de marca registrada gozará do direito exclusivo de impedir que terceiros, sem seu consentimento, utilizem em operações comerciais sinais idênticos ou similares para bens ou serviços que sejam idênticos ou similares àqueles para os quais a marca está registrada, quando esse uso possa resultar em confusão. No caso de utilização de um sinal idêntico para bens e serviços idênticos presumir-se-á uma 
possibilidade de confusão. Os direitos descritos acima não prejudicarão quaisquer direitos prévios existentes, nem afetarão a possibilidade dos Membros reconhecerem direitos baseados no uso. 2. O disposto no Artigo 6bis da Convenção de Paris (1967) aplicar-seá, mutatis mutandis, a serviços. Ao determinar se uma marca é notoriamente conhecida, os Membros levarão em consideração o conhecimento da marca no setor pertinente do público, inclusive o conhecimento que tenha sido obtido naquele Membro, como resultado de promoção da marca. 3. O disposto no Artigo 6bis da Convenção de Paris (1967) aplicar-se-á, mutatis mutandis, aos bens e serviços que não sejam similares àqueles para os quais uma marca esteja registrada, desde que o uso dessa marca, em relação àqueles bens e serviços, possa indicar uma conexão entre aqueles bens e serviços e o titular da marca registrada e desde que seja provável que esse uso prejudique os interesses do titular da marca registrada.

Artigo 17 - Exceções. Os Membros poderão estabelecer exceções limitadas aos direitos conferidos para uma marca, tal como o uso adequado de termos descritivos, desde que tais exceções levem em conta os legítimos interesses do titular da marca e de terceiros.

Artigo 18 - Duração da Proteção. O registro inicial de uma marca, e cada uma das renovações do registro, terá duração não inferior a sete anos. O registro de uma marca será renovável indefinidamente.

Artigo 19 - Requisito do Uso. 1. Se sua manutenção requer o uso da marca, um registro só poderá ser cancelado após transcorrido um prazo ininterrupto de pelo menos três anos de não-uso, a menos que o titular da marca demonstre motivos válidos, baseados na existência de obstáculos a esse uso. Serão reconhecidos como motivos válidos para o nãouso circunstâncias alheias à vontade do titular da marca, que constituam um obstáculo ao uso da mesma, tais como restrições à importação ou outros requisitos oficiais relativos aos bens e serviços protegidos pela marca. 2. O uso de uma marca por outra pessoa, quando sujeito ao controle de seu titular, será reconhecido como uso da marca para fins de manutenção do registro.

Artigo 20 - Outros Requisitos. O uso comercial de uma marca não será injustificavelmente sobrecarregado com exigências especiais, tais como o uso com outra marca, o uso em uma forma especial ou o uso em detrimento de sua capacidade de distinguir os bens e serviços de uma empresa daqueles de outra empresa. Esta disposição não impedirá uma exigência de que uma marca que identifique a empresa produtora de bens e serviços seja usada juntamente, mas não vinculadamente, com a marca que distinga os bens e serviços específicos em questão daquela empresa.

Artigo 21 - Licenciamento e Cessão. Os Membros poderão determinar as condições para a concessão de licenças de uso e cessão de marcas, no entendimento de que não serão permitidas licenças compulsórias e que o titular de uma marca registrada terá o direito de ceder a marca, com ou sem a transferência do negócio ao qual a marca pertença. SEÇÃO 3: INDICAÇÕES GEOGRÁFICAS

Artigo 22 - Proteção das Indicações Geográficas. 1. Indicações geográficas são, para os efeitos deste Acordo, indicações que identifiquem um produto como originário do território de um Membro, ou região ou localidade deste território, quando determinada qualidade, reputação ou outra característica do produto seja essencialmente atribuída à sua origem geográfica. 2. Com relação às indicações geográficas, os Membros estabelecerão os meios legais para que as partes interessadas possam impedir: (a) a utilização de qualquer meio que, na designação ou apresentação do produto, indique ou sugira que o produto em questão provém de uma área geográfica distinta do verdadeiro lugar de origem, de uma maneira que conduza o público a erro quanto à origem geográfica do produto; (b) qualquer uso que constitua um ato de concorrência desleal, no sentido do disposto no Artigo 10bis da Convenção de Paris (1967). 3. Um Membro recusará ou 
invalidará, ex officio, se sua legislação assim o permitir, ou a pedido de uma parte interessada, o registro de uma marca que contenha ou consista em indicação geográfica relativa a bens não originários do território indicado, se o uso da indicação na marca para esses bens for de natureza a induzir o público a erro quanto ao verdadeiro lugar de origem. 4. As disposições dos parágrafos 1, 2 e 3 serão aplicadas a uma indicação geográfica que, embora literalmente verdadeira no que se refere ao território, região ou localidade da qual o produto se origina, dê ao público a falsa idéia de que esses bens se originam em outro território.

Artigo 23. Proteção Adicional às Indicações Geográficas para Vinhos e Destilados. 1. Cada Membro proverá os meios legais para que as partes interessadas possam evitar a utilização de uma indicação geográfica que identifique vinhos em vinhos não originários do lugar indicado pela indicação geográfica em questão, ou que identifique destilados como destilados não originários do lugar indicado pela indicação geográfica em questão, mesmo quando a verdadeira origem dos bens esteja indicada ou a indicação geográfica utilizada em tradução ou acompanhada por expressões como "espécie", "tipo", "estilo", "imitação" ou outras similares4. 2. O registro de uma marca para vinhos que contenha ou consista em uma indicação geográfica que identifique vinhos, ou para destilados que contenha ou consista em uma indicação geográfica que identifique destilados, será recusado ou invalidado, ex officio, se a legislação de um Membro assim o permitir, ou a pedido de uma parte interessada, para os vinhos ou destilados que não tenham essa origem. 3. No caso de indicações geográficas homônimas para vinhos, a proteção será concedida para cada indicação, sem prejuízo das disposições do parágrafo 4 do Artigo 22. Cada Membro determinará as condições práticas pelas quais serão diferenciadas entre si as indicações geográficas homônimas em questão, levando em consideração a necessidade de assegurar tratamento eqüitativo aos produtores interessados e de não induzir a erro os consumidores. 4. Para facilitar a proteção das indicações geográficas para vinhos, realizar-se-ão, no Conselho para TRIPS, negociações relativas ao estabelecimento de um sistema multilateral de notificação e registro de indicações geográficas para vinhos passíveis de proteção nos Membros participantes desse sistema. 4. Sem prejuízo do disposto na primeira frase do Artigo 42, os Membros poderão alternativamente, com relação a essas obrigações, estabelecer medidas administrativas para lograr normas de proteção

Artigo 24 - Negociações Internacionais; Exceções. 1. Os Membros acordam entabular negociações com o objetivo de aumentar a proteção às indicações geográficas específicas mencionadas no Artigo 23. As disposições dos parágrafos 4 a 8 abaixo não serão utilizadas por um Membro como motivo para deixar de conduzir negociações ou de concluir acordos bilaterais e multilaterais. No contexto de tais negociações, os Membros se mostrarão dispostos a considerar a aplicabilidade ulterior dessas disposições a indicações geográficas especificas cuja utilização tenha sido o objeto dessas negociações. 2. O Conselho para TRIPS manterá sob revisão a aplicação das disposições desta Seção; a primeira dessas revisões será realizada dentro de dois anos da entrada em vigor do Acordo Constitutivo da OMC. Qualquer questão que afete o cumprimento das obrigações estabelecidas nessas disposições poderá ser levada à atenção do Conselho, o qual, a pedido de um Membro, realizará consultas com qualquer outro Membro ou Membros sobre as questões para as quais não tenha sido possível encontrar uma solução satisfatória mediante consultas bilaterais ou multilaterais entre os Membros interessados. O Conselho adotará as medidas que se acordem para facilitar o funcionamento e para a consecução dos objetivos dessa Seção. 3. Ao implementar as disposições dessa Seção, nenhum Membro reduzirá a proteção às indicações geográficas que concedia no período imediatamente anterior à data de entrada em vigor do Acordo Constitutivo da OMC. 4. 
Nada nesta Seção exigirá que um Membro evite o uso continuado e similar de uma determinada indicação geográfica de outro Membro, que identifique vinhos e destilados em relação a bens e serviços, por nenhum de seus nacionais ou domiciliários que tenham utilizado esta indicação geográfica de forma continuada para esses mesmos bens e serviços, ou outros afins, no território desse Membro (a) por, no mínimo, 10 anos antes de 15 de abril de 1994 ou, (b) de boa fé, antes dessa data. 5. As medidas adotadas para implementar esta Seção não prejudicarão a habilitação ao registro, a validade do registro, nem o direito ao uso de uma marca, com base no fato de que essa marca é idêntica ou similar a uma indicação geográfica, quando essa marca tiver sido solicitada ou registrada de boa fé, ou quando os direitos a essa marca tenham sido adquiridos de boa fé mediante uso: (a) antes da data de aplicação dessas disposições naquele Membro, segundo estabelecido na Parte VI; ou (b) antes que a indicação geográfica estivesse protegida no seu país de origem; 6. Nada nesta Seção obrigará um Membro a aplicar suas disposições a uma indicação geográfica de qualquer outro Membro relativa a bens e serviços para os quais a indicação pertinente seja idêntica ao termo habitual em linguagem corrente utilizado como nome comum para os mesmos bens e serviços no território daquele Membro. Nada do previsto nesta Seção obrigará um Membro a aplicar suas disposições a uma indicação geográfica de qualquer outro Membro relativa a produtos de viticultura para os quais a indicação relevante seja igual ao nome habitual para uma variedade de uva existente no território daquele Membro na data da entrada em vigor do Acordo Constitutivo da OMC. 7. Um Membro poderá estabelecer que qualquer requerimento formulado no âmbito desta Seção, relativo ao uso ou registro de uma marca, deve ser apresentado dentro de um prazo de cinco anos após tornado do conhecimento geral naquele Membro o uso sem direito da indicação protegida, ou após a data do registro da marca naquele Membro, desde que a marca tenha sido publicada até aquela data, quando anterior à data na qual o uso sem direito tornou-se do conhecimento geral naquele Membro, desde que a indicação geográfica não seja utilizada ou registrada de má fé. 8. As disposições desta Seção não prejudicarão de forma alguma o direito de qualquer pessoa de usar, em operações comerciais, seu nome ou o de seu predecessor no negócio, exceto quando esse nome for utilizado de maneira que induza o público a erro 9 . Não haverá, neste Acordo, obrigação de proteger indicações geográficas que não estejam protegidas, que tenham deixado de estar protegidas ou que tenham caído em desuso no seu país de origem.

\section{SEÇÃO 4: DESENHOS INDUSTRIAIS}

Artigo 25 - Requisitos para a Proteção. 1. Os Membros estabelecerão proteção para desenhos industriais criados independentemente, que sejam novos ou originais. Os Membros poderão estabelecer que os desenhos não serão novos ou originais se estes não diferirem significativamente de desenhos conhecidos ou combinações de características de desenhos conhecidos. Os Membros poderão estabelecer que essa proteção não se estenderá a desenhos determinados essencialmente por considerações técnicas ou funcionais. 2. Cada Membro assegurará que os requisitos para garantir proteção a padrões de tecidos - particularmente no que se refere a qualquer custo, exame ou publicação não dificulte injustificavelmente a possibilidade de buscar e de obter essa proteção. Os Membros terão liberdade para cumprir com essa obrigação por meio de lei sobre desenhos industriais ou mediante lei de direito autoral.

Artigo 26 - Proteção 1. O titular de um desenho industrial protegido terá o direito de impedir terceiros, sem sua autorização, de fazer, vender ou importar artigos que ostentem ou incorporem um desenho que constitua um cópia, ou seja substancialmente uma cópia, do desenho protegido, quando esses atos sejam realizados com fins comerciais. 2. Os 
Membros poderão estabelecer algumas exceções à proteção de desenhos industriais, desde que tais exceções não conflitem injustificavelmente com a exploração normal de desenhos industriais protegidos, nem prejudiquem injustificavelmente o legítimo interesse do titular do desenho protegido, levando em conta o legítimo interesse de terceiros. 3. A duração da proteção outorgada será de, pelo menos, dez anos.

\section{SEÇÃO 5: PATENTES}

Artigo 27 - Matéria Patenteável 1. Sem prejuízo do disposto nos parágrafos 2 e 3 abaixo, qualquer invenção, de produto ou de processo, em todos os setores tecnológicos, será patenteável, desde que seja nova, envolva um passo inventivo e seja passível de aplicação industrial5. Sem prejuízo do disposto no parágrafo 4 do Artigo 65, no parágrafo 8 do Artigo 70 e no parágrafo 3 deste Artigo, as patentes serão disponíveis e os direitos patentários serão usufruíveis sem discriminação quanto ao local de invenção, quanto a seu setor tecnológico e quanto ao fato de os bens serem importados ou produzidos localmente. 2. Os Membros podem considerar como não patenteáveis invenções cuja exploração em seu território seja necessário evitar para proteger a ordem pública ou a moralidade, inclusive para proteger a vida ou a saúde humana, animal ou vegetal ou para evitar sérios prejuízos ao meio ambiente, desde que esta determinação não seja feita apenas por que a exploração é proibida por sua legislação. 3. Os Membros também podem considerar como não patenteáveis: (a) métodos diagnósticos, terapêuticos e cirúrgicos para o tratamento de seres humanos ou de animais; (b) plantas e animais, exceto microorganismos e processos essencialmente biológicos para a produção de plantas ou animais, excetuando-se os processos não-biológicos e microbiológicos. Não obstante, os Membros concederão proteção a variedades vegetais, seja por meio de patentes, seja por meio de um sistema sui generis eficaz, seja por uma combinação de ambos. $\mathrm{O}$ disposto neste subparágrafo será revisto quatro anos após a entrada em vigor do Acordo Constitutivo da OMC.

5. Para os fins deste Artigo, os termos "passo inventivo" e "passível de aplicação industrial" podem ser caracterizados por um Membro como sinônimos aos termos "não óbvio" e "utilizável".

Artigo 28 - Direitos Conferidos 1. Uma patente conferirá a seu titular os seguintes direitos exclusivos: (a) quando o objeto da patente for um produto, o de evitar que terceiros sem seu consentimento produzam, usem, coloquem a venda, vendam, ou importem6 com esses propósitos aqueles bens; (b) quando o objeto da patente for um processo, o de evitar que terceiros sem seu consentimento usem o processo e usem, coloquem a venda, vendam, ou importem com esses propósitos pelo menos o produto obtido diretamente por aquele processo. 2. Os titulares de patente terão também o direito de cedê-la ou transferila por sucessão e o de efetuar contratos de licença.

6. Esse direito, como todos os demais direitos conferidos por esse Acordo relativos ao uso, venda, importação ou outra distribuição de bens, está sujeito ao disposto no Artigo 6.

$7 \mathrm{O}$ termo "outro uso" refere-se ao uso diferente daquele permitido pelo Artigo 30.

Artigo 29 - Condições para os Requerentes de Patente 1. Os Membros exigirão que um requerente de uma patente divulgue a invenção de modo suficientemente claro e completo para permitir que um técnico habilitado possa realizá-la e podem exigir que o requerente indique o melhor método de realizar a invenção que seja de seu conhecimento no dia do pedido ou, quando for requerida prioridade, na data prioritária do pedido. 2. Os Membros podem exigir que o requerente de uma patente forneça informações relativas a seus pedidos correspondentes de patente e às concessões no exterior. 
Artigo 30 - Exceções aos Direitos Conferidos. Os Membros poderão conceder exceções limitadas aos direitos exclusivos conferidos pela patente, desde que elas não conflitem de forma não razoável com sua exploração normal e não prejudiquem de forma não razoável os interesses legítimos de seu titular, levando em conta os interesses legítimos de terceiros.

Artigo 31 - Outro Uso sem Autorização do Titular. Quando a legislação de um Membro permite outro uso7 do objeto da patente sem a autorização de seu titular, inclusive o uso pelo Governo ou por terceiros autorizados pelo governo, as seguintes disposições serão respeitadas (a) a autorização desse uso será considerada com base no seu mérito individual; (b) esse uso só poderá ser permitido se o usuário proposto tiver previamente buscado obter autorização do titular, em termos e condições comerciais razoáveis, e que esses esforços não tenham sido bem sucedidos num prazo razoável. Essa condição pode ser dispensada por um Membro em caso de emergência nacional ou outras circunstâncias de extrema urgência ou em casos de uso público não comercial. No caso de uso público não comercial, quando o Governo ou o contratante sabe ou tem base demonstrável para saber, sem proceder a uma busca, que uma patente vigente é ou será usada pelo ou para o Governo, o titular será prontamente informado; (c) o alcance e a duração desse uso será restrito ao objetivo para o qual foi autorizado e, no caso de tecnologia de semicondutores, será apenas para uso público não-comercial ou para remediar um procedimento determinado como sendo anticompetitivo ou desleal após um processo administrativo ou judicial; (d) esse uso será não-exclusivo; (e) esse uso não será transferível, exceto conjuntamente com a empresa ou parte da empresa que dele usufruir; (f) esse uso será autorizado predominantemente para suprir o mercado interno do Membro que autorizou; (g) sem prejuízo da proteção adequada dos legítimos interesses das pessoas autorizadas, a autorização desse uso poderá ser terminada se e quando as circunstâncias que o propiciaram deixarem de existir e se for improvável que venham a existir novamente. A autoridade competente terá o poder de rever, mediante pedido fundamentado, se essas circunstâncias persistem; (h) o titular será adequadamente remunerado nas circunstâncias de cada uso, levando-se em conta o valor econômico da autorização; (i) a validade legal de qualquer decisão relativa à autorização desse uso estará sujeita a recurso judicial ou outro recurso independente junto a uma autoridade claramente superior naquele Membro; (j) qualquer decisão sobre a remuneração concedida com relação a esse uso estará sujeita a recurso judicial ou outro recurso independente junto a uma autoridade claramente superior naquele Membro; (k) os Membros não estão obrigados a aplicar as condições estabelecidas nos subparágrafos (b) e (f) quando esse uso for permitido para remediar um procedimento determinado como sendo anti-competitivo ou desleal após um processo administrativo ou judicial. A necessidade de corrigir práticas anti-competitivas ou desleais pode ser levada em conta na determinação da remuneração em tais casos. As autoridades competentes terão o poder de recusar a terminação da autorização se e quando as condições que a propiciam forem tendentes a ocorrer novamente; (1) quando esse uso é autorizado para permitir a exploração de uma patente ("a segunda patente") que não pode ser explorada sem violar outra patente ("a primeira patente"), as seguintes condições adicionais serão aplicadas: (i) a invenção identificada na segunda patente envolverá um avanço técnico importante de considerável significado econômico em relação à invenção identificada na primeira patente; (ii) o titular da primeira patente estará habilitado a receber uma licença cruzada, em termos razoáveis, para usar a invenção identificada na segunda patente; e (iii) o uso autorizado com relação à primeira patente será não transferível, exceto com a transferência da segunda patente.

Artigo 32 - Nulidade/Caducidade Haverá oportunidade para recurso judicial contra qualquer decisão de anular ou de caducar uma patente. 
Artigo 33 - Vigência. A vigência da patente não será inferior a um prazo de 20 anos, contados a partir da data do depósito8. 8 Entende-se que aqueles Membros que não dispõem de um sistema de concessão original podem dispor que o termo de proteção será contado a partir da data de depósito no sistema de concessão original.

Artigo 34 - Patentes de Processo: Ônus da Prova. 1. Para os fins de processos cíveis relativos à infração dos direitos do titular referidos no parágrafo 1(b) do Artigo 28, se o objeto da patente é um processo para a obtenção de produto, as autoridades judiciais terão o poder de determinar que o réu prove que o processo para obter um produto idêntico é diferente do processo patenteado. Conseqüentemente, os Membros disporão que qualquer produto idêntico, quando produzido sem o consentimento do titular, será considerado, na ausência de prova em contrário, como tendo sido obtido a partir do processo patenteado, pelo menos em uma das circunstâncias seguintes: (a) se o produto obtido pelo processo patenteado for novo; (b) se existir probabilidade significativa de o produto idêntico ter sido feito pelo processo e o titular da patente não tiver sido capaz, depois de empregar razoáveis esforços, de determinar o processo efetivamente utilizado. 2. Qualquer Membro poderá estipular que o ônus da prova indicado no parágrafo 1 recairá sobre a pessoa a quem se imputa a infração apenas quando satisfeita a condição referida no subparágrafo (a) ou apenas quando satisfeita a condição referida no subparágrafo (b). 3. Na adução da prova em contrário, os legítimos interesses dos réus na proteção de seus segredos de negócio e de fábrica serão levados em consideração.

\section{SEÇÃO 6: TOPOGRAFIAS DE CIRCUITOS INTEGRADOS}

Artigo 35 - Relação com o Tratado sobre a Propriedade Intelectual em Matéria de Circuitos Integrados. Os Membros acordam outorgar proteção às topografias de circuitos integrados (denominados adiante "topografias") em conformidade com os Artigos 2 a 7 (salvo o parágrafo 3 do Artigo 6), Artigo 12 e parágrafo 3 do Artigo 16 do Tratado sobre Propriedade Intelectual em Matéria de Circuitos Integrados e, adicionalmente, em cumprir com as disposições seguintes.

Artigo 36 - Abrangência da Proteção Sem prejuízo do disposto no parágrafo 1 do Artigo 37, os Membros considerarão ilícitos os seguintes atos, se realizados sem autorização do titular do direito9: importar, vender ou distribuir por outro modo para fins comerciais uma topografia protegida, um circuito integrado no qual esteja incorporada uma topografia protegida ou um artigo que incorpore um circuito integrado desse tipo, somente na medida em que este continue a conter uma reprodução ilícita de uma topografia.

9. Entende-se que o termo "titular de direito" possui, nesta Seção, o mesmo significado do termo "titular do direito" no Tratado sobre a Propriedade Intelectual em Matéria de Circuitos Integrados

Artigo 37 - Atos que não Exigem a Autorização do Titular do Direito 1. Sem prejuízo do Disposto no Artigo 36, nenhum Membro considerará ilícita a realização de qualquer dos atos a que se refere aquele Artigo em relação a um circuito integrado que contenha uma topografia reproduzida de forma ilícita ou a qualquer produto que incorpore um tal circuito integrado, quando a pessoa que tenha efetuado ou ordenado tais atos não sabia e não tinha base razoável para saber, quando da obtenção do circuito integrado ou do produto, que ele continha uma topografia reproduzida de forma ilícita. Os Membros disporão que, após essa pessoa ter sido suficientemente informada de que a topografia fora reproduzida de forma ilícita, ela poderá efetuar qualquer daqueles atos com relação ao estoque disponível ou previamente encomendado, desde que pague ao titular do direito uma quantia equivalente a uma remuneração razoável, equivalente à que seria paga no caso de uma licença livremente negociada daquela topografia. 2. As condições estabelecidas nos subparágrafos (a) a (k) do Artigo 31 aplicar-se-ão, mutatis mutandis, 
no caso de qualquer licenciamento não-voluntário de uma topografia ou de seu uso pelo ou para o Governo sem a autorização do titular do direito.

Artigo 38 - Duração da Proteção 1. Nos Membros que exigem o registro como condição de proteção, a duração da proteção de topografias não expirará antes de um prazo de dez anos contados do depósito do pedido de registro ou. da primeira exploração comercial, onde quer que ocorra no mundo. 2. Nos Membros que não exigem registro como condição de proteção, as topografias serão protegidas por um prazo não inferior a dez anos da data da primeira exploração comercial, onde quer que ocorra no mundo. 3. Sem prejuízo dos parágrafos 1 e 2, um Membro pode dispor que a proteção terminará quinze anos após a criação da topografia.

\section{SEÇÃO 7: PROTEÇÃO DE INFORMAÇÃO CONFIDENCIAL}

Artigo 39 - 1. Ao assegurar proteção efetiva contra competição desleal, como disposto no Artigo 10bis da Convenção de Paris (1967), os Membros protegerão informação confidencial de acordo com o parágrafo 2 abaixo, e informação submetida a Governos ou a Agências Governamentais, de acordo com o parágrafo 3 abaixo. 2. Pessoas físicas e jurídicas terão a possibilidade de evitar que informação legalmente sob seu controle seja divulgada, adquirida ou usada por terceiros, sem seu consentimento, de maneira contrária a práticas comerciais honestas10, desde que tal informação: (a) seja secreta, no sentido de que não seja conhecida em geral nem facilmente acessível a pessoas de círculos que normalmente lidam com o tipo de informação em questão, seja como um todo, seja na configuração e montagem específicas de seus componentes; (b) tenha valor comercial por ser secreta; e (c) tenha sido objeto de precauções razoáveis, nas circunstâncias, pela pessoa legalmente em controle da informação, para mantê-la secreta. 3. Os Membros que exijam a apresentação de resultados de testes ou outros dados não divulgados, cuja elaboração envolva esforço considerável, como condição para aprovar a comercialização de produtos farmacêuticos ou de produtos agrícolas químicos que utilizem novas entidades químicas, protegerão esses dados contra seu uso comercial desleal. Ademais, os Membros adotarão providências para impedir que esses dados sejam divulgados, exceto quando necessário para proteger o público, ou quando tenham sido adotadas medidas para assegurar que os dados sejam protegidos contra o uso comercial desleal.

10. Para os fins da presente disposição, a expressão "de maneira contrária a práticas comerciais honestas" significará pelo menos práticas como violação ao contrato, abuso de confiança, indução à infração, e inclui a obtenção de informação confidencial por terceiros que tinham conhecimento, ou desconheciam por grave negligência, que a obtenção dessa informação envolvia tais práticas.

\section{SEÇÃO 8: CONTROLE DE PRÁTICAS DE CONCORRÊNCIA DESLEAL EM CONTRATOS DE LICENÇAS}

Artigo 40 - 1. Os Membros concordam que algumas práticas ou condições de licenciamento relativas a direitos de propriedade intelectual que restringem a concorrência podem afetar adversamente o comércio e impedir a transferência e disseminação de tecnologia. 2. Nenhuma disposição deste Acordo impedirá que os Membros especifiquem em suas legislações condições ou práticas de licenciamento que possam, em determinados casos, constituir um abuso dos direitos de propriedade intelectual que tenha efeitos adversos sobre a concorrência no mercado relevante. Conforme estabelecido acima, um Membro pode adotar, de forma compatível com as outras disposições deste Acordo, medidas apropriadas para evitar ou controlar tais práticas, que podem incluir, por exemplo, condições de cessão exclusiva, condições que impeçam impugnações da validade e pacotes de licenças coercitivos, à luz das leis e 
regulamentos pertinentes desse Membro. 3. Cada Membro aceitará participar de consultas quando solicitado por qualquer outro Membro que tenha motivo para acreditar que um titular de direitos de propriedade intelectual, que seja nacional ou domiciliado no Membro ao qual o pedido de consultas tenha sido dirigido, esteja adotando práticas relativas à matéria da presente Seção, em violação às leis e regulamentos do Membro que solicitou as consultas e que deseja assegurar o cumprimento dessa legislação, sem prejuízo de qualquer ação legal e da plena liberdade de uma decisão final por um ou outro Membro. O Membro ao qual tenha sido dirigida a solicitação dispensará consideração plena e receptiva às consultas com o Membro solicitante, propiciará adequada oportunidade para sua realização e cooperará mediante o fornecimento de informações não confidenciais, publicamente disponíveis, que sejam de relevância para o assunto em questão, e de outras informações de que disponha o Membro, sujeito à sua legislação interna e à conclusão de acordos mutuamente satisfatórios relativos à salvaguarda do seu caráter confidencial pelo Membro solicitante. 4. Um Membro, cujos nacionais ou pessoas nele domiciliadas estejam sujeitas a ações judiciais em outro Membro, relativas a alegada violação de leis e regulamentos desse outro Membro em matéria objeto desta Seção, terá oportunidade, caso assim o solicite, para efetuar consultas na mesmas condições previstas no parágrafo 3.

\section{PARTE III APLICAÇÃO DE NORMAS DE PROTEÇÃO DOS DIREITOS DE PROPRIEDADE INTELECTUAL}

\section{SEÇÃO 1: OBRIGAÇÕES GERAIS}

Artigo 41 - 1. Os Membros assegurarão que suas legislações nacionais disponham de procedimentos para a aplicação de normas de proteção como especificadas nesta Parte, de forma a permitir uma ação eficaz contra qualquer infração dos direitos de propriedade intelectual previstos neste Acordo, inclusive remédios expeditos destinados a prevenir infrações e remédios que constituam um meio de dissuasão contra infrações ulteriores. Estes procedimentos serão aplicados de maneira a evitar a criação de obstáculos ao comércio legítimo e a prover salvaguardas contra seu uso abusivo. 2. Os procedimentos relativos a aplicação de normas de proteção dos direitos de propriedade intelectual serão justos e eqüitativos. Não serão desnecessariamente complicados ou onerosos, nem comportarão prazos não razoáveis ou atrasos indevidos. 3. As decisões sobre o mérito de um caso serão, de preferência, escritas e fundamentadas. Estarão à disposição, pelo menos das partes do processo, sem atraso indevido. As decisões sobre o mérito de um caso serão tomadas apenas com base em provas sobre as quais as partes tenham tido oportunidade de se manifestar. 4. As Partes de um processo terão a oportunidade de que uma autoridade judicial reveja as decisões administrativas finais e pelo menos os aspectos legais das decisões judiciais iniciais sobre o mérito do pedido, sem prejuízo das disposições jurisdicionais da legislação de um Membro relativa a importância do caso. Não haverá obrigação, contudo, de prover uma oportunidade para revisão de absolvições em casos criminais. 5. O disposto nesta Parte não cria qualquer obrigação de estabelecer um sistema jurídico para a aplicação de normas de proteção da propriedade intelectual distinto do já existente para aplicação da legislação em geral. Nenhuma das disposições desta Parte cria qualquer obrigação com relação à distribuição de recursos entre a aplicação de normas destinadas à proteção dos direitos de propriedade intelectual e a aplicação da legislação em geral.

\section{SEÇÃO 2: PROCEDIMENTOS E REMÉDIOS CIVIS E ADMINISTRATIVOS}


Artigo 42 - Procedimentos Justos e Eqüitativos. Os Membros farão com que os titulares de direito11 possam dispor de procedimentos judiciais civis relativos à aplicação de normas de proteção de qualquer direito de propriedade intelectual coberto por este Acordo. Os réus terão direito a receber, em tempo hábil, intimação por escrito que contenha detalhes suficientes, inclusive as razões das pretensões. Será permitido às partes fazer-se representar por um advogado independente e os procedimentos não imporão exigências excessivas quanto à obrigatoriedade de comparecimento pessoal. Todas as partes nesses procedimentos estarão devidamente habilitadas a fundamentar suas pretensões e a apresentar todas as provas pertinentes. $\mathrm{O}$ procedimento fornecerá meios para identificar e proteger informações confidenciais, a menos que isto seja contrário a disposições constitucionais vigentes.

11. Para efeitos desta Parte, o termo "titular de direito" inclui federações e associações que possuam capacidade legal para exercer tais direitos.

Artigo 43 - Provas 1. Quando uma parte tiver apresentado provas razoavelmente acessíveis, suficientes para sustentar suas pretensões e tiver indicado provas relevantes para a fundamentação de suas pretensões que estejam sob o controle da parte contrária, as autoridades judiciais terão o poder de determinar que esta apresente tais provas, sem prejuízo, quando pertinente, das condições que asseguram proteção da informação confidencial. 2. Nos casos em que uma das parte no processo denegue, voluntariamente ou sem motivos válidos, acesso a informação necessária, ou não a forneça dentro de prazo razoável, ou obstaculize significativamente um procedimento relativo a uma ação de aplicação de normas de proteção, um Membro pode conceder às autoridades judiciais 0 poder de realizar determinações judiciais preliminares e finais, afirmativas ou negativas, com base nas informações que lhes tenham sido apresentadas, inclusive a reclamação ou a alegação apresentada pela parte adversamente afetada pela recusa de acesso à informação, sob condição de conceder às partes oportunidade de serem ouvidas sobre as alegações ou provas.

Artigo 44 - Ordens Judiciais 1. As autoridades judiciais terão o poder de determinar que uma parte cesse uma violação, inter alia para impedir a entrada nos canais de comércio sob sua jurisdição de bens importados que envolvam violação de um direito de propriedade intelectual, imediatamente após a liberação alfandegária de tais bens. Os Membros não estão obrigados a conceder este poder com relação a matéria protegida, que tenha sido adquirida ou encomendada por uma pessoa antes de saber, ou de ter motivos razoáveis para saber, que operar com essa matéria ensejaria a violação de um direito de propriedade intelectual. 2. Não obstante as demais disposições desta Parte e desde que respeitadas as disposições da Parte II, relativas especificamente à utilização por Governos, ou por terceiros autorizados por um Governo, sem a autorização do titular do direito, os Membros poderão limitar os remédios disponíveis contra tal uso ao pagamento de remuneração, conforme o disposto na alínea (h) do Artigo 31. Nos outros casos, os remédios previstos nesta Parte serão aplicados ou, quando esses remédios forem incompatíveis com a legislação de um Membro, será possível obter sentenças declaratórias e compensação adequada.

Artigo 45 - Indenizações 1. As autoridades judiciais terão o poder de determinar que o infrator pague ao titular do direito uma indenização adequada para compensar o dano que este tenha sofrido em virtude de uma violação de seu direito de propriedade intelectual cometido por um infrator que tenha efetuado a atividade infratora com ciência, ou com base razoável para ter ciência. 2. As autoridades judiciais terão também o poder de determinar que o infrator pague as despesas do titular do direito, que poderão incluir os honorários apropriados de advogado. Em casos apropriados, os Membros poderão autorizar as autoridades judiciais a determinar a reparação e/ou o pagamento de 
indenizações previamente estabelecidas, mesmo quando o infrator não tenha efetuado a atividade infratora com ciência, ou com base razoável para ter ciência.

Artigo 46 - Outros Remédios. A fim de estabelecer um elemento de dissuasão eficaz contra violações, as autoridades judiciais terão o poder de determinar que bens, que se tenha determinado sejam bens que violem direitos de propriedade intelectual, sejam objeto de disposição fora dos canais comerciais, sem qualquer forma de compensação, de tal maneira a evitar qualquer prejuízo ao titular do direito, ou, quando esse procedimento for contrário a requisitos constitucionais em vigor, que esses bens sejam destruídos. As autoridades judiciais terão também o poder de determinar que materiais e implementos cujo uso predominante tenha sido o de elaborar os bens que violam direitos de propriedade intelectual sejam objeto de disposição fora dos canais comerciais, sem qualquer forma de compensação, de maneira a minimizar os riscos de violações adicionais. Na consideração desses pedidos, será levada em conta a necessidade de proporcionalidade entre a gravidade da violação e os remédios determinados, bem como os interesses de terceiras partes. Com relação a bens com marca contrafeita, a simples remoção da marca ilicitamente afixada não será suficiente para permitir a liberação dos bens nos canais de comércio, a não ser em casos excepcionais.

Artigo 47 - Direito à Informação. Os Membros poderão dispor que as autoridades judiciais tenham o poder de determinar que o infrator informe ao titular do direito a identidade de terceiras pessoas envolvidas na produção e distribuição dos bens ou serviços que violem direitos de propriedade intelectual e de seus canais de distribuição, a menos que isto seja desproporcional à gravidade da violação.

Artigo 48 - Indenização do Réu. 1. As autoridades judiciais terão o poder de determinar que uma parte, a pedido da qual tenham sido tomadas medidas e que tenha abusado dos procedimentos de aplicação de normas de proteção de direitos de propriedade intelectual, provenha à parte que tenha sido equivocadamente objeto de ordem judicial ou de medida cautelar compensação adequada pelo prejuízo em que incorreu por conta desse abuso. As autoridades judiciais terão também o poder de determinar ao demandante que pague as despesas do réu, que podem incluir honorários adequados de advogado. 2. Os Membros só poderão isentar autoridades e funcionários públicos de estarem sujeitos a medidas apropriadas de reparação, relativas à aplicação de qualquer lei sobre a proteção ou a observância de direitos de propriedade intelectual, quando as ações tiverem sido efetuadas ou pretendidas de boa fé, no contexto da aplicação daquela legislação.

Artigo 49 - Procedimentos Administrativos. Na medida em que qualquer remédio cível possa ser determinado como decorrência de procedimentos administrativos sobre o mérito de um caso, esses procedimentos conformar-se-ão a princípios substantivamente equivalentes aos estabelecidos nesta Seção.

\section{SEÇÃO 3: MEDIDAS CAUTELARES.}

Artigo 50 - 1. As autoridades judiciais terão o poder de determinar medidas cautelares rápidas e eficazes: (a) para evitar a ocorrência de uma violação de qualquer direito de propriedade intelectual, em especial para evitar a entrada nos canais comerciais sobre sua jurisdição de bens, inclusive de bens importados, imediatamente após sua liberação alfandegária; (b) para preservar provas relevantes relativas a uma alegada violação. 2 . As autoridades judiciais terão o poder de adotar medidas cautelares, inaudita altera parte, quando apropriado, em especial quando qualquer demora tenderá a provocar dano irreparável ao titular do direito, ou quando exista um risco comprovado de que as provas sejam destruídas. 3. As autoridades judiciais terão o poder de exigir que o requerente forneça todas as provas razoavelmente disponíveis, de modo a se convencer, com grau suficiente de certeza, que o requerente é o titular do direito e que seu direito está sendo 
violado ou que tal violação é iminente e de determinar que o requerente deposite uma caução ou garantia equivalente, suficiente para proteger o réu e evitar abuso. 4. Quando medidas cautelares tenham sido adotadas inaudita altera parte, as partes afetadas serão notificadas sem demora, no mais tardar após a execução das medidas. Uma revisão, inclusive o direito a ser ouvido, terá lugar mediante pedido do réu, com vistas a decidir, dentro de um prazo razoável após a notificação das medidas, se essas medidas serão alteradas, revogadas ou mantidas. 5. A autoridade que executará as medidas cautelares poderá requerer ao demandante que ele provenha outras informações necessárias à identificação dos bens pertinentes. 6 . Sem prejuízo do disposto no parágrafo 4 , as medidas cautelares adotadas com base nos parágrafos 1 e 2 serão revogadas ou deixarão de surtir efeito, quando assim requisitado pelo réu, se o processo conducente a uma decisão sobre o mérito do pedido não for iniciado dentro de um prazo razoável. Nos casos em que a legislação de um Membro assim o permitir, esse prazo será fixado pela autoridade judicial que determinou as medidas cautelares. Na ausência de sua fixação, o prazo não será superior a 20 dias úteis ou a 31 dias corridos, o que for maior. 7. Quando as medidas cautelares forem revogadas, ou quando elas expirarem em função de qualquer ato ou omissão por parte do demandante, ou quando for subseqüentemente verificado que não houve violação ou ameaça de violação a um direito de propriedade intelectual, as autoridades judiciais, quando solicitadas pelo réu, terão o poder de determinar que o demandante forneça ao réu compensação adequada pelo dano causado por essas medidas. 8. Na medida em que qualquer medida cautelar possa ser determinada como decorrência de procedimentos administrativos, esses procedimentos conformar-se-ão a princípios substantivamente equivalentes aos estabelecidos nesta Seção.

\section{SEÇÃO 4: EXIGÊNCIAS ESPECIAIS RELATIVAS A MEDIDAS DE FRONTEIRA12}

Artigo 51 - Suspensão de Liberação pelas Autoridades Alfandegárias. Os Membros adotarão procedimentos 13, de acordo com as disposições abaixo, para permitir que 14 possa ocorrer, apresente um requerimento por escrito junto às autoridades competentes, administrativas ou judiciais, para a suspensão pelas autoridades alfandegárias da liberação desses bens. Os Membros podem permitir que um requerimento dessa natureza seja feito com relação a bens que envolvam outras violações de direitos de propriedade intelectual, desde que as exigências desta Seção sejam satisfeitas. Os Membros também podem permitir processos correspondentes, relativos à suspensão da liberação pelas autoridades alfandegárias de bens que violem direitos de propriedade intelectual destinados à exportação de seus territórios.

12 Quando um Membro tiver desmontado substantivamente todos os controles sobre a movimentação de bens através de sua fronteira com outro Membro com o qual ele faz parte de uma união aduaneira, ele não estará obrigado a aplicar as disposições desta Seção naquela fronteira.

13 Fica entendido que não haverá obrigação de aplicar esses procedimentos a importações de bens colocado no mercado de um terceiro país pelo titular do direito ou com o seu consentimento, nem a bens em trânsito. um titular de direito, que tenha base válida para suspeitar que a importação de bens com marca contrafeita ou pirateados.

14 Para os efeitos deste Acordo, entende-se por: (a) "bens com marca contrafeita" quaisquer bens, inclusive a embalagem, que ostentem sem autorização uma marca que seja idêntica à marca registrada relativa a tais bens, ou que não pode ser distinguida, em seus aspectos essenciais, dessa marca e que, por conseguinte, viola os direitos do titular da marca registrada em questão na legislação do país de importação; (b) "bens pirateados" quaisquer bens que constituam cópias efetuadas sem a permissão do titular do direito ou 
de pessoa por ele devidamente autorizada no país onde foi produzido e que são elaborados direta ou indiretamente a partir de um Artigo no qual a elaboração daquela cópia teria constituído uma violação de um direito autoral ou conexo na legislação do país de importação.

Artigo 52 - Requerimento. Qualquer titular de direito que inicie os procedimentos previstos no ARTIGO 51 terá de fornecer provas adequadas para satisfazer as autoridades competentes, de acordo com a legislação do país de importação, que existe, prima facie, uma violação do direito de propriedade intelectual do titular do direito e de fornecer uma descrição suficientemente detalhada dos bens, de forma a que sejam, facilmente reconhecidos pelas autoridades alfandegárias. As autoridades competentes informarão ao requerente, dentro de um prazo de tempo razoável, se aceitaram o requerimento e, quando determinado pelas autoridades competentes, o prazo em que agirão as autoridades alfandegárias.

Artigo 53 - Caução ou Garantia Equivalente. 1. As autoridades competentes terão o poder de exigir que o requerente deposite uma caução ou garantia equivalente, suficiente para proteger o requerido e evitar abuso. Essa caução ou garantia equivalente não deterá, despropositadamente, o recurso a esses procedimentos. 2. De acordo com o requerimento previsto nessa Seção, quando a liberação de bens envolvendo desenhos industriais, patentes, topografias de circuito integrado ou informações confidenciais tiver sido suspensa pelas autoridades alfandegárias, com base numa decisão que não tenha sido tomada por uma autoridade judicial ou por outra autoridade independente, e o prazo estipulado no Artigo 55 tenha expirado sem a concessão de alívio provisório pelas autoridades devidamente capacitadas, o proprietário, importador ou consignatário desses bens terá direito à sua liberação quando depositar uma caução suficiente para proteger o titular do direito de qualquer violação, desde que todas as outras condições de importação tenham sido cumpridas. O pagamento dessa caução não restringirá o direito a outros remédios disponíveis para o titular do direito, ficando entendido que a caução será liberada se o titular do direito desistir do direito de litigar dentro de um prazo razoável.

Artigo 54. Notificação de Suspensão. O importador e o requerente serão prontamente notificados da suspensão da liberação dos bens, de acordo com o Artigo 51.

Artigo 55. Duração da Suspensão. Se as autoridades alfandegárias não tiverem sido informadas, num prazo de até 10 dias úteis após a notificação ao requerente da suspensão da liberação, de que um processo tendente a uma decisão sobre o mérito do pedido tenha sido iniciado por outra parte que não o réu, ou que a autoridade devidamente capacitada tenha adotado medidas cautelares prolongando a suspensão da liberação dos bens, os bens serão liberados, desde que todas as outras condições para importação e exportação tenham sido cumpridas; em casos apropriados, esse limite de tempo pode ser estendido por 10 dias úteis adicionais. Se o processo tendente a uma decisão sobre o mérito do pedido tiver sido iniciado, haverá, quando solicitada pelo réu, uma revisão, inclusive o direito de ser ouvido, a fim de se decidir, dentro de um prazo razoável, se essas medidas serão modificadas, revogadas ou confirmadas. Não obstante o acima descrito, quando a suspensão da liberação dos bens for efetuada ou mantida de acordo com uma medida judicial cautelar, serão aplicadas as disposições do parágrafo 6 do Artigo 50.

Artigo 56. Indenização do Importador e do Proprietário dos Bens. As autoridades pertinentes terão o poder de determinar que o requerente pague ao importador, ao consignatário e ao proprietário dos bens uma compensação adequada por qualquer dano a eles causado pela retenção injusta dos bens ou pela retenção de bens liberados de acordo com o Artigo 55.

Artigo 57 Direito à Inspeção e à Informação Sem prejuízo da proteção de informações confidenciais, os Membros fornecerão às autoridades competentes o poder de conceder 
ao titular do direito oportunidade suficiente para que quaisquer bens detidos pelas autoridades alfandegárias sejam inspecionados, de forma a fundamentar as pretensões do titular do direito. As autoridades competentes terão também o poder de conceder ao importador uma oportunidade equivalente para que quaisquer desses bens sejam inspecionados. Quando a decisão de mérito for pela procedência do pedido, os Membros podem prover às autoridades competentes o poder de informar ao titular do direito os nomes e endereços do consignador, do importador e do consignatário e da quantidade dos bens em questão.

Artigo 58 - Ação Ex Officio. Quando os Membros exigem que as autoridades competentes atuem por conta própria e suspendam a liberação de bens em relação aos quais elas obtiveram prova inicial de que um direito de propriedade intelectual esteja sendo violado: (a) as autoridades competentes podem buscar obter, a qualquer momento, do titular do direito qualquer informação que possa assisti-las a exercer esse poder; (b) o importador e o titular do direito serão prontamente notificados da suspensão. Quando o importador tiver apresentado uma medida contra a suspensão junto às autoridades competentes, a suspensão estará sujeita, mutatis mutandis, às condições estabelecidas no Artigo 55; (c) os Membros só poderão isentar autoridades e servidores públicos de estarem sujeitos a medidas apropriadas de reparação quando os atos tiverem sido praticados ou pretendidos de boa fé.

Artigo 59 - Remédios. Sem prejuízo dos demais direitos de ação a que faz jus o titular do direito e ao direito do réu de buscar uma revisão por uma autoridade judicial, as autoridades competentes terão o poder de determinar a destruição ou a alienação de bens que violem direitos de propriedade intelectual, de acordo com os princípios estabelecidos no Artigo 46. Com relação a bens com marca contrafeita, as autoridades não permitirão sua reexportação sem que sejam alterados nem os submeterão a procedimento alfandegário distinto, a não ser em circunstâncias excepcionais.

Artigo 60 - Importações. De Minimis Os Membros poderão deixar de aplicar as disposições acima no caso de pequenas quantidades de bens, de natureza não-comercial, contidos na bagagem pessoal de viajantes ou enviados em pequenas consignações.

\section{SEÇÃO 5: PROCEDIMENTOS PENAIS}

Artigo 61 - Os Membros proverão a aplicação de procedimentos penais e penalidades pelo menos nos casos de contrafação voluntária de marcas e pirataria em escala comercial. Os remédios disponíveis incluirão prisão e/ou multas monetárias suficientes para constituir um fator de dissuasão, de forma compatível com o nível de penalidades aplicadas a crimes de gravidade correspondente. Em casos apropriados, os remédios disponíveis também incluirão a apreensão, perda e destruição dos bens que violem direitos de propriedade intelectual e de quaisquer materiais e implementos cujo uso predominante tenha sido na consecução do delito. Os Membros podem prover a aplicação de procedimentos penais e penalidades em outros casos de violação de direitos de propriedade intelectual, em especial quando eles forem cometidos voluntariamente e em escala comercial.

\section{PARTE IV - AQUISIÇÃO E MANUTENÇÃO DE DIREITOS DE PROPRIEDADE INTELECTUAL E PROCEDIMENTOS INTER-PARTES CONEXOS}

Artigo 62 - 1. Os Membros podem exigir o cumprimento de procedimentos e formalidades razoáveis, como uma condição da obtenção ou manutenção dos direitos de propriedade intelectual estabelecidos pelas Seções 2 a 6 da Parte II. Esses procedimentos e formalidades serão compatíveis com as disposições deste Acordo. 2. Quando a obtenção de um direito de propriedade intelectual estiver sujeita à concessão do direito ou a seu 
registro, os Membros, sem prejuízo do cumprimento dos requisitos substantivos para a obtenção dos direitos, assegurarão que os procedimentos para a concessão ou registro permitam a concessão ou registro do direito num prazo razoável, de modo a evitar redução indevida do prazo de proteção. 3. O Artigo 4 da Convenção de Paris (1967) será aplicado, mutatis mutandis, a marcas de serviço. 4. Os procedimentos relativos à obtenção ou manutenção de direitos de propriedade intelectual e, quando a legislação de um Membro os tiver, os relativos à nulidade administrativa e aos procedimentos inter-partes, como oposição, anulação e cancelamento, obedecerão os princípios gerais estabelecidos nos parágrafos 2 e 3 do Artigo 41. 5. As decisões administrativas finais em qualquer dos procedimentos previstos no Artigo 41 estará sujeita a revisão por uma autoridade judicial ou quase judicial. Não haverá obrigação, contudo, de prover uma oportunidade para essa revisão de decisões nos casos de oposição indeferida ou nulidade administrativa, desde que as razões para esses procedimentos possam estar sujeitas a procedimentos de invalidação.

\section{PARTE V PREVENÇÃO E SOLUÇÃO DE CONTROVÉRSIAS}

Artigo 63 - Transparência 1. As leis e regulamentos e as decisões judiciais e administrativas finais de aplicação geral, relativas à matéria objeto desse Acordo (existência, abrangência, obtenção, aplicação de normas de proteção e prevenção de abuso de direitos de propriedade intelectual) que forem colocados em vigor por um Membro serão publicadas ou, quando essa publicação não for conveniente, serão tornadas públicas, num idioma nacional, de modo a permitir que Governos e titulares de direitos delas tomem conhecimento. Os Acordos relativos a matéria objeto deste Acordo, que estejam em vigor entre o Governo ou uma Agência Governamental de um Membro e o Governo ou uma Agência Governamental de um outro Membro também serão publicados. 2. Os Membros notificarão o Conselho para TRIPS das leis e regulamentos a que se refere o parágrafo 1 , de forma a assistir aquele Conselho em sua revisão da operação deste Acordo. O Conselho tentará minimizar o ônus dos Membros em dar cumprimento a esta obrigação e pode decidir dispensá-los da obrigação de notificar diretamente o Conselho sobre tais leis e regulamentos se conseguir concluir com a OMPI entendimento sobre o estabelecimento de um registro comum contendo essas leis e regulamentos. Nesse sentido, o Conselho também considerará qualquer ação exigida a respeito das notificações originadas das obrigações deste Acordo derivadas das disposições do Artigo 6ter da Convenção de Paris (1967). 3. Cada Membro estará preparado a suprir informações do tipo referido no parágrafo 1, em resposta a um requerimento por escrito de outro Membro. Um Membro que tenha razão para acreditar que uma decisão judicial ou administrativa específica ou um determinado acordo bilateral na área de direitos de propriedade intelectual afete seus direitos, como previstos neste Acordo, também poderá requerer por escrito permissão de consultar ou de ser informado, com suficiente detalhe, dessas decisões judiciais ou administrativas específicas ou desse determinado acordo bilateral. 4. Nada do disposto nos parágrafos 1, 2 e 3 exigirá que os Membros divulguem informação confidencial que impediria a execução da lei ou que seria contrária ao interesse público ou que prejudicaria os interesses comerciais legítimos de determinadas empresas, públicas ou privadas.

Artigo 64 - Solução de Controvérsias 1. O disposto nos Artigos XXII e XXIII do GATT 1994, como elaborado e aplicado pelo Entendimento de Solução e Controvérsias, será aplicado a consultas e soluções de controvérsias no contexto desse Acordo, salvo disposição contrária especificamente prevista neste Acordo. 2. Os subparágrafos 1(b) e 1(c) do Artigo XXIII do GATT 1994 não serão aplicados a soluções de controvérsias no contexto deste Acordo durante um prazo de cinco anos contados a partir da data de entrada 
em vigor do Acordo Constitutivo da OMC. 3. Durante o prazo a que se refere o parágrafo 2, o Conselho para TRIPS examinará a abrangência e as modalidades para reclamações do tipo previsto nos subparágrafos 1(b) e 1(c) do Artigo XXIII do GATT 1994, efetuadas em conformidade com este Acordo, e submeterão suas recomendações à Conferência Ministerial para aprovação. Qualquer decisão da Conferência Ministerial de aprovar essas recomendações ou de estender o prazo estipulado no parágrafo 2 somente será adotada por consenso. As recomendações aprovadas passarão a vigorar para todos os Membros sem qualquer processo formal de aceitação.

\section{PARTE VI DISPOSIÇÕES TRANSITÓRIAS}

Artigo 65 - Disposições Transitórias 1. Sem prejuízo do disposto nos parágrafos 2, 3 e 4, nenhum Membro estará obrigado a aplicar as disposições do presente Acordo antes de transcorrido um prazo geral de um ano após a data de entrada em vigor do Acordo Constitutivo da OMC. 2. Um País em desenvolvimento Membro tem direito a postergar a data de aplicação das disposições do presente Acordo, estabelecida no parágrafo 1, por um prazo de quatro anos, com exceção dos Artigos 3, 4 e 5. 3. Qualquer outro Membro que esteja em processo de transformação de uma economia de planejamento centralizado para uma de mercado e de livre empresa e esteja realizando uma reforma estrutural de seu sistema de propriedade intelectual e enfrentando problemas especiais na preparação e implementação de leis e regulamentos de propriedade intelectual, poderá também beneficiar-se de um prazo de adiamento tal como previsto no parágrafo 2. 4. Na medida em que um País em desenvolvimento Membro esteja obrigado pelo presente Acordo a estender proteção patentária de produtos a setores tecnológicos que não protegia em seu território na data geral de aplicação do presente Acordo, conforme estabelecido no parágrafo 2, ele poderá adiar a aplicação das disposições sobre patentes de produtos da Seção 5 da Parte II para tais setores tecnológicos por um prazo adicional de cinco anos. 5. Um Membro que se utilize do prazo de transição previsto nos parágrafos $1,2,3$ e 4 assegurará que quaisquer modificações nas suas legislações, regulamentos e prática feitas durante esse prazo não resultem em um menor grau de consistência com as disposições do presente Acordo.

Artigo 66 - Países de Menor Desenvolvimento Relativo Membros 1. Em virtude de suas necessidades e requisitos especiais, de suas limitações econômicas, financeiras e administrativas e de sua necessidade de flexibilidade para estabelecer uma base tecnológica viável, os países de menor desenvolvimento relativo Membros não estarão obrigados a aplicar as disposições do presente Acordo, com exceção dos Artigos 3, 4 e 5, durante um prazo de dez anos contados a partir da data de aplicação estabelecida no parágrafo 1 do Artigo 65. O Conselho para TRIPS, quando receber um pedido devidamente fundamentado de um país de menor desenvolvimento relativo Membro, concederá prorrogações desse prazo. 2. Os países desenvolvidos Membros concederão incentivos a empresas e instituições de seus territórios com o objetivo de promover e estimular a transferência de tecnologia aos países de menor desenvolvimento relativo Membros, a fim de habilitá-los a estabelecer uma base tecnológica sólida e viável.

Artigo 67 - Cooperação Técnica A fim de facilitar a aplicação do presente Acordo, os países desenvolvidos Membros, a pedido, e em termos e condições mutuamente acordadas, prestarão cooperação técnica e financeira aos países em desenvolvimento Membros e de menor desenvolvimento relativo Membros. Essa cooperação incluirá assistência na elaboração de leis e regulamentos sobre proteção e aplicação de normas de proteção dos direitos de propriedade intelectual bem como sobre a prevenção de seu abuso, e incluirá apoio ao estabelecimento e fortalecimento dos escritórios e agências nacionais competentes nesses assuntos, inclusive na formação de pessoal. 


\section{PARTE VII DISPOSIÇÕES INSTITUCIONAIS DISPOSIÇÕES FINAIS}

Artigo 68 - Conselho dos Aspectos dos Direitos de Propriedade Intelectual Relacionados ao Comércio O Conselho para TRIPS supervisionará a aplicação deste Acordo e, em particular, o cumprimento, por parte dos Membros, das obrigações por ele estabelecidas, e lhes oferecerá a oportunidade de efetuar consultas sobre questões relativas aos aspectos dos direitos de propriedade intelectual relacionados ao comércio. O Conselho se desincumbirá de outras atribuições que lhe forem confiadas pelos Membros e, em particular, lhes prestará qualquer assistência solicitada no contexto de procedimentos de solução de controvérsias. No desempenho de suas funções, o Conselho para TRIPS poderá consultar e buscar informações de qualquer fonte que considerar adequada. Em consulta com a OMPI, o Conselho deverá buscar estabelecer, no prazo de um ano a partir de sua primeira reunião, os arranjos apropriados para a cooperação com os órgãos daquela Organização.

Artigo 69 - Cooperação Internacional Os Membros concordam em cooperar entre si com o objetivo de eliminar o comércio internacional de bens que violem direitos de propriedade intelectual. Para este fim, estabelecerão pontos de contato em suas respectivas administrações nacionais, deles darão notificação e estarão prontos a intercambiar informações sobre o comércio de bens infratores. Promoverão, em particular, o intercâmbio de informações e a cooperação entre as autoridades alfandegárias no que tange ao comércio de bens com marca contrafeita e bens pirateados. Artigo 70 - Proteção da Matéria Existente 1. Este Acordo não gera obrigações relativas a atos ocorridos antes de sua data de aplicação para o respectivo Membro. 2. Salvo disposição em contrário nele prevista, este Acordo, na data de sua aplicação para o Membro em questão, gera obrigações com respeito a toda a matéria existente, que esteja protegida naquele Membro na citada data, ou que satisfaça, ou venha posteriormente a satisfazer, os critérios de proteção estabelecidos neste Acordo. Com relação ao presente parágrafo e aos parágrafos 3 e 4 abaixo, as obrigações em matéria de direito do autor relacionadas com obras existentes serão determinadas unicamente pelo disposto no Artigo 18 da Convenção de Berna (1971), e as obrigações relacionadas com os direitos dos produtores de fonogramas e dos artistas-intérpretes em fonogramas existentes serão determinadas unicamente pelo disposto no Artigo 18 da Convenção de Berna (1971), na forma em que foi tornado aplicável pelo disposto no parágrafo 6 do Artigo 14 deste Acordo. 3. Não haverá obrigação de restabelecer proteção da matéria, que, na data de aplicação deste Acordo para o Membro em questão, tenha caído no domínio público. 4. Com respeito a quaisquer atos relativos a objetos específicos que incorporem matéria protegida e que venham a violar direitos de propriedade intelectual, nos termos de legislação em conformidade com este Acordo, e que se tenham iniciado, ou para os quais o investimento significativo tenha sido efetuado, antes da data de aceitação do Acordo Constitutivo da OMC por aquele Membro, qualquer Membro poderá estabelecer uma limitação aos remédios disponíveis ao titular de direito com relação à continuação desses atos após a data de aplicação deste Acordo por aquele Membro. Em tais casos, entretanto, o Membro estabelecerá ao menos o pagamento de remuneração eqüitativa. 5. Nenhum Membro está obrigado a aplicar as disposições do Artigo 11 nem do parágrafo 4 do Artigo 14 a originais ou cópias compradas antes da data de aplicação deste Acordo para este Membro. 6. Os Membros não estão obrigados a aplicar o Artigo 31, nem o requisito estabelecido no parágrafo 1 do Artigo 27 segundo o qual os direitos de patente serão desfrutados sem discriminação quanto ao setor tecnológico, no tocante ao uso sem a autorização do titular do direito, quando a autorização para tal uso tenha sido concedida 
pelo Governo antes da data em que este Acordo tornou-se conhecido. 7. No caso de direitos de propriedade intelectual para os quais a proteção esteja condicionada ao registro, será permitido modificar solicitações de proteção que se encontrem pendentes na data de aplicação deste Acordo para o Membro em questão, com vistas a reivindicar qualquer proteção adicional prevista nas disposições deste Acordo. Tais modificações não incluirão matéria nova. 8. Quando um Membro, na data de entrada em vigor do Acordo Constitutivo da OMC, não conceder proteção patentária a produtos farmacêuticos nem aos produtos químicos para a agricultura em conformidade com as obrigações previstas no Artigo 27, esse Membro: (a) não obstante as disposições da Parte VI, estabelecerá, a partir da data de entrada em vigor do Acordo Constitutivo da OMC, um meio pelo qual os pedidos de patente para essas invenções possam ser depositados; (b) aplicará a essas solicitações, a partir da data de aplicação deste Acordo, os critérios de patentabilidade estabelecidos neste instrumento como se tais critérios estivessem sendo aplicados nesse Membro na data do depósito dos pedidos, quando uma prioridade possa ser obtida e seja reivindicada, na data de prioridade do pedido; e (c) estabelecerá proteção patentária, em conformidade com este Acordo, a partir da concessão da patente e durante o resto da duração da mesma, a contar da data de apresentação da solicitação em conformidade com o Artigo 33 deste Acordo, para as solicitações que cumpram os critérios de proteção referidos na alínea (b) acima. 9. Quando um produto for objeto de uma solicitação de patente num Membro, em conformidade com o parágrafo 8(a), serão concedidos direitos exclusivos de comercialização, não obstante as disposições da Parte VI acima, por um prazo de cinco anos, contados a partir da obtenção da aprovação de comercialização nesse Membro ou até que se conceda ou indefira uma patente de produto nesse Membro se esse prazo for mais breve, desde que, posteriormente à data de entrada em vigor do Acordo Constitutivo da OMC, uma solicitação de patente tenha sido apresentada e uma patente concedida para aquele produto em outro Membro e se tenha obtido a aprovação de comercialização naquele outro Membro.

Artigo 71 - Revisão e Emenda 1. O Conselho para TRIPS avaliará a aplicação deste Acordo após transcorrido o prazo de transição mencionado no parágrafo 2 do Artigo 65. Com base na experiência adquirida em sua aplicação, o Conselho empreenderá uma revisão do Acordo dois anos após aquela data e, subseqüentemente, em intervalos idênticos. O Conselho poderá também efetuar avaliações à luz de quaisquer acontecimentos novos e relevantes, que possam justificar modificação ou emenda deste Acordo. 2. As emendas que sirvam meramente para incorporar níveis mais elevados de proteção dos direitos de propriedade intelectual, alcançados e vigentes em outros acordos multilaterais, e que tenham sido aceitos no contexto desses acordos por todos os Membros da OMC, poderão ser encaminhados à Conferência Ministerial para sua deliberação, em conformidade com o disposto no parágrafo 6 do Artigo X do Acordo Constitutivo da OMC, a partir de uma proposta consensual do Conselho de TRIPS.

Artigo 72 - Reservas. Não poderão ser feitas reservas com relação a qualquer disposição deste Acordo sem o consentimento dos demais Membros.

Artigo 73 - Exceções de Segurança. Nada neste Acordo será interpretado: (a) como exigência de que um Membro forneça qualquer informação, cuja divulgação ele considere contrária a seus interesses essenciais de segurança; ou (b) como impeditivo de que um Membro adote qualquer ação que considere necessária para a proteção de seus interesses essenciais de segurança: (i) relativos a materiais físseis ou àqueles dos quais são derivados; (ii) relativos ao tráfico de armas, munição e material bélico e ao tráfico de outros bens e materiais efetuado, direta ou indiretamente, com o propósito de suprir estabelecimentos militares; (iii) adotada em tempo de guerra ou de outra emergência em relações internacionais; ou (c) como impeditivo de um Membro adotar qualquer ação de 
acordo com a Carta das Nações Unidas para a manutenção da paz e segurança internacionais. ADVERTÊNCIA: Este texto não substitui o texto oficial publicado no Diário Oficial da União no 248-A, de 31 de dezembro de 1994, seção 1, páginas 93 a 103. NOTAS AO TEXTO OFICIAL DO ACORDO TRIPS (OU ACORDO ADPIC) PUBLICADO NO SUPLEMENTO AO DIÁRIO OFICIAL No 248-A, DE 31 DE DEZEMBRO DE 1994: (a) Os elementos do texto oficial do Acordo TRIPS (ou Acordo ADPIC), incluindo as notas de rodapé, sofreram mudanças de localização e de disposição nesta transcrição, a fim de facilitar a leitura do texto. (b) A nota de rodapé no 1 talvez merecesse a introdução da palavra "de" entre "(...) separado" e "Membro (...)", de tal forma que a parte do texto passasse a ter a seguinte leitura: "(...) no caso de um território aduaneiro separado de Membro da OMC (...)". (c) A palavra "nacional" do título do Artigo 3 teve sua primeira letra transcrita em maiúscula, por motivo de harmonização de texto. (d) No Artigo 20, a palavra "outro", no trecho "(...) os bens e serviços de uma empresa daqueles de outro empresa. (...)", foi trocada por "outra". (e) A palavra "Geográficas", segunda palavra do parágrafo 1 do Artigo 22, teve sua primeira letra transcrita em minúscula, por motivo de harmonização de texto. (f) No parágrafo 3 do Artigo 22, foi acrescentada uma vírgula (“,”) entre “(...) de uma parte interessada" e "o registro de uma marca (...)". (g) As duas primeiras palavras da nota de rodapé no 7 foram colocadas no singular, ou seja, foi trocado "Os termos (...)" por "O termo (...)". (h) O artigo definido "O" no início do Artigo 30 foi colocado no plural. (i) Na última parte do Artigo 46, a vírgula (“,”) do trecho “(...). Na consideração desses, pedidos será (...)” foi transposta para depois da palavra "pedidos", de tal forma que o trecho passou a ser: "(...). Na consideração desses pedidos, será (...)". (j) No fím do título da Seção 4, foi acrescentado o indicador de nota de rodapé no 12 omitido no texto oficial. (k) O título da Parte VII teve o sinal de dois pontos (“:”) trocado por um de ponto e vírgula (“;”). (1) A palavra "segurança" do título do Artigo 73 teve sua primeira letra transcrita em maiúscula, por motivo de harmonização de texto.

\section{Anexo II}

A Classificação Internacional de Produtos e Serviços para o Registro de Marcas instituída por Acordo concluído por ocasião da Conferência Diplomática de Nice, em 15 de junho de 1957, e revista em Estocolmo, em 1967, e em Genebra, em 1977, e corrigida em 1979.

\begin{tabular}{|l|l|}
\hline PRODUTOS & $\mid$ \\
\hline Classe 1 & $\begin{array}{l}\text { Substâncias químicas destinadas à } \\
\text { indústria, às ciências, à fotografia, assim }\end{array}$ \\
& $\begin{array}{l}\text { como à agricultura, à horticultura e à } \\
\text { silvicultura; resinas artificiais não- }\end{array}$ \\
\hline
\end{tabular}




\begin{tabular}{|c|c|}
\hline & $\begin{array}{l}\text { processadas, matérias plásticas não } \\
\text { processadas; adubo; composições } \\
\text { extintoras de fogo; preparações para } \\
\text { temperar e soldar; substâncias químicas } \\
\text { destinadas a conservar alimentos; } \\
\text { substâncias tanantes; substâncias adesivas } \\
\text { destinados à indústria. }\end{array}$ \\
\hline Classe 2 & $\begin{array}{l}\text { Tintas, vernizes, lacas; preservativos } \\
\text { contra oxidação e contra deterioração da } \\
\text { madeira; matérias tintoriais; mordentes; } \\
\text { resinas naturais em estado bruto; metais } \\
\text { em folhas e em pó para pintores, } \\
\text { decoradores, impressores e artistas. }\end{array}$ \\
\hline Classe 3 & $\begin{array}{l}\text { Preparações para branquear e outras } \\
\text { substâncias para uso em lavanderia; } \\
\text { produtos para limpar, polir e decapar; } \\
\text { produtos abrasivos; sabões; perfumaria, } \\
\text { óleos essenciais, cosméticos, loções para } \\
\text { os cabelos; dentífricos }\end{array}$ \\
\hline Classe 4 & $\begin{array}{l}\text { Graxas e óleos industriais; lubrificantes; } \\
\text { produtos para absorver, molhar e ligar pó; } \\
\text { combustíveis (incluindo gasolina para } \\
\text { motores) e materiais para iluminação; } \\
\text { velas e pavios para iluminação. }\end{array}$ \\
\hline Classe 5 & $\begin{array}{l}\text { Preparações farmacêuticas e veterinárias; } \\
\text { preparações higiênicas para uso } \\
\text { medicinal; substâncias dietéticas } \\
\text { adaptadas para uso medicinal, alimentos } \\
\text { para bebês; emplastros, materiais para } \\
\text { curativos; material para obturações } \\
\text { dentárias, cera dentária; desinfetantes; } \\
\text { preparações para destruição de vermes; } \\
\text { fungicidas, herbicidas. }\end{array}$ \\
\hline Classe 6 & $\begin{array}{l}\text { Metais comuns e suas ligas; materiais de } \\
\text { metal para construção; construções } \\
\text { transportáveis de metal; materiais de metal } \\
\text { para vias férreas; cabos e fios de metal } \\
\text { comum não elétricos; serralheria, } \\
\text { pequenos artigos de ferragem; canos e } \\
\text { tubos de metal; cofres; produtos de metal } \\
\text { comum não incluídos em outras Classes; } \\
\text { minérios }\end{array}$ \\
\hline Classe 7 & $\begin{array}{l}\text { Máquinas e ferramentas mecânicas; } \\
\text { motores (exceto para veículos terrestres); }\end{array}$ \\
\hline
\end{tabular}




\begin{tabular}{|c|c|}
\hline & $\begin{array}{l}\text { e engates de máquinas e componentes de } \\
\text { transmissão (exceto para veículos } \\
\text { terrestres); instrumentos agrícolas não } \\
\text { manuais; chocadeiras }\end{array}$ \\
\hline Classe 8 & $\begin{array}{l}\text { Ferramentas e instrumentos manuais } \\
\text { (propulsão muscular); cutelaria; armas } \\
\text { brancas; aparelhos de barbear. }\end{array}$ \\
\hline Classe 9 & $\begin{array}{l}\text { Aparelhos e instrumentos científicos, } \\
\text { náuticos, geodésicos, fotográficos, } \\
\text { cinematográficos, ópticos, de pesagem, de } \\
\text { medição, de sinalização, de controle } \\
\text { (inspeção), de salvamento e de ensino; } \\
\text { aparelhos e instrumentos para conduzir, } \\
\text { interromper, transformar, acumular, } \\
\text { regular ou controlar eletricidade; } \\
\text { aparelhos para registrar, transmitir ou } \\
\text { reproduzir som ou imagens; suporte de } \\
\text { registro magnético, discos acústicos; } \\
\text { máquinas distribuidoras automáticas e } \\
\text { mecanismos para aparelhos operados com } \\
\text { moedas; caixas registradoras, máquinas de } \\
\text { calcular, equipamento de processamento } \\
\text { de dados e computadores; aparelhos } \\
\text { extintores de incêndio. }\end{array}$ \\
\hline Classe 10 & $\begin{array}{l}\text { Aparelhos e instrumentos cirúrgicos, } \\
\text { médicos, odontológicos e veterinários, } \\
\text { membros, olhos e dentes artificiais; } \\
\text { artigos ortopédicos; material de sutura. }\end{array}$ \\
\hline Classe 11 & $\begin{array}{l}\text { Aparelhos para iluminação, aquecimento, } \\
\text { produção de vapor, cozinhar, refrigeração, } \\
\text { secagem, ventilação, fornecimento de } \\
\text { água e para fins sanitários. }\end{array}$ \\
\hline Classe 12 & $\begin{array}{l}\text { Veículos; aparelhos para locomoção por } \\
\text { terra, ar ou água. }\end{array}$ \\
\hline Classe 13 & $\begin{array}{l}\text { Armas de fogo; munições e projéteis; } \\
\text { explosivos; fogos de artifício }\end{array}$ \\
\hline Classe 14 & $\begin{array}{l}\text { Metais preciosos e suas ligas e produtos } \\
\text { nessas matérias ou folheados, não } \\
\text { incluídos em outras Classes; jóias, } \\
\text { bijuteria, pedras preciosas; relojoaria e } \\
\text { instrumentos cronométricos. }\end{array}$ \\
\hline Classe 15 & Instrumentos musicais \\
\hline Classe 16 & $\begin{array}{l}\text { Papel, papelão e produtos feitos desses } \\
\text { materiais e não incluídos em outras }\end{array}$ \\
\hline
\end{tabular}




\begin{tabular}{|c|c|}
\hline & $\begin{array}{l}\text { classes; material impresso; artigos para } \\
\text { encadernação; fotografias; papelaria; } \\
\text { adesivos para papelaria ou uso doméstico; } \\
\text { materiais para artistas; pincéis; máquinas } \\
\text { de escrever e material de escritório (exceto } \\
\text { móveis); material de instrução e didático } \\
\text { (exceto aparelhos); matérias plásticas para } \\
\text { embalagem (não incluídas em outras } \\
\text { Classes); caracteres de imprensa; clichês }\end{array}$ \\
\hline Classe 17 & $\begin{array}{l}\text { Borracha, guta-percha, goma, amianto, } \\
\text { mica e produtos feitos com estes materiais } \\
\text { e não incluídos em outras Classes; } \\
\text { produtos em matérias plásticas } \\
\text { semiprocessadas; materiais para calafetar, } \\
\text { vedar e isolar; canos flexíveis, não } \\
\text { metálicos. }\end{array}$ \\
\hline Classe 18 & $\begin{array}{l}\text { Couro e imitações de couros, produtos } \\
\text { nessas matérias não incluídos em outras } \\
\text { classes; peles de animais; malas e bolsas } \\
\text { de viagem; guarda-chuvas, guarda-sóis e } \\
\text { bengalas; chicotes, arreios e selaria. }\end{array}$ \\
\hline Classe 19 & $\begin{array}{l}\text { Materiais de construção (não metálicos); } \\
\text { canos rígidos não metálicos para } \\
\text { construção; asfalto, piche e betume; } \\
\text { construções transportáveis não metálicas; } \\
\text { monumentos não metálicos. }\end{array}$ \\
\hline Classe 20 & $\begin{array}{l}\text { Móveis, espelhos, molduras; produtos } \\
\text { (não incluídos em outras Classes), de } \\
\text { madeira, cortiça, junco, cana, vime, chifre, } \\
\text { marfim, osso, barbatana de baleia, concha, } \\
\text { tartaruga, âmbar, madrepérola, espuma- } \\
\text { do-mar e sucedâneos de todas estas } \\
\text { matérias ou de matérias plásticas. }\end{array}$ \\
\hline Classe 21 & $\begin{array}{l}\text { Utensílios e recipientes para a casa ou } \\
\text { cozinha (não de metal precioso ou } \\
\text { folheado); pentes e esponjas; escovas } \\
\text { (exceto para pintura); materiais para } \\
\text { fabricação de escovas; materiais de } \\
\text { limpeza; palha de aço; vidro não } \\
\text { trabalhado ou semitrabalhado (exceto para } \\
\text { construção); artigos de vidro, porcelana e } \\
\text { louça de faiança não incluídos em outras } \\
\text { classes. }\end{array}$ \\
\hline Classe 22 & $\begin{array}{l}\text { Cordas, fios, redes, tendas, toldos, } \\
\text { oleados, velas, sacos, sacolas (não } \\
\text { incluídos em outras Classes); matérias de }\end{array}$ \\
\hline
\end{tabular}




\begin{tabular}{|c|c|}
\hline & $\begin{array}{l}\text { enchimento (exceto borrachas e plásticos); } \\
\text { matérias têxteis fibrosas em bruto. }\end{array}$ \\
\hline Classe 23 & Fios para uso têxtil \\
\hline Classe 24 & $\begin{array}{l}\text { Tecidos e produtos têxteis, não incluídos } \\
\text { em outras Classes; coberturas de cama e } \\
\text { mesa. }\end{array}$ \\
\hline Classe 25 & Vestuário, calçados e chapelaria. \\
\hline Classe 26 & $\begin{array}{l}\text { Rendas e bordados, fitas e laços; botões, } \\
\text { colchetes e ilhós, alfinetes e agulhas; } \\
\text { flores artificiais. }\end{array}$ \\
\hline Classe 27 & $\begin{array}{l}\text { Carpetes, tapetes, capachos e esteiras, } \\
\text { linóleo e outros revestimentos de } \\
\text { assoalhos; colgaduras que não sejam em } \\
\text { matérias têxteis. }\end{array}$ \\
\hline Classe 28 & $\begin{array}{l}\text { Jogos e brinquedos; artigos para ginástica } \\
\text { e esporte não incluídos em outras classes; } \\
\text { decorações para árvores de Natal. }\end{array}$ \\
\hline Classe 29 & $\begin{array}{l}\text { Carne, peixe, aves e caça; extratos de } \\
\text { carne; frutas, legumes e verduras em } \\
\text { conserva, secos e cozidos; geleias, doces e } \\
\text { compotas; ovos, leite e laticínio; óleos e } \\
\text { gorduras comestíveis. }\end{array}$ \\
\hline Classe 30 & $\begin{array}{l}\text { Café, chá, cacau, açúcar, arroz, tapioca, } \\
\text { sagu, sucedâneos de café; farinhas e } \\
\text { preparações feitas de cereais, pão, massas } \\
\text { e confeitos, sorvetes; mel, xarope de } \\
\text { melaço; lêvedo, fermento em pó; sal, } \\
\text { mostarda; vinagre, molhos (condimentos); } \\
\text { especiarias; gelo }\end{array}$ \\
\hline Classe 31 & $\begin{array}{l}\text { Produtos agrícolas, hortícolas, florestais e } \\
\text { grãos não incluídos em outras classes; } \\
\text { animais vivos; frutas, legumes e verduras } \\
\text { frescos; sementes, plantas e flores } \\
\text { naturais; alimentos para animais, malte. }\end{array}$ \\
\hline Classe 32 & $\begin{array}{l}\text { Cervejas; águas minerais e gasosas e } \\
\text { outras bebidas não alcoólicas; bebidas de } \\
\text { frutas e sucos de fruta; xaropes e outras } \\
\text { preparações para fabricar bebidas. }\end{array}$ \\
\hline
\end{tabular}




\begin{tabular}{|c|c|}
\hline Classe 33 & Bebidas alcoólicas (exceto cervejas). \\
\hline Classe 34 & Tabaco; artigos para fumantes; fósforos. \\
\hline \multicolumn{2}{|l|}{ SERVIÇOS } \\
\hline Classe 35 & $\begin{array}{l}\text { Propaganda; gestão de negócios; } \\
\text { administração de negócios; funções de } \\
\text { escritório. }\end{array}$ \\
\hline Classe 36 & $\begin{array}{l}\text { Seguros; negócios financeiros; negócios } \\
\text { monetários; negócios imobiliários. }\end{array}$ \\
\hline Classe 37 & $\begin{array}{l}\text { Construção civil; reparos; serviços de } \\
\text { instalação }\end{array}$ \\
\hline Classe 38 & Telecomunicações \\
\hline Classe 39 & $\begin{array}{l}\text { Transporte; embalagem e armazenagem } \\
\text { de produtos; organização de viagens. }\end{array}$ \\
\hline Classe 40 & Tratamento de materiais. \\
\hline Classe 41 & $\begin{array}{l}\text { Educação, provimento de treinamento; } \\
\text { entretenimento; atividades desportivas e } \\
\text { culturais. }\end{array}$ \\
\hline Classe 42 & $\begin{array}{l}\text { Serviços científicos e tecnológicos, } \\
\text { pesquisa e desenho relacionados a estes; } \\
\text { serviços de análise industrial e pesquisa; } \\
\text { concepção, projeto e desenvolvimento de } \\
\text { hardware e software de computador; } \\
\text { serviços jurídicos. }\end{array}$ \\
\hline Classe 43 & $\begin{array}{l}\text { Serviços de fornecimento de comida e } \\
\text { bebida; acomodações temporárias }\end{array}$ \\
\hline Classe 44 & $\begin{array}{l}\text { Serviços médicos; serviços veterinários; } \\
\text { serviços de higiene e beleza para seres } \\
\text { humanos ou animais; serviços de } \\
\text { agricultura, de horticultura e de } \\
\text { silvicultura }\end{array}$ \\
\hline Classe 45 & $\begin{array}{l}\text { Serviços pessoais e sociais prestados por } \\
\text { terceiros, para satisfazer necessidades de } \\
\text { indivíduos; serviços de segurança para } \\
\text { proteção de bens e pessoas. }\end{array}$ \\
\hline
\end{tabular}

